\title{
SEASONAL VARIATION OF MILK IN CENTRAL VALLEY CALIFORNIA AND THE ASSOCIATION OF MILK VARAITION WITH THE COMPOSITION AND TEXTURE OF LOW MOISTURE PART SKIM MOZZARELLA
}

\author{
A Thesis \\ presented to \\ the Faculty of California Polytechnic State University, \\ San Luis Obispo
}

In Partial Fulfillment of the Requirements for the Degree Master of Science in Agriculture, with Specialization in Dairy Products Technology

By

Vaideki Jai,

December, 2014 
(C)2014

Vaideki Jai

ALL RIGHTS RESERVED 
TITLE:

Seasonal Variation of Milk in Central Valley California and the Association between Milk Composition and the Chemical Composition and Texture of Low Moisture Part Skim Mozzarella
AUTHOR:
Vaideki Jai

DATE SUBMITTED: December 2014

COMMITTEE CHAIR: $\quad$ Rafael Jiménez-Flores, Ph.D., Professor of Dairy Products Technology California Polytechnic State University, San Luis Obispo, California.

COMMITTEE MEMBER: Ulric J. Lund, Ph.D., Professor of Statistics, California Polytechnic State University, San Luis Obispo, CA.

COMMITTEE MEMBER: Amy Lammert, Ph.D., Assistant Professor of Food Science and Nutrition, California Polytechnic State University, San Luis Obispo, CA. 


\begin{abstract}
Seasonal Variation of Milk in Central Valley California and the Association between Milk Composition and the Chemical Composition and Texture of Low Moisture Part Skim Mozzarella
\end{abstract}

\title{
Vaideki Jai
}

The chemical composition of milk (specifically casein, fat, and calcium) is known to affect the quality and functional properties of Mozzarella cheese. Therefore, concentrations of total nitrogen, casein nitrogen, non-casein nitrogen, non-protein nitrogen, true nitrogen, casein nitrogen to total nitrogen ratio, casein nitrogen to true nitrogen ratio, fat, total calcium, total solids, somatic cells, and $\mathrm{pH}$ were measured in silo milk samples collected weekly over 18-months from a large dairy plant in Central Valley, California from July 2008 to December 2009 to verify changes and correlate to low moisture part skim Mozzarella (LMPS) characteristics. LMPS mozzarella cheese from the same plant was also collected biweekly during the same period and analyzed five days post manufacture for total nitrogen, water soluble nitrogen, total calcium, water soluble calcium, salt, $\mathrm{pH}$, fat in dry matter and total solids and texture properties (i.e., hardness (g), cohesiveness, springiness, chewiness (g), aggregation index (AGI), and percentage cheese loss during shredding). Significant seasonal variations of total nitrogen, non-protein nitrogen, casein nitrogen, casein nitrogen to total nitrogen ratio, casein nitrogen to true nitrogen ratio, and total calcium in milk were explained using a linear model equivalent to a basic single cosinor model with sine and cosine of week (converted into radians) as predictors. Correlation studies were done between milk composition and cheese composition, milk composition and cheese textural characteristics as well as cheese composition and cheese texture, showing that 
concentration of total calcium and nitrogen fractions in cheese milk significantly affected the texture and composition of LMPS mozzarella. Also, the cheese total nitrogen, total calcium and water soluble calcium affected the cheese texture. The LMPS Mozzarella that was firmer and more cohesive had less loss during shredding and aggregated to a lesser extent. The milk total nitrogen, non-protein nitrogen, casein nitrogen, casein to total protein ratio, casein to true protein ratio, and total calcium had positive correlation with each other. However, the milk non-casein nitrogen did not significantly correlate with other nitrogen fractions and total calcium of milk. In addition, there was a significant increase of water soluble nitrogen, percent loss in shredding and aggregation index, and a significant decrease of hardness, and chewiness of LMPS Mozzarella ripened at $8.9^{0} \mathrm{C}$ in comparison to the cheese ripened at $3.3^{0} \mathrm{C}$ for 21 days.

Keywords: Seasonal variation, milk composition in California, Low Moisture Part Skim (LMPS) Mozzarella, LMPS Mozzarella chemical composition, LMPS Mozzarella texture characteristics, ripening study of LMPS Mozzarella 


\section{TABLE OF CONTENTS}

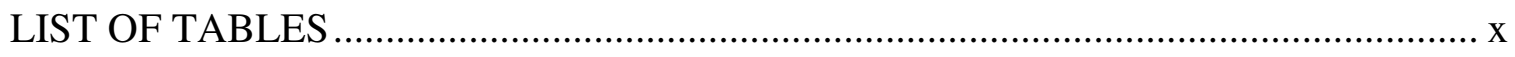

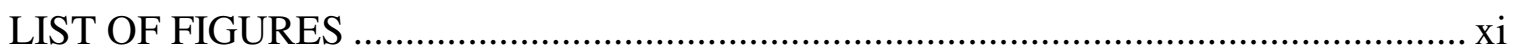

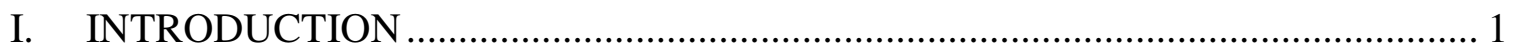

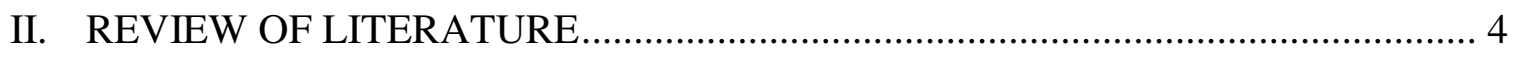

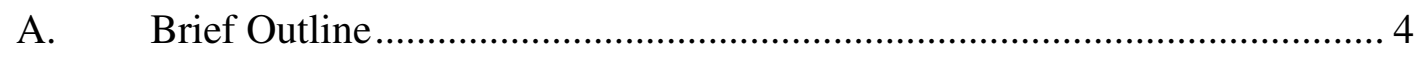

B. Milk Composition................................................................................... 4

C. Quality of Milk affecting Cheese Quality ……………………………...... 5

1. Somatic Cell Count (SCC) ………………………………………..... 5

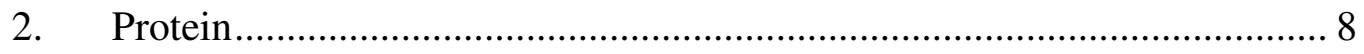

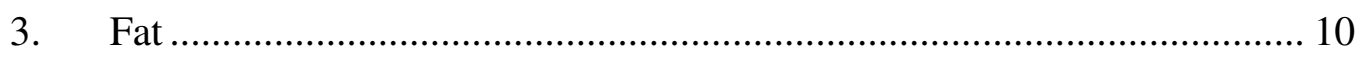

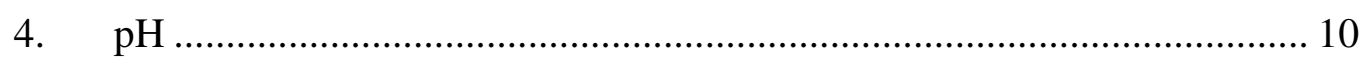

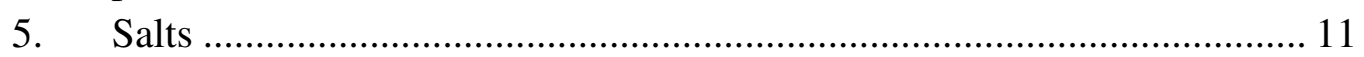

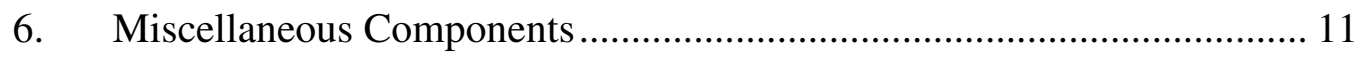

7. Milk Components and Cheese Making ……………………………….... 12

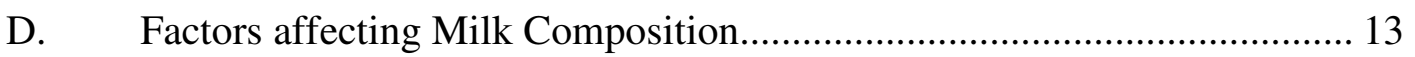

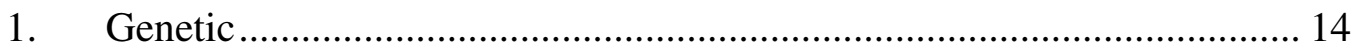

2. Interval between Milkings ................................................................... 15

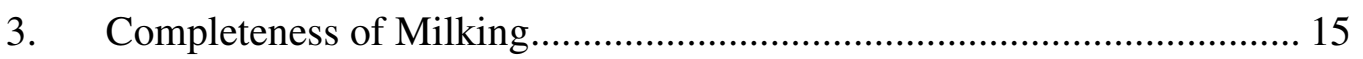

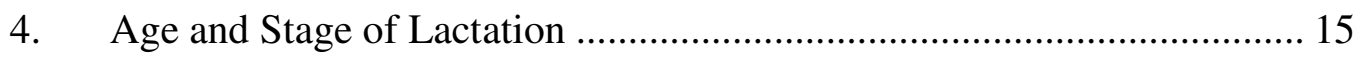

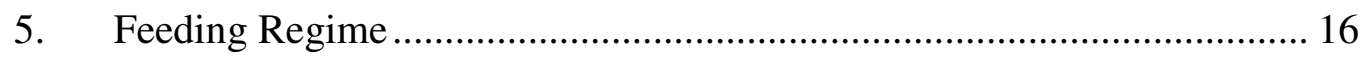

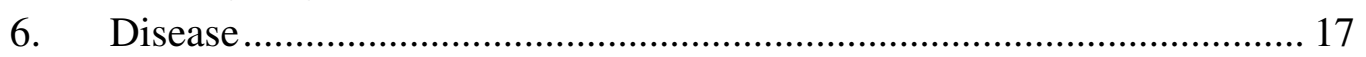

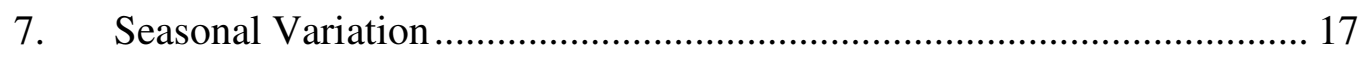

7a. Studies on Seasonal Variation of Milk Composition.......................... 18

7b. Studies on Seasonal Variation of MIlk Composition in

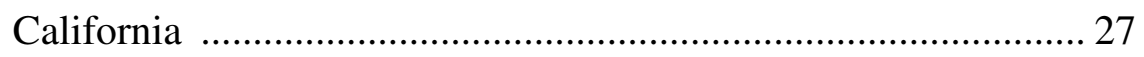

E. Low Moisture Part Skim (LMPS) Mozzarella .............................................. 31

F. Manufacturing of Low Moisture Part Skim (LMPS) Mozzarella ............... 32

G. Characteristics of LMPS Mozzarella Cheese Structure ………………...... 38

H. Functional Properties of LMPS Mozzarella ................................................. 42

1. Shreddability and Matting Behavior....................................................... 42

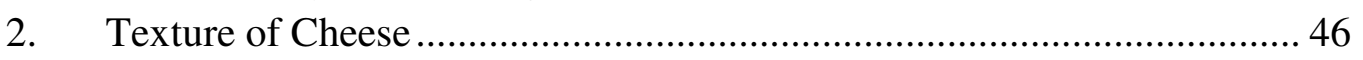

I. Proteolysis and Ageing of Cheese .......................................................... 48

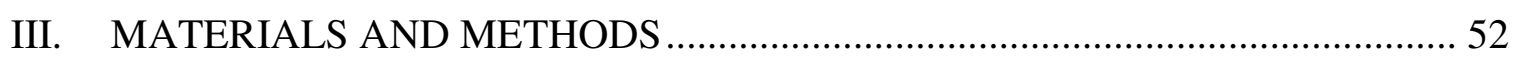

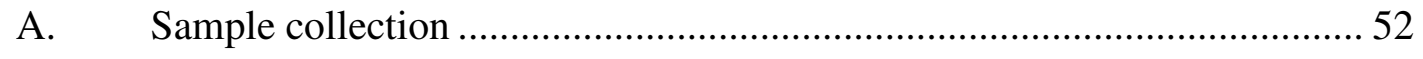




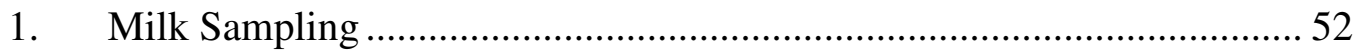

2. Low moisture part skim mozzarella (LMPS) sampling............................ 53

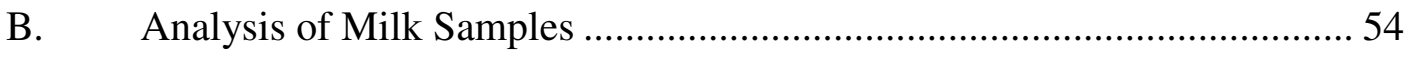

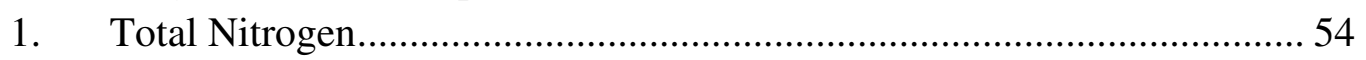

2. Non- protein Nitrogen (NPN) ........................................................... 54

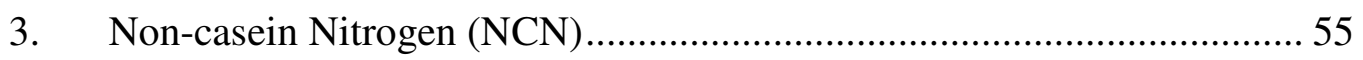

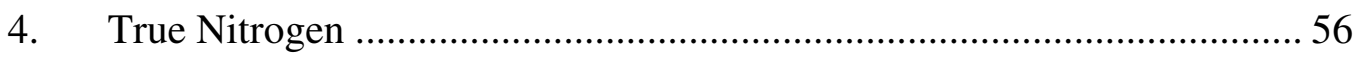

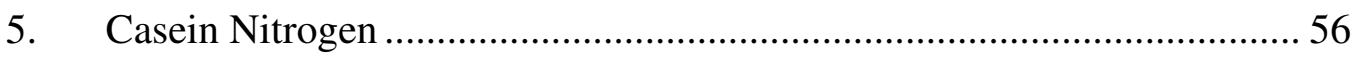

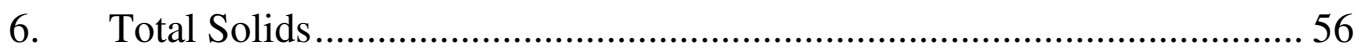

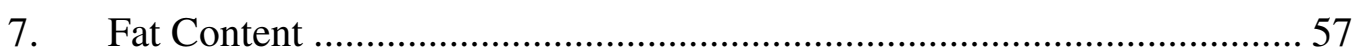

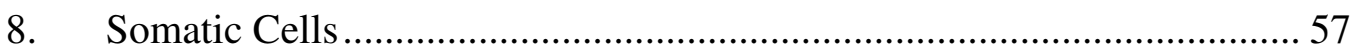

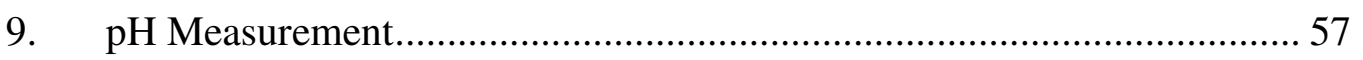

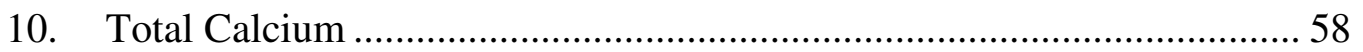

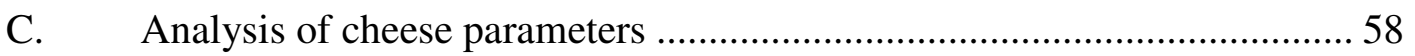

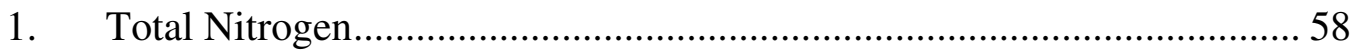

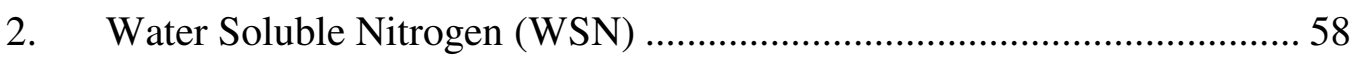

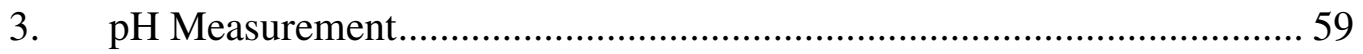

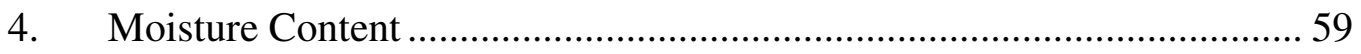

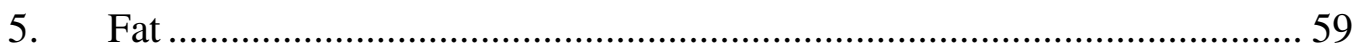

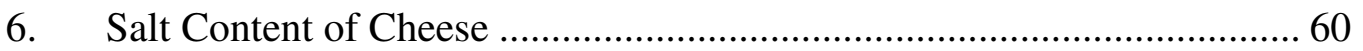

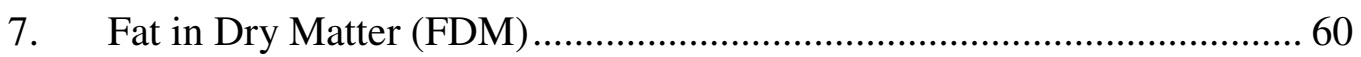

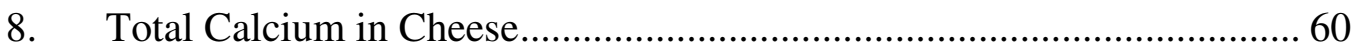

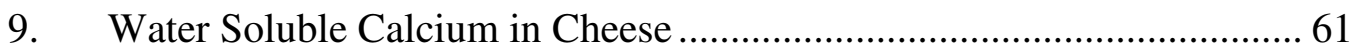

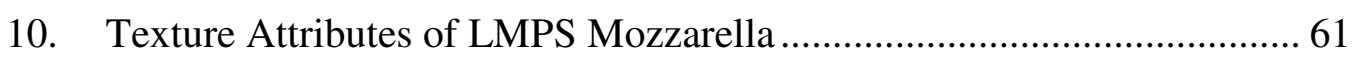

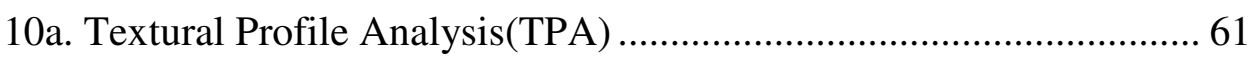

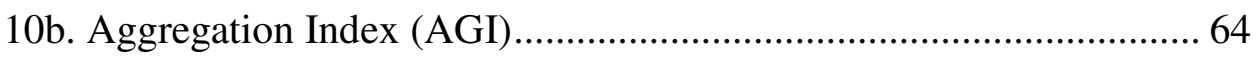

D. Statistical Analysis for Modeling the Seasonal Variation............................ 65

1. Interpretation of R-squared value in Multiple Linear Regression

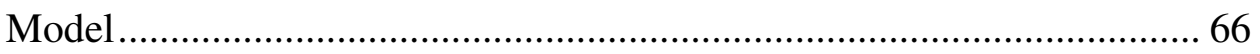

2. Interpretation of the p-value in Multiple Linear Regression

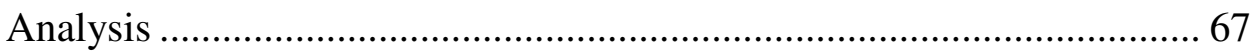

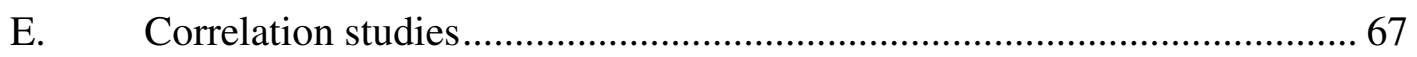

1. Interpretation of the Correlation or Pearson Correlation Coefficient ........ 68

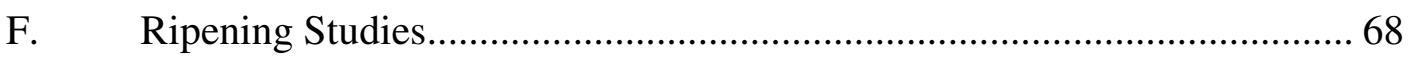

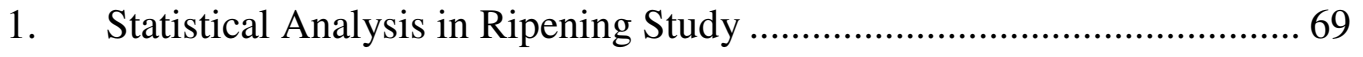

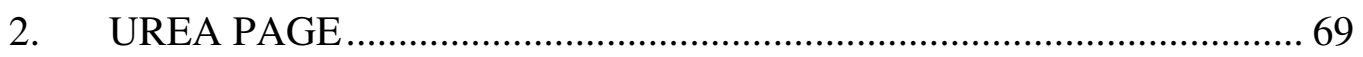

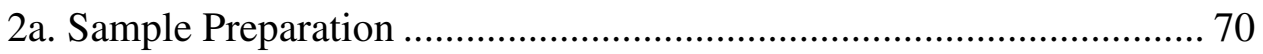

2b Gel Preparation ………................................................................. 70

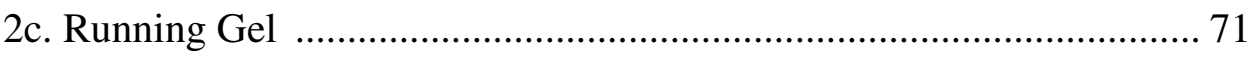




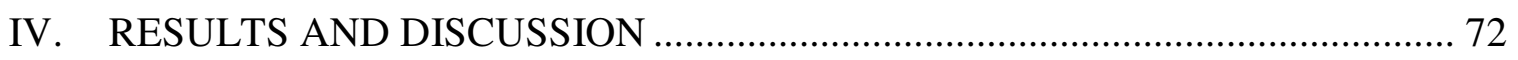

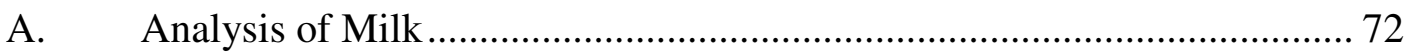

1. Milk Composition............................................................................. 72

2. Correlation of Milk Composition ……................................................. 76

3. Variation of Milk Composition ........................................................ 77

4. Modeling of Milk Components for Seasonal Variation .......................... 83

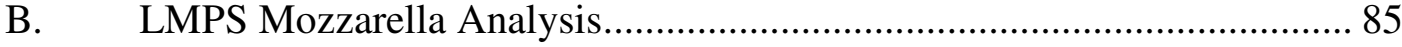

1. Analysis of LMPS Mozzarella Composition.......................................... 86

2. Textural Analysis of LMPS Mozzarella ................................................ 91

3. Effect of Milk Composition on Cheese Composition and Cheese

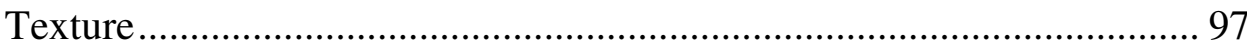

C. The Effect of Temperature on Ripening ............................................ 101

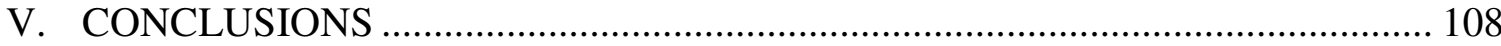

VI. RECOMMENDATIONS FOR FUTURE WORK........................................ 111

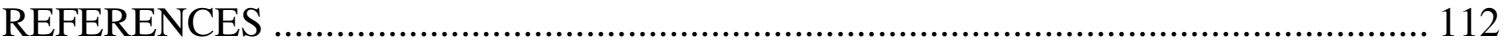

\section{APPENDICES}

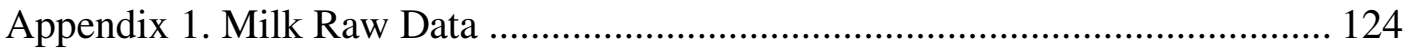

Appendix 2 . Milk Statistics (analyzed in Minitab 17.0) .................................. 133

1. Descriptive Statistics of Milk Composition ................................. 133

2. Regression Analysis of Milk for Total Nitrogen........................ 133

Appendix 3.Temperature Profile in Visalia and Fresno (Central Valley

California) from 2008 -2009 (Obtained from

www.weathersource.com)

Appendix 4.The precipitation in Visalia and Fresno (Central Valley

California) from 2008 -2009 (Obtained from www.weathersource.com)

Appendix 5. LMPS Mozzarella Composition after 5 Days of Manufacture (raw data).

Appendix 6. LMPS Mozzarella Textural Analysis after 5 Days of

Manufacture (raw data) 160

Appendix 7. LMPS Mozzarella Textural Analysis after 5 Days of

Manufacture 162

Appendix 8. LMPS Mozzarella Ripened at $3.3^{0} \mathrm{C}$ for 21 Days (raw data) ......... 163

Appendix 9. LMPS Mozzarella Ripened at $8.9^{\circ} \mathrm{C}$ for 21 Days (raw data) .......... 165 
Appendix 10. Statistical Analysis of 21 days Ripened LMPS

Mozzarella.

1. Descriptive Statistics of Cheese Parameters when

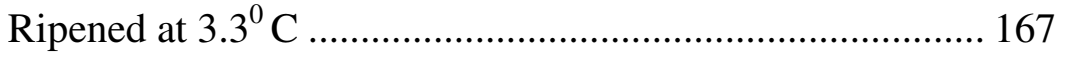

2. Descriptive Statistics of Cheese Parameters when Ripened at $8.9^{\circ} \mathrm{C}$

3. Paired t-tests between Cheese Parameters when Ripened at $3.3^{\circ} \mathrm{C}(38 \mathrm{~F})$ and $8.9^{\circ} \mathrm{C}(48 \mathrm{~F})$ 168 


\section{LIST OF TABLES}

Table 1. Change in types of somatic cells present in milks with increasing somatic cell counts (Taken from Barbano et al. 1987a) 7

Table 2. Casein fractions and importance to cheese making (Taken from Goff,

H.D., 2009)

Table 3. Composition $(\mathrm{g} / 100 \mathrm{~g})$ of cow's milk from various breed (Taken from Huppertz and Kelly, 2009)

Table 4. Seasonal variation of casein to total protein ratio (Taken from Lacroix et al., 1996) 26

Table 5. Composition of milk received by four California cheese plants (Taken from Bruhn \& Franke, 1991). 28

Table 6. Compositional standards for mozzarella in United States (Adapted from Code of Federal Regulation (CFR) 133.155 to 133.158)

Table 7. Factors influencing the shreddability of cheese (Adapted from Childs et al. 2007) 45

Table 8. Specific settings selected for TPA with the TA-XT2 texture analyzer. 62

Table 9. Descriptive statistics for milk composition: 73

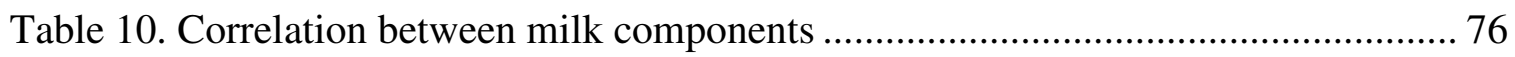

Table 11. Regression analysis results of milk components 83

Table 12. Descriptive statistics for LMPS mozzarella after five days of manufacture 86

Table 13. Correlation between LMPS mozzarella compositions. 91

Table 14. Descriptive statistics for textural properties of mozzarella after five days of manufacture 92

Table 15. Correlation between cheese composition and cheese texture 92

Table 16. Correlation between cheese textural parameters 97

Table 17. Correlation between cheese composition and milk composition. 98

Table 18. Correlation between milk composition and cheese texture 100

Table 19. Statistical analysis of fresh and ripened cheese 103 


\section{LIST OF FIGURES}

Figure 1. Approximate composition of milk (Adapted from Walstra et al., 2006a).......... 5

Figure 2. Coagulum formation in cheese making (Adapted from Wedholm, 2008 and Walstra et al., 2006b)

Figure 3. Changes in the concentrations of fat, protein and lactose over a lactation of a cow (Taken from www.irli.org). 16

Figure 4. Monthly average non- protein nitrogen (NPN) as a percent of total nitrogen (TN) (Taken from Verdi et al. 1987).

Figure 5. Monthly average casein expressed as a percent of total nitrogen (Taken from Verdi et al. 1987)

Figure 6. Monthly average casein expressed for the high and low somatic cell count milk (Taken from Verdi et al. 1987)

Figure 7. Weekly variation in the concentration of protein, fat, lactose (Taken from

Heck et al., 2009)

Figure 8. Variations of total protein in milk (average of seven Quebec cheese plants) (Taken from Lacroix et al. 1996)

Figure 9. Variations of non-casein fraction in milk (average of seven Quebec cheese plants (Taken from Lacroix et al. 1996).

Figure 10. Variations of non-protein fraction in milk (average of seven Quebec cheese plants) (Taken from Lacroix et al. 1996)

Figure 11. Variation of casein to total protein $(\mathrm{CP})$ ratio (Taken from Lacroix et al. 1996) 25

Figure 12. Variation of casein to true protein (CPt) ratio (Takenfrom Lacroix et al. 1996)

Figure 13. Monthly variation of fat from four breeds in California (1974 -1975)

(Adapted from Bruhn \& Franke, 1977).

Figure 14. Monthly variation of protein from four breeds in California (1974 -1975) (Adapted from Bruhn \& Franke, 1977)..... 30

Figure 15. Large scale manufacture of LMPS Mozzarella cheese in enclosed vats

(Taken from McMahon \& Oberg, 2011) 33 
Figure 16. Curd formation after rennetting of milk inside an enclosed vat (Adapted from McMahon \& Oberg, 2011)

Figure 17. Curd mass cut into pieces as it exits the draining, matting and cheddaring belt (Taken from McMahon \& Oberg, 2011) 35

Figure 18. Curd being mechanically stretched in hot water (Taken from McMahon \& Oberg, 2011) 36

Figure 19. Hot mass exiting the cooker/stretcher (Taken from McMahon \& Oberg, 2011)

Figure 20. Mechanical molding of hot cheese into rectangular blocks (Taken from

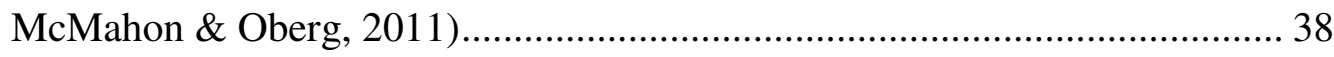

Figure 21. Blocks of LMPS mozzarella entering the brining tank (Taken from McMahon \& Oberg, 2011) 38

Figure 22. Scanning electron micrograph of curd after whey is drained (Taken from McMahon \& Oberg, 2011)...... 39

Figure 23. Scanning electron micrograph of hot LMPS mozzarella after stretching (Taken from McMahon \& Oberg, 2011) 40

Figure 24. Scanning electron micrograph of cheese after four weeks of storage (Taken from McMahon and Oberg, 2011). 49

Figure 25. Level of pH4.6 soluble nitrogen expressed as a percentage of total nitrogen in low moisture mozzarella (Adapted from Feeney et al., 2001). ..... 51

Figure 26. Milk sampling plan 53

Figure 27. The texture profile analysis curve for cheese using TAX-T2 texture analyzer (Adapted from TTC Texture Technologies, 2009). 62

Figure 28. Variation of total solids with respect to total nitrogen, fat, total calcium and casein nitrogen. 77

Figure 29. Variation of Nitrogen fractions (total nitrogen (TN), non-protein nitrogen (NPN), and non-casein nitrogen $(\mathrm{NCN}))$ in milk 78

Figure 30. Variation of casein, casein/total protein ratio, and casein/true protein ratio 78

Figure 31. Variation of fat, total solids, and total calcium in milk 79

Figure 32. Variation of $\mathrm{pH}$ and somatic cell count 79 
Figure 33. Variation of cheese total nitrogen (TN\%), water soluble nitrogen

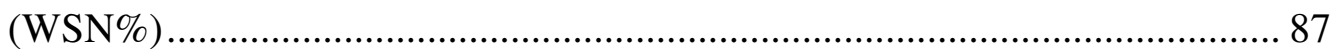

Figure 34. Variation of cheese fat in dry matter (FDM \%), moisture (\%) and salt

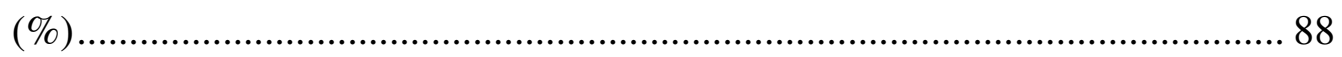

Figure 35. Variation of cheese total calcium (\%), water soluble calcium (WSC \%),

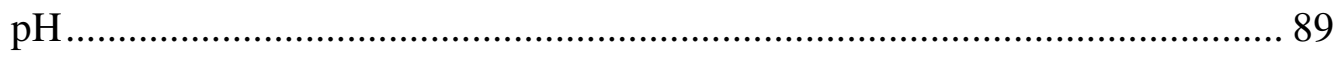

Figure 36. Variation cheese TPA (hardness (H (g)), cohesiveness $(\mathrm{C})$, springiness

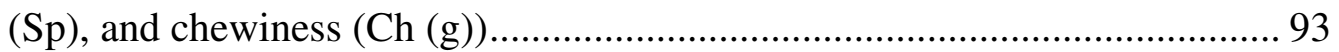

Figure 37. Variation of aggregation index (AGI) and \% loss in shredder. 95

Figure 38. Urea- PAGE of sodium caseinate and LMPS mozzarella ripened at different temperatures. Lane $1 \& 2$ - Sodium caseinate standard. Lane 3, 4, and 5 - Fresh cheese. Lane 6 and 7 - Cheese Ripened at $3.3^{0}$ C. Lane 8 and $9-$ Cheese ripened at $8.9^{\circ} \mathrm{C}$ 106 


\section{INTRODUCTION}

Milk is natures' most nutritious food, and its composition determines the ability to make good quality dairy products. With milk prices being based on the composition (milk fat, true protein, and other dairy solids) dairy farmers have changed their farming practices to produce milk with high protein, fat, and solids (Henrichs et al., 2005). Milk components especially casein, fat, calcium, and $\mathrm{pH}$ influences the cheese making aspects, composition, and yield (Fox \& Cogan, 2004). Therefore, the composition of milk is of great importance for the dairy industry due to the interest in changing the composition of milk to suit the processors and consumers requirements. Seasonal variation of milk composition is due to a combination of factors like heat stress, breed differences, stage of lactation, feeding practices and photoperiod (Laben, 1963). These changes are more pronounced in countries like New Zealand, Ireland, and parts of Australia countries where milk is produced from spring calving herds fed on pasture (Heck et al. 2009). In California, the seasonal variation in milk composition is thought to be minimal because of the large herd sizes, even calving pattern all year round, and feeding mostly concentrates versus pasture (Bruhn \& Franke, 1977). However, in California, some researchers have reported seasonal variation of milk components. Nickerson (1960) found that 18 of 23 milk components varied with season except proteose-peptone, nonprotein nitrogen, two minor phosphorus compounds, and soluble calcium. He also reported that variations in most of the constituents were lowest in May through July and highest in November through January (Laben, 1963). Bruhn \& Franke (1991) found that protein, fat, and solid not fat in milk were higher in winter and lower in summer months in California. Bruhn \& Franke (1977) studied the variation of gross composition of California milk due to breed differences and environmental conditions. They observed 
that the fat and protein concentrations for all breeds were significantly lower from May through August and higher from November through February. To the contrary, Frank et al. (1987) found that there was no variation of protein or its fractions in milk with season in the four regions in California (North Bay, L.A. Basin, S. San Joaquin Valley, and North West Coast) from where milk samples were collected.

Low moisture part skim (LMPS) Mozzarella is a variety of pasta-filata cheese used widely in pizzas in the United States. The extensive use of LMPS Mozzarella in pizzas and other related foods is due to their longer shelf life and good shredding properties. These essential quality attributes are due to their low moisture content $(\leq 52 \%)$ and fat in dry matter $(<45 \%)$ when compared with other types of Mozzarella (Kindstedt et al., 1999). In 1985, about $75 \%$ of all Mozzarella produced was used as an ingredient in food service mainly in pizza (Kindstedt, 1999). The production of low moisture Mozzarella has increased worldwide due to the increase in demand for pizza and related foods. Large-scale production of cheese requires a precise control and monitor of all aspects of cheese making process (Kindstedt et al., 1999). Along with the good manufacturing practices, raw milk quality plays an important role in the Mozzarella yield and quality (Barbano, 1987a). Even though, in California, seasonal variations in milk composition are said to be less, the impact of the variation of milk composition remains in question pertaining to utilization in cheese.

Therefore, in this study, the composition of silo milk (total nitrogen, casein nitrogen, noncasein nitrogen, non-protein nitrogen, true nitrogen, casein, casein to total nitrogen ratio, casein to true nitrogen ratio, fat, total calcium, total solids, somatic cells, and $\mathrm{pH}$ ) collected weekly from a plant in Central Valley, California from July 2008 to December 
2009 was analyzed for any seasonal variation using linear regression analysis. Also, the LMPS Mozzarella manufactured in the same plant during the same period was analyzed on a biweekly basis to see if the seasonal variation of milk composition had any effect on the cheese composition (total nitrogen, water soluble nitrogen, total calcium, water soluble calcium, salt, $\mathrm{pH}$, fat in dry matter and total solids) and un-heated textural characteristics (hardness, cohesiveness, springiness, chewiness, aggregation index and percentage loss in shredder). Correlation analysis was done between milk components and cheese composition and texture for the sampling period (July 2009 - April 2010). To observe if there was any association within milk components, mozzarella components and texture characteristics correlation analysis was done as follows: 1) Between different milk components for the entire sampling period (July 2008 to December 2009) 2) Between different cheese components for the sampling period (July 2008 to November 2009) 3) Between cheese textural characteristics for the sampling period (July 2008 to November 2009) 4) Between cheese composition and textural properties for the sampling period (July 2008 to November 2009). Finally, a ripening study was done to analyze the impact of storage temperature $\left(3.3^{0} \mathrm{C}\right.$ and $\left.8.9^{0} \mathrm{C}\right)$ on $\mathrm{pH}$, water-soluble nitrogen, and the above mentioned textural characteristics of LMPS Mozzarella. 


\section{REVIEW OF LITERATURE}

\section{A. Brief Outline}

This review consists of different parts in relation to the objective of the study. In the first part, how different components of milk affect the cheese composition and quality are discussed briefly. In the next part, factors that affect the milk quality, especially the effect of seasonal variation on milk are reviewed in depth. Then, the manufacture of Low Moisture Part Skim (LMPS) Mozzarella and characteristics of the cheese structure in relation to its composition are discussed. Next, the functional properties of LMPS Mozzarella before heating such as shreddability, matting behavior, and textural properties are briefly summarized. Finally, the chemical and functional changes that Mozzarella undergoes during proteolysis are examined.

\section{B. Milk Composition}

Milk is a complex fluid matrix consisting of nutritious components that makes it a "Complete Food". The composition of milk with approximate concentrations is shown in Figure 1 (Walstra et al., 2006a). 


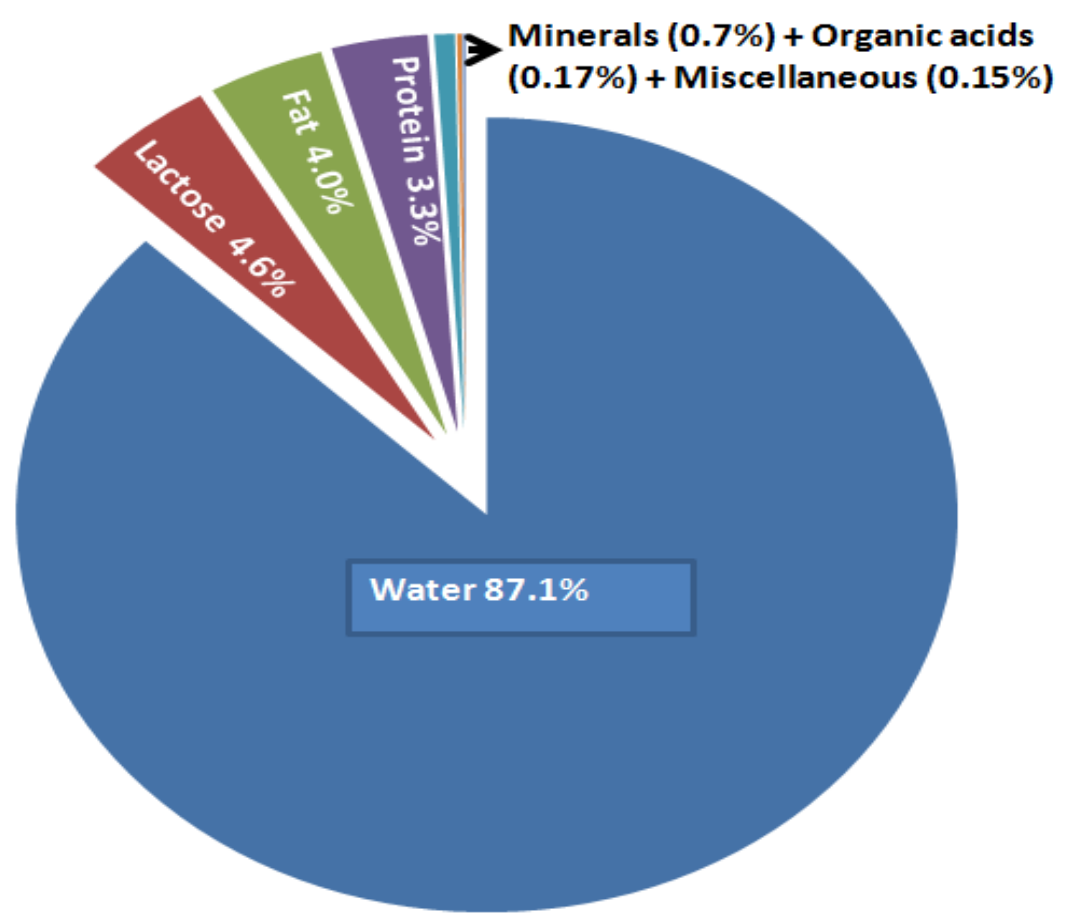

Figure 1. Approximate composition of milk (Adapted from Walstra et al., 2006a)

\section{Quality of Milk affecting Cheese Quality}

In Italy, Mozzarella was traditionally made from buffalo milk due to its characteristic aroma and physical attributes. Due to the decreasing water buffalo herd numbers, a transition from buffalo milk to cow milk was made in the 1950s (Rankin et al, 2006). In the US, LMPS Mozzarella cheeses are made from cow's milk. Milk components, especially casein, fat, calcium, and $\mathrm{pH}$, influence the cheese making aspects, composition, and yield (Fox \& Cogan, 2004). Therefore, the effect of each constituent on cheese is discussed briefly below.

\section{Somatic Cell Count (SCC)}

To make good quality cheese, the raw milk should have low bacterial and somatic cell counts. During udder infections and damage, somatic cells are released from the blood. 
However, milk from healthy cows also contains low numbers of somatic cells in the form of epithelial cells $(<100,000$ cells/ml). Apart from infections, late stage of lactation, heat stress, and poor feeding practices contribute to high levels of SCC (Rankin et al., 2006). An increased SCC in raw milk affects the constituents of milk and thereby affects rennet coagulation properties, syneresis, and cheese yield (Verdi et al., 1987).

Epithelial cells or other somatic cells in milk from non-mastitis or normal cows constitute $80 \%$ of the SCC (SCC < 100,000 cells/ml) (Barbano et al., 1987a). In milk from cows with subclinical mastitis ( $\mathrm{SCC} \geq 500,000$ cells/ml) or mastitis ( $\mathrm{SCC}>1,000,000$ cells/ml), neutrophils are present more than 26 fold and lymphocytes are present more than 3.9 fold when compared to normal milk (SCC $<100,000$ cells/ml) (see Table 1). Neutrophils are a type of white blood cells that carry very active proteases, lipases, phospholipases, and specific chemicals to fight infection and tissue damage. During cheese making, levels of protease and lipase enzymes makes the curd weak due to break down of casein, fat, etc., and hence causes a lot of shattering during cutting and milling. This causes more fines, impaired whey drainage, and higher moisture content in the cheese (Barbano et al., 1987a). 
Table 1. Change in types of somatic cells present in milks with increasing somatic cell counts (Taken from Barbano et al. 1987a)

\begin{tabular}{llccc}
\hline Milk type & \multicolumn{3}{c}{ Somatic Cell type } & \\
\cline { 2 - 5 }$($ cells per $\mathrm{ml})$ & & Lymphocytes & Neutrophils & Epithelial \\
\hline Normal & \% of Total & 6.1 & 9.1 & 84.8 \\
$(<100,000)$ & Number & 6061 & 9091 & 84,848 \\
& & & & \\
Subclinical & \% of Total & 4.8 & 47.6 & 47.6 \\
Mastitis & Number & 23,809 & 238,095 & 238,095 \\
$(\geq 500,000)$ & Increase & $3.9 \mathrm{X}$ & $26 \mathrm{X}$ & $2.8 \mathrm{X}$ \\
& & & & \\
Clinical & \% of Total & 2.6 & 71.6 & 25.8 \\
Mastitis & Number & 25,848 & 716,000 & 258182 \\
$(\geq 1,000,000)$ & Increase & $4.3 \mathrm{X}$ & $79 \mathrm{X}$ & $3.0 \mathrm{X}$ \\
\hline
\end{tabular}

In full-blown mastitis, there is usually leakage of blood plasma into the milk because of the damaged cells in the udder. The blood plasma contains the proteolytic enzyme "Plasmin" that breaks down the casein during processing and storage (Barbano et al., 1987a). Plasmin can survive ultra-high temperatures and also plasmin gets activated from the inactive form "Plasminogen" at pasteurizing temperatures which makes it challenging to control during processing (Barbano et al., 1987a).

In California, the legal limit for SCC in commercial milk is less than or equal to 750,000 cells/mL (Rankin et al., 2006). Apart from affecting the casein and fat content, increased somatic cell count also decreases the starter activity, which affects the quality of cheese (Rankin et al., 2006; Barbano et al., 1987a; Verdi et al., 1987). Mixing of high somatic cell count milk with low count milk also causes breakdown of milk casein and fat but storing at lower temperatures would slow down the damage (Barbano et al., 1987a). 


\section{Protein}

Total protein consists of three main fractions - casein, whey protein and non-protein, and these constitute $77.9 \%, 17.2 \%$ and $4.9 \%$ respectively, (Walstra et al., 1999). In cheese making, during coagulum formation, casein forms the main structural framework by trapping fat and moisture. This network formation and its properties determine to a larger extent the amount of other milk constituents retained in cheese (Walstra et al., 2006b). Bovine casein is present in milk as aggregates and contains the colloidal calcium phospahte (CCP). Casein precipitates out at $\mathrm{pH} 4.6$, and as the $\mathrm{pH}$ is lowered, the $\mathrm{CCP}$ dissolves into soluble phase (Walstra et al., 2006c). Casein micelle consists of four individual components known as $\alpha_{\mathrm{s} 1^{-}}$casein, $\alpha_{\mathrm{s} 2}$ - casein, $\beta$ - casein and $\kappa$ - casein in the approximate ratios of 4:1:4:1 (w/w) (Banks, 2007). A portion of the $\beta$-casein is divided into gamma casein and proteose peptone by the action of proteolytic enzymes. Each of the four main casein components varies due to the degree of phosphorylation, glycosylation, disulphide bonding, proteolysis and genetic polymorphism (Walstra et al., 2006c). Banks (2007) reported that the BB genotypes of $\beta$ - lactoglobulin and $\kappa$ - casein have a good effect on the rennetting properties, cause higher recoveries of fat, less loss of fines in whey, and high yields. The casein fractions and some properties important to cheese making are shown in Table 2. 
Table 2. Casein fractions and importance to cheese making (Taken from Goff, H.D., 2009)

\begin{tabular}{lcl}
\hline Name & Casein (\%) & Properties \\
\hline$\alpha_{\mathrm{s} 1}$-casein & 38 & $\begin{array}{l}\text { Binds calcium strongly } \\
\text { Sensitive to break down by rennet } \\
\text { Resists the milk protease, plasmin }\end{array}$ \\
$\alpha_{\mathrm{s} 2}-$ casein & 10 & $\begin{array}{l}\text { Most calcium sensitive } \\
\text { Binds calcium strongly }\end{array}$ \\
$\beta$ - casein & 34 & $\begin{array}{l}\text { Partially soluble in cold milk } \\
\text { Breakdown by plasmin not by rennet }\end{array}$ \\
$\kappa$ - casein & 15 & $\begin{array}{l}\text { Stabilizes casein particles against coagulation } \\
\text { Bonds with whey proteins during heating }\end{array}$ \\
\hline
\end{tabular}

The cheese milk is standardized to constant casein to fat ratio to get good cheese quality and yield. Though casein plays an important role in cheese making, Lacroix et al. 1996 mentioned, "There is not a simple, accurate and automated procedure that could be applied for the casein determination in milk in industry." In dairy plants, caseins are often estimated by assuming constant casein to total protein ratio of 0.78 (Walstra et al., 2006b). Lacroix et al. (1996) observed monthly variation of casein to total protein ratio $(\mathrm{CP})$ and casein to true protein ratio $\left(\mathrm{CP}_{\mathrm{t}}\right)$ in Quebec in commingled milk from seven plants for 14 months. The average monthly difference of $\mathrm{CP}$ and $\mathrm{CP}_{t}$ was $2.29 \%$ and 1.94\% respectively for the 14 months. In California, Nickerson (1960) and Bruhn \& Frank (1977) reported variation of protein over the season (high in summer months and low in winter months), and hence there might be variation of casein over the different seasons as well. This variation calls for a close monitor of casein to protein ratios when standardizing milk. However, Frank (1987) reported no variation of protein over the seasons in California. 


\section{Fat}

Fat is present in milk as small globules, and its size is known to vary according to the cow breed. During the maturation process, fat via lipolysis imparts texture, flavor, and aroma to cheese. In the coagulum, fat is trapped by the casein network, and its presence in the curd inhibits syneresis thereby influencing the moisture retention of the curd (Banks, 2007). Low fat cheese is hard in texture and lacks flavor. Even one percent fat can produce considerable flavor in cheese and this is widely exploited in the low fat cheese industry (Neil, 2010).

\section{4. $p H$}

The $\mathrm{pH}$ of milk plays an important role in cheese making, and the milk composition, especially the amount of salts, influence the $\mathrm{pH}$ value. The $\mathrm{pH}$ of natural milk is about 6.7 but varies slightly (Kelly, 2007a). The use of refrigeration in milk handling and storage has minimized the acid producing bacteria thereby maintaining the $\mathrm{pH}$ close to 6.7. The $\mathrm{pH}$ increases slightly in late lactation milk, mastitis milk, and during storage due to loss of $\mathrm{CO}_{2}$. This increase in $\mathrm{pH}$ is not suitable for the action of chymosin, which requires an acidic pH optimum function (Kelly, 2007a). Pre-acidification of milk is done at the start of the cheese making process to offset the increase in $\mathrm{pH}$. The milk is preacidified by adding acid (acidogen, gluconic acid lactone, etc.) or by limited growth of lactic acid starter followed by pasteurization (Fox \& Cogan, 2004). 


\section{Salts}

Salts are present in low quantities in milk as metallic components (sodium, potassium, calcium, magnesium, manganese, iron, and copper) and non-metallic elements such as sulphur, chlorine, and phosphorous (Neil, 2010).

Calcium is the most important salt in cheese making, and it is partitioned between the colloidal phase (calcium phosphate within the casein micelles) and the soluble phase of milk. After rennet coagulation, the formation of the rennet coagulum is dependent on the amount of soluble calcium and insoluble calcium present in the milk. Calcium ions neutralize the negative charges on the casein micelles by forming bonds between negatively charged phosphate groups on the casein micelles. The coagulation time and firmness depend on the calcium ion activity (Kelly, 2007b).

The partition of calcium into soluble and insoluble form depends on the $\mathrm{pH}$. As the $\mathrm{pH}$ decreases, the colloidal calcium becomes more soluble and is completely solubilized at $\mathrm{pH}$ 4.6. The amount of calcium retained in curd will depend on the $\mathrm{pH}$ at which the whey is drained. Calcium chloride is often added to cheese milk to fasten the rate of coagulation and increase the firmness of the curd (Fox and Cogan, 2004).

\section{Miscellaneous Components}

Lactose acts as the substrate for the starter cultures to produce lactic acid, and hence, aids in acid production during cheese making. Approximately $10 \%$ of the lactose is used by the starter bacteria to produce lactic acid, and the remaining is lost with the whey (Neil, 2010). For cheeses used in pizza, the galactose component of the lactose molecule gives the desired browning. Galactose is obtained by adding appropriate cultures that utilizes 
only the glucose molecule of the disaccharide lactose for acid production (McMahon \& Oberg, 2011).

Different enzymes gain entry into milk through bacteria present in the teats canals or from organisms present in the environment. These enzymes affect the quality of raw milk and can affect the fats and proteins during ripening to impart delicate flavors and aromas in aged cheese (Neil, 2010). Milk fat contains the fat-soluble vitamins (A, D, E and K), and most of the water-soluble vitamins (B complex and vitamin $\mathrm{C}$ ) are lost during the draining of whey. These vitamins act as food for the bacteria to grow during cheese ripening (Neil, 2010).

\section{Milk Components and Cheese Making}
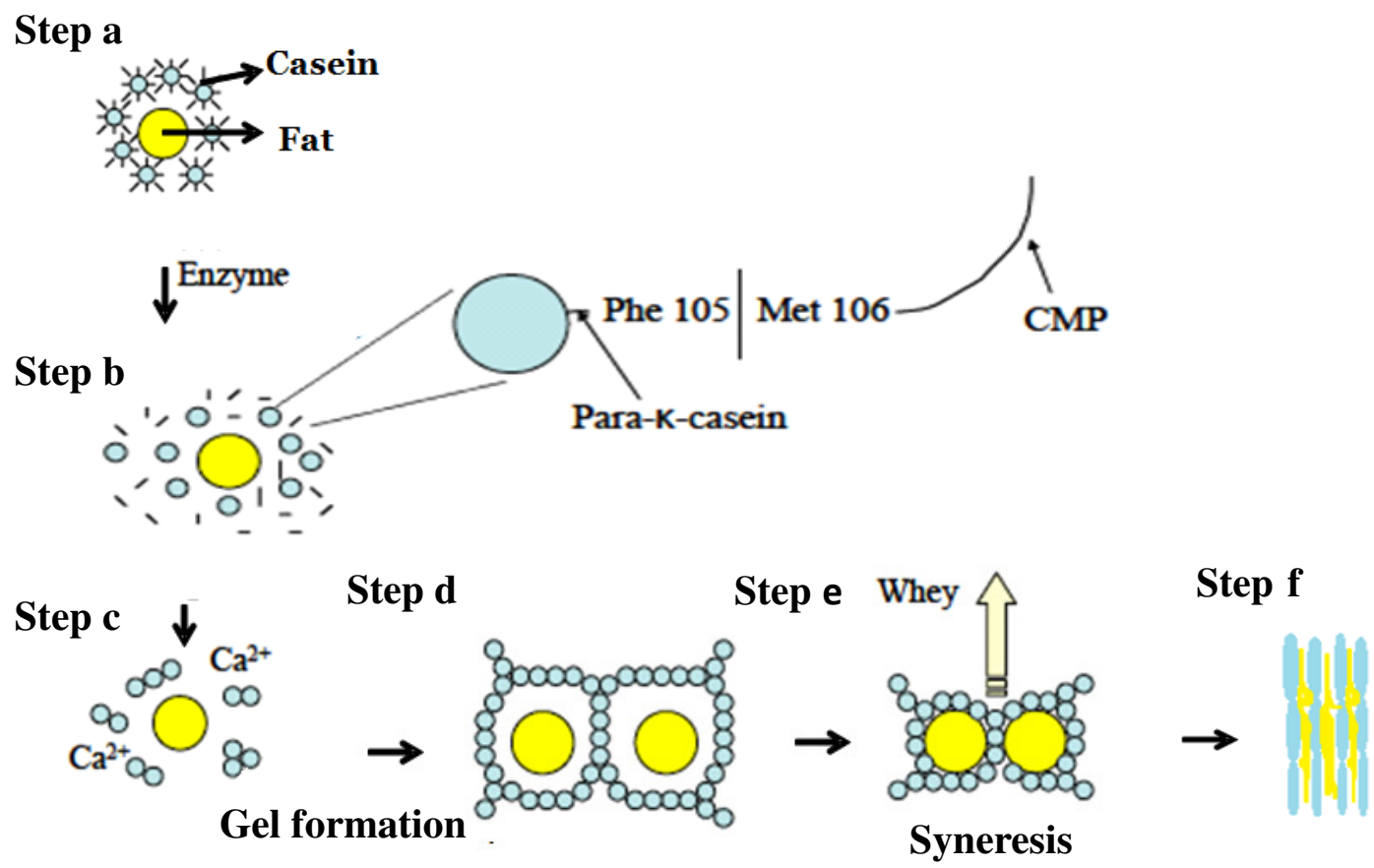

Figure 2. Coagulum formation in cheese making (Adapted from Wedholm, 2008 and Walstra et al., 2006b)

The chemistry behind cheese making is summarized below. $\kappa$-casein, which has a negative charge, is present on the surface of the casein micelles that make the casein 
micelles repel each other in the milk serum. The casein molecules also trap the milk fat globules (Figure 2, step a). The clotting steps occur in two steps. First, when rennet is added, it cleaves the $\mathrm{Phe}_{105}-\mathrm{Met}_{106}$ bond of $\kappa$-casein into para- $\kappa$-casein, which stays with the casein micelle and a hydrophilic caseinomacropeptide (CMP) that ends up in the whey fraction (Figure 2, step b). The para- $\kappa$-casein micelles, which have a neutral net charge, form small-elongated shaped aggregates (Figure 2, step c). This is followed by the non-enzymatic second stage in which a three dimensional network is formed by the aggregation of para-א-casein micelles under the influence of calcium ions. A gel/coagulum is formed that traps the fat and moisture. This coagulum gets firmer as more bonds are forms by the hydrophobic and electrostatic interactions between the micelles and also by calcium phosphate linkages between the micelles (Figure 2, step d). The clotting process is influenced by calcium concentration, $\mathrm{pH}$ and temperature. Syneresis (expelling of the whey) occurs when the gel is cut, and it is further enhanced during the cooking, stirring, and cheddaring process (Wedholm, 2008; Fox \& McSweeney, 1998; Walstra et al., 2006b). Due to the pressure applied, some bonds are broken, and new ones are formed, and hence, expelling the whey out in the process. Other factors that influence syneresis are increased temperature and reduced $\mathrm{pH}$ of milk. In the mozzarella process, the milled curd is plasticized, kneaded, and stretched with heat. The curd fibers reorganize and orient themselves in a unidirectional direction giving Mozzarella the characteristic texture (Figure 2, step f) (Kindstedt et al., 1994).

\section{Factors affecting Milk Composition}

As described earlier, milk components play an important role in cheese making. Milk composition varies within a country and from one region to another (Barbano, 1987a). 
This variation is caused by a combination of genetic and environmental factors like age, stage of lactation, feeding, health status, and climatic conditions (Fox \& McSweeney, 1998). The various factors that bring about changes in the milk composition are discussed briefly below.

\section{Genetic}

Selective breeding of dairy cattle is done to increase the milk yield and produce milk with more fat and protein. In the US, $90 \%$ of the dairy herd consists of Holsteins. The Holsteins are known for producing large volumes of milk and have dominated milk production since 1945. Jersey represents 7\% and Ayrshire, Brown Swiss, Guernsey, and Milking Shorthorn makes up 2\% of the milking herd population (Wendroff \& Paulus, 2011). Milk composition varies between breeds, and breed selection has decreased this variability to a great extent (Huppertz \& Kelly, 2009).

Table 3. Composition (g/100g) of cow's milk from various breed (Taken from Huppertz and Kelly, 2009)

\begin{tabular}{lccccc}
\hline Breed & Fat & Protein & Lactose & Ash & Total solids \\
\hline Ayreshire & 4.0 & 3.3 & 4.6 & 0.7 & 12.7 \\
Brown Swiss & 3.8 & 3.2 & 4.8 & 0.7 & 12.7 \\
Guernsey & 4.6 & 3.5 & 4.8 & 0.8 & 13.7 \\
Holstein & 3.6 & 3.0 & 4.6 & 0.7 & 11.9 \\
Jersey & 5.0 & 3.7 & 4.7 & 0.8 & 14.2 \\
\hline
\end{tabular}

Nitrogen composition of milk varies between breeds. Holstein milk has the lowest casein and true protein, and jersey cows have the highest values (Depeters \& Ferguson, 1992). 
Apart from breeding, environment and various physiological factors also influence the yield and composition of milk (Glantz et al., 2009).

\section{Interval between Milkings}

The fat content of milk varies between the morning and evening milk due to a shorter interval between the morning and evening milking than between the evening and morning milking. Milking of cows at regular intervals will reduce this variability. SNF and protein content does not vary much with the milking interval (Walstra et al. 2006a).

\section{Completeness of Milking}

Fat droplets tend to accumulate in the upper portions of the alveoli due to their low specific gravity. Hence, the first milk drawn from the udder is low in fat while the last drawn milk is high in fat. However, there is no net loss of fat as it is picked up in subsequent milkings. Also, mixing of milk tends to even out this variability (Nickerson, 1999).

\section{Age and Stage of Lactation}

As the cow ages, with each successive lactation, the fat and solid not fat content decreases by about $0.02 \%$ and $0.12 \%$, respectively (Laben, 1963). The fat, lactose, and protein contents of milk vary according to stage of lactation as shown in (Figure 3). Solids-not-fat (SNF) content is usually highest during the first two to three weeks, and then a slight decrease is observed. The protein content of milk tends to be higher during the initial and later part of the lactation period and decrease at about 60 days of the lactation cycle. The fat content tends to increase during the later part of the lactation. However, the protein to fat ratio is highest at about 60 days of lactation (peak of 
lactation) and lowest at the end of lactation period (www.irli.org). The proportion of alpha-caseins decreases during lactation while the beta-casein increases, which affects the cheese ripening and flavor (Goff, H.D. 2009).

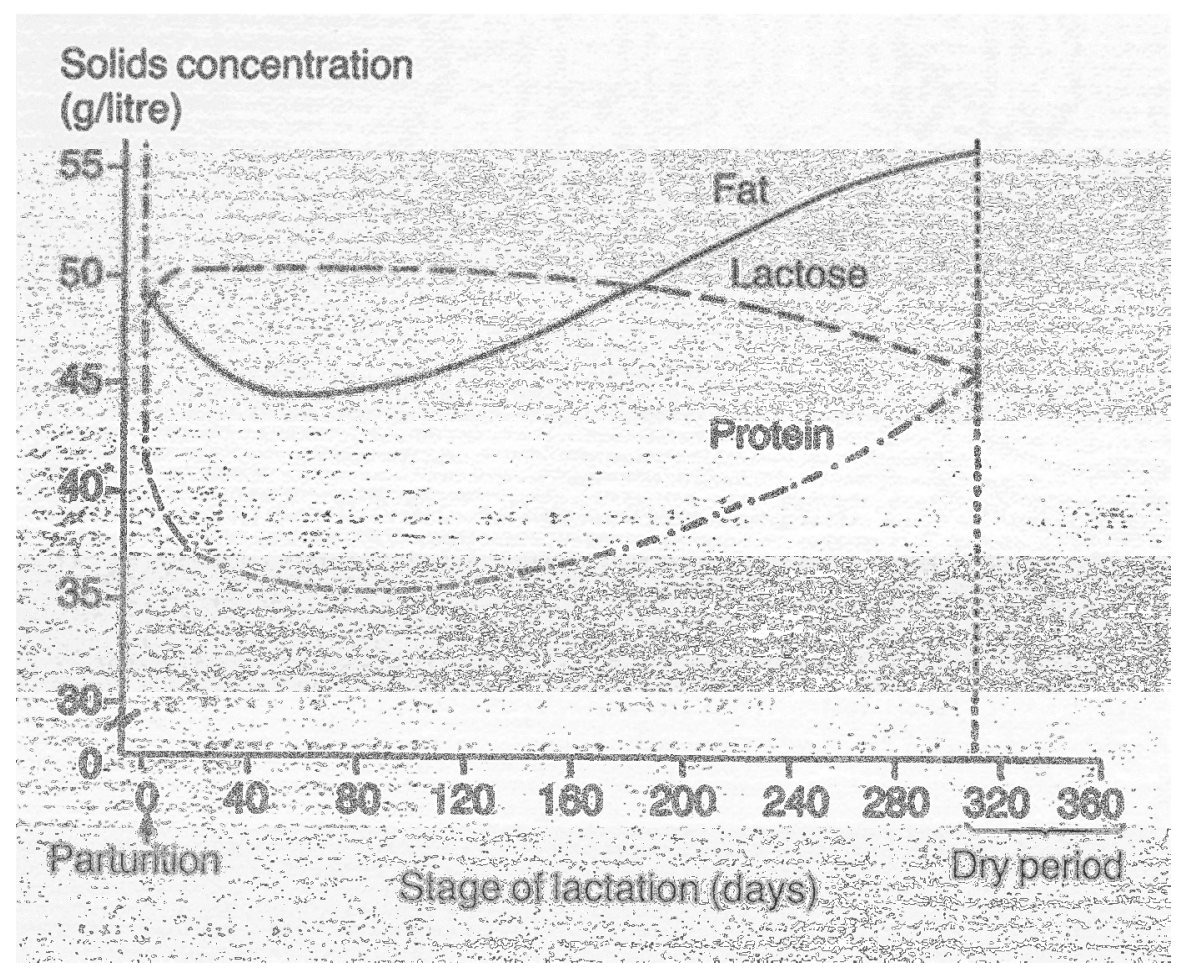

Figure 3. Changes in the concentrations of fat, protein and lactose over a lactation of a cow (Taken from www.irli.org)

\section{Feeding Regime}

Diet of the cows can alter fat and milk protein content of milk. Fat is the most sensitive component to dietary changes and varies by 3.00 percentage units whereas the protein content changes only about 0.60 percentage units. The lactose and mineral content of milk do not vary much with dietary manipulations (Looper, www.uaex.edu). Generally less roughage and high energy feeds will encourage higher fat content with a little increase in protein content to provide a higher protein to fat ratio (Schroeder, 2012). 


\section{Disease}

Disease can raise the normal body temperature of lactating cow, and this can affect the milk yield and composition. Laben (1963) observed that mastitis could reduce the yield of milk, SNF, and protein up to 10 to $12 \%$. Though other diseases tend to affect milk composition, mastitis is the most widely studied disease that affects the milk composition. Even subclinical mastitis is also known to increase the somatic cell count, sodium, chloride, free fatty acids, and levels of blood constituents in milk and decrease fat, solids-not-fat, and lactose. Mastitis does not change the total protein content significantly, but a decrease in the level of casein and an increase in the levels of albumin and immunoglobulin have been reported (Dohoo \& Meek, 1982). These changes in the milk from mastitis cows decrease the cheese yield and alter the quality of cheese produced (Looper, www.uaex.edu).

\section{Seasonal Variation}

Milk generally has higher fat and protein content during the winter and fall months and lowest during the spring and summer months. This variation is attributed mainly to change in climatic conditions and feeding regime. During spring, the green pastures tend to provide low fiber in diet, whichdecreases the fat and protein content in milk. In summer months, the heat stress reduces the dry matter intake resulting in decrease of fat and protein content (Looper, www.uaex.edu). Apart from diet and hot weather, stage of lactation, calving patterns, humidity, photoperiod, somatic cell count, etc., also contribute to variation in milk composition. Hence, it is difficult to single out one factor as the main cause to seasonal variation is due to a combination of multiple factors (Fox \& Cogan, 2004). 


\section{7.a. Studies on Seasonal Variation of Milk Composition}

Bernabucci et al. (2002) studied the variation of milk composition with regard to the environmental temperature for two seasons: spring and summer. The study comprised of 40 mid lactating Holstein cows in central Italy. The feed during the study was a ration based feed with concentrates given by self-feeders. The cows were balanced for genetic index, housed, and milked in the same way for the entire study. During the experiment, the average temperature was $11.6^{\circ} \pm 2.6^{\circ} \mathrm{C}$ in spring during daytime and $6.4^{\circ} \pm 3.5^{\circ} \mathrm{C}$ during nighttime. In summer, the temperature was $29.9^{0} \pm 2.9^{\circ} \mathrm{C}$ during daytime and $21.9^{0} \pm 4.1^{0} \mathrm{C}$ during nighttime. They found that milk yield during the summer was $10 \%$ lower $(p$-value $<0.01)$ than during the spring. Milk protein percentages were $9.9 \%$ lower ( $p$-value $<0.01)$ in the summer than in the spring $(3.01 \%$ vs. $3.31 \%$, respectively). Casein percentage and casein number were lower $(p$-value $<0.01)$ in the summer than in the spring (2.18\% vs. $2.58 \%$ and $72.4 \%$ vs. $77.9 \%$ for casein content and casein number, respectively). $\alpha_{\mathrm{s}}$-casein and $\beta$-casein content were lower $(\mathrm{P}<0.01)$ in the summer milk. There was no difference found for $\kappa$-casein and somatic cells between seasons. They found that summer cows consumed less dry matter, protein, and energy than spring cows due to heat stress, which contributed to less milk yield and protein in the summer milk. Ozrenk \&Inci (2008) studied the seasonal effect on milk composition in Van Province Turkey. They collected milk from 12 points in the region during winter (January March) and summer (June - August). They found that milk fat, protein, and total solid percentages were significantly higher during the winter than the summer months. They suggested that these changes might be due to the feeding pattern (high grains diet and low fiber diets in winter), difference in photo light period and temperature differences. 
Bertocchi et al. (2013) investigated annual, seasonal, and monthly variations in milk characteristics (somatic cell count, total bacterial count, fat, and protein percentage) and thermal humidity index (THI) -milk characteristics relationships over a seven-year period (2003-2009) in Holstein dairy farms in Po Valley, Italy. They found high somatic cell count, total bacterial counts, lower fat, and protein percentage in summer months.

However, they reported that the THI - milk characteristics study suggested that heat load was not the main factor contributing to fat and protein decrease. They speculated that the photo-period and lactation stage might be the contributing factor.

Verdi et al. (1987) observed that the milk protein and fat varied seasonally in their twoyear study from 24 plants in the New York area. They found that the non-protein nitrogen (Figure 4) and casein (Figure 5) were lowest in July and August, and the highest were in October and November.

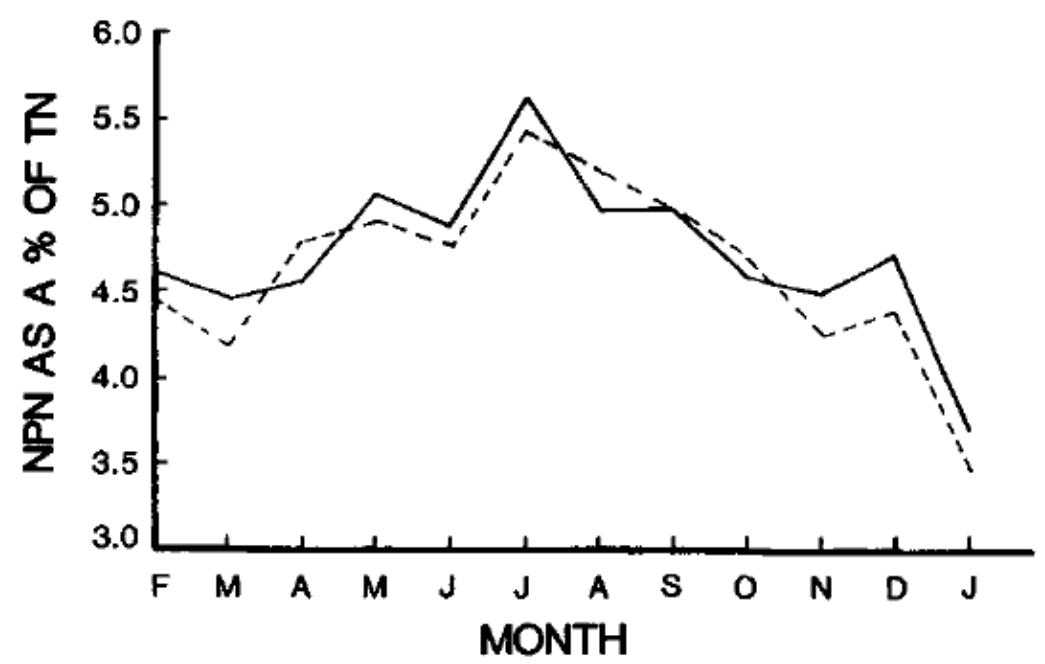

Figure 4. Monthly average non- protein nitrogen (NPN) as a percent of total nitrogen (TN) (Taken from Verdi et al. 1987) 


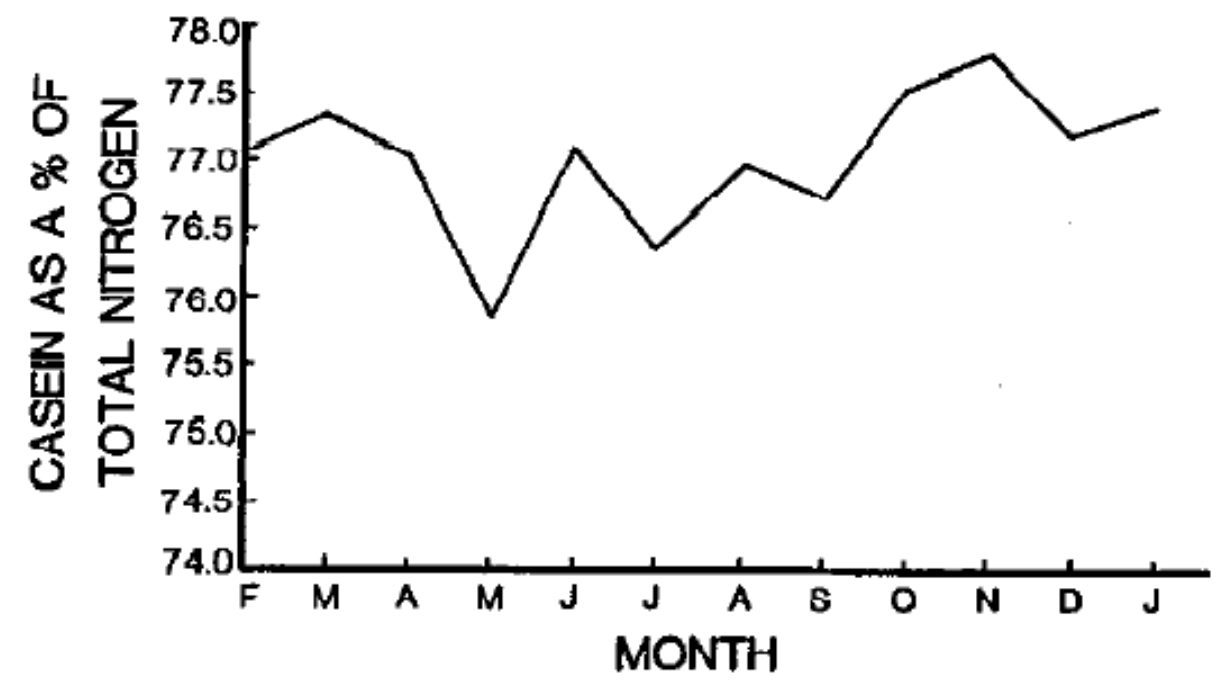

Figure 5. Monthly average casein expressed as a percent of total nitrogen (Taken from Verdi et al. 1987)

Verdi et al. (1987) also observed that the casein was low in high somatic cell (>500,000 cells/ml) than in low somatic milk $(<200,000$ cells/ml) (Figure 6).

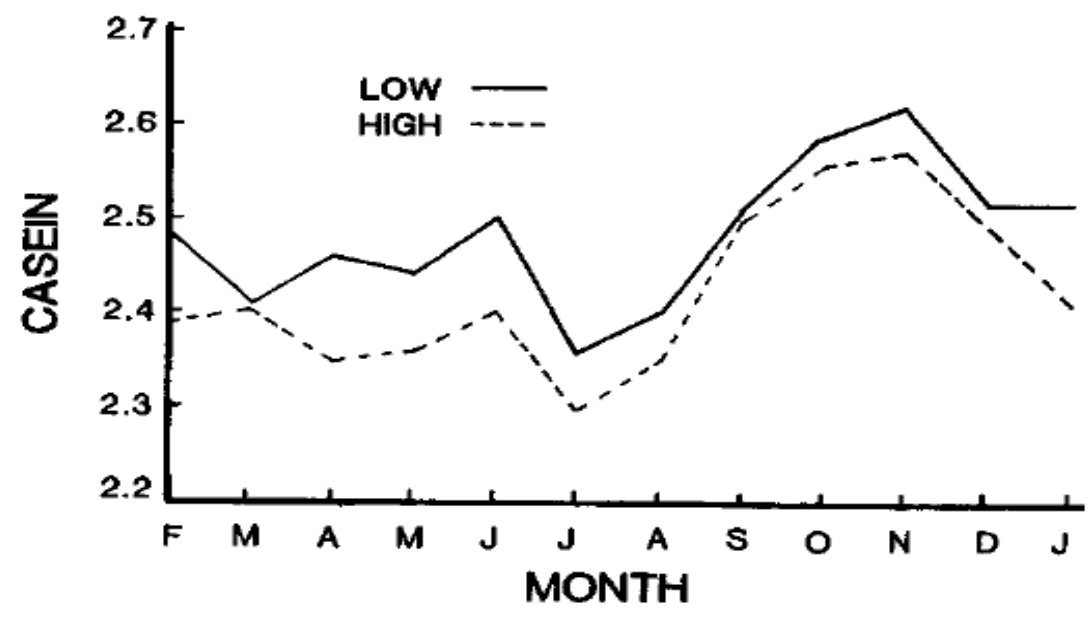

Figure 6. Monthly average casein expressed for the high and low somatic cell count milk (Taken from Verdi et al. 1987)

Heck et al. (2009) collected bulk milk samples from seventeen milk plants in Netherlands from February 2005 to February 2006. In their study, they observed a higher fat in the winter months than summer months in the milk and attributed this change to silage diet in 
winter rather than a pasture diet in summer. They noticed only a minimal change in protein content during the season i.e. more protein during winter and less during summer (Figure 7).

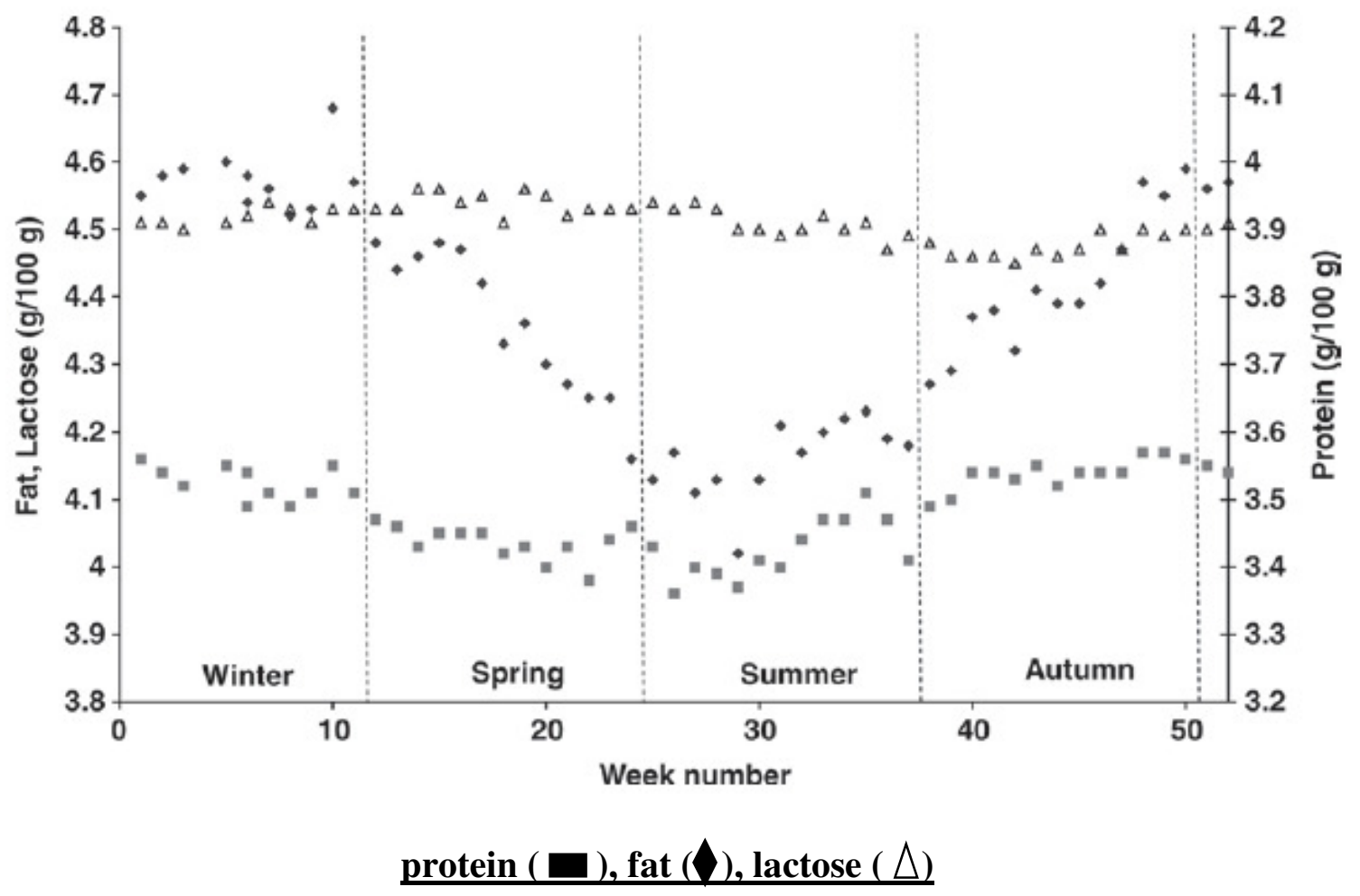

Figure 7. Weekly variation in the concentration of protein, fat, lactose (Taken from Heck et al., 2009)

Larsen et al. (2010) reported a difference in the concentrations of fat and carotenoids in different parts of Sweden and variation in fat during the different seasons. They attributed both these differences due to feed changes.

Paval \& Gavan (2011) reported a lower fat, protein, solids not fat, somatic cell, and freezing point of milk during the spring than autumn in milk samples collected at research station in Romania. They observed that fat, solid not fat, and somatic cells varied more than protein and speculated that this variation might be partially due to feed and temperature difference in different seasons. 
Dohoo \& Meek (1982) in their review reported that the somatic counts were lowest during winter and the highest during the summer with high levels usually reported in July and August, and the somatic cell counts were generally higher from April through October. They said that the somatic cells remained high even after the temperature index started to decline and called this "summer carry over." Dohoo \& Meek speculated that the increase in somatic cell count during summer may be not entirely due to elevated temperatures because higher somatic cell counts were not observed in a study where cows were housed in environmentally controlled chambers with increased temperatures. They attributed the increase in somatic cell counts to diet changes as they mentioned that in Scandinavia cows on pasture diet had higher cell counts than cows confined to barns during summer time.

Lacroix et al. (1996) collected milk samples from seven plants for a 14- month period (September 1991- October 1992) in Quebec to study the seasonal and regional variations in the nitrogen fractions and their effects on the ratios of casein to total protein (CP) and true protein $\left(\mathrm{CP}_{\mathrm{t}}\right)$. They used a second order periodic oscillatory Fourier model to test for statistically significant effects of $\mathrm{CP}$ and $\mathrm{CP}_{\mathrm{t}}$ variation for different seasons. They reported small but highly significant differences in nitrogen fractions of co-mingled milk among different regions and seasons. In addition, lower-total nitrogen (protein) concentrations were observed in May and July with a maximum in September - October (Figure 8). A similar pattern was observed for non-casein nitrogen (NCN) (Figure 9). However, the non-protein nitrogen fraction remained relatively constant from January to April, and then, it increased until September and then decreased (Figure 10). The casein to total protein $(\mathrm{CP})$ and casein to true protein $\left(\mathrm{CP}_{\mathrm{t}}\right)$ varied inversely to that of total 
nitrogen and NCN, with a maximum in April followed by a steep decrease to a minimum in August (Figure 11 and Figure 12). From the model, seasonal variation represented $63.5 \%$ and $55.5 \%$ of the total variation for $\mathrm{CP}$ and $\mathrm{CPt}$ respectively. Due to seasonal variations, they suggested that the second order "Fourier Periodic Oscillatory Model" used in this study was found to be more suitable for determining the variation of casein over different seasons instead of using fixed casein to protein ratio throughout the year. They summarized the $\mathrm{CP}$ ratios variation from other studies and noted that the mean $\mathrm{CP}$ ratios varied between $74.8 \%$ to $82.4 \%$ (Table 4 ). When they fitted the CP data from other studies in the "Fourier Periodic Oscillatory Model" used in this study, a significant seasonal variation of $\mathrm{CP}$ with a $\mathrm{R}^{2}$ value of $82 \%$ was observed in few studies where the sample size was large. In some other studies they did not find any significant seasonal variation of $\mathrm{CP}$ especially where the $\mathrm{CP}$ variations were small and/or the $\mathrm{CP}$ data was largely scattered.

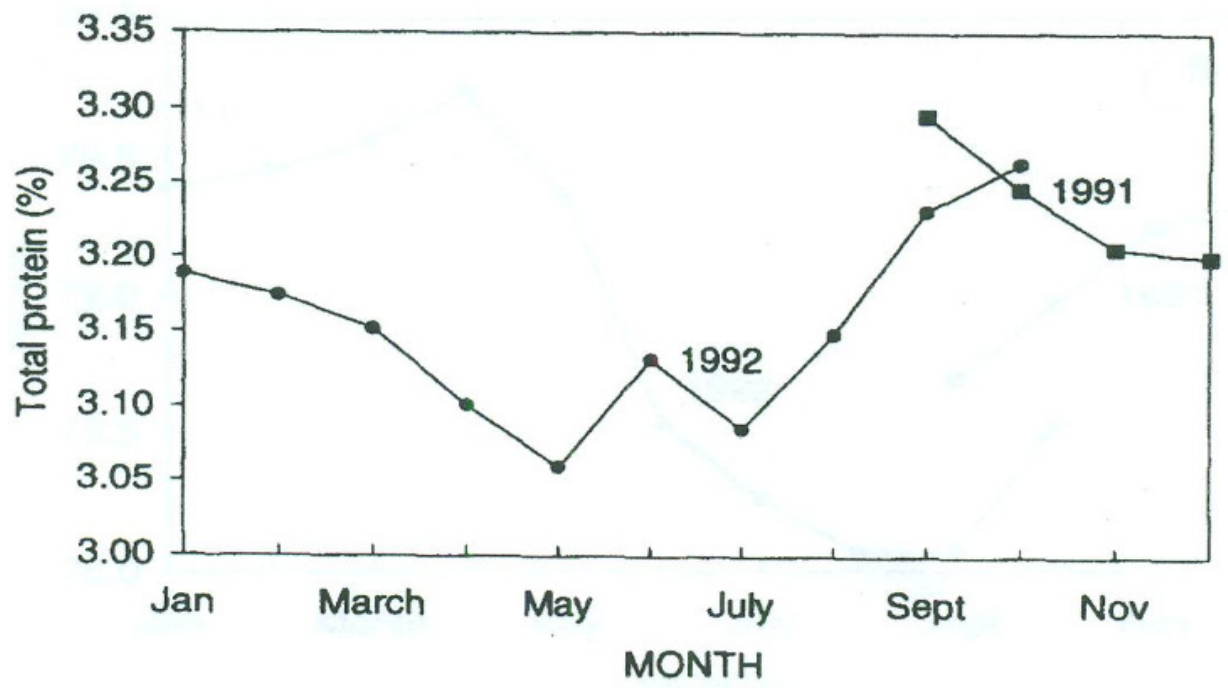

Figure 8. Variations of total protein in milk (average of seven Quebec cheese plants) (Taken from Lacroix et al. 1996) 


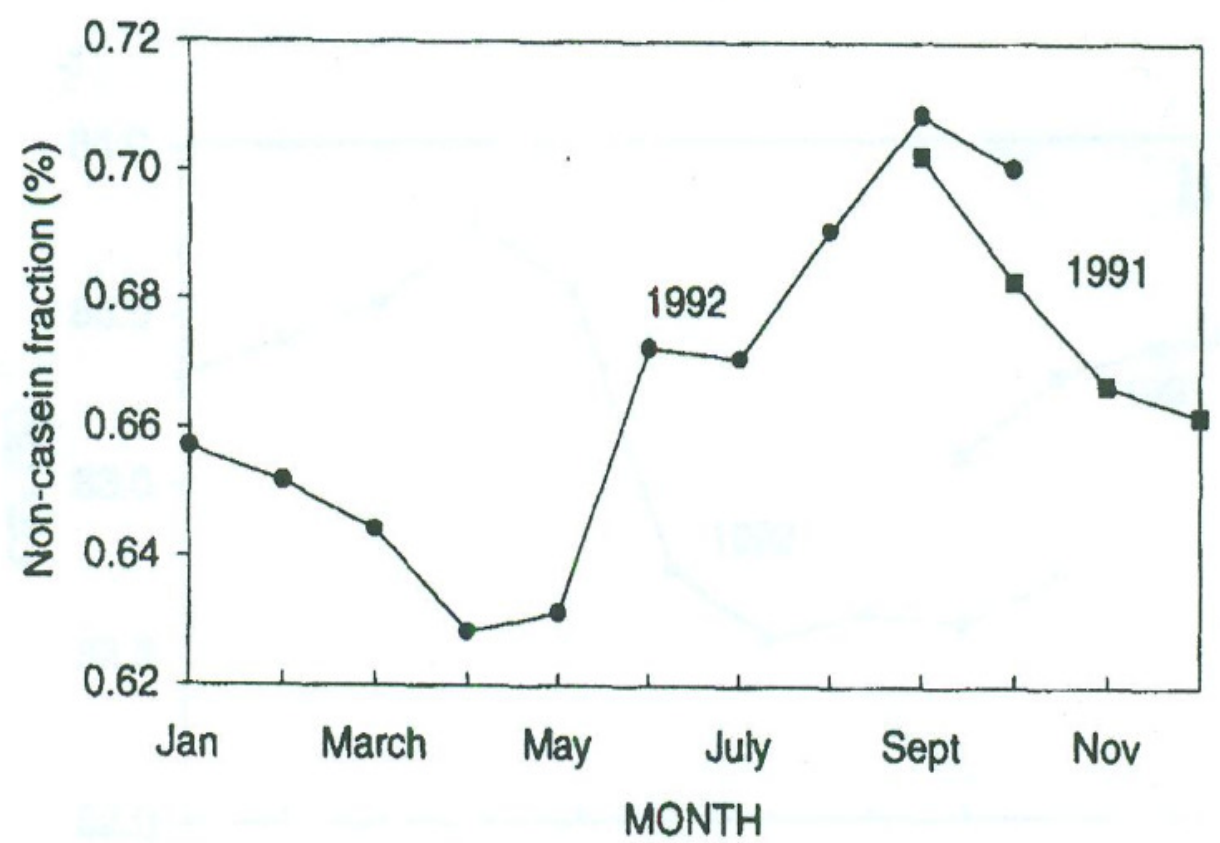

Figure 9. Variations of non-casein fraction in milk (average of seven Quebec cheese plants (Taken from Lacroix et al. 1996)

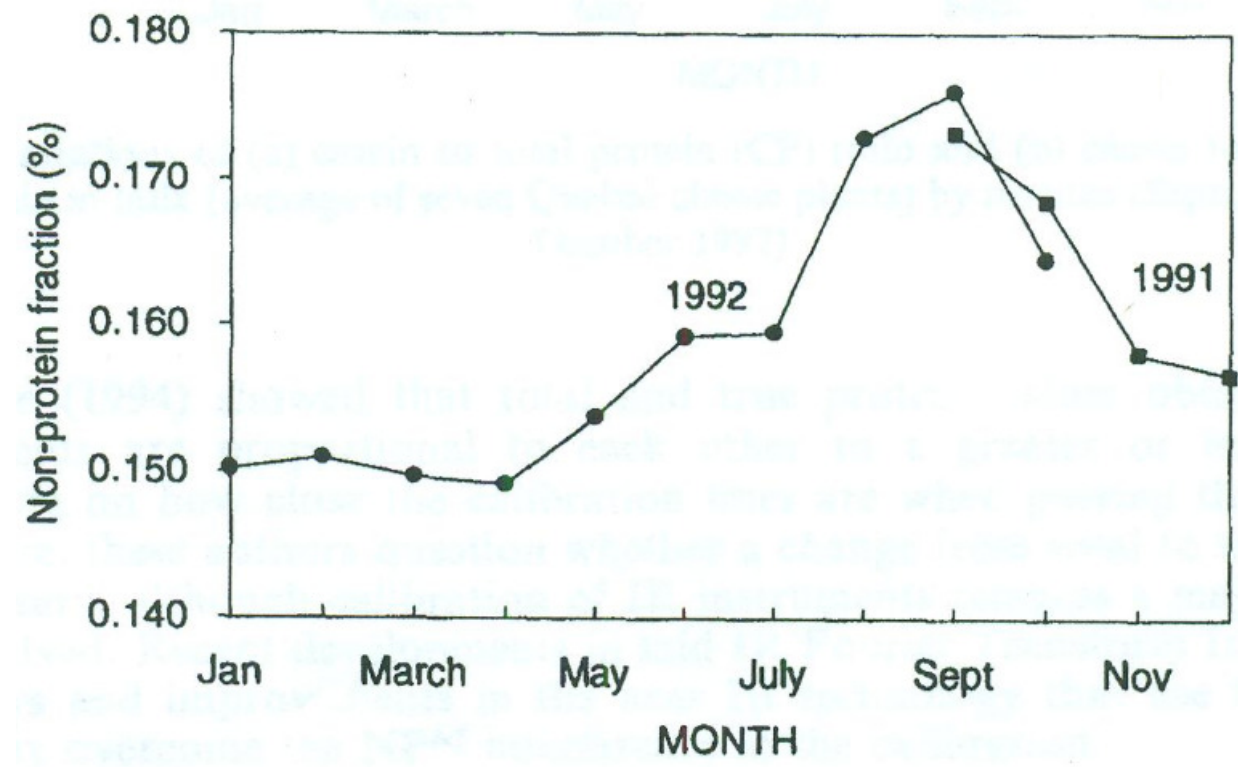

Figure 10. Variations of non-protein fraction in milk (average of seven Quebec cheese plants) (Taken from Lacroix et al. 1996) 


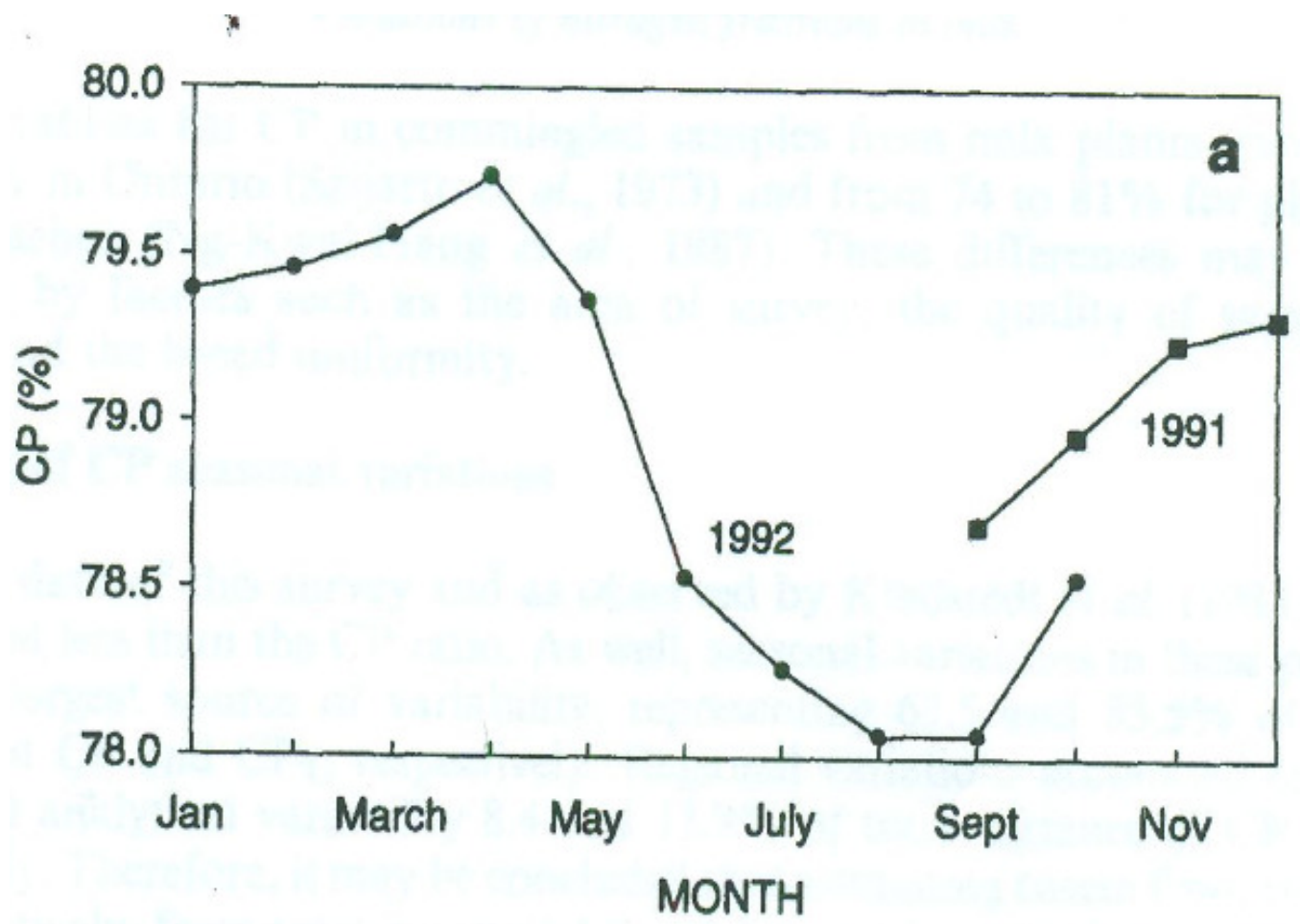

Figure 11. Variation of casein to total protein (CP) ratio (Taken from Lacroix et al. 1996)

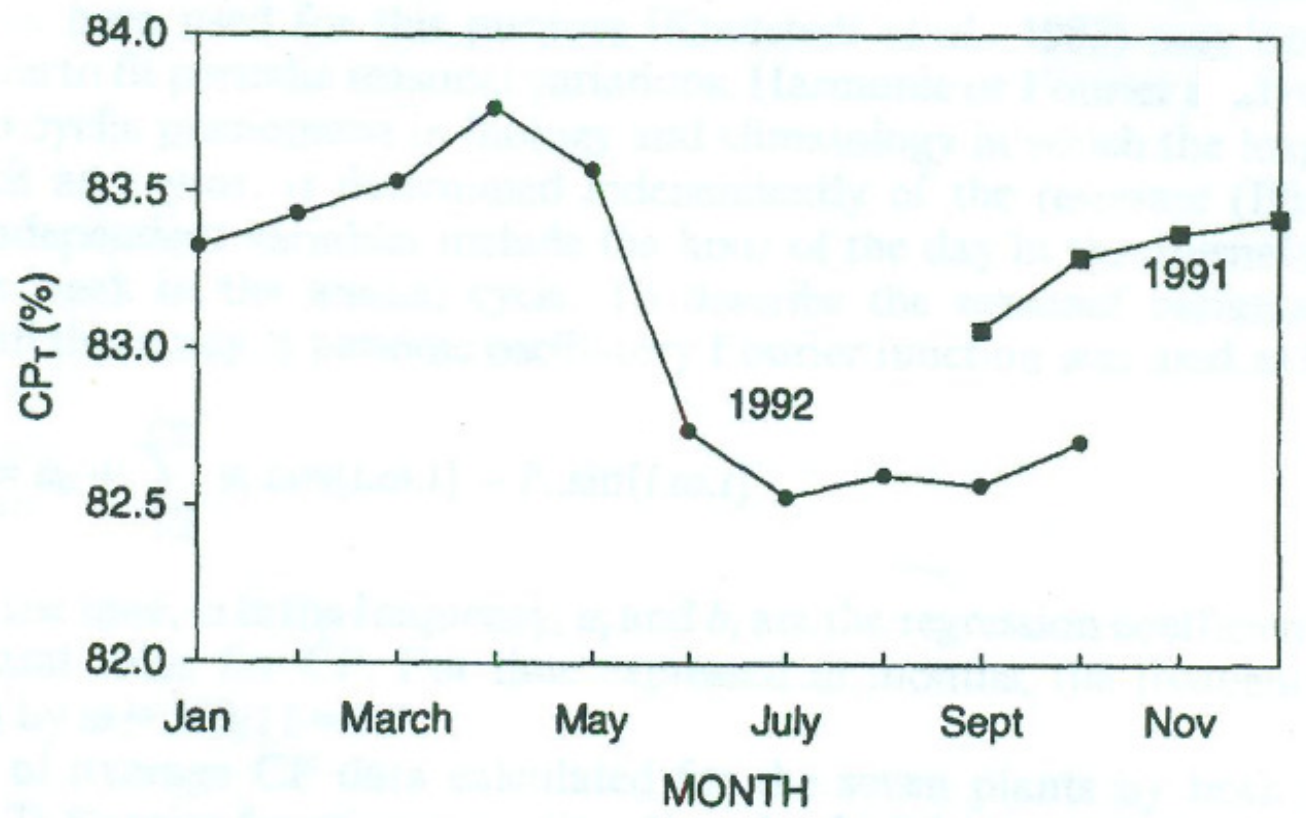

Figure 12. Variation of casein to true protein (CPt) ratio (Takenfrom Lacroix et al. $\underline{1996)}$ 
Table 4. Seasonal variation of casein to total protein ratio (Taken from Lacroix et al., 1996)

\begin{tabular}{|c|c|c|c|c|c|c|}
\hline Sampling & $\begin{array}{l}\text { Country or } \\
\text { region }\end{array}$ & $\begin{array}{l}\text { Length of } \\
\text { study }\end{array}$ & $\begin{array}{l}\text { Mean } \\
\text { CP }(\%)\end{array}$ & Maximum & Minimum & References \\
\hline 6 plants & California & 20 months & 76.71 & Dec & Sept & $\begin{array}{l}\text { Nickerson } \\
\text { (1960) }\end{array}$ \\
\hline 1 plant & Friesland & 3 years & 76.11 & Jan & Mar & $\begin{array}{l}\text { Ter Horst } \\
\text { (1963) }\end{array}$ \\
\hline 9 plants & $\begin{array}{l}\text { Holland } 1 \\
\text { year }\end{array}$ & 1 year & 77.9 & Dec-Jan & Sept-Oct & $\begin{array}{l}\text { Posthumus et } \\
\text { al., (1964) }\end{array}$ \\
\hline 2 herds & England & 2 years & 76.02 & May & Jul-Aug & $\begin{array}{l}\text { Burton } \\
(1967)\end{array}$ \\
\hline 3 herds & Australia & 18 months & 76.66 & Aug & June & $\begin{array}{l}\text { Tucker } \\
\text { (1969) }\end{array}$ \\
\hline 15 regions & Sweden & 5 years & 78.43 & Nov-Feb & Sept & $\begin{array}{l}\text { Joost et al. } \\
(1973)\end{array}$ \\
\hline 24 plants & Ontario & 1 year & 74.76 & Nov-Feb & Sept - Oct & $\begin{array}{l}\text { Szijarto et al. } \\
(1973)\end{array}$ \\
\hline 17 plants & $\begin{array}{l}\text { England- } \\
\text { Wales }\end{array}$ & 23 years & 76.13 & Dec-Jan & $\begin{array}{l}\text { Aug - } \\
\text { Sept }\end{array}$ & $\begin{array}{l}\text { Harding \& } \\
\text { Royal (1974) }\end{array}$ \\
\hline 1 herd & $\begin{array}{l}\text { The } \\
\text { Netherlands }\end{array}$ & 11 months & 75.0 & Mar & Oct & $\begin{array}{l}\text { De Koning et } \\
\text { al. (1974) }\end{array}$ \\
\hline 5 plants & $\begin{array}{l}\text { The } \\
\text { Netherlands }\end{array}$ & 3 years & 76.7 & Mar & Jul -Aug & $\begin{array}{l}\text { Lolkema } \\
\text { (1978) }\end{array}$ \\
\hline 2 plants & Scotland & 1 year & 82.44 & Oct - Nov & $\begin{array}{l}\text { Aug - } \\
\text { Sept }\end{array}$ & $\begin{array}{l}\text { Davies \& } \\
\text { Law(1980) }\end{array}$ \\
\hline 3 plants & Ireland & 1 year & 74.83 & Aug & Dec & $\begin{array}{l}\text { Phelan } \\
\text { (1981) }\end{array}$ \\
\hline $\begin{array}{l}2800 \text { cows } \\
\text { from } 63 \\
\text { herds }\end{array}$ & Quebec & 17 months & 79.77 & Feb & Jan & $\begin{array}{l}\text { Ng-Kwai- } \\
\text { Hang et al. } \\
(1982)\end{array}$ \\
\hline 7 plants & Vermont & 11 months & 77.47 & Apr & Aug & $\begin{array}{l}\text { Kindstedt et } \\
\text { al. (1983) }\end{array}$ \\
\hline $\begin{array}{l}115 \text { farms } \\
\text { from one }\end{array}$ & New York & 2 years & 77.02 & Nov & May & $\begin{array}{l}\text { Verdi et al. } \\
\text { (1987) }\end{array}$ \\
\hline 13 plants & Quebec & 15 months & 76.1 & $\mathrm{Feb}$ & Dec & $\begin{array}{l}\text { Ng-Kwai- } \\
\text { Hang et al. } \\
\text { (1987) }\end{array}$ \\
\hline 4 regions & California & 1 year & 76.4 & NO & NO & $\begin{array}{l}\text { Franke et al. } \\
\text { (1988) }\end{array}$ \\
\hline 10 regions & USA & 1 year & 78.15 & Dec-Jan & Jul- Sept & $\begin{array}{l}\text { Barbano } \\
(1990)\end{array}$ \\
\hline 7 regions & Quebec & 14 months & 78.92 & Apr & Jul-Sept & $\begin{array}{l}\text { Lacroix et al. } \\
\text { (1996) }\end{array}$ \\
\hline
\end{tabular}




\section{7.b. Studies on Seasonal Variation of Milk Composition in California}

In California, the seasonal variation in milk composition is thought to be minimal because of the large herd sizes, constant production of milk maintained by having equal number of cows freshen up each month, and feeding in dry lot throughout the year (alfalfa and grain in proportion to production). Herds are also monitored regularly by analyzing their milk for fat, protein, and lactose for payment by using Infra-Red Analyzer (Bruhn \& Franke, 1977). However, few studies have reported some seasonal changes in the milk composition, and it is briefly discussed below.

Nickerson (1960) collected bulk milk samples from six processing plants in different areas in California (Visalia, Newman, Davis, Willows, Petaluma, and Fernbridge). The samples were collected over a nine-month period (June 1955 to October 1956) and analyzed for 23 milk components. He reported significant compositional difference among the bulk milk samples, both seasonally and within areas. He observed that 18 of 23 components, which include total solids, fat, SNF, total nitrogen, casein, and total calcium varied significantly. Only proteose-peptone and non-protein nitrogen, two minor phosphorus compounds, and soluble calcium failed to vary with season. He also noticed that the milk that had the lowest average protein content also had the lowest calcium and magnesium levels and vice versa. Most constituents that varied were lowest in May through July and highest in November through January.

Frank et al. (1987) studied the suitability of California raw milks for the production of cheese during 1983 by measuring the distribution of nitrogen of farm milk from four major dairy regions in California. The four regions are North Bay, L.A. Basin, S. San Joaquin Valley, and North West Coast. Though they observed a regional difference in 
total protein and protein fractions, they found that there was no significant variation of protein or its fraction with season in all the four regions.

Bruhn \& Franke (1991) compiled the milk composition and cheese yield data from four dairy plants in California for two years (1987 and 1988). The samples were analyzed for protein, fat, and solid not fat using infra-red analyzer. Protein, fat and solid not fat were higher in winter and lower in summer months (Table 5). They noted that the trend observed in this study were similar to that observed in Quebec.

Table 5. Composition of milk received by four California cheese plants (Taken from Bruhn \& Franke, 1991)

\begin{tabular}{llllllllll}
\hline Month & \multicolumn{3}{c}{ Milk Fat } & \multicolumn{3}{c}{ Protein } & \multicolumn{3}{c}{ Solids-not-fat } \\
\cline { 2 - 9 } & $\mathbf{1 9 8 7}$ & $\mathbf{1 9 8 8}$ & Overall & $\mathbf{1 9 8 7}$ & $\mathbf{1 9 8 8}$ & Overall & $\mathbf{1 9 8 7}$ & $\mathbf{1 9 8 8}$ & Overall \\
\hline January & 3.99 & 4.07 & 4.03 & 3.33 & 3.38 & 3.36 & 8.89 & 8.86 & 8.88 \\
February & 3.93 & 3.96 & 3.94 & 3.27 & 3.31 & 3.29 & 8.82 & 8.80 & 8.81 \\
March & 3.87 & 3.84 & 3.85 & 3.29 & 3.27 & 3.28 & 8.85 & 8.79 & 8.82 \\
April & 3.74 & 3.75 & 3.75 & 3.27 & 3.23 & 3.25 & 8.85 & 8.75 & 8.80 \\
May & 3.70 & 3.75 & 3.73 & 3.21 & 3.22 & 3.22 & 8.77 & 8.72 & 8.75 \\
June & 3.70 & 3.70 & 3.70 & 3.19 & 3.21 & 3.20 & 8.73 & 8.67 & 8.70 \\
July & 3.72 & 3.67 & 3.70 & 3.21 & 3.19 & 3.20 & 8.74. & 8.68 & 8.71 \\
August & 3.75 & 3.67 & 3.71 & 3.22 & 3.18 & 3.20 & 8.74 & 8.60 & 8.67 \\
September & 3.80 & 3.77 & 3.79 & 3.29 & 3.24 & 3.27 & 8.77 & 8.70 & 8.73 \\
October & 3.85 & 3.83 & 3.84 & 3.32 & 3.33 & 3.32 & 8.79 & 8.76 & 8.77 \\
November & 3.97 & 3.88 & 3.93 & 3.50 & 3.42 & 3.46 & 8.86 & 8.84 & 8.85 \\
December & 4.08 & 4.00 & 4.04 & 3.41 & 3.45 & 3.43 & 8.89 & 8.89 & 8.89 \\
Annual & 3.84 & 3.82 & 3.83 & 3.29 & 3.29 & 3.29 & 8.81 & 8.75 & 8.78 \\
mean & & & & & & & & & \\
Minimum & 3.70 & 3.67 & 3.67 & 3.19 & 3.18 & 3.18 & 8.73 & 8.60 & 8.60 \\
Maximum & 4.08 & 4.07 & 4.08 & 3.50 & 3.45 & 3.50 & 8.89 & 8.89 & 8.89 \\
\hline
\end{tabular}

Laben (1963) has mentioned in his review that three years of records from a high-

producing herd of 300 cows in the California milk composition study showed distinct differences in seasonal trend of SNF content between years. The summer tests for 1961 failed to show a down-ward trend whereas the 1960 and 1962 tests showed definite drops 
in SNF tests from June through August. Milk fat test showed an almost identical fluctuation of winter peaks and summer depressions all three years.

Bruhn \& Franke (1977) studied the variation of gross composition of milk due to breed differences and environmental conditions from 1974 to 1975 in California. They collected milk from 15 herds, which comprised 4 breeds in the San Joaquin Valley where the average day-time temperature in summer was $37^{\circ} \mathrm{C}$ and winter was $13^{\circ} \mathrm{C}$. The night variation was $20^{\circ} \mathrm{C}$ in summer and $11^{0} \mathrm{C}$ in winter. They analyzed the milk composition using infra-red analyzer. The shorthorn breeds produced significantly less fat than other herds. Holstein produced milk with less fat than Jersey and Guernsey herds. The Shorthorn and Holstein produced significantly less protein than Guernsey and Jersey herds. In addition, the fat and protein content concentration for all herds were significantly lower from May through August and higher from November through February (Figure 13 and Figure 14). 


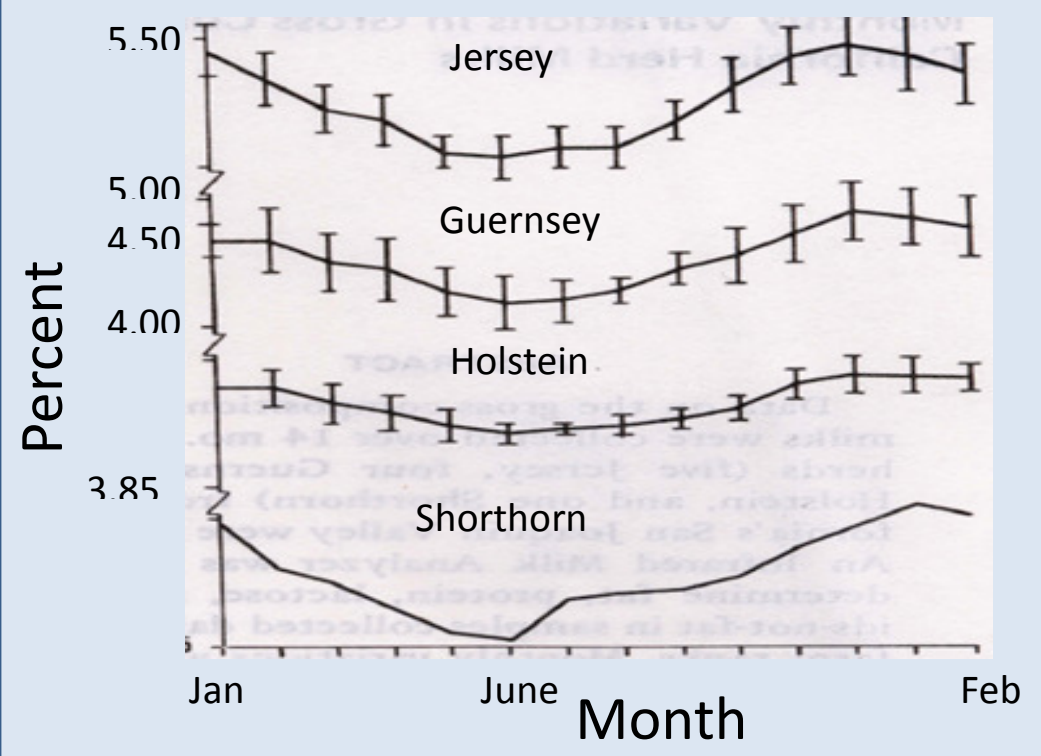

Figure 13. Monthly variation of fat from four breeds in California (1974-1975) (Adapted from Bruhn \& Franke, 1977)

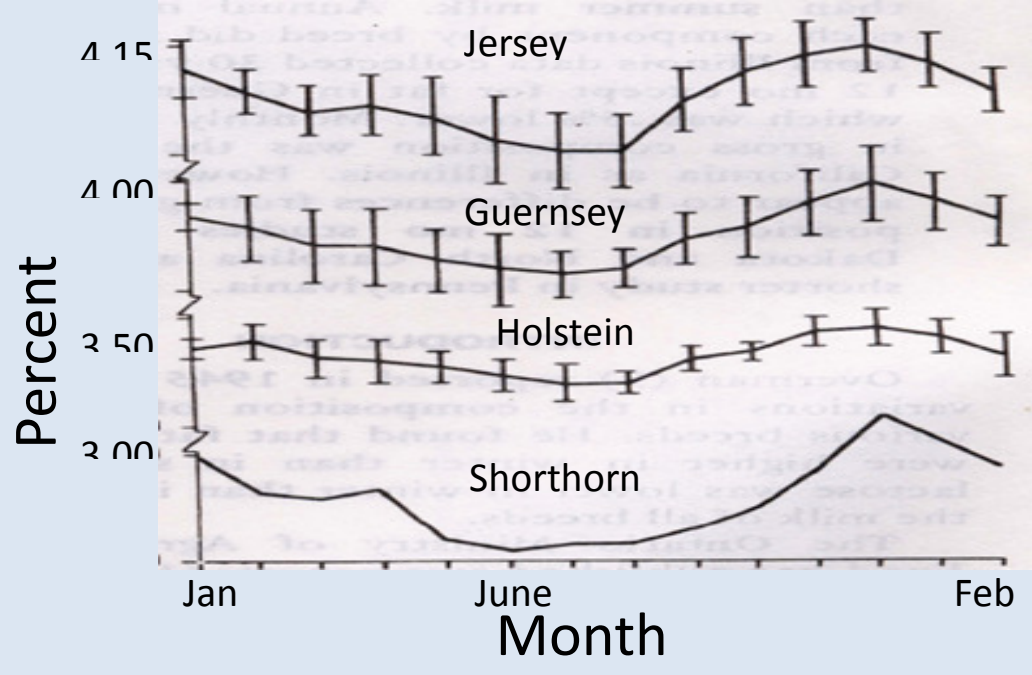

Figure 14. Monthly variation of protein from four breeds in California (1974 -1975) $\underline{\text { (Adapted from Bruhn \& Franke, 1977) }}$ 


\section{E. Low Moisture Part Skim (LMPS) Mozzarella}

Mozzarella, originally made from buffalo milk in Italy, is one of the prominent members in the pasta-filata cheese. Pasta-filata cheeses are made by plasticizing and kneading fresh curd in hot water, which reorganizes into a unidirectional fibrous structure (Kindstedt et al., 2004). When Italian cuisine, especially pizza, became popular in the U.S, mozzarella began gaining importance. In 1985, 75\% of all Mozzarella produced in the US was used for pizza (Kindstedt, 1999). In 2010, 2.5 billion kg of Italian cheeses were sold around the word and U.S accounts for about $2 / 3^{\text {rd }}$ of global mozzarella production. Most of the Mozzarella produced in the U.S. is targeted for the food service industry (Jones G.M, 2011).

Mozzarella cheese is divided into four separate categories defined by standards of identity in Code of Federal Regulation. It is categorized on the basis of moisture content and fat in dry matter (FDM) as indicated in Table 6. Mozzarella and part skim mozzarella have high moisture content and are soft bodied thereby shred poorly, clump together more, and have a limited shelf life. Hence, these varieties of Mozzarella are mostly consumed as table cheese and are not used often in food service as an ingredient for pizza. In contrast, low moisture and low moisture part skim Mozzarella have much lower water content (typically 47-48\%), longer shelf life, and firmer body. These properties impart good shredding and matting properties, and therefore, are used primarily as ingredients for pizza and related foods (Kindstedt, 1999). A FDM of $45 \%$ is a critical for the meltability and free oil release of Mozzarella (Rankin et al., 2006). During melting, initial heat causes relaxation of the protein - protein bonds, which increases the movement of casein strands and eventual collapse of the casein matrix, allowing fat to 
leak out and coalesce. As the temperature rises further, hydrophobic interactions between casein molecules increase causing the casein network to shrink. This shrinkage of the main framework pushes out water and liquid fat. Studies have reported a biphasic relationship between meltability and FDM. In fact, changes from 18\% to 45\% FDM have a little increase on melt properties, but a change above $45 \%$ FDM causes a rapid increase in meltability. At 45\% FDM, the density of casein network reaches a point where the solid to liquid ratio influences melt and the ability for casein to hold liquid fat (Rankin et al. 2006). Hence, mozzarella with different moisture and FDM content is made to suit customers' functionality and requirement.

Table 6. Compositional standards for mozzarella in United States (Adapted from Code of Federal Regulation (CFR) 133.155 to 133.158)

\begin{tabular}{lcc}
\hline Type & Moisture (\%) & Fat in Dry Matter (\%) \\
\hline Mozzarella & $>52$ but $\leq 60$ & $\geq 45$ \\
Low -moisture & $>45$ but $\leq 52$ & $\geq 45$ \\
Low moisture part skim & $>45$ but $\leq 52$ & $\geq 30$ but $<45$ \\
Part-Skim & $>52$ but $\leq 60$ & $\geq 30$ but $<45$ \\
\hline
\end{tabular}

\section{F. Manufacturing of Low Moisture Part Skim (LMPS) Mozzarella}

LMPS Mozzarella is manufactured from partially skimmed milk that contains about $2 \%$ milk fat. In the United States, its fat content can be from $30 \%$ to $45 \%$ on a dry basis (FDB), and its moisture content can be from 45\% to 52\%. As LMPS Mozzarella is mainly used in pizza, it is manufactured to meet mainly the heated functional properties (melt, flow, and browning) specified by each pizza company. However, "string cheese" is one exception in which LMPS Mozzarella is hot extruded with a diameter of about 
$1.5 \mathrm{~cm}$, brined, cut into finger-length pieces, and packaged as individually wrapped pieces. It is a popular snack and generally consumed cold (McMahon \& Oberg, 2011). Traditionally, manufacture of low moisture Mozzarella is quite similar to that of cheddar, with some notable changes. To compensate for the variation of milk composition, the milk is standardized to ensure that manufactures meet the required levels of fat in dry matter and moisture content. The milk is standardized to a casein-to-fat ratio of about 1.2 by removing cream or by adding solids in the form of liquid or dried skim milk concentrate (McMahon \& Oberg, 2011). The standardized milk is pasteurized, inoculated with starter culture, and then pumped into enclosed vats (Figure 15) (Rankin et al., 2006).

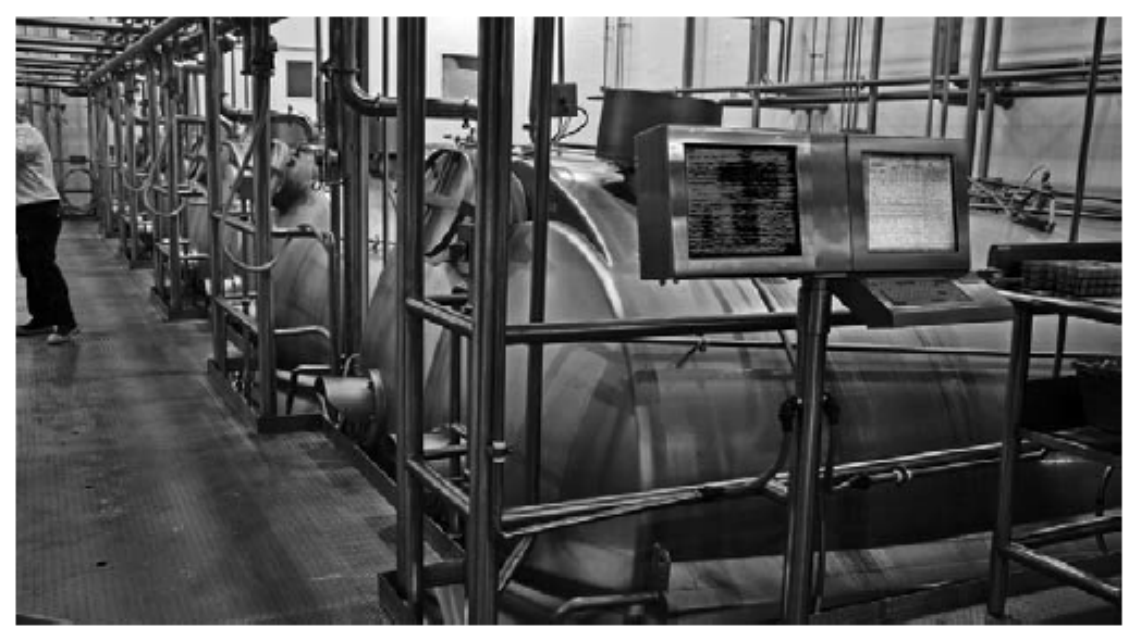

Figure 15. Large scale manufacture of LMPS Mozzarella cheese in enclosed vats $\underline{\text { Taken from McMahon \& Oberg, 2011) }}$

Starter culture used can be mesophillic (e.g., Lactococcus lactis ssp. lactis, cremoris) or thermophilic starter culture, which comprises Streptococcus salavarius ssp. thermophilus in combination with Lactobacillus delbrueckii ssp. bulgaricus or Lactobacillus helveticus (Kindstedt et al., 2004). Chemical acidification instead of starter cultures is done for mozzarella used as table cheeses where high moisture content of $55 \%-60 \%$ is required. 
Chemical acidification is not used extensively for making low moisture Mozzarella (McMahon \& Oberg, 2011). Usually, thermophilic starters are used in the production of low moisture part skim mozzarella. As this cheese has a mild flavor, the main function of the starter is to produce lactic acid, which will solubilize the casein associated calcium so that the curd will melt and stretch in hot water to give the desired texture and functional properties. Then inoculated cheese milk is coagulated with rennet. Since thermophilic cultures are used for LMPS Mozzarella, the milk is set at about $35^{\circ} \mathrm{C}(\mathrm{McMahon} \&$ Oberg, 2011). Before the rennetting process, calcium chloride may be added to enhance rennet properties, namely reduce the gelling time, and increase curd firmness. The amount of calcium chloride depends on the quality of milk (Rankin et al., 2006). However, addition of calcium chloride $40 \%$ (w/w) was found to cause weeping, water loss, reduction in $\mathrm{pH}$, and a more aggregated para casein matrix. This indicates that calcium addition reduces the casein hydration and hence reduces the levels of moisture and impacts the texture of mozzarella (Guinee \& Fox, 2004). 


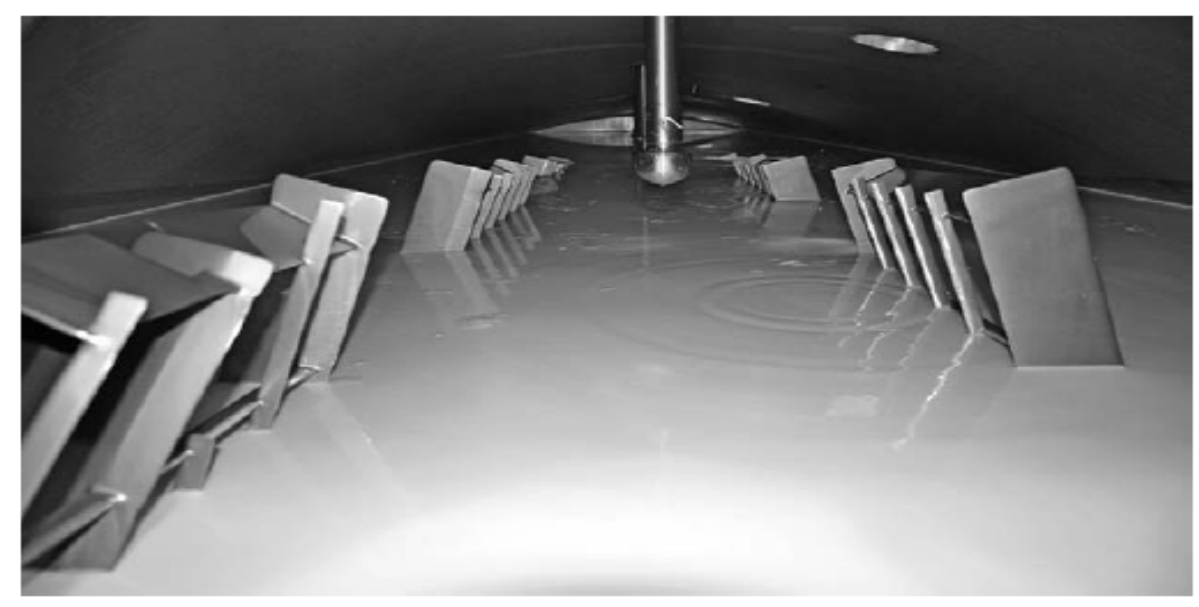

Figure 16. Curd formation after rennetting of milk inside an enclosed vat (Adapted from McMahon \& Oberg, 2011)

The set curd (Figure 16) is cut to 2 inch pieces, stirred, and heated to about $40^{\circ} \mathrm{C}$. At $\mathrm{pH}$ 6.2-6.3, it is pumped to a large enclosed conveyor belt system (Figure 17) where the whey is drained, and the curd is stirred until a $\mathrm{pH}$ of 5.1 to 5.4 is reached (McMahon \& Oberg, 2011).

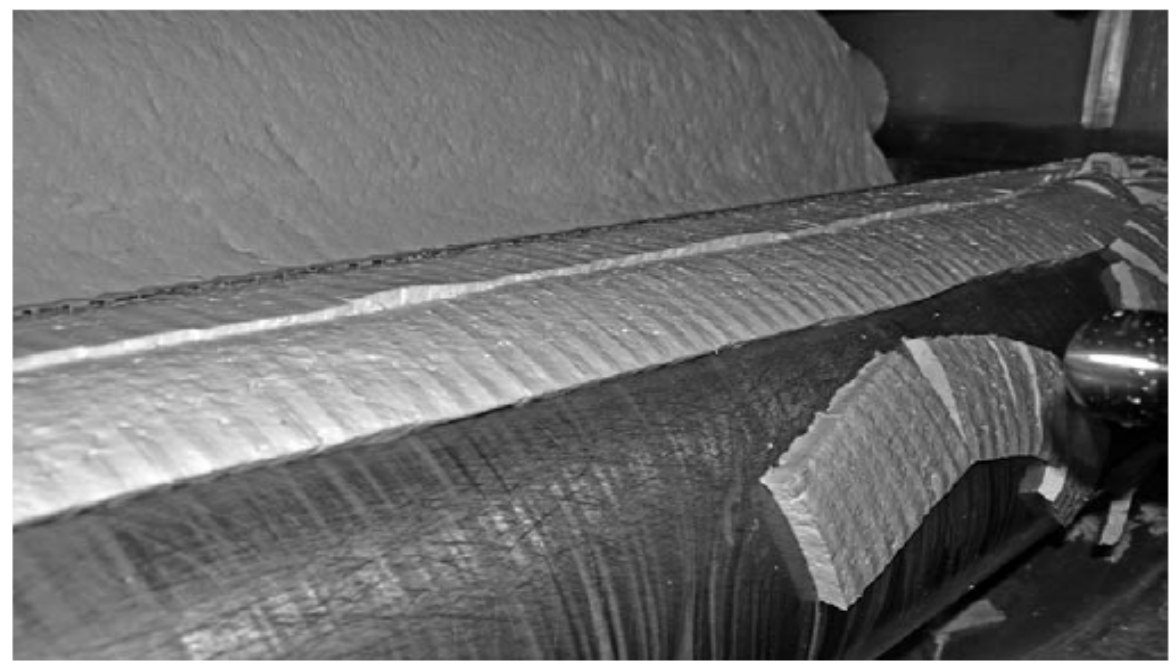

Figure 17. Curd mass cut into pieces as it exits the draining, matting and cheddaring belt (Taken from McMahon \& Oberg, 2011)

If salting of the curd is done at this step, the curd is removed at a slightly higher $\mathrm{pH}$, and salt is added. The milled curds, unsalted, partially salted or salted, are stretched 
mechanically in hot brine or hot water and mechanically worked in a cooker/stretching machine to produce the plastic consistency characteristic of pasta-filata cheeses (McMahon \& Oberg, 2011). In an industry, stretching and plasticization is usually done in a two-step process. In the first step, the curd enters a reservoir of hot water at the front of the mixer where the curd temperature increases to $50^{0}-55^{0} \mathrm{C}$. The curd at this temperature is transformed into a plastic workable consistency. In the second stage, the plasticized curd is kneaded and stretched by single or twin-screw augers as shown in Figure 18 (Kindstedt et al., 2004).

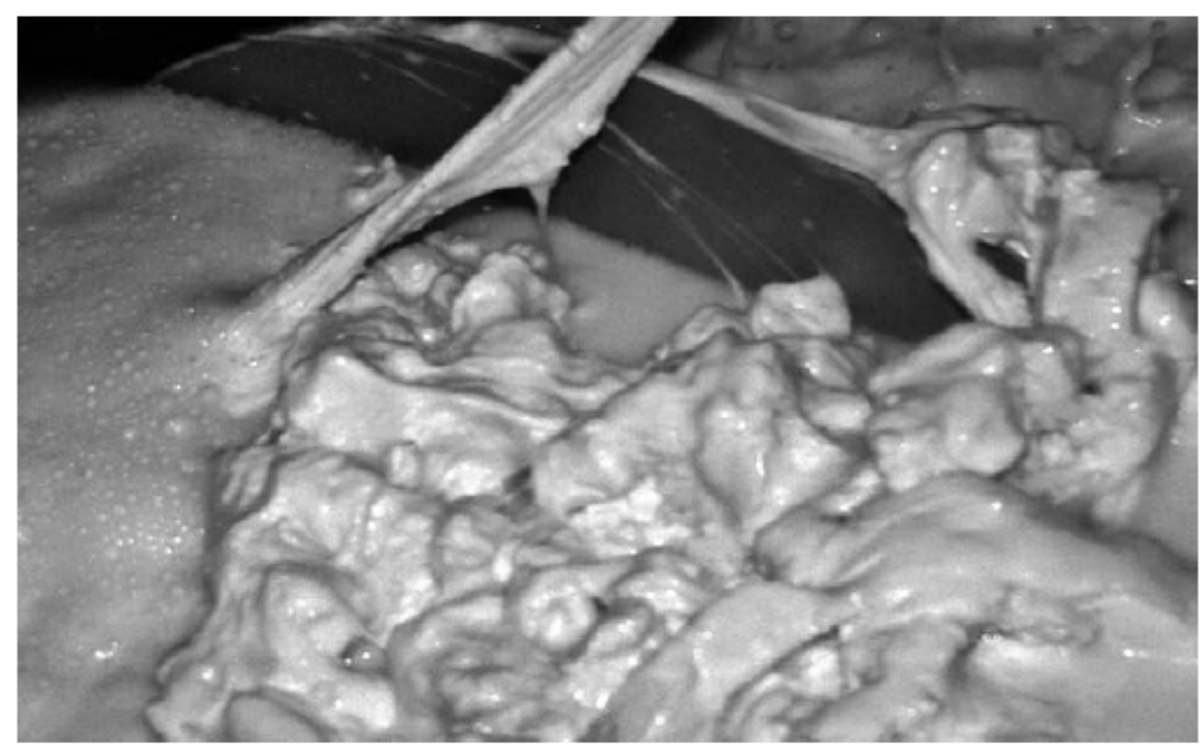

Figure 18. Curd being mechanically stretched in hot water (Taken from McMahon \& Oberg, 2011)

Cheese exits the cooker/stretcher at about $55^{0}-65^{0} \mathrm{C}$ as a smooth plastic mass (Figure 19) with a fibrous structure. 


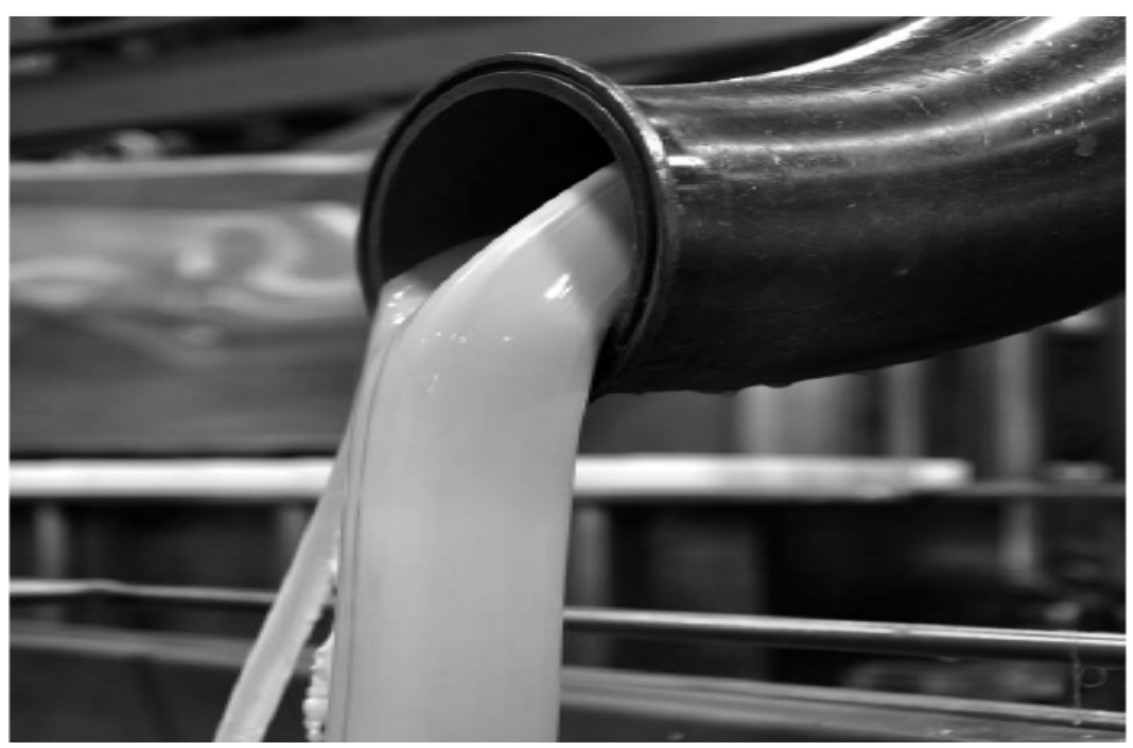

\section{Figure 19. Hot mass exiting the cooker/stretcher (Taken from McMahon \& Oberg,} 2011)

The hot mass of cheese is either filled under pressure into molds (Figure 20) or extruded as a continuous ribbon, which is cooled in cold water, cold brine, or in a cooling tunnel. Dry salt can be added before stretching or as hot cheese mass exits the cooker/stretcher, or $5-10 \%$ hot brine solution is used as a part of the stretching process. Mechanization of the cheese making process allows virtually any shape of block to be formed (Kindstedt et al., 2004). The cheese blocks can also be cooled and then salted in a cool 5-10\% brine solution (Figure 21). Then the cheese block is dried and vacuum packaged (McMahon \& Oberg, 2011). 


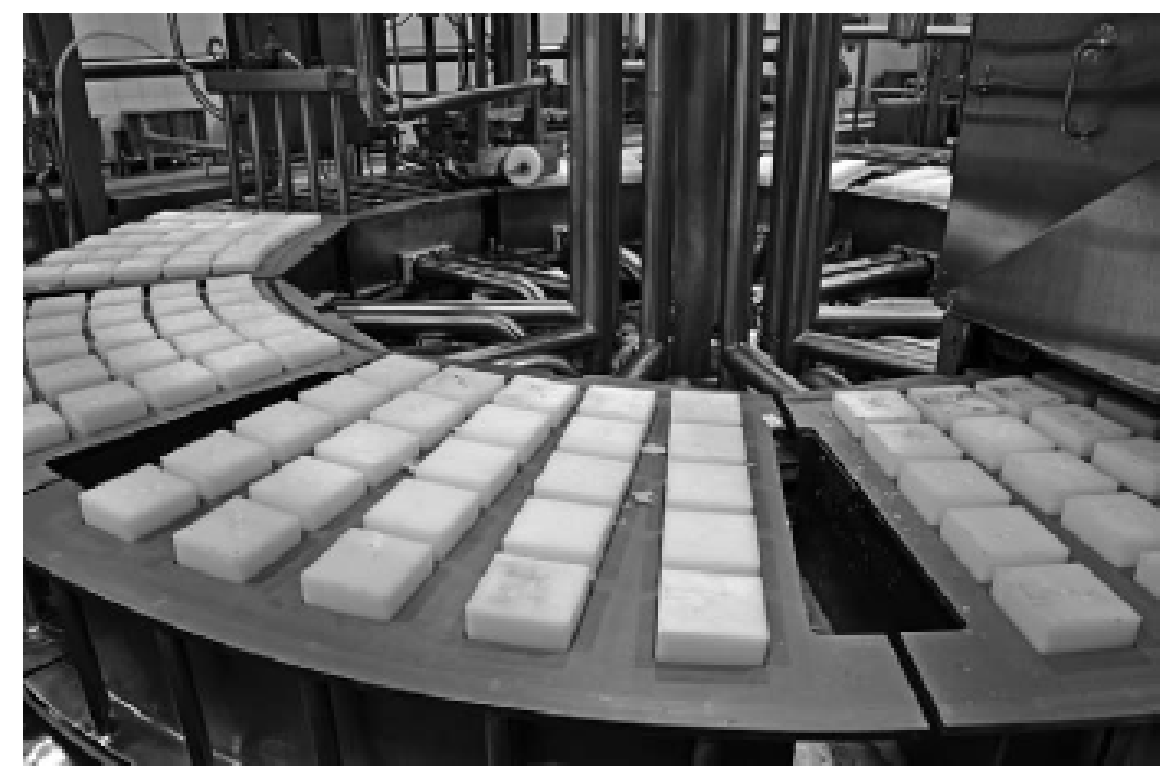

Figure 20. Mechanical molding of hot cheese into rectangular blocks (Taken from McMahon \& Oberg, 2011)

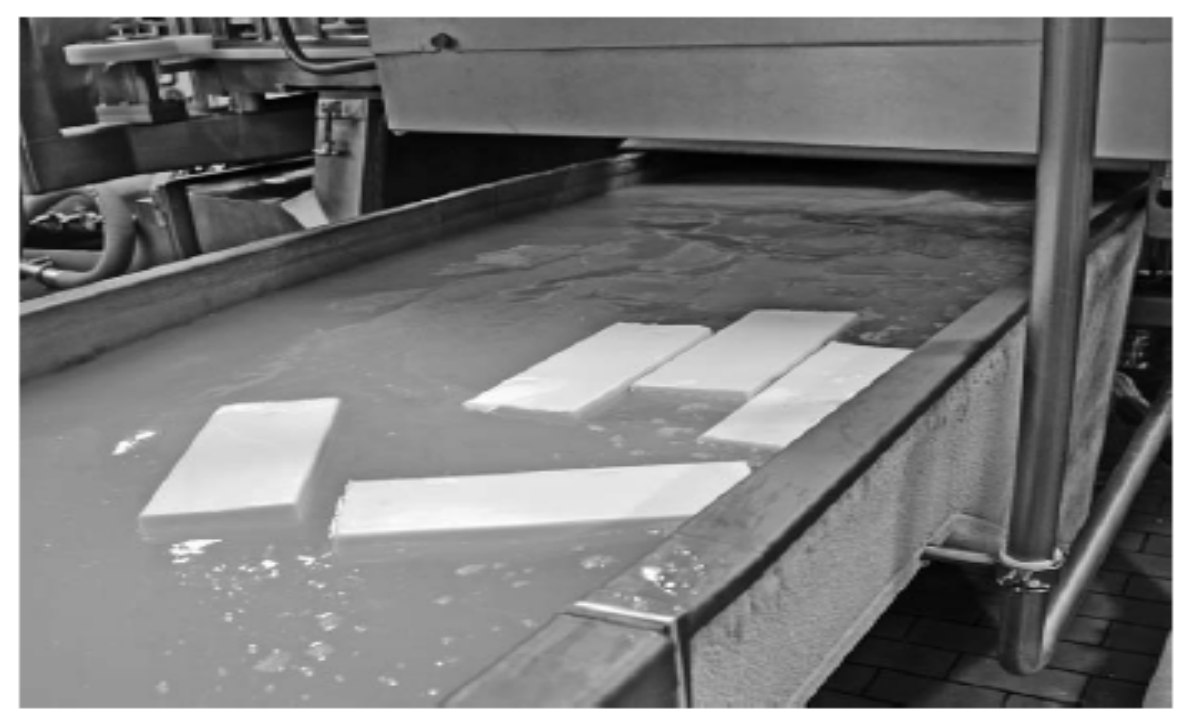

Figure 21. Blocks of LMPS mozzarella entering the brining tank (Taken from McMahon \& Oberg, 2011)

\section{G. Characteristics of LMPS Mozzarella Cheese Structure}

Milk, which is a fluid suspension of fat globules and casein micelles, is converted into coagulum by aggregation casein micelles. This clumping of casein micelles occurs due to 
addition of rennet and lowering of the $\mathrm{pH}$. Cutting and stirring of the coagulum with a drop in $\mathrm{pH}$ causes the whey to ooze out, and the curd shrinks. When the curd is stretched under heat, the curd transforms from an open-celled structure consisting of a network of protein strands, containing interspersed serum and fat globules (Figure 22), into parallel fibrous protein fibers separated by long channels of accumulated fat and free serum (Figure 23). During stretching/cooking, as the curd melts and is mechanically mixed, the protein strands fuse together except at places where fat and moisture are present. After the protein strands cool, the channels separating the protein fibers are filled with closepacked fat globules. When fat is removed from mozzarella cheese, the protein strands fuse together to a homogenous mass due to less serum phase (McMahon \& Oberg, 2011).

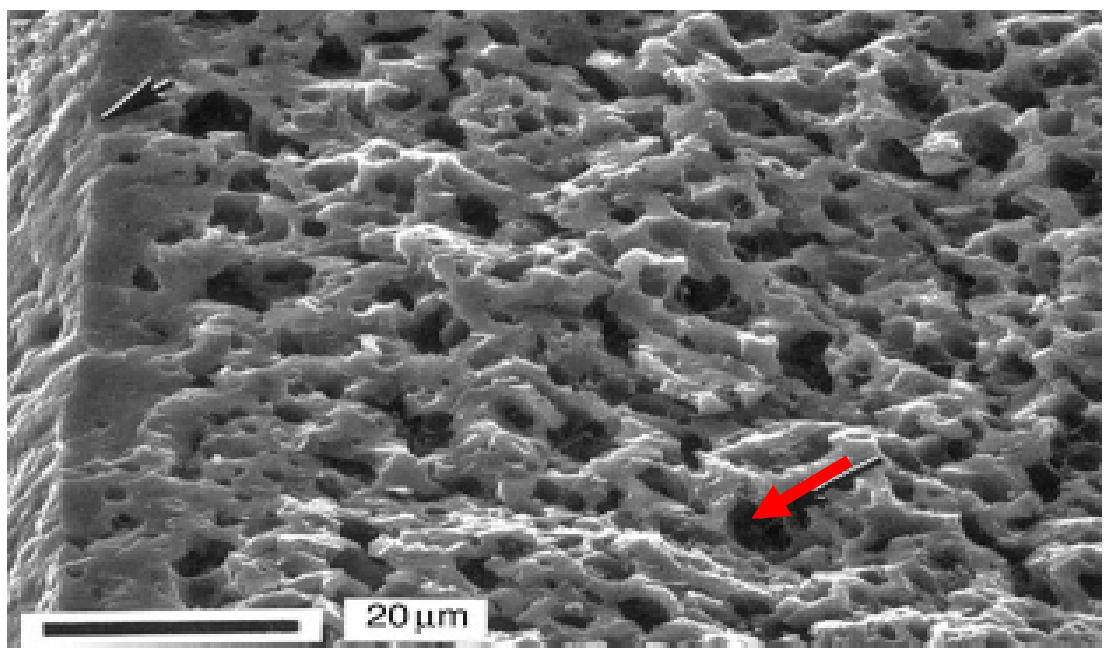

Figure 22. Scanning electron micrograph of curd after whey is drained (Taken from McMahon \& Oberg, 2011).

In Figure 22, the small arrow indicates cavities in which fat globules and serum were removed during sample preparation. 


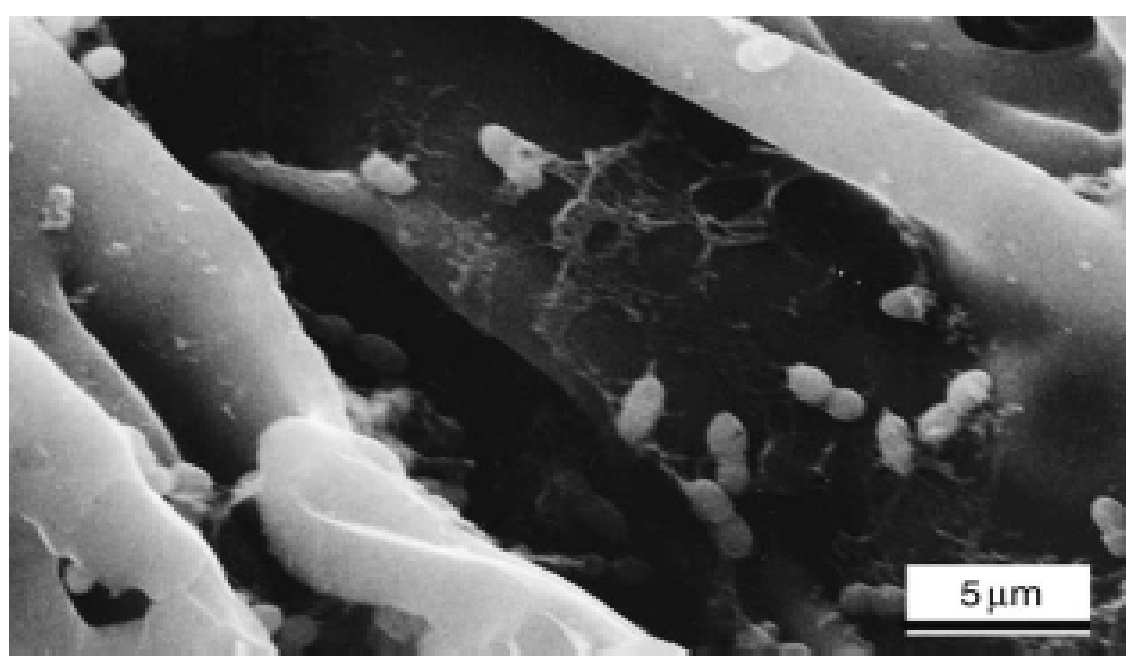

\section{Figure 23. Scanning electron micrograph of hot LMPS mozzarella after stretching (Taken from McMahon \& Oberg, 2011).}

In Figure 23, the formation of protein network into parallel strands separated by serum channels is shown. The black spaces in Figure 23 represent the fat globules and serum phases that were removed during sample preparation. The physical properties of Mozzarella like texture, meltability, stretchability, and color are affected by initial cheese milk composition, manufacturing protocol, and ripening conditions. The most important factors influencing these properties are the amount of casein, fat moisture, and calcium associated with casein, interaction between and within molecules, and the extent of proteolysis. These are in turn influenced by various other conditions such as $\mathrm{pH}$ development, temperature, and ionic strength (Lucey et al., 2003, and McMahon \& Oberg, 2011). Fat-serum interrupts the para-casein fibers, and the amount of fat influences the initial structure and gives softness to LMPS Mozzarella especially when heated. As fat content decreases, the casein strands become thicker with little fat-serum pools between them. This makes the cheese rubbery and very firm (Kindstedt et al., 2004). 
The casein-associated calcium influences the ability of the curd to plasticize in hot water and reorganize into a unidirectional fibrous structure when stretched. The total calcium of the curd and distribution of the calcium between the soluble and insoluble states plays an important role during stretching. Too much casein associated calcium makes the curd tougher curd, and it fractures easily during stretching whereas too little calcium results in a softer curd and during stretching it becomes fluid-like due to complete loss of structure (Kindstedt et al., 1999).

This decrease in calcium binding to casein is attributed to a decrease in hydrophobic binding sites of submicelles, which results in weakening of the extent of binding strength between submicelles (Kimura et al., 1992). The decrease in calcium mediated protein protein interactions also allows for increased hydration of the protein matrix, and hence a higher moisture cheese is produced and the serum expressed is also reduced (Joshi et al., 2004).

The $\mathrm{pH}$ of the curd also plays an important role in the distribution of the calcium between the soluble and insoluble states. At lower $\mathrm{pH}$, the calcium moves into the soluble phase and is subsequently released from the curd during syneresis. The solubilization of the colloidal calcium of the curd depends on the timing of acidification. Also, the amount and type of acid influence the solubilization of casein bound calcium (McMahon \& Oberg, 2011). Usually milk is pre-acidified to $\mathrm{pH}$ 6.2-6.4 prior to rennetting. Calcium losses are high when the $\mathrm{pH}$ drop is rapid before coagulation and cutting as in the case of directly acidified Mozzarella (before syneresis). Therefore, directly acidified mozzarella contains very low levels of calcium. The ratio of casein bound calcium to soluble calcium is a function of $\mathrm{pH}$, and it influences the characteristics of the curd during stretching process 
(Kindstedt et al., 2004). To attain a good texture, a curd with high calcium content should be plasticized at lower $\mathrm{pH}$, and low calcium content curd should be plasticized at a higher $\mathrm{pH}$. Curd made from demineralized skim milk produces good texture cheese if it is stretched at a higher $\mathrm{pH}$. Thus, plasticization and stretching can be achieved over an extraordinarily broad range of total curd calcium content (Kindstedt et al., 2004). Another factor playing an important role during stretching is the temperature. Kindstedt et al. (2004) suggested that a higher stretching temperature could contribute to a increased hydrophobically mediated aggregation, contraction of para-casein, and also calcium could shift to the casein-associated state, resulting in a more highly calcium cross linked, stronger, and more elastic fibers.

The conditions of low $\mathrm{pH}$ and high temperature contribute to limited aggregation of paracasein and form high tensile para-casein fibers (Taneya et al., 1992).

\section{H. Functional Properties of LMPS Mozzarella}

LMPS Mozzarella is mainly used as an ingredient in prepared foods; therefore, functional properties are essential features of this cheese (Kindstedt et al., 2004). The functional properties can be divided into properties before heating (shredding and firmness) and heat-induced properties (meltability, stretchability, oiling off, and browning). In this study, we concentrate on the properties before heating, and thereby they are discussed briefly below.

\section{Shreddability and Matting Behavior}

LMPS Mozzarella is manufactured in blocks, so shredding is needed before using it in pizzas or other foods to ensure uniform distribution and melting (Rankin et al., 2006). As 
explained by Kindstedt et al. 2004, the term shreddability refers to many functional properties such as:

1. The ability of block to be passed through the shredder easily

2. Geometry and integrity of the shreds

3. Property of the curd not to shatter and form fines during shredding

4. Ability of the cheese to be free flowing and not clump together after shredding. The problems with clogging the machines during shredding and causing the cheese to mat after shredding often occur when the cheese is soft and pasty. Firm and dry cheese cause the cheese to fracture easily and produce shattered shreds and fines (Childs et al., 2007).

Chen (2003) reported that mozzarella cheese to be shredded must be firm in texture and not adhesive. He reported that firmness does not vary over aging (a typical decrease is about one unit through three months of aging). He noted that adhesiveness changes to a greater extent with proteolysis. A firmer cheese with better shredding properties at higher moisture content of $50 \%$ can be obtained if the curd temperature after the stretching process was increased from $135^{\circ} \mathrm{F}$ to $150^{\circ} \mathrm{F}$. They did not observe this effect at $47 \%$ moisture. They also reported that without lowering the moisture content, firmer cheese could be obtained if the final $\mathrm{pH}$ of the cheese is higher, and the mineral (calcium) retention is increased.

Researchers found the firmer and less adhesive the cheese, the higher the quality of shreds. Commercial shredders use centrifugal force to direct cheese cubes into stationery blades, thus converting cheese cubes into shreds. A firm textured cheese has less deformation, and blades are able to make cleaner cuts. In addition, a firm textured cheese 
cube maintains a uniform speed, and blades can shred the entire length of the cube. On the other hand, a soft textured cheese bends and deforms around the blade, slowing the portion of the cheese cube in contact with the blade. The opposite side of cheese cube is moving faster and has greater momentum. The momentum directs the cube away from the blade before the blade cuts a full block length producing shorter and thinner shreds. An adhesive cheese sticks to the blades slowing the portion of the cheese in contact with the blade and resulting in shorter shreds (Rankin et al., 2006).

In low moisture Mozzarella, cheese composition, mainly high moisture content and fat content (FDM of 45\%), causes cheese to clog in the shredder. The increase in moisture content and fat in cheese causes a decrease in modulus of elasticity, which causes difficulty during shredding (Kindstedt et al., 2004).

Age of cheese at the time of shredding also affects the quality of shreds. Newly manufactured cheese has a lot of moisture on the surface than within the body of cheese and hence shreds poorly. Four to five days of ageing causes the moisture to absorb into the cheese due to hydration of the para-casein matrix, and thereby the shredding quality improves. Due to proteolysis, Mozzarella cheese that is aged too long will become too soft and gummy and thereby will clog in the shredder and will not produce high quality shreds (Kindstedt et al., 2004). 
Table 7. Factors influencing the shreddability of cheese (Adapted from Childs et al. 2007)

\begin{tabular}{lll}
\hline Factor & Effect & Shred-ability \\
\hline High moisture & Matting shreds & Decreases \\
$\begin{array}{l}\text { High Fat ( } \geq \text { fat\% in } \\
\text { DM) }\end{array}$ & Matting shreds & Decreases \\
$\begin{array}{l}\text { Too young } \\
\text { (Mozzarella day 1) }\end{array}$ & $\begin{array}{l}\text { Excessive free moisture at the } \\
\text { surface causes matting. }\end{array}$ & Decreases \\
$\begin{array}{l}\text { Too old ( 20 days } \\
\text { post manufacture) }\end{array}$ & $\begin{array}{l}\text { Ragged edges, fines, matting, } \\
\text { produces gummy balls }\end{array}$ & Decreases \\
Too firm, too dry & $\begin{array}{l}\text { Shatter into fines and small } \\
\text { particles }\end{array}$ & Decreases \\
\hline
\end{tabular}

Physical properties, such as firmness and adhesiveness, impact the behavior of the cheese during shredding. It is difficult to cleanly shred a hard cheese because it has a relatively low fracture strain. Also, it is challenging to evenly cut an over-acid cheddar cheese because it fractures and breaks at the edges (Guinee et al., 2002).

Aggregation index is an empirical test to measure clumping of properties and is based on the ability of the cheese to pass through a stack of sieves of decreasing mesh size without matting. Sticky cheese that mats a lot is retained by larger sieves whereas the cheese that does not clump together flows to the bottom of the stack relatively easily. The aggregation value (sum of (sieve size $\mathrm{x}$ mass retained by each sieve)) increased during storage and with higher fat content, indicating increased matting (Kindstedt et al., 2004). Banville et al. (2013) reported that aging did not significantly affect the adhesion of the cheese to the blade while shredding. However, they noticed an average of $18 \%$ difference 
in adhesion for cheese stored at eight and thirty-six days, indicating a trend that ageing increased adhesion. In addition, more adhesion was observed when the cheese was shredded at room temperature $\left(22^{0} \mathrm{C}\right)$ than at $4{ }^{0} \mathrm{C}$ and $13^{\circ} \mathrm{C}$. A lower rennetting $\mathrm{pH}$ was found to increase the adhesion on the blade when shredding is done at room temperature, causing the cheese to adhere more to the blade. However, lower rennetting $\mathrm{pH}$ decreased fines during the shredding process. They also observed that matting was highest in room temperature $22^{0} \mathrm{C}$ and lowest at $4^{0} \mathrm{C}$.

Childs et al. (2007) evaluated adhesive properties of cheese by measuring tack energy, which is the energy required to separate two materials that are not bound permanently. They concluded that an increase in tack energy was associated with an increase in cheese adherence to the cutting blade. Tack energy for Monterey jack and process cheese was greater than the tack energy for mozzarella cheese, which indicates that a three- month Monterey jack had greater adhesion to the blade than the young Mozzarella. They found that the tack energy and visco-elastic properties were the best indicators of shredding defects, and adherence to the blade was positively associated with cheese viscosity, and the production of fines was associated with increases in firmness.

\section{Texture of Cheese}

Fox et al. 2002 stated, "Rheology involves those properties that respond to stress or strain that is applied during processing and consumption of cheese." These properties include elasticity, viscosity, fracture stress, and firmness among others. Texture is defined as a sensory attribute resulting from the perceptions perceived by senses like sight, touch, chewing, and swallowing (Fox et al., 2000). 
Sensory evaluation of cheese texture requires extensive training, and therefore it is time consuming. Also, the wide variation in the test results can affect the conclusion of the study. As a result, instrumental methods were developed to quantify the sensory perceptions of texture (Fox et al., 2000).

Many empirical and imitative instrumental tests have been developed to measure the sensory texture descriptors, but by far the most popular imitative test is the uniaxial double bite compression test at a constant speed, using texture analyzers like Instron Universal testing Machine, TA.XT2 and TA.HD texture analyzers (Callagahan \& Guinee, 2004). The texture profile analysis (TPA) graph obtained using the double bite compression test is shown and explained in the material and methods section. Many studies have shown high correlation of mechanical parameters with sensory parameters like mechanical hardness with sensory hardness. Hence, by using instrumental methods, the small changes in physical characteristics of cheese can be quantified (Callagahan \& Guinee, 2004). However, because of factors like complexity of mastication, differences between individuals in the perception of texture, and the effect of time of day, the texture analyzer cannot become a complete substitute to sensory evaluation (Halmos, 2000).

The hardness or firmness of mozzarella studied using the similar uniaxial compression tests have shown that low moisture mozzarella became significantly softer with increasing age (proteolysis), higher levels of fat and moisture content, and decreasing levels of calcium and $\mathrm{pH}$ (Kindstedt et al., 2004).

Yun et al. (1993) reported that TPA hardness of un-melted low moisture mozzarella appeared to decrease with decreasing cooking temperature and increasing moisture 
content of the cheese. The TPA hardness and TPA springiness for all cheeses decreased with age. The TPA cohesiveness increased slightly during the first two weeks and then remained constant.

\section{Proteolysis and Ageing of Cheese}

A lot of researchers have shown that in low moisture mozzarella hardness and apparent viscosity decrease, and meltability, stretch-ability, and oiling off increase after the first few weeks of manufacture (Kindstedt et al., 2004). These functional changes are also due to the changes in structure of the cheese as a result of proteolysis, changes in serum phase, and an increase in the water binding capacity of the casein (Kindstedt et al., 2004, Kindstedt and Guo, 1997).

A brief ripening period of LMPS mozzarella (usually less than a month) is required for the cheese to get the desired functional properties (shredding and meltability) to be used as a pizza ingredient. Newly manufactured cheese has a lot of moisture at the surface and within the body of cheese, hence it will not shred well. Four to five days of ageing will allow the cheese to absorb the moisture back, and this will improve the shredding quality (McMahon \& Oberg, 2011). When cheese is maintained at cold temperatures for prolonged time of about two to three weeks, the cheese shreds better because the caseins become more hydrated and swollen (Figure 24) due to free water being absorbed back into the protein matrix (Kindstedt et al., 2004).

Several investigators have shown that the amount of serum, expressed from cultured low moisture mozzarella by centrifugation or pressing, decreased from levels of $20 \%-40 \%$ to no serum after two to three weeks of ageing (Kindstedt et al., 2004). Though, the serum decreases on ageing, the soluble calcium increases due to a decrease in hydrophobic 
interaction between the protein and calcium molecules. This allows more movement of the proteins in relation to each other, and hence the cheese melts easily when heated. As ageing continues, protein-protein interactions decreased because of the breakdown of protein through proteolysis, and thus the cheese melts too quickly and loses its stretch (McMahon \& Oberg, 2011).

Salt addition of $0.5 \%$ to $2.0 \%$ is known to increase the casein solubility (McMahon \& Oberg, 2011); therefore a $\mathrm{NaCl}$ - mediated redistribution of water at a microstructure level occurs during ageing (Kindstedt et al., 2004).

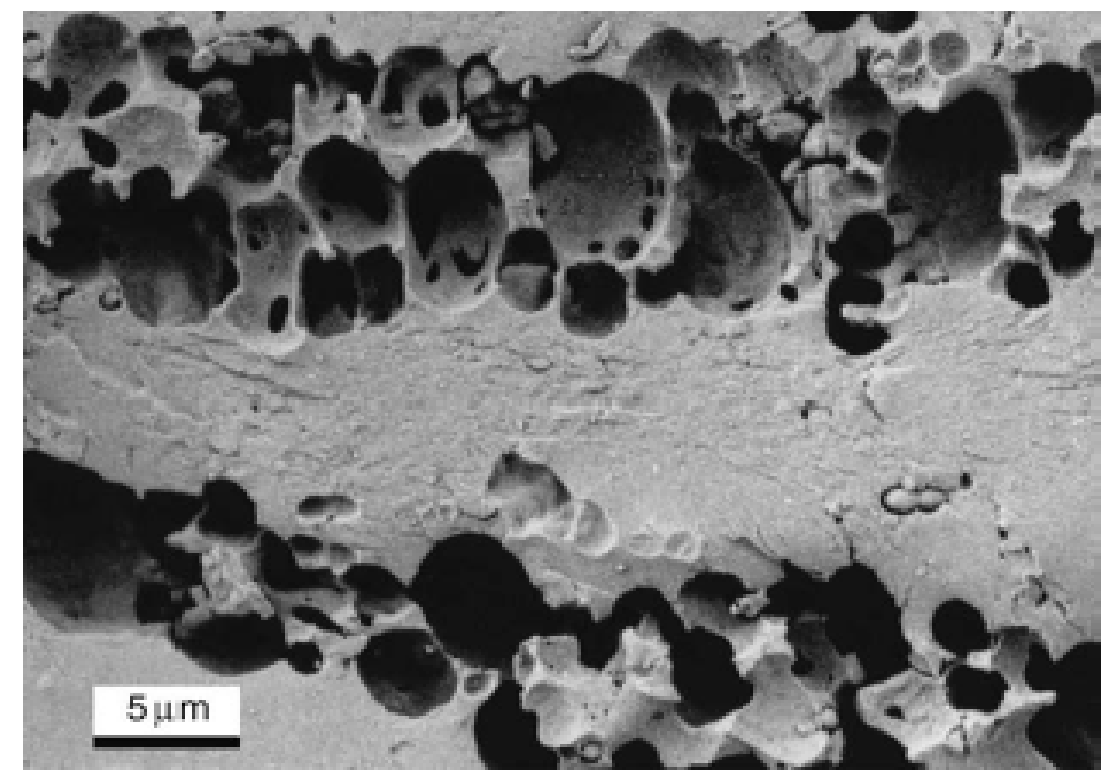

\section{Figure 24. Scanning electron micrograph of cheese after four weeks of storage (Taken from McMahon and Oberg, 2011).}

The initial breakdown of casein to larger peptides in low moisture mozzarella cheese occurs mainly through the action of the coagulant. The starter culture contributes to secondary proteolysis, which is degradation of the products of primary proteolysis to small peptides and amino acids (Kindstedt et al., 2004). Cheeses made with typical strains of St. thermophilus have very little proteolytic activity than cheeses made with St. 
thermophilus combined with Lactobacillus helveticus. This is because Lactobacillus helveticus has a more proteolytic activity whereas strains of St. thermophilus have very little proteolytic activity. Lactobacillus delbruekii also causes proteolysis of $\alpha_{\mathrm{s} 1}$-casein. The proteolysis of $\beta$-casein occurs very slowly with most of the $\beta$-casein remaining intact (McMahon \& Oberg, 2011). However, there is evidence of plasmin activity in mozzarella cheese during ripening, and this causes degradation of the $\beta$-casein to form the $\gamma$-casein (Creamer, 1976).

The proteolysis occurs in the first month of storage depending on cheese composition, residual coagulant, and manufacturing methods. Cheeses with higher moisture content undergo faster proteolysis. Increasing or decreasing the residual coagulant level in the cheese has a corresponding effect on the rate of initial cleavage of caseins. The extent of proteolysis varies widely depending on the temperature and time of hot water stretching and the consequent thermal inactivation of the starter culture. If the curd is stretched at a higher temperature, the residual coagulant and starter activity in the cheese will be limited; hence the cheese will have to be stored for a longer time to get the desirable functional properties (McMahon \& Oberg, 2011).

Feeney et al. (2001) reported that water-soluble nitrogen (WSN) soluble at $\mathrm{pH} 4.6$ increased in low moisture mozzarella as it matured at different temperatures for 70 days (Figure 25). After 15 days, there was significant difference in $\mathrm{pH} 4.6 \mathrm{WSN}$ between cheese ripened at $10^{0} \mathrm{C}, 15^{\circ} \mathrm{C}$, and cheese ripened at $0^{0}, 4^{0} \mathrm{C}$. Urea- PAGE of the $\mathrm{pH} 4.6$ insoluble portion showed that there was $\alpha_{\mathrm{s} 1}$-casein degradation during ripening and increasing temperatures affected the degradation significantly. The maximum proteolysis of $\alpha_{\mathrm{s} 1}$-casein was observed at $10^{\circ} \mathrm{C}$ and $15^{\circ} \mathrm{C}$. 


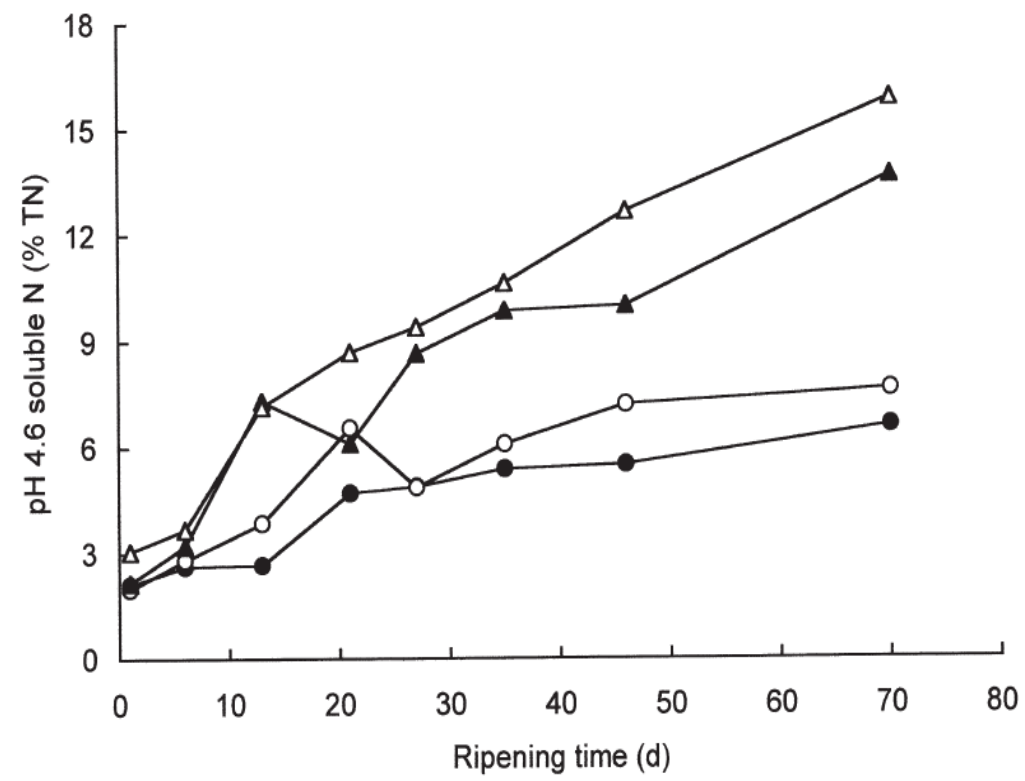

Low Moisture Mozzarella ripened at $0^{0} \mathrm{C}(0), 4^{0} \mathrm{C}(0), 10^{0} \mathrm{C}\left(\triangle \operatorname{and} 15^{0} \mathrm{C}(\mathrm{\Delta}\right.$

Figure 25. Level of pH4.6 soluble nitrogen expressed as a percentage of total nitrogen in low moisture mozzarella (Adapted from Feeney et al., 2001).

Yun et al. 1993 also demonstrated that higher cooking temperature resulted in a slower rate of proteolysis during storage. Soluble nitrogen contents increased with refrigerated storage time for all cheeses. The influence of refrigerated storage time was much greater than cooking temperature on proteolysis. The amount of $\alpha_{\mathrm{s}}$-casein as a percentage of total protein decreased significantly for all cheeses during refrigerated storage, and the rate of decrease was significantly affected by the differences in cooking temperature and with cheese age. The higher cooking temperature retarded the breakdown of $\alpha_{\mathrm{s}}$-caseins. There was not much breakdown of $\beta$-casein due to increased cooking temperature and during the refrigerated storage. 


\section{MATERIALS AND METHODS}

\section{A. Sample collection}

\section{Milk Sampling}

Composite milk samples were collected every week at a plant in Central Valley California from July 2008 to December 2009. A total of seventy-six milk samples were collected every week over a period of 18 months. A weekly composite milk sample was made from silo milk collected every day. One tablet of $18 \mathrm{mg}$ broad spectrum Microtabs II was added to the $40 \mathrm{ml}$ milk as a preservative, and the milk sample was stored at $4^{0} \mathrm{C}$. Two weekly composite milk samples were then shipped to Dairy Products Technology Center, California Polytechnic State University, San Luis Obispo, California (DPTC, Cal Poly) over night in a cooler box. The schematic diagram of the milk sampling plan is shown in Figure 26. 


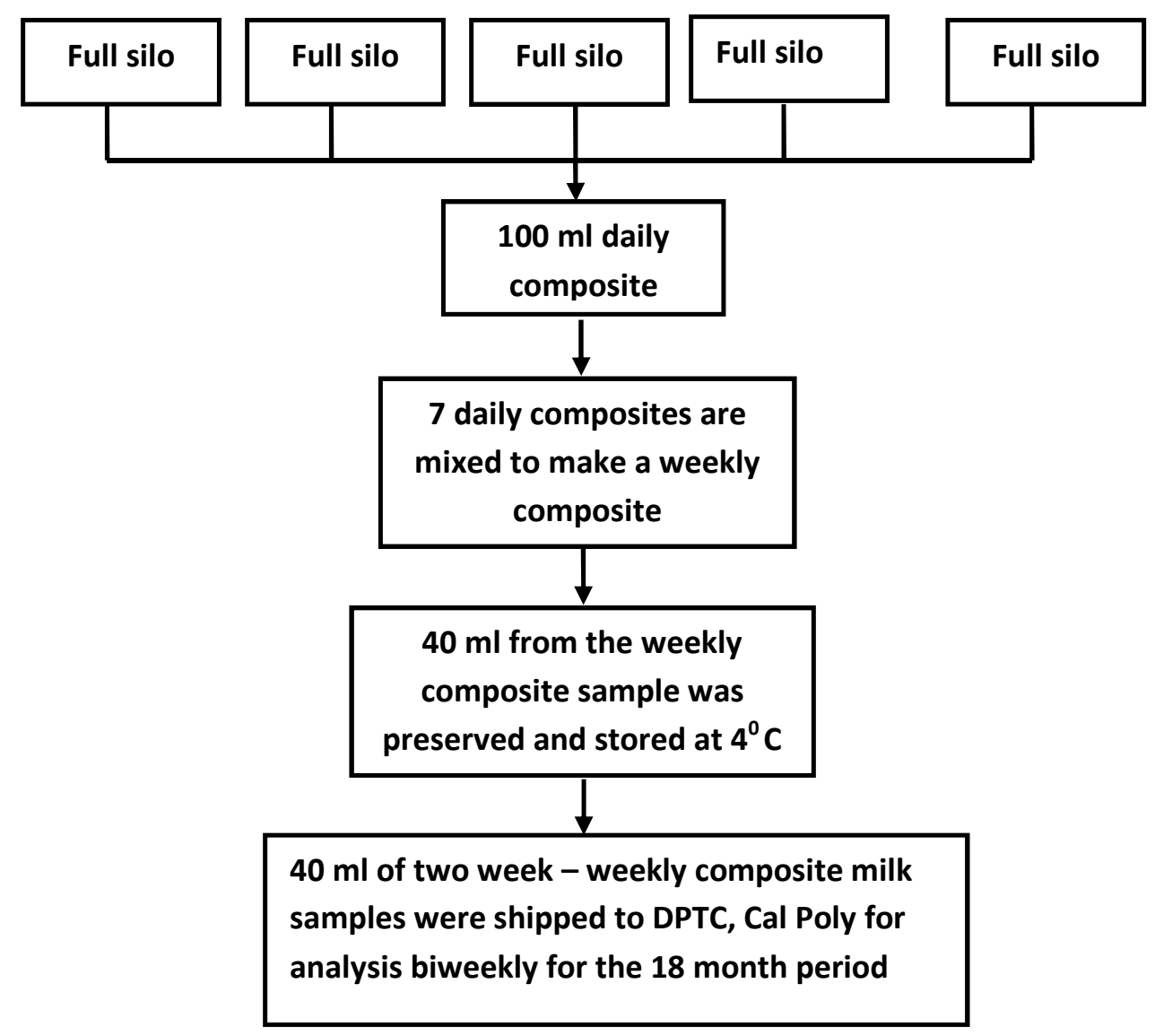

Figure 26. Milk sampling plan

\section{Low moisture part skim mozzarella (LMPS) sampling}

Cheese samples were collected from the same plant as that of the milk samples, but the samples were collected for a shorter period (July 2008 to mid-November 2009). A total of 33 cheese samples were collected biweekly whereas the milk samples were collected weekly. Three ten-pound blocks were sampled from the same vat/ batch of manufacture. The blocks were vacuumed packed and shipped to DPTC, Cal Poly, in a cooler box overnight. One block of cheese sample was analyzed exactly on the fifth day after the date of manufacture. The other two blocks were subjected to ripening for 21 days at different temperatures. The milk samples were a representation of the cheese milk used to make that week's cheese sample. As the milk was only a representation and not the exact 
milk from which the weekly cheese was made, the conclusions that can be drawn from this study are limited.

\section{B. Analysis of Milk Samples}

The milk samples received were stored at $4^{0} \mathrm{C}$. At the time of analysis the samples were heated to $38^{0} \mathrm{C}$ (Lacroix et al., 1996) and mixed well by swirling the sample cup for two minutes and subjected to the following analysis:

\section{Total Nitrogen}

The total nitrogen $(\mathrm{TN})$ content of milk samples was determined in duplicates by Kjeldhal method, and the results were expressed as a percentage protein. The percent total nitrogen $\mathrm{TN}(\%)$ was calculated using the below formula

$\frac{1.4007 \times(\text { Volume of } \mathrm{HCl} \text { in sample }- \text { Volume of } \mathrm{HCl} \text { in blank }) \times \text { Normality of NaOH}}{\text { Weight of Sample }}$

Total Nitrogen was converted to percent protein by multiplying by 6.38 . This method is from AOAC Official method 991.20, AOAC 2000

\section{Non-protein Nitrogen (NPN)}

NPN is urea and other non-protein compounds such as creatine, creatinine, uric acid, etc. Protein was precipitated by $15 \%$ trichloroacetic acid (TCA), and precipitated milk protein was removed by filtration. The filtrate contained the NPN and was used to determine non- protein nitrogen in duplicates by Kjeldhal method. Results were expressed as the percentage of non-protein nitrogen $(\% \mathrm{NPN})$ and calculated using the below formula

$$
\frac{1.4007 \times(V s-V b) \times M}{(W f \times W m) /(W-(W m \times 0.065))}
$$


Where,

$\mathrm{Vs}=\mathrm{ml}$ of $\mathrm{HCl}$ titrant used for test portion

$\mathrm{Vb}=\mathrm{ml}$ of $\mathrm{HCl}$ titrant used for blank

$\mathrm{M}=$ Molarity of $\mathrm{HCl}$ solution

$\mathrm{Wf}=$ Weight $(\mathrm{g})$ of $20 \mathrm{ml}$ filtrate

$\mathrm{Wm}=$ Weight $(\mathrm{g})$ of milk

$\mathrm{Wt}=\mathrm{Weight}(\mathrm{g})$ of milk plus $40 \mathrm{ml}$ of $15 \%$ TCA solution

This method is from AOAC Official method 991.21, AOAC 2000

\section{Non-casein Nitrogen (NCN)}

NCN was extracted from milk according to AOAC Official method 998.05, AOAC 1998.

Casein was precipitated from milk at $\mathrm{pH} 4.6$ using an acetic acid and sodium acetate solution. Precipitated milk casein was removed by filtration. The nitrogen content in the filtrate that contained the non-casein nitrogen components was determined by Kjeldhal in

duplicates. Results were expressed as the percentage of non-casein nitrogen (\% $\mathrm{NCN})$, which was calculated using the below formula

$$
\frac{1.4007 \times(V s-V b) \times M \times 2 \times \text { factor }}{W m}
$$

Where,

$\mathrm{Vs}=\mathrm{ml}$ of $\mathrm{HCl}$ titrant used for test portion

$\mathrm{Vb}=\mathrm{ml}$ of $\mathrm{HCl}$ titrant used for blank

$\mathrm{M}=$ Molarity of $\mathrm{HCl}$ solution

$\mathrm{Wm}=$ Weight $(\mathrm{g})$ of milk 
The factor is determined by the following formula

$$
\text { Factor }=1-\frac{(0.11 \times \text { fat } \%)}{100}+\frac{(0.07 \times \text { casein } \%)}{100}
$$

As the fat and casein content of milk was about $2.6 \%$ in calculation the factor was approximated to be 1.0. This method is from AOAC method 991.21, AOAC 2000

\section{True Nitrogen}

The true nitrogen ( $\mathrm{TrN} \%$ ) was calculated from subtracting non -protein nitrogen (NPN) from total nitrogen (TN - NPN) and true protein (\%) was obtained by multiplying TrN (\%) with 6.38 (Tremblay et al., 2003).

\section{Casein Nitrogen}

The casein nitrogen $(\mathrm{CN} \%)$ was calculated as the difference between total nitrogen and non-casein nitrogen $(\mathrm{TN}-\mathrm{NCN})$ and the casein protein $(\%)$ was obtained by multiplying CN (\%) with 6.38 (Tremblay et al., 2003).

\section{Total Solids}

Total solids were determined in duplicates by weighing milk (initial weight), drying milk, and weighing dried milk residue (final weight). 5 grams of the test samples were dried for approximately 4 hours at $100^{\circ} \mathrm{C} \pm 1^{0} \mathrm{C}$ in a forced air oven till a constant weight is reached between 5 minutes of drying. Total solids content of milk was the weight of dried milk residue and was expressed as a percentage of original milk weight. The percent moisture content was calculated using the below formula:

$$
\frac{(\text { Initial weight }- \text { Final weight }) \times 100}{\text { Initial weight }}
$$


And the percent total solid was calculated as $(100-\%$ Moisture content $)$. This method is from AOAC Official method 990.20, AOAC 2000

\section{Fat Content}

Fat was extracted using Mojonnier method where a mixture of ethers was used to extract fat from known weight of milk. Then the ether extract was decanted into dry weighing dish, and ether was evaporated. Extracted fat was dried to constant weight. Result was expressed as a percentage of fat by weight (AOAC Official method 989.05, AOAC 2000). The samples were analyzed in duplicates. The percent fat was calculated using the below formula:

$$
\frac{((\text { Weight of dish }+ \text { fat })-\text { Weight of dish }) \times 100}{\text { Weight of milk used for test }}
$$

\section{Somatic Cells}

Somatic cells were measured using a Delaval Somatic Cell Counter DCC. Milk sample was filled in a cassette and inserted in the Delaval Somatic Cell Counter DCC. The cassette has a DNA specific fluorescent reagent that stains the nuclei. Then a digital camera counts the stained nuclei while taking picture of the somatic cells' nuclei one by one. The readings were then displayed as the number of cells per micro liter of milk (Delaval cell counter DCC manual). The samples were run in triplicates.

\section{9. pH Measurement}

The $\mathrm{pH}$ of milk was measured in duplicates by using an Orion $\mathrm{pH}$ meter (model 410). Each time the $\mathrm{pH}$ meter was calibrated with buffers $\mathrm{pH} 4$ and $\mathrm{pH} 7$, and the slope was always $98 \%$ to $100 \%$. 


\section{Total Calcium}

Total calcium (\%) was measured in duplicates according to the method by Metzger et al. (2000a), followed by Varian 55B Atomic Absorption Spectrophotometer. A sample size of 0.75 gram of milk was added to 29.25 gram of $40 \%$ trichloroacetic acid. After 30 minutes, the mixture was filtered through Whatman Number 541. Ten grams of filtrate was added to 9.6 grams of distilled water and 0.4 gram of $5 \%$ lanthanum oxide. This final extract was then aspirated into Varian 55B Atomic Absorption Spectrophotometer fitted with a calcium lamp for calcium determination.

\section{Analysis of Cheese Parameters}

One block of $10 \mathrm{lb}$ cheese sample was analyzed on the fifth day after manufacture. If the cheese samples arrived early, the cheese was stored at $3.3^{0} \mathrm{C}$ before analysis. All the cheese samples were brought to a core temperature of $3.3^{0} \mathrm{C}$ before sampling for analysis. The analysis carried out on the cheese on a biweekly basis is described below.

\section{Total Nitrogen}

Total nitrogen (\%) was measured in duplicates according to AOAC official method 920.123, AOAC (2000). Two grams of cheese were taken and analyzed using Kjeldhal method, which follows the same procedure as the total protein determination of milk (see B. 1).

\section{Water Soluble Nitrogen (WSN)}

Water soluble nitrogen was extracted by homogenizing cheese with distilled water in the ratio of 1:2. The homogenized mixture was incubated at $40^{\circ} \mathrm{C}$ for one hour. Then the mixture was filtered using Whatman filter paper No. 1 (Kuchroo \& Fox, 1982). Five 
grams of the obtained filtrate were analyzed in duplicates for nitrogen content using Kjeldhal. The procedure followed in analysis of the filtrate was similar to that of total protein determination of milk (see B.1).

\section{3. pH Measurement}

The $\mathrm{pH}$ of cheese was measured in duplicates on 1:1 slurry of the cheese made with distilled water. The $\mathrm{pH}$ was measured using Orion $\mathrm{pH}$ meter model 410.

\section{Moisture Content}

The moisture content of cheese was measured in duplicates using vacuum oven method (AOAC Official Method 948.12, AOAC 2000). Two to three grams of cheese were weighed in a flat -bottomed metal dish, and the dish was weighed (initial weight was

noted). The dish was dried to constant weight in a vacuum oven at $100^{\circ} \mathrm{C}$. The dishes were removed and placed in a desiccator, cooled, and weighed (final weight). The percent moisture content was calculated using the below formula.

$$
\frac{(\text { Initial weight }- \text { Final weight }) \times 100}{\text { Initial weight }}
$$

\section{Fat}

The fat content of cheese was analyzed in duplicates using the Babcock method by Wehr \& Frank (2004). Ten $\mathrm{ml}$ of hot water were pipetted into a Babcock bottle containing 9.00 grams of cheese. The sample was thoroughly mixed and about $15 \mathrm{ml}$ of sulfuric acid was added in three $\mathrm{ml}$ aliquots in intervals. The bottle was mechanically shaken till the lump of cheese was broken down. Then, the bottle was filled with hot water and centrifuged to separate out the fat. The bottle was then incubated in a water bath at $60^{\circ} \mathrm{C}$, and the 
readings that marked read on the bottle corresponded to the percentage of fat in the cheese.

\section{Salt Content of Cheese}

The salt content of cheese was measured in duplicates using Nelson Jameson Chloride Analyzer M 925. Approximately five grams of the sample were measured and added to a blender jar. Taking into account the moisture of the cheese, distill water was added to yield a total of 100 grams.

Amount of water used $=100-($ Sample weight $\mathrm{x} \%$ Moisture in sample $)$.

The mixture was blended at a medium speed for 30 seconds. Then, the mixture was filtered using Whatman \#1 filter paper. The chloride analyzer was calibrated according to the owner's manual. Then, $250 \mu \mathrm{l}$ of the filtrate was added and titrated using the chloride analyzer, which provided the results in $\mathrm{mg} / \mathrm{l}$. The obtained reading was multiplied by 0.4 to get the percentage of salt in the cheese sample. Calibration of the machine and sample analysis was done according to Arnold (2008a) and the Nelson Jameson Chloride Analyzer M 925 manual

\section{Fat in Dry Matter (FDM)}

FDM (\%) was calculated using the formula

$$
\frac{\% \text { Fat of cheese }}{\% \text { Total solids in cheese }} \times 100
$$

\section{Total Calcium in Cheese}

Total calcium (\%) was measured in duplicates according to the method described by Metzger et al. (2000a). A sample size of 1.00 gram of cheese was blended with 30 gram 
of $40 \%$ trichloroacetic acid using a blender for 30 seconds. After 30 minutes, the mixture was filtered through Whatman Number 541. One gram of the obtained filtrate was added with nine grams of $40 \%$ trichloroacetic acid, 9.6 grams of distilled water, and 0.4 gram of 5\% lanthanum oxide. This final extract was then aspirated into Varian 55B Atomic Absorption Spectrophotometer fitted with a calcium lamp for calcium determination.

\section{Water Soluble Calcium in Cheese}

The water soluble calcium in cheese filtrate (\%) was measured in duplicates according to the method described in Metzger et al. (2000a) and Metzger et al. (2000b). Five grams of cheese were blended with 50 grams of distilled water at $60^{\circ} \mathrm{C}$ for 30 seconds using a blender. The cheese filtrate was then filtered through Whatman No. 1 filter paper (Metzger et al. 2000b). A final extract was prepared using the obtained filtrate as described by Metzger et al. (2000a) (except one gram of cheese filtrate was used to prepare the final extract instead of 0.75 gram of milk (see B.10)). The extract was then aspirated into Varian 55B Atomic Absorption Spectrophotometer fitted with a calcium lamp for calcium determination.

\section{Texture Attributes of LMPS Mozzarella}

\section{0. a. Textural Profile Analysis (TPA)}

Ten cubes of $2 \mathrm{~cm} \times 2 \mathrm{~cm} \times 2 \mathrm{~cm}$ were cut from different locations in a block of LMPS Mozzarella. Then, the cubes were covered and conditioned in the refrigerator for two hours followed by 30 minutes in room temperature. Five cubes were used to measure hardness, cohesiveness, springiness, and chewiness by using a TAX-T2 Texture Analyzer, Texture Technologies Corp., Scarsdale, NY. The cheese sample preparation and parameters were set in the TAX-T2 Texture Analyzer are according to procedure 
given by Arnold, 2008b. The analyzer is hooked up with a computer on which the following parameters are set up.

Table 8. Specific settings selected for TPA with the TA-XT2 texture analyzer.

\begin{tabular}{ll}
\hline Parameter Selected & Settings \\
\hline Test Mode & T.P.A \\
Pre Test Speed & $1.2 \mathrm{~mm} / \mathrm{s}$ \\
Post Test Speed & $1.2 \mathrm{~mm} / \mathrm{s}$ \\
Test Speed & $2 \mathrm{~mm} / \mathrm{s}$ \\
Distance & $10 \mathrm{~mm}$ \\
Compression & $50 \%$ \\
Time & $5 \mathrm{~s}$ \\
Force & $5 \mathrm{~g}$ \\
\hline
\end{tabular}

The computer generated Force vs. time profile is shown in Figure 27.

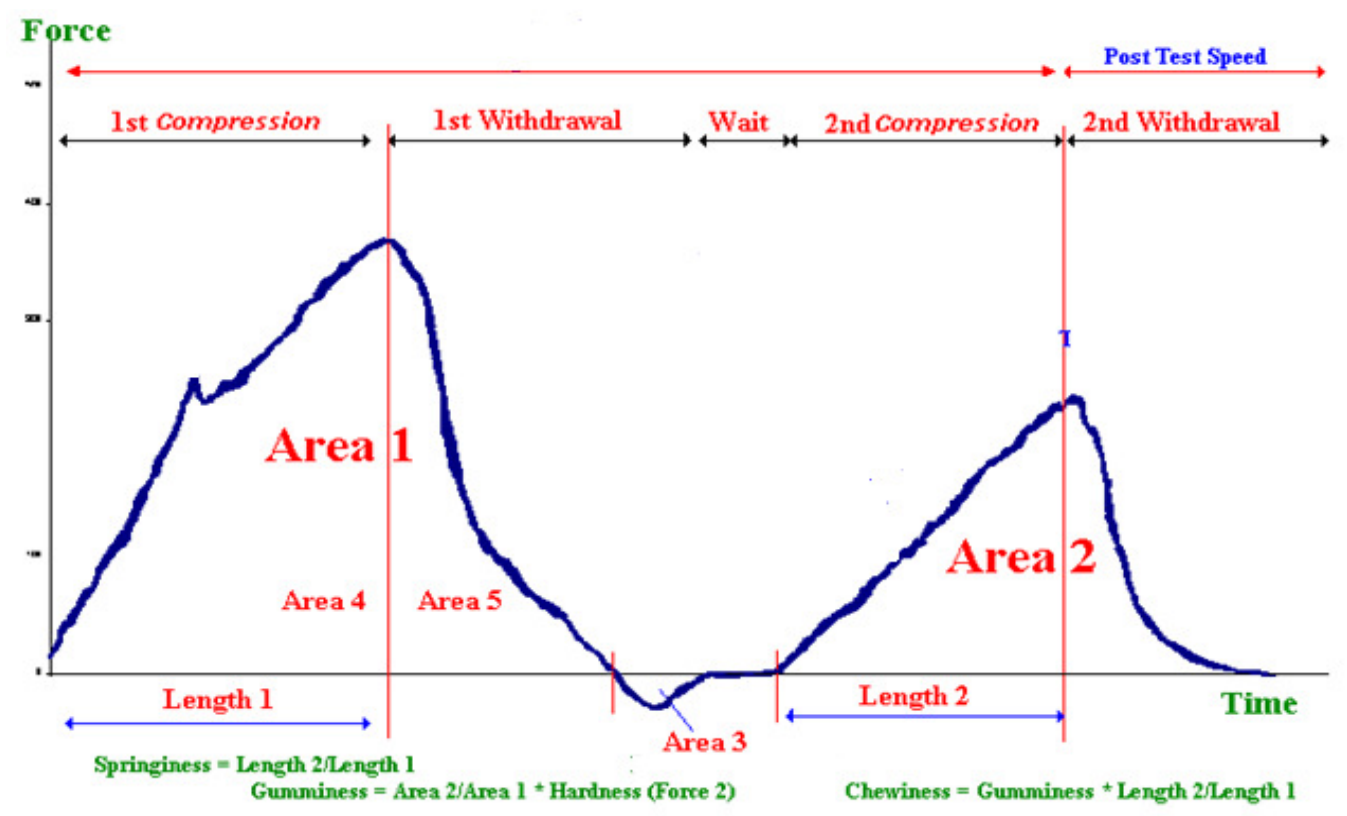

Figure 27. The texture profile analysis curve for cheese using TAX-T2 texture analyzer (Adapted from TTC Texture Technologies, 2009). 


\section{Definition of Texture Parameters and Physical Definitions}

\section{Hardness}

The force required to compress a cheese between the molar teeth or between the tongue and palate to a given deformation. The hardness was calculated as the peak force of the first compression of the product (peak of the first curve in Figure 27) (TTC Texture Technologies, 2009).

\section{Cohesiveness}

According TTC texture technologies website (2009) cohesiveness is "the extent to which a cheese can be deformed before it ruptures." Cohesiveness is basically how good the cheese withstands a second deformation relative to the first deformation. It was measured as the area of work during the second compression divided by the area of work during the first compression (Refer to Area 2/Area 1 in Figure 27) (TTC Texture Technologies, 2009).

\section{Springiness}

Springiness is defined as the extent to which the cheese physically springs back after it has been deformed. The cheese springs back to an extent after the first compression, so the wait time between the first and second compression can be relatively important. In some cases, a long wait time will allow a product to spring back more than it might under the conditions being researched.

Springiness was measured as the distance of the height of the cheese on the second compression (Length 2), divided by the original compression distance (Length 1) (Refer Length 1 and 2 in Figure 27) (TTC Texture Technologies, 2009). 


\section{Chewiness}

The length of time or the number of chews required to masticate a cheese ready for swallowing. Chewiness is a product of hardness, cohesiveness and springiness (TTC Texture Technologies, 2009).

\section{0. b. Aggregation Index (AGI)}

Aggregation index (AGI) is an empirical test to measure the matting behavior of cheese based on its ability to penetrate down through a stack of vibrating sieves of decreasing mesh size (Kindstedt et al., 2004). The procedure followed to measure AGI is adapted and modified version given in Kindstedt et al.,2004. A cheese sample of 500 grams was shredded from a block of cheese using Univex Shredder (Salem, NH). From the same block, another 500 grams of cheese was cut into $2 \mathrm{~cm} \mathrm{x} 2 \mathrm{~cm} \times 2 \mathrm{~cm}$ cubes. The temperature of cheese during the process was maintained at $3.3^{0} \mathrm{C} \pm 1^{0} \mathrm{C}$. Then, the cubes and shreds were placed in the top most sieve in a stack of sieves that had was arranged in a decreasing sieve size from top to bottom. The sieve sizes used were 6.35 $\mathrm{mm}, 5.6 \mathrm{~mm}, 4.74 \mathrm{~mm}, 3.35 \mathrm{~mm}, 2.36 \mathrm{~mm}, 1.00 \mathrm{~mm}$ and pan. The stack of sieves along with cheese was shaken in a mechanical shaker for 20 seconds. Sticky cheese that matted excessively was retained by larger sieves whereas cheese that remained free flowing penetrated to the bottom of the stack. Larger AGI indicated that the cheese matted excessively and vice versa (Kindstedt et al., 2004).

The aggregation index value of mozzarella cheese was calculated as a weighted average of sieve size $\mathrm{x}$ mass of cheese retained by each sieve divided by the total amount of cheese i.e., 


$$
\begin{gathered}
\mathrm{AGI}=\sum \frac{\text { Sieve size } \times \text { mass retained by each sieve after shaking }}{\text { total amount of cheese placed in the top most sieve before shaking }} \\
\text { 10. c. Percentage Loss during Shredding }
\end{gathered}
$$

A block of 2 pounds of cheese was shredded in a Univex Shredder (Salem, NH). The temperature of the cheese during shredding was maintained at $3.3^{0} \mathrm{C} \pm 1^{0} \mathrm{C}$. The percentage of cheese lost in shredder is calculated using the below formula.

$$
\frac{\text { Initial weight of cheese }- \text { Weight of cheese after shredding }}{\text { Initial weight of cheese }} \times 100
$$

\section{Statistical Analysis for Modeling the Seasonal Variation}

Seasonal variation of components in milk were analyzed using a multiple linear regression model equivalent to a basic single cosinor model $(\mathrm{Y}=\mathrm{m}+\mathrm{A} \cos (\mathrm{t}-\Phi)+\varepsilon)$ with sine and cosine of week as predictors

$$
y=\beta o+\beta 1 \text { cosine }(\text { time })+\beta 2 \text { sine }(\text { time })+\varepsilon
$$

Where y was the milk component and time was week between 1 and 52. Time was converted into an angular variable by multiplying it by $2 \pi / 52, \beta 0$ is the intercept, $\beta 1$ and $\beta 2$ are the slopes of the cosine and sine functions respectively, and $\varepsilon$ is the residual error term.

Peck \& Devore, 2008, stated the basic assumptions of the multiple linear regression model as follows:

1. "The distribution of $\varepsilon$ at any particular $\mathrm{x}$ value has a mean or average of zero.

2. The standard deviation of $\varepsilon$ is the same of any particular value of $\mathrm{x}$.

3. The distribution of $\varepsilon$ at any particular $\mathrm{x}$ value is normal. 
4. The random deviations $\varepsilon_{1}, \varepsilon_{2}, \varepsilon_{3} \ldots . . \varepsilon_{\mathrm{n}}$ associated with different observations are independent of one another".

Lacroix et al. (1996) used a second order periodic oscillatory Fourier model to analyze the seasonal variations in casein to total protein and casein to true protein ratios. The Fourier model is similar to the multiple linear regression model used in this study and is as follows:

$$
y=a o+\sum_{i=1}^{n=1} a i \cos (i \omega t)+b i \sin (i \omega t)
$$

Where $y$ was the response variable, $\mathrm{t}$ was the time (predictor), $\omega$ was the frequency and $\omega=360 / 12=30^{\circ}$, ai and bi were the regression coefficients, and ao was the intercept or the mean value for $y$.

Statistical analysis was done using Minitab version 17.0. The assumptions were checked using residual plots. To meet the model assumptions, the residuals were checked to have no systematic patterns.

\section{Interpretation of R-squared value in Multiple Linear Regression Model}

Coefficient of determination (R-squared value) is the statistical measurement that indicates how well the data fits the observed data. Frost (2013) defined R-squared value as the "percentage of the response variable variation that is explained by regression model."

$$
\mathrm{R} \text {-squared }=(\text { Explained variation }) /(\text { Total variation })
$$

Frost (2013) explained that R-square valued lies between zero and $100 \%$, where $0 \%$ and $100 \%$ means that the model explains no variability and all variability, respectively, of the 
response data around its average value. The higher the R-squared indicates that the model fits the data better.

\section{Interpretation of the p-value in Multiple Linear Regression Analysis}

The null hypothesis (Ho) in linear regression analysis is that the R-squared is equal to zero indicating that the model does not explain any variability in the response. The alternative hypothesis (Ha) is that the model explains at least some variability in the response. A p-value $<0.05$ indicates that the Ho can be rejected. This would show that the model explains some variability in the response (y value). The p-values for individual predictors can also be examined to test whether each predictor variable is significantly associated with the response, after controlling for all other predictors in the model. A pvalue $<0.05$ for such a test on an individual predictor indicates that it is a meaningful addition to the model because changes in the $\mathrm{x}$ value were associated with changes in the response variable (y). However, a p-value $>0.05$ indicates that the null hypothesis cannot be rejected and hence changes in the predictor were not related with changes in the response variable (Frost, 2013).

\section{E. Correlation Studies}

Correlation studies were carried out between milk components, cheese composition, cheese texture, and the milk composition and the corresponding week cheese composition and textural aspects using Minitab version 17.0. Correlations, except between milk composition and cheese composition and texture, were done for the 18-month period. The correlation analysis between milk composition and cheese composition, and texture was done only for a ten-month period because from May 2009 changes in the production 
protocol of cheese were done to increase the firmness of cheese, thereby reducing the loss during shredding. The $p$-values and Pearson correlation coefficient were noted.

\section{Interpretation of the Correlation or Pearson Correlation Coefficient}

The correlation coefficient measures the strength of a linear relationship between two variables. The correlation coefficient is always between -1 and +1 . The closer the correlation is to \pm 1 , the closer the two variables are to having a perfect linear relationship (Peck \& Devore, 2008). The correlation coefficient interpreted by Ratner, (http://www.dmstat1.com/res/ TheCorrelationCoefficientDefined.html) is as follows:

- 1.0 to -0.7 - strong negative association

- 0.7 to -0.3 - moderate negative association

-0.3 to +0.3 - little or no association

+0.3 to +0.7 - moderate positive association

+0.7 to +1.0 - strong positive association

\section{F. Ripening Studies}

Two blocks of $10 \mathrm{lb}$ vacuum packed cheese samples were subjected to ripening studies. One block was ripened at $3.3^{\circ} \mathrm{C}$ and the other at $8.9^{\circ} \mathrm{C}$ for 21 days from the date of manufacture. After 21 days, both the cheese blocks ripened at different temperatures were brought to a core temperature of $3.3^{0} \mathrm{C}$ before carrying out analysis.

The ripened samples were analyzed for $\mathrm{pH}$, WSN, and textural studies, which include Texture Profile Analysis (TPA), \% loss shredder, and aggregation index. 


\section{Statistical Analysis in Ripening Study}

The parameters of the cheese, ripened at different temperatures were compared using paired t-test analyzed using Minitab version 17.0. This test determines whether the parameters' means differ from each other in a significant way under the assumptions that the paired differences are independent and identically normally distributed. The data was analyzed using Minitab 17.0 and assumptions were checked using a normality plot. If the $\mathrm{p}$-value from the normality plot is greater than 0.05 , it means that the data may follow a normal distribution.

\section{Urea PAGE}

Proteolysis of the samples ripened at $3.3^{0} \mathrm{C}$ and $8.9^{\circ} \mathrm{C}$ was assessed by comparing with the fresh samples.

\section{2. a. Sample Preparation}

For ripening study, fresh cheese sample C08090110 (Jan 09) and 21 day cheese sample (same lot $\mathrm{C} 08090110$ ) ripened at $3.3^{0} \mathrm{C}$ and $8.9^{\circ} \mathrm{C}$ were taken and subjected to analysis. Sodium caseinate was used as reference standards for both the studies. The samples were prepared according to the procedure consolidated by Arnold, 2008c. A ten mg sample was mixed with $1.0 \mathrm{ml}$ of $1 \mathrm{X}$ sample buffer $(0.75 \mathrm{~g}$ tris base, $49 \mathrm{~g}$ urea, $0.4 \mathrm{ml}$ conc. $\mathrm{HCl}$, $0.7 \mathrm{ml}$ beta mercaptoethanol, $0.15 \mathrm{~g}$ bromophenol blue, and distilled water). For standard, five $\mathrm{mg}$ of sodium caseinate was mixed with $1.0 \mathrm{ml}$ of $1 \mathrm{X}$ sample buffer. The samples were incubated in a water bath for 30 minutes. 


\section{2. b. Gel Preparation}

$10 \%$ Poly acrylamide resolving gels were prepared by making a solution of $5.0 \mathrm{ml}$ of $40 \%$ poly acrylamide, $14.0 \mathrm{ml}$ of separating gel buffer (32.15 $\mathrm{g}$ of tris (hydroxymethyl) methylamine, $150 \mathrm{~g}$ urea, $2.86 \mathrm{ml}$ of concentrated $\mathrm{HCl}$ which is made up to $500 \mathrm{ml}$ with water (pH 8.9)), $10 \mu \mathrm{l}$ TEMED, $75.2 \mu \mathrm{l}$ of ammonium persulfate, $0.100 \mathrm{~g}$ of $\mathrm{N}, \mathrm{N}^{\prime}$ methylene bisacrylamide and $1.0 \mathrm{ml}$ of distilled water. The Bio-Rad Mini Protean gel spacer plates were assembled according to the manufacturer's instruction on the MiniPROTEAN 3 Multi-Casting Chamber. The prepared solution was then carefully pipetted in between the plates until they were 3/4th full. Then, distilled water was pipetted on top and the gel was allowed to polymerize for 30 minutes. Once the resolving gel was polymerized, the water layer was poured off, and the plates were filled with $4 \%$ acrylamide stacking gel solution $(9.0 \mathrm{ml}$ of stacking buffer $(4.15 \mathrm{~g}$ of tris

(hydroxymethyl) methylamine, $150 \mathrm{~g}$ urea, $2.2 \mathrm{ml}$ of concentrated $\mathrm{HCl}$ which is made up to $500 \mathrm{ml}$ with water), $10 \mu 1$ TEMED, $60 \mu \mathrm{l}$ of ammonium persulfate, $\mathrm{pH} 7.6), 0.1 \mathrm{ml}$ of SDS ml, $1 \mathrm{ml}$ of $40 \%$ acrylamide, 50 micro L of $10 \%$ APS, 5 micro L of TEMED). A Mini Protean Comb was inserted to generate the wells and was allowed to polymerize for 15 minutes. The gel was prepared according to the procedure consolidated by Matt R. Arnold, 2008c.

\section{2.c. Running Gel}

The above prepared gel plates were removed from Mini-PROTEAN 3 Multi-Casting Chamber and were mounted in XCell Surelock ${ }^{\mathrm{TM}}$ Mini-Cell chamber (EI0001). The chamber was then filled with electrode buffer ( $3.0 \mathrm{~g}$ tris base, $14.6 \mathrm{~g}$ glycine, and 1000 $\mathrm{ml}$ of distilled water, $\mathrm{pH}$ 8.4). The cell unit was connected to a Bio-Rad power unit (PAC300, BioRad) and was pre run for 15 minutes at $150 \mathrm{~V}$. Then, the gel was loaded 
with $4 \mu \mathrm{l}$ of the samples and standards. The gel was run at $100 \mathrm{~V}$ for 90 minutes or until the tracking buffer line reached the end of the plate. The gel was removed from the cell unit and spacer plates. The gel was immersed in a staining solution ( $2.5 \mathrm{~g}$ Coomassie Brilliant Blue R -250) and incubated in this solution overnight on a rotary incubator (Max 2000 E-class, Barnstead, IA) at room temperature. After 24 hours the gels were removed from staining solution and de-stained with several changes of distilled water. The gel was prepared according to the procedure consolidated by Arnold, 2008c. 


\section{RESULTS AND DISCUSSION}

The results are summarized in parts and are briefly discussed below. In the first part of the study, the seasonal variation and correlation between milk components in weekly bulk milk samples (76 samples) collected from a plant in Central Valley, California were studied for an 18- month period. Secondly, the thirty-three low moisture part skim mozzarella samples collected on a biweekly basis from the same plant during the same period was analyzed for any variation in their composition and un-melted textural properties (shreddability, aggregation index, \% loss in shredder, and TPA characteristics). Correlation analyses were done among the cheese composition, cheese textural characteristics', and between cheese composition and texture. In the third part, the association between milk composition and cheese composition and texture were studied using correlation analysis. Finally, the association between ripening temperature and the cheese $\mathrm{pH}$, water soluble nitrogen, and un-melted textural properties of LMPS Mozzarella was studied.

This was an observational study, and hence no cause and effect conclusions can be drawn as there are a lot of variables that were not controlled.

\section{A. Analysis of Milk}

\section{Milk Composition}

The average data for milk composition for seventy-six bulk milk samples obtained from silos on a weekly basis from a plant in Central Valley, California from July 2008 to December 2009 are shown in Table 9. 
Table 9. Descriptive statistics for milk composition:

\begin{tabular}{lccccc}
\hline & Sample & & & & \\
Milk components & size & Mean & SD & Min. & Max. \\
\hline Total protein $(\%)$ & 76 & 3.29 & 0.115 & 3.04 & 3.48 \\
Total nitrogen $(\mathrm{TN})(\%)$ & 76 & 0.52 & 0.173 & 0.48 & 0.55 \\
True protein $(\%)$ & 76 & 3.13 & 0.093 & 2.89 & 3.31 \\
True nitrogen $(\%)$ & 76 & 0.49 & 0.015 & 0.45 & 0.52 \\
Non-Protein Nitrogen & 76 & 0.025 & 0.0042 & 0.016 & 0.035 \\
(NPN) $(\%)$ & & & & & \\
Non-Casein Nitrogen & 76 & 0.11 & 0.008 & 0.089 & 0.128 \\
(NCN) $(\%)$ & & & & & \\
Casein nitrogen $(\%)$ & 76 & 0.41 & 0.021 & 0.36 & 0.44 \\
Casein nitrogen $(\mathrm{CN})(\%)$ & 76 & 2.63 & 0.134 & 2.32 & 2.85 \\
Casein/ total protein $(\mathrm{CP})$ & 76 & 0.799 & 0.018 & 0.76 & 0.829 \\
Casein/true protein $(\mathrm{CPt})$ & 76 & 0.84 & 0.02 & 0.79 & 0.881 \\
Fat $(\%)$ & 74 & 2.56 & 0.65 & 1.15 & 3.87 \\
Total solids $(\%)$ & 75 & 11.54 & 0.680 & 9.65 & 12.87 \\
Total calcium $(\%)$ & 76 & 0.11 & 0.0058 & 0.09 & 0.12 \\
pH & 76 & 6.66 & 0.039 & 6.53 & 6.71 \\
Somatic cells / $\mu \mathrm{L}$ & 76 & 262.61 & 79.22 & 122.00 & 508.67 \\
\hline
\end{tabular}

The mean \pm standard deviations of total protein and true protein for the bulk milk samples were $3.29 \% \pm 0.12 \%$ and $3.13 \% \pm 0.09 \%$, respectively (Table 9). The total protein of milk was close to the mean total protein values reported by Nickerson (1960), Bruhn and Franke (1987), and Franke et al. (1987) in California milk. Other researchers reported a range of total protein content of $3.32 \%$ to $3.02 \%$ for milk produced by Holstein cows (Bruhn \& Franke, 1977). The range $3.04 \%$ to $3.48 \%$ for total protein of milk in this survey falls close to that of milk produced from Holstein cows.

The mean values of non-protein content and non-casein nitrogen, $0.025 \%$ and $0.1056 \%$, respectively (Table 9), were similar to the values reported by Lacroix et al. (1996) in Quebec milk. However, Nickerson (1960) reported a NPN with a mean \pm standard deviation of $0.0314 \% \pm 0.0016 \%$ in California milk, which was higher than what was observed in this study. 
The casein fraction represented $79.91 \% \pm 1.7 \%$ of the total protein $(\mathrm{CP})$ and $83.97 \% \pm$ $2.14 \%$ of true protein $(\mathrm{CPt})$ (Table 9), which was in range with the values (CP $78.92 \%$ ) and CPt (83.12\%) reported by Lacroix et al. (1996) in Quebec milk samples. However, the mean $\mathrm{CP}$ value of $79.91 \%$ is higher than the mean value of $76.71 \%$ and $76.4 \%$ reported by Nickerson (1960) and Franke et al. (1987), respectively, in milk from California. The larger range of standard deviation observed for CPt compared with CP indicates that casein varied more to true protein than that of total protein. This larger variation of casein may due to variation of NPN along with TN. As standardization of milk is done with a target of casein to fat ratio, hence a variation of casein or fat in milk will affect the hardness of cheese unless the moisture content of the curd is increased or decreased to accommodate the changes in hardness (Gunasekaran and Ak, 2000a). In this study, the average \pm standard deviation of fat content in bulk milk samples was found to be $2.56 \% \pm 0.66 \%$ (Table 9 ). The mean value of fat content was low compared to mean values observed $3.82 \%$ and $3.67 \%$ by Nickerson (1960) and Bruhn \& Franke (1991), respectively, in California milk. The minimum was found to be as low as $1.15 \%$ and high as $3.87 \%$ (Table 9). The milk samples were heated to $38^{0} \mathrm{C}$ before analysis to allow fat to get distributed evenly. However, the variation of milk fat was very high with a $\pm 0.66 \%$ standard deviation during the entire sampling period.

The average value for total solids was $11.543 \%$ with a standard deviation of $\pm 0.680 \%$ (Table 9), which was close to $11.18 \% \pm 1.432 \%$ reported by Ozrenk \&Inci (2008). Some researchers reported the average total solids content of milk as $12.5 \%$ (Walstra et $a l ., 2006)$. The total solids like any other milk components were found to vary according 
to breed and other factors (Nickerson, 1960 and Ozrenk \&Inci, 2008). The standard deviation of total solids was $\pm 0.68 \%$ (Table 9), which was close to that of fat $\pm 0.66 \%$. The mean \pm standard deviation of total calcium in silo milk samples was found to be $0.11 \% \pm 0.006 \%$ (Table 9), which was quite in range with the values reported by Metzger et al. (2000a) (0.114\%) and Fox and Cogan (0.12\%). Calcium plays an important role in rennet coagulation and firmness of milk coagulum during the cheese making process. Also in mozzarella, the inherent casein associated calcium and phosphate influences the ability of curd to plasticize and form unidirectional fibrous structure (Kindstedt et al., 1999).

The average somatic cell count (SCC) along with the standard deviation in the bulk milk samples for the 18 month period was $262.61 \pm 79.22$ cells $/ \mu 1$, which was within the range for healthy cows $(\mathrm{SCC}<750,000$ cells/ml). Barbano et al. (1987) reported that the milk from sub clinical mastitis has $\mathrm{SCC} \geq 500,000$ cells $/ \mathrm{ml}$ and this could affect the quality of milk, in turn affecting the yield and quality of cheese. The maximum value during the study obtained was 508, 000 cells/ml. This somatic cell count greater than 500,000 cells/ml was found only for two samples (May 2009 and October 2008 - Appendix 1). Other than the two milk samples, most of the milk samples had somatic cell count below 500,000 cells $/ \mathrm{ml}$, which indicates that all the milk samples were free from mastitis. The average \pm standard deviation of $\mathrm{pH}$ for the milk samples was found to be $6.66 \pm$ 0.039, which is within the normal range of 6.7 (Kelly, 2000a). 


\section{Correlation of Milk Composition}

The data of milk components collected from weekly milk samples for 18 months was subjected to correlation analysis in Minitab version 17.0 to see if the variation of the components had an association with each other. The results are summarized in Table 10.

Table 10. Correlation between milk components

\begin{tabular}{|c|c|c|c|c|c|c|c|c|c|c|}
\hline & TN & $\operatorname{Tr} N$ & NPN & $\mathbf{N C N}$ & $\mathrm{CN}$ & $\overline{C P}$ & $\mathrm{CPt}$ & Fat & TS & $\begin{array}{c}\text { Total } \\
\text { Ca }\end{array}$ \\
\hline $\operatorname{Tr} \mathbf{N}$ & $\begin{array}{l}0.975 \\
0.000\end{array}$ & & & & & & & & & \\
\hline NPN & $\begin{array}{l}0.601 \\
0.000\end{array}$ & $\begin{array}{l}0.408 \\
0.000\end{array}$ & & & & & & & & \\
\hline NCN & $\begin{array}{l}0.081 \\
0.486\end{array}$ & $\begin{array}{l}0.025 \\
0.830\end{array}$ & $\begin{array}{l}0.243 \\
0.034\end{array}$ & & & & & & & \\
\hline $\mathbf{C N}$ & $\begin{array}{l}0.945 \\
0.000\end{array}$ & $\begin{array}{l}0.920 \\
0.000\end{array}$ & $\begin{array}{l}0.573 \\
0.000\end{array}$ & $\begin{array}{c}-0.181 \\
0.118\end{array}$ & & & & & & \\
\hline CP & $\begin{array}{l}0.652 \\
0.000\end{array}$ & $\begin{array}{l}0.635 \\
0.000\end{array}$ & $\begin{array}{l}0.393 \\
0.000\end{array}$ & $\begin{array}{r}-0.547 \\
0.000\end{array}$ & $\begin{array}{l}0.864 \\
0.000\end{array}$ & & & & & \\
\hline CPt & $\begin{array}{l}0.703 \\
0.000\end{array}$ & $\begin{array}{l}0.626 \\
0.000\end{array}$ & $\begin{array}{l}0.638 \\
0.000\end{array}$ & $\begin{array}{c}-0.399 \\
0.000\end{array}$ & $\begin{array}{l}0.882 \\
0.000\end{array}$ & $\begin{array}{l}0.958 \\
0.000\end{array}$ & & & & \\
\hline Fat & $\begin{array}{r}-0.175 \\
0.134\end{array}$ & $\begin{array}{r}-0.162 \\
0.164\end{array}$ & $\begin{array}{c}-0.134 \\
0.253\end{array}$ & $\begin{array}{c}-0.132 \\
0.258\end{array}$ & $\begin{array}{c}-0.126 \\
0.283\end{array}$ & $\begin{array}{c}-0.022 \\
0.848\end{array}$ & $\begin{array}{c}-0.052 \\
0.655\end{array}$ & & & \\
\hline TS & $\begin{array}{r}-0.021 \\
0.858\end{array}$ & $\begin{array}{r}-0.023 \\
0.847\end{array}$ & $\begin{array}{r}-0.005 \\
0.967\end{array}$ & $\begin{array}{r}-0.140 \\
0.232\end{array}$ & $\begin{array}{l}0.047 \\
0.689\end{array}$ & $\begin{array}{l}0.139 \\
0.236\end{array}$ & $\begin{array}{l}0.121 \\
0.303\end{array}$ & $\begin{array}{l}0.932 \\
0.000\end{array}$ & & \\
\hline $\begin{array}{l}\text { Total } \\
\text { Ca }\end{array}$ & $\begin{array}{l}0.502 \\
0.000\end{array}$ & $\begin{array}{l}0.462 \\
0.000\end{array}$ & $\begin{array}{l}0.404 \\
0.007\end{array}$ & $\begin{array}{l}0.119 \\
0.325\end{array}$ & $\begin{array}{l}0.487 \\
0.000\end{array}$ & $\begin{array}{l}0.351 \\
0.003\end{array}$ & $\begin{array}{l}0.407 \\
0.000\end{array}$ & $\begin{array}{c}-0.114 \\
0.350\end{array}$ & $\begin{array}{r}-0.035 \\
0.776\end{array}$ & \\
\hline pH & $\begin{array}{c}-0.060 \\
0.609\end{array}$ & $\begin{array}{c}-0.078 \\
0.500\end{array}$ & $\begin{array}{l}0.037 \\
0.751\end{array}$ & $\begin{array}{l}0.202 \\
0.081\end{array}$ & $\begin{array}{r}-0.099 \\
0.397\end{array}$ & $\begin{array}{c}-0.141 \\
0.225\end{array}$ & $\begin{array}{c}-0.106 \\
0.360\end{array}$ & $\begin{array}{l}0.041 \\
0.728\end{array}$ & $\begin{array}{r}-0.002 \\
0.985\end{array}$ & $\begin{array}{c}-0.105 \\
0.389\end{array}$ \\
\hline $\begin{array}{l}\mathrm{SCC} / \\
\mu \mathrm{L}\end{array}$ & $\begin{array}{l}0.010 \\
0.934\end{array}$ & $\begin{array}{c}-0.007 \\
0.950\end{array}$ & $\begin{array}{l}0.065 \\
0.574\end{array}$ & $\begin{array}{c}-0.156 \\
0.179\end{array}$ & $\begin{array}{l}0.064 \\
0.583\end{array}$ & $\begin{array}{l}0.136 \\
0.241\end{array}$ & $\begin{array}{l}0.138 \\
0.233\end{array}$ & $\begin{array}{l}0.047 \\
0.687\end{array}$ & $\begin{array}{l}0.110 \\
0.347\end{array}$ & $\begin{array}{l}0.017 \\
0.892\end{array}$ \\
\hline
\end{tabular}

Cell content: Pearson correlation coefficient on top and p-value on the bottom. The yellow markings indicate significant correlation at the $5 \%$ significance level.

The total nitrogen $(\mathrm{TN})$, non-protein nitrogen $(\mathrm{NPN})$, casein nitrogen $(\mathrm{CN})$, casein to total protein ratio $(\mathrm{CP})$, casein to true protein ratio $(\mathrm{CPt})$, and total calcium had positive correlation $(\mathrm{r}>0.3$ and $p$-value $<0.05)$ with each other (Table 10). However, the noncasein nitrogen $(\mathrm{NCN})$ did not significantly correlate with other nitrogen fractions and total calcium (Table 10). The total solids had a strong positive correlation $(\mathrm{r}>0.7, p$ - 
value $<0.05$ ) only with the fat and not with the other components (Table 10, Figure 28). Hence the variation of total solids followed similar pattern. Also, any error in analysis of fat can be ruled out because the variation was also seen in total solids.

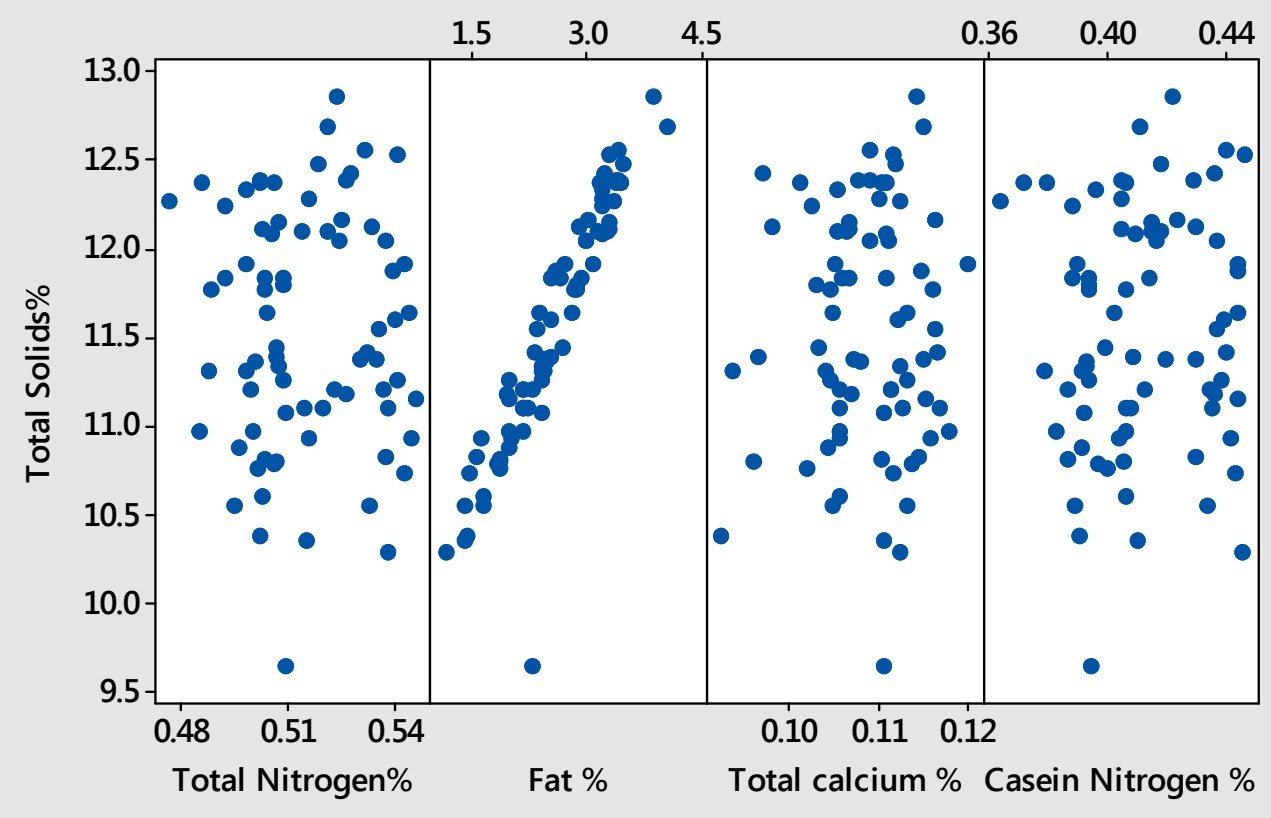

Figure 28. Variation of total solids with respect to total nitrogen, fat, total calcium and casein nitrogen.

\section{Variation of Milk Composition}

All the milk components (total protein, true protein, casein, casein/total protein, casein/true protein, fat, total solids, total calcium, $\mathrm{pH}$, and somatic cells) were plotted versus time (July 2008 to December 2009) to see if there was any variation over the 18 months for the seventy-six samples. The curves in the graphs (Figure 29, Figure 30, Figure 31, and Figure 32) just trace the trend and are not the fitted curve of the linear regression model used in analysis. 


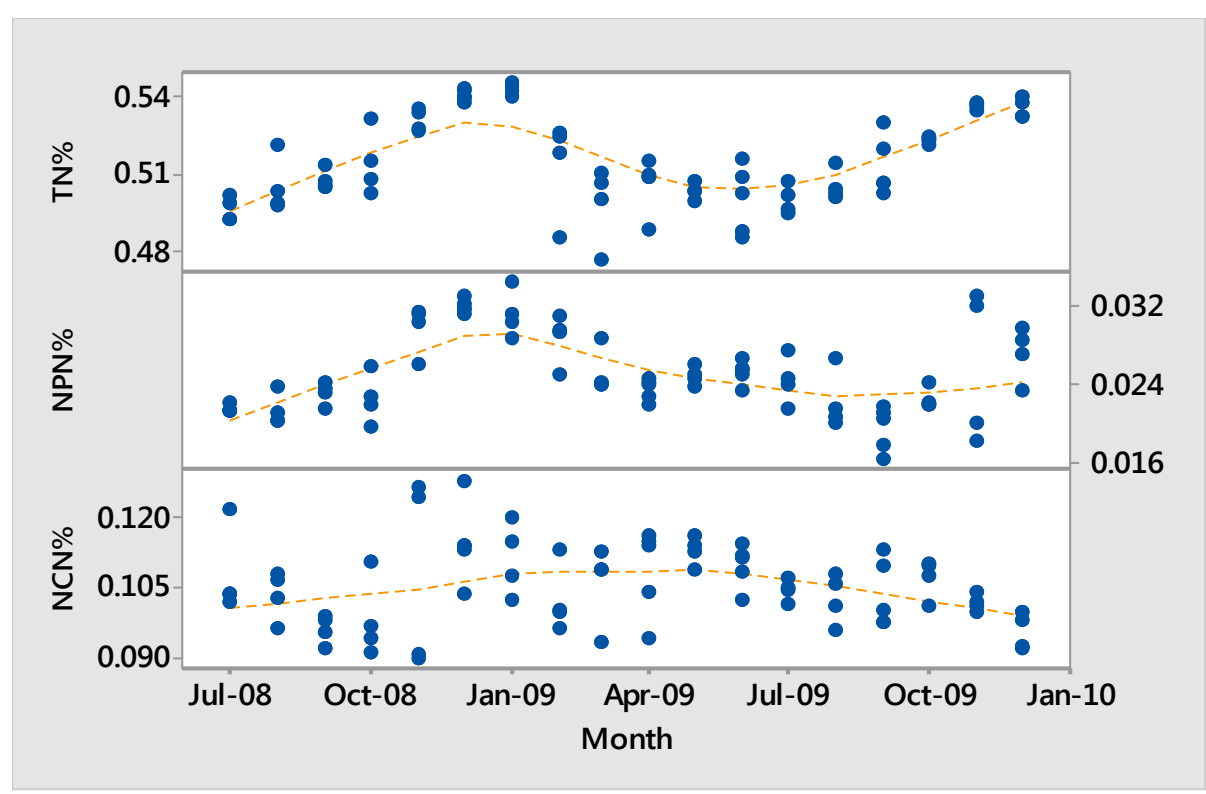

Figure 29. Variation of Nitrogen fractions (total nitrogen (TN), non-protein nitrogen (NPN), and non-casein nitrogen (NCN)) in milk

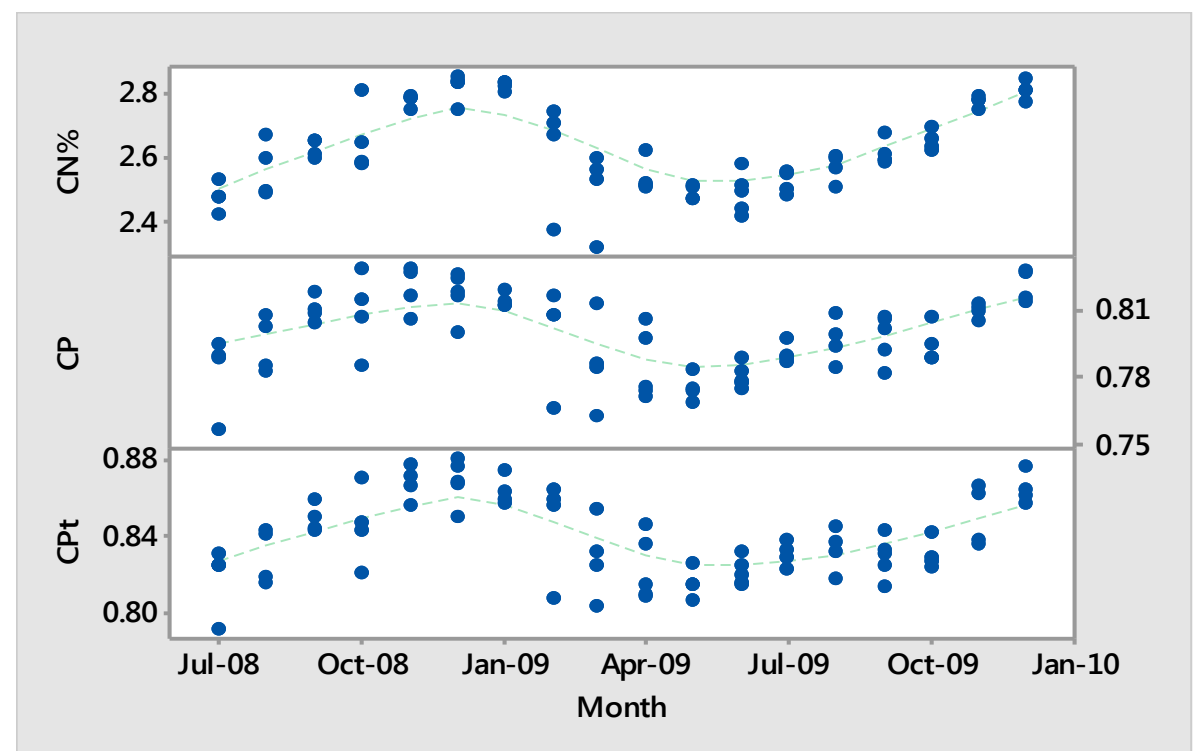

Figure 30. Variation of casein, casein/total protein ratio, and casein/true protein ratio 


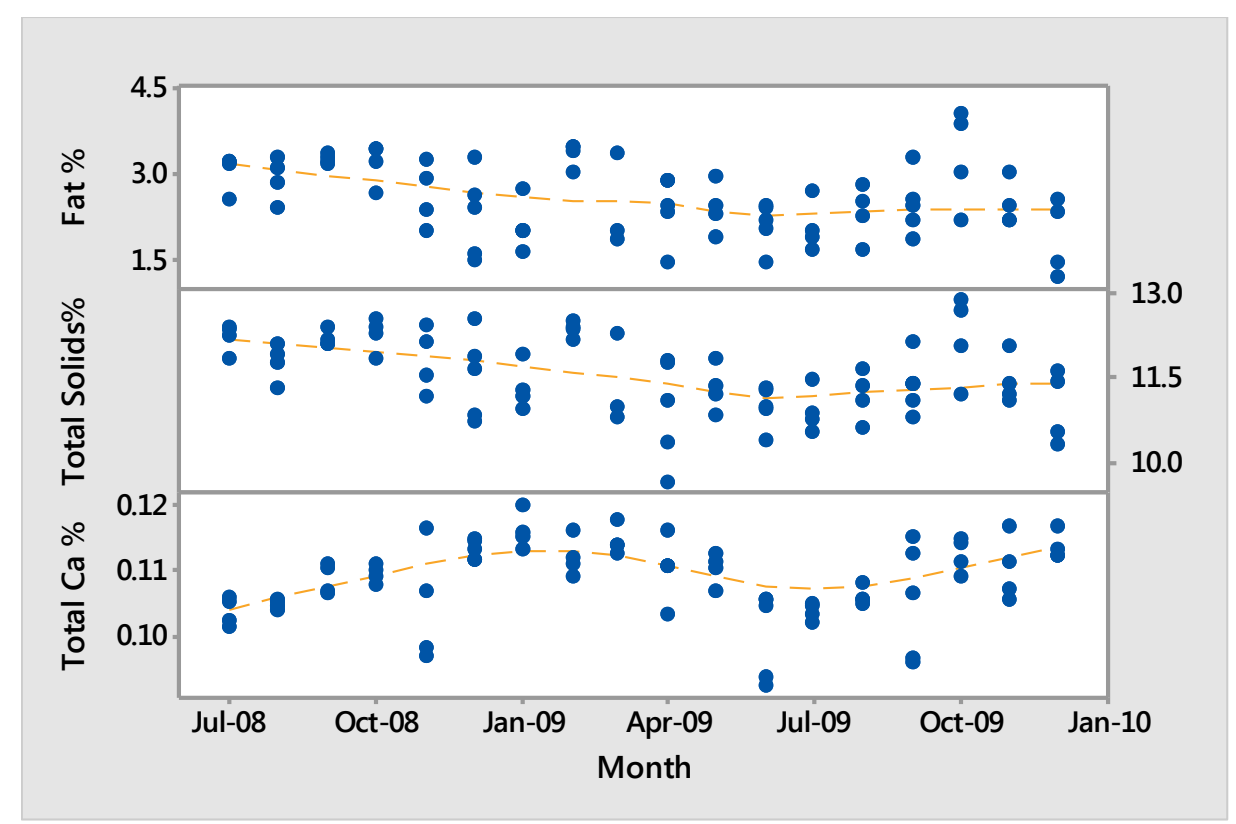

Figure 31. Variation of fat, total solids, and total calcium in milk

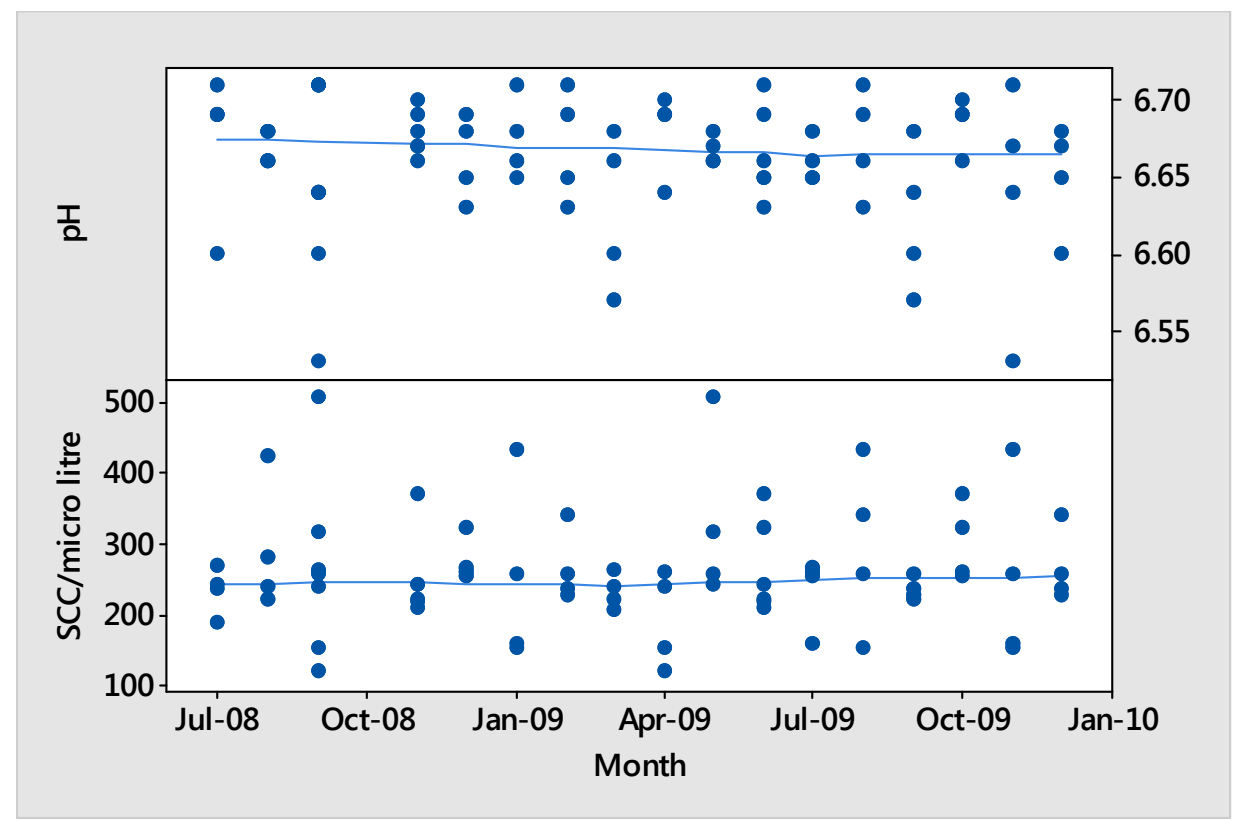

Figure 32. Variation of pH and somatic cell count

From Figure 29, Figure 30, and Figure 31, a cyclic pattern was observed for total nitrogen, non-protein nitrogen, casein, casein to total protein ratio (CP), casein to true 
protein ratio $(\mathrm{CPt})$, and total calcium. Higher total nitrogen was observed during winter months (November - February) (Figure 29) and lowest ones during summer (May August). Bernabucci et al. (2002), Ozrenk \&Inci (2008), Bertocchi et al. (2013), Verdi et al. (1987), and Lacroix et al. (1996) found similar variation of total nitrogen in different parts of world. In California, Nickerson (1960), Bruhn \& Franke (1991), and Bruhn \& Franke (1977) observed that the fat and protein content were significantly lower from May through August and higher from November through February. However, Frank et al. (1987) reported that they did not observe any seasonal variation of total protein in California milk in 1983.

The non-protein nitrogen (NPN) was found to be high during winter (October 2008 February 2009) (Figure 29) and lowest values were observed during summer (May August). Similar seasonal variation of NPN was observed by Nickerson (1960) and Verdi et al. (1987). On the contrary, Lacroix et al. (1991) observed a different trend; the NPN remained constant from January to April then increased until September and decreased thereafter. In the later part of this study, from October 2009 to December 2009, there was no increase of NPN and it remained relatively constant (Figure 29). Laben (1963) mentioned in his review that in a three-year study in California solid not fat varied for two years $(1960,1962)$, but in 1961 no seasonal variation was observed. A similar variation (higher for one winter and no increase for the next year) was observed for NPN. Hence, an extended study would have given more information on this variation. The non-casein nitrogen variation did not show any particular pattern in the scatter plot (Figure 29). In contrast to this observation, Lacroix et al. (1991) observed a seasonal 
variation (high for winter months and low for summer months) of non-casein nitrogen in their study.

The casein (calculated TN - NCN) showed a cyclic pattern with highs during the winter months and low values during the summer months (Figure 30). In spite of NCN being almost constant, casein nitrogen varied due to the variation contributed by the total nitrogen. A similar seasonal variation of casein was reported by Nickerson (1960) in California. On the other hand, Franke et al. (1987) did not find any significant seasonal variation of casein in California milk in 1983.

Casein to total protein ratio $(\mathrm{CP})$ and casein to true protein ratio $(\mathrm{CPt})$ also followed a similar variation as that of the total nitrogen and casein. Lacroix et al. (1991) in their study found that $\mathrm{CP}$ and $\mathrm{CPt}$ values were high during the winters and spring. In their study, they compiled the $\mathrm{CP}$ values and variation by various researchers, and most of them showed that the high values were in winter and spring, and low ones were in summer. However, Franke et al. (1987) reported that in California milk, there was no significant variation of CP during their survey in 1983.

Total calcium also had a cyclic pattern with highs in January to April (winter - spring months) and low in May - July (summer) and again peaking up around October (Figure 31). Highest level calcium of $0.12 \%$ was observed in January 09 month, and a low level of $0.09 \%$ was observed in June 2009. Nickerson (1960) also observed similar seasonal variation of total calcium in milk during 1955 to 1958 in California. In this study, the total calcium variation followed a similar trend to that of total protein (Figure 29, Figure 30). This observation was also in line with that of Nickerson (1960) who noticed that 
milk that had the lowest average protein content also had the lowest calcium content and milk with the highest average protein had the highest calcium content.

Even though fat and total solids varied considerably between samples with a standard deviation $\pm 0.65 \%$ and $\pm 0.68 \%$ respectively (Table 9 ), there was no particular high and low values for any season. Their variation was random as shown in Figure 31. In contrast, a lot of researchers reported low fat in milk during summer and highs in winter (Ozrenk \&Inci 2008; Verdi et al. 1987; Pavan \& Gavan 2011; Heck et al. 2009; Larsen et al. 2010). Also, Heck et al. (2009) and Larsen et al. (2010) noticed that milk fat varied more with season compared to other components. They attributed this variation to change in diet during different seasons and noticed that fat varies to a greater extent with change in diet than other milk components. In California, Nickerson (1960), Bruhn \& Franke (1991), and Bruhn \& Franke (1977) observed that the fat content was significantly lower from May through August and higher from November through February. However, Frank et al. (1987) reported that he did not observe any seasonal variation of total protein in California milk in 1983. Ozrenk \&Inci (2008) and Nickerson (1960) found that the total solids also varied seasonally, with high levels in winter and low values in summer. The somatic cell count and $\mathrm{pH}$ variation did not show any seasonal patterns (Figure 32). However, Bertocchi et al. (2013) and Dohoo \& Meek (1982) have reported that the somatic counts vary seasonally (lowest counts during winter and the highest counts during the summer). They attributed the increase in somatic cells due to change in diet and heat stress. 


\section{Modeling of Milk Components for Seasonal Variation}

The results of the multiple linear regression (single cosinor) model, used to estimate the seasonal variation in milk components, is given below. More complete output for this statistical analysis and the residual plots are in Appendix 2.

Table 11. Regression analysis results of milk components

\begin{tabular}{|c|c|c|c|c|}
\hline \multirow[t]{2}{*}{ Predictors } & \multicolumn{2}{|c|}{ t-values and p-values } & \multicolumn{2}{|c|}{ Fit for the whole model } \\
\hline & Sine (week) & $\begin{array}{l}\begin{array}{l}\text { Cosine } \\
\text { (week) }\end{array} \\
\end{array}$ & $\begin{array}{c}\text { F-values and } \\
\text { p-values }\end{array}$ & $\mathbf{R}^{2}$ values $(\%)$ \\
\hline \multirow[t]{2}{*}{ Total nitrogen } & -3.73 & 10.69 & 63.40 & 63.5 \\
\hline & 0.009 & 0.000 & 0.000 & \\
\hline \multirow[t]{2}{*}{ True nitrogen } & -5.00 & 9.48 & 56.6 & 60.80 \\
\hline & 0.000 & 0.000 & 0.000 & \\
\hline \multirow[t]{2}{*}{ Casein nitrogen } & -5.55 & 12.04 & 86.71 & 70.4 \\
\hline & 0.000 & 0.000 & 0.000 & \\
\hline \multirow{2}{*}{$\begin{array}{c}\text { Casein/Total Protein } \\
\text { (CP) }\end{array}$} & -5.29 & 7.60 & 42.12 & 53.58 \\
\hline & 0.000 & 0.000 & 0.000 & \\
\hline \multirow{2}{*}{$\begin{array}{c}\text { Casein/True Protein } \\
\text { (CPt) }\end{array}$} & -3.38 & 8.51 & 41.38 & 53.13 \\
\hline & 0.001 & 0.000 & 0.000 & \\
\hline \multirow[t]{2}{*}{ Total Calcium } & 2.01 & 9.59 & 48.86 & 59.32 \\
\hline & 0.088 & 0.000 & 0.000 & \\
\hline \multirow{2}{*}{ Non- casein nitrogen } & 2.31 & -0.24 & 2.70 & 6.88 \\
\hline & 0.023 & 0.813 & 0.074 & \\
\hline \multirow{2}{*}{ Non- protein nitrogen } & 2.62 & 0.860 & 27.29 & 42.78 \\
\hline & 0.011 & 0.000 & 0.000 & \\
\hline \multirow{2}{*}{ Fat } & -1.95 & -0.04 & 1.91 & 5.04 \\
\hline & 0.055 & 0.971 & 0.156 & \\
\hline \multirow{2}{*}{ Total solids } & -2.73 & 1.26 & 4.50 & 11.11 \\
\hline & 0.008 & 0.211 & 0.014 & \\
\hline \multirow{2}{*}{$\mathrm{pH}$} & 0.150 & -0.59 & 0.19 & 0.51 \\
\hline & 0.883 & 0.554 & 0.831 & \\
\hline \multirow{2}{*}{ Somatic Cells/ $\mu 1$} & -0.57 & 0.08 & 0.16 & 0.45 \\
\hline & 0.572 & 0.938 & 0.850 & \\
\hline
\end{tabular}

After modeling these components with the linear regression model with cosine (week) or sine (week) as predictors, $\mathrm{p}$-values $<0.05$ for both or one of the predictors was obtained for total nitrogen, true protein, non-protein nitrogen, $\mathrm{CP}, \mathrm{CPt}$, and total calcium. The $\mathrm{R}^{2}$ 
$>50 \%$ (Table 11) for total nitrogen, true nitrogen, casein nitrogen, $\mathrm{CP}, \mathrm{CPt}$, and total calcium shows that more than $50 \%$ of the data fitted well in the model. The $\mathrm{R}^{2}$ value for non- protein nitrogen was $42.78 \%$ (Table 11 ), which shows that $42.78 \%$ of data fitted well in the model. These findings indicate that significant seasonal variations in total nitrogen, true nitrogen, casein, non-protein nitrogen, total calcium of casein/total protein, casein/true protein, and non-protein nitrogen in silo milk during the sampling period (July 2008 - December 2009) can be explained using the linear regression model with time as an angular variable. The model showed less than $12 \%$ variation for $\mathrm{pH}$, fat, total solids, and somatic cells; thereby, no significant seasonal variation could be explained for these components as the p-values $>0.05 \%$. The hottest months in Central Valley, California, during 2008 and 2009 were from June to September with temperatures reaching above $100^{0} \mathrm{~F}$ (refer Appendix 3). In addition, these years (2008 and 2009) had very little precipitation (refer Appendix 4). Hence, the variation of total nitrogen, casein nitrogen, non-protein nitrogen and total calcium can be attributed to longer photoperiods and high temperatures (above $100^{\circ} \mathrm{F}$ ), which causes less food intake due to heat stress during the summer months compared to the winter months. Therefore, the accuracy of fixed casein/total protein ratio often used in dairy plants to estimate casein content of milk throughout different seasons is questionable. Thus, it may be concluded that estimating casein from true protein or casein from total protein while accounting for monthly variations of total nitrogen and non-protein nitrogen should be more accurate.

Calibration of infra-red instruments has been traditionally done using total nitrogen by Kjeldahl as the reference (Barbano, 1994). A systematic bias error of $0.03 \%-0.06 \%$ total protein can be created between infra-red milk analyzers as a result of differences in the 
mean non-protein nitrogen (NPN) as a percentage of total nitrogen between calibrations. In addition, variation in NPN as a percentage of total protein can cause systematic differences as large as $0.1 \%$ protein at specific protein concentrations (Lacroix et al. 1996). Now days, mid-infra-red transmission spectroscopy is used in measurement of milk composition by Dairy Herd Improvement Association (DHIA) and payment testing laboratories. With the recent developments of technology involving near infra- red analyzer and mid Fourier Transform Infrared analyzers, which use full spectral calibration instead of the traditional calibration, minor components like urea can be measured, and the interference of NPN in calibration can be overcome (Barbano and Wojciechowski, 2012). The components of milk, especially casein, fat, $\mathrm{pH}$, and calcium have a major impact on several aspects of cheese manufacturing, cheese composition and yield (Fox \& Cogan, 2004). As seasonal variations for casein and total calcium were observed, a close monitor for these components may be beneficial to improve the quality of cheese.

\section{B. LMPS Mozzarella Analysis}

The cheese samples collected from the Central Valley, California, for the sixteen and half - month period (July 2008 - mid November 2009) were analyzed for its composition and texture five days after manufacture. A wait period of five days after manufacture was chosen because newly manufactured cheese has excessive moisture at the surface and within the body of cheese and hence will not shred well. Four to five days of ageing will allow the cheese to absorb the moisture back and thereby the shredding quality improves (Kindstedt et al., 2004; McMahon \& Oberg, 2011). The cheeses were stored at $4^{0} \mathrm{C}$ before analysis. 


\section{Analysis of LMPS Mozzarella Composition}

The average composition data for the thirty-three cheese samples collected biweekly from July 2008 to November 2009 from a plant in Central Valley California is given in Table 12.

Table 12. Descriptive statistics for LMPS mozzarella after five days of manufacture

\begin{tabular}{llllll}
\hline Cheese components & $\begin{array}{l}\text { Sample } \\
\text { size }\end{array}$ & Mean & SD & Min. & Max. \\
\hline Total Nitrogen (\%) & 33 & 3.65 & 0.12 & 3.45 & 3.88 \\
Water Soluble Nitrogen (\%) & 33 & 0.33 & 0.04 & 0.27 & 0.45 \\
Total Solids (\%) & 33 & 51.98 & 0.60 & 50.37 & 52.99 \\
Moisture (\%) & 33 & 48.02 & 0.60 & 47.01 & 49.63 \\
Fat (\%) & 33 & 21.33 & 0.71 & 19.58 & 22.27 \\
Fat in Dry Matter (\%) & 33 & 41.05 & 1.51 & 36.943 & 43.08 \\
Total calcium (\%) & 33 & 0.59 & 0.03 & 0.50 & 0.63 \\
Water Soluble Calcium (\%) & 33 & 0.27 & 0.02 & 0.24 & 0.33 \\
Salt (\%) & 33 & 2.14 & 0.10 & 2.36 & 1.88 \\
pH & 33 & 5.47 & 0.04 & 5.41 & 5.53 \\
\hline
\end{tabular}

The cheese composition (total nitrogen, water soluble nitrogen, total solids, moisture, fat in dry matter (FDM), total calcium, water soluble calcium, salt, and $\mathrm{pH}$ ) was plotted versus month. The curves in the graphs (Figure 33, Figure 34 and Figure 36) just trace the trend and are not the fitted curve of the linear regression model used in analysis. 


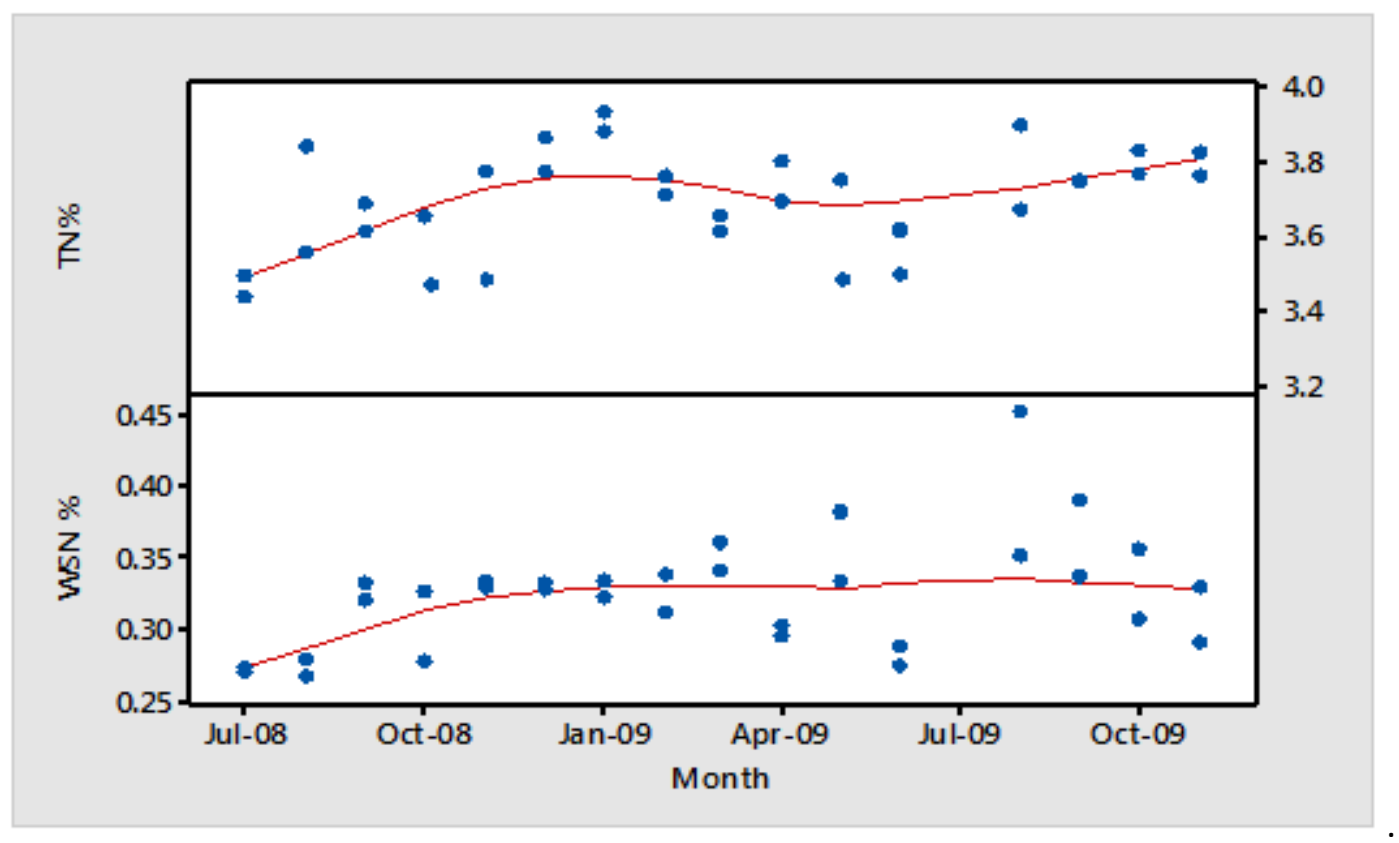

Figure 33. Variation of cheese total nitrogen (TN\%), water soluble nitrogen (WSN\%)

The average total nitrogen content of the cheese sample was $3.6452 \pm 0.12 \%$ (Table 12), which has a mean of $22.9 \%$ protein. The mean protein content reported by other researchers was 26\% (Feeney et al, 2001; Joshi et al., 2004; Banville et al., 2013). However, Guinee et al. (2002) reported a lower mean protein content of $23.52 \%$ in directly acidified mozzarella, which was close to the average protein content of $22.9 \%$ from this study. The total nitrogen content had a maximum of 3.88\% (Table 12), which was seen around winter months (December 2008 - January 2009) (Figure 33). The total nitrogen content was low (3.43\%) in summer months (July - September 2008, May -July 2009) (Figure 33). As a dip in the nitrogen content was observed during May and June 2009, changes during manufacturing (non-fat dry milk was added) were made to increase protein content in August 2009. The water soluble nitrogen (WSN \%) had a mean of $0.33 \%$ (Table 12), which was $8.8 \%$ of the total nitrogen. The WSN was low during 2008 summer but remained almost constant during the remaining study (Figure 33). 


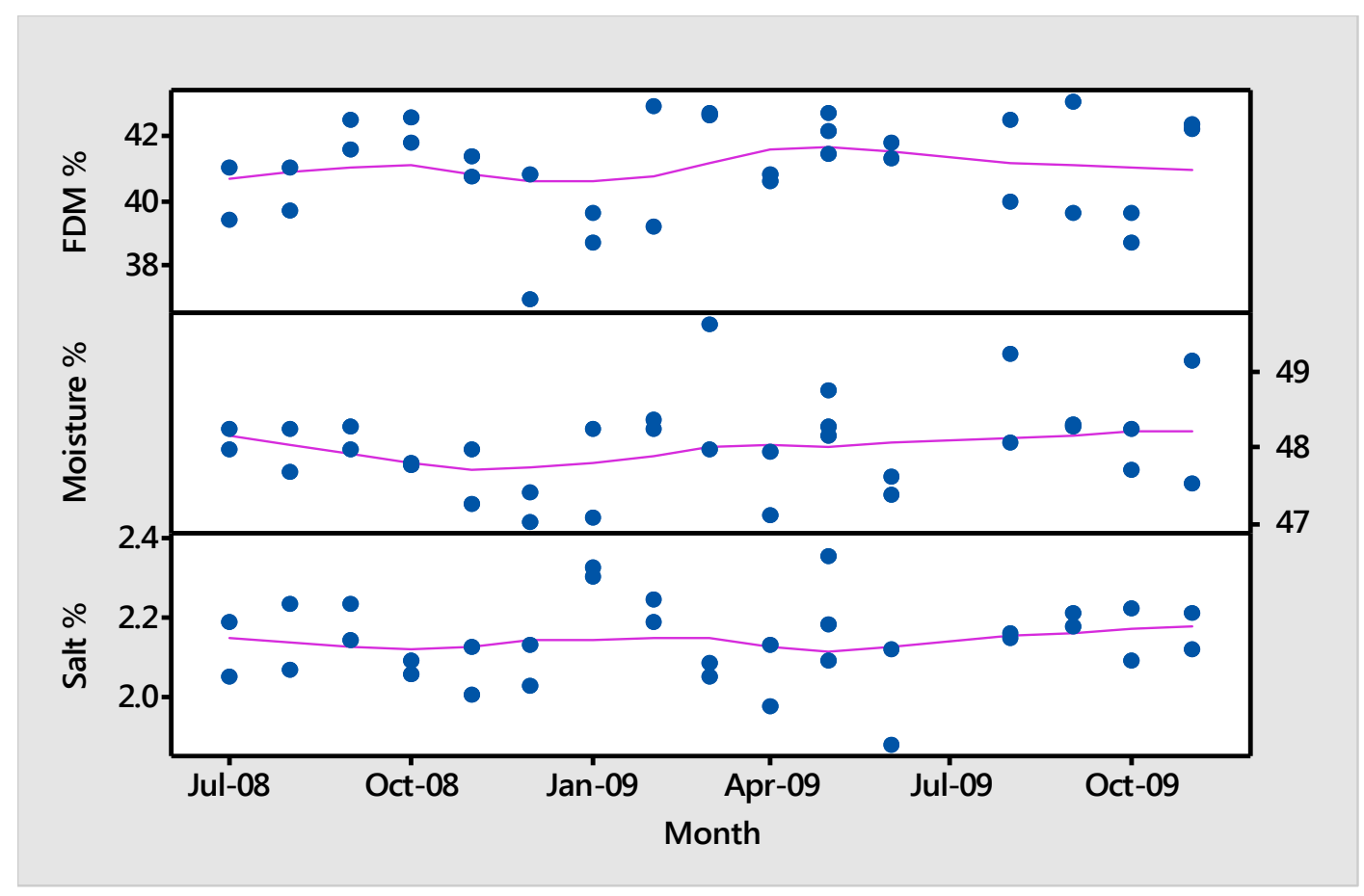

Figure 34. Variation of cheese fat in dry matter (FDM \%), moisture (\%) and salt (\%)

The mean \pm standard deviation for moisture and fat in dry matter (FDM) of LMPS mozzarella was $48.024 \pm 0.599 \%$ and $41.05 \pm 1.508 \%$, respectively (Table 12 ). The percent moisture content and FDM were within the limits for standard of identity of LMPS Mozzarella specified by CFR 133.157. Very high and low levels of salt can decrease protein solubility and affect the melting properties. A $2 \%$ salt content is the optimal level as it increases the casein solubility to a sufficient level, thereby giving the required meltability in mozzarella (McMahon \& Oberg, 2011). The mean \pm standard deviation of salt content was found to be $2.14 \pm 0.10 \%$ (Table 12). From Figure 34, the FDM, moisture content and salt were almost constant during the entire sampling period. 


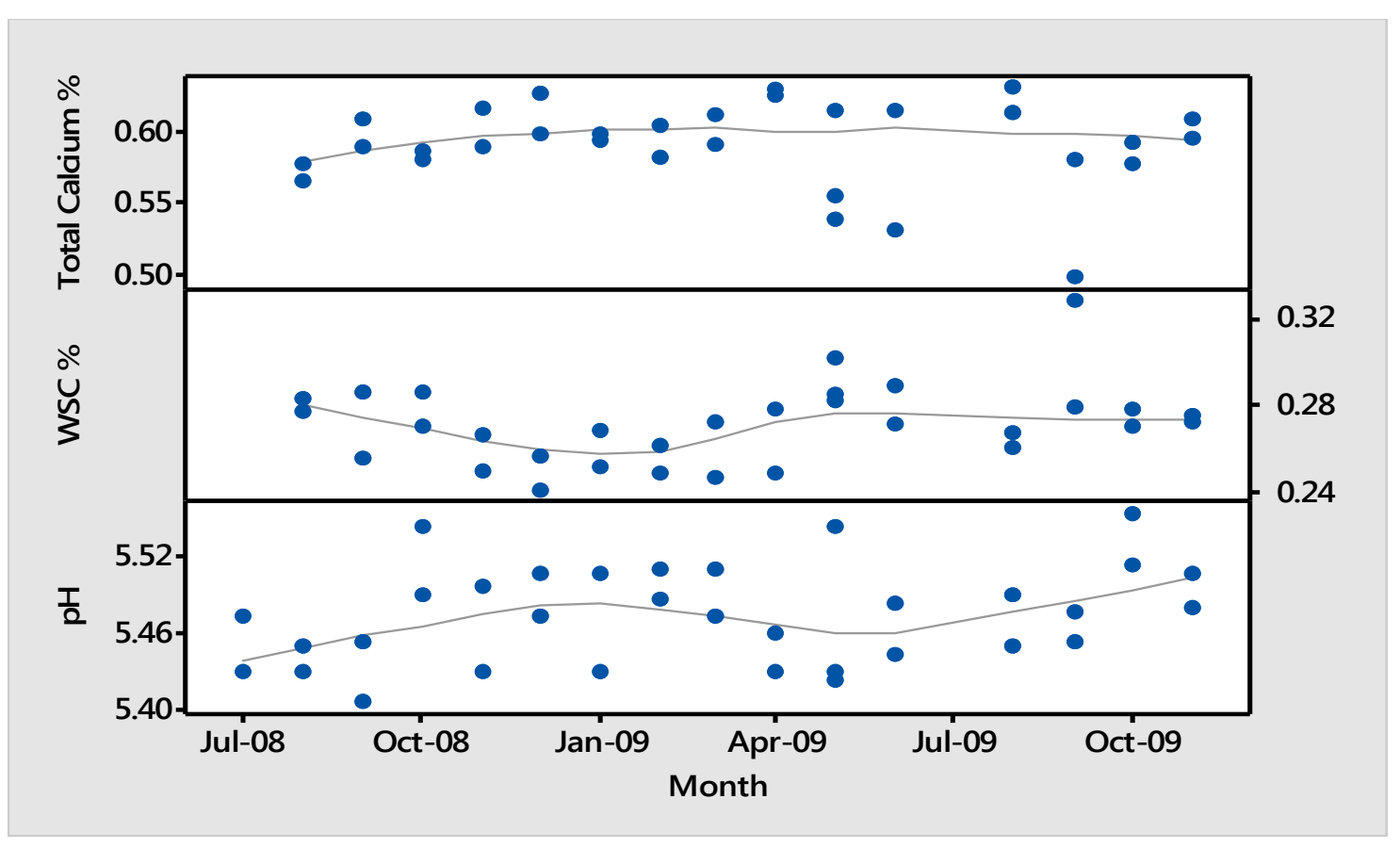

Figure 35. Variation of cheese total calcium (\%), water soluble calcium (WSC \%), pH

The total calcium had a mean \pm standard deviation of $0.5911 \pm 0.0301 \%$ (Table 12). The total calcium levels in cultured low moisture mozzarella were $0.673 \%$ (Feeney et al., 2001). However, the total calcium levels in this study were close to that of $0.578 \%$, which was obtained when the milk was pre-acidified to $\mathrm{pH} 5.8$ with citric acid (Metzger et al., 2000a). Even though the protein and calcium levels were close that of the directly acidified low moisture mozzarella, the LMPS Mozzarella in this study was made by adding cultures. The total calcium content was relatively constant during the entire sampling period (Figure 35).

The mean \pm standard deviation for water soluble calcium (WSC) was $0.2713 \pm 0.0181 \%$ (Table 12). The WSC \% obtained by Metzger et al. (2000b) was between $40 \%-50 \%$ of the total calcium. The WSC (\%) was measured using the method followed by Metzger $e t$ al. (2000b), and the average WSC\% was found to be $47.36 \%$ of the total calcium. The 
water soluble calcium levels were low during the fall and winter months and were found to increase during the spring and summer (Figure 35).

The $\mathrm{pH}$ and levels of calcium in the curd during the stretching process impacts the ability of the curd to plasticize and stretch. In order to plasticize and obtain the required stretch, a high calcium content curd that is $3.0 \%$ of protein is stretched at a higher $\mathrm{pH}(5.6-5.7)$, and low calcium content of $2.2 \%$ of protein is stretched at a lower $\mathrm{pH}$ of $5.1-5.3$ (Kindstedt et al., 2004). The stretching pH usually determines the final pH of the cheese. The amount of calcium associated with casein available to crosslink the para-casein matrix influences the ability of the curd to plasticize in hot water and reorganize into a unidirectional fibrous structure (Kindstedt et al., 2004; Guinee et al., 2002). The total calcium content in this study was $2.5 \%$ of protein content (calculated using the formula (mean total calcium/mean protein content) $* 100)$, and the average $\mathrm{pH}$ was $5.4 \pm 0.038$ which was not very low or high. From Figure 35, a slight increase of pH during the fall and winter months compared to the summer months was observed. From Figure 35, the $\mathrm{pH}$ was found to vary inversely with WSC (\%). In addition, a significant moderate negative correlation $(\mathrm{r}=-0.447$ with a $\mathrm{p}$-value of 0.030 (Table 13)) between $\mathrm{pH}$ and WSC \% indicated that as the $\mathrm{pH}$ increased, WSC (\%) decreased, and vice versa. The distribution of calcium between the soluble and insoluble states is a function of $\mathrm{pH}$ because at lower $\mathrm{pH}$, the calcium moves into the soluble phase (Kindstedt et al., 2004; Guinee et al., 2002; Joshi et al., 2004). The pH of the cheese was found to influence the amount of water soluble calcium and also as a drop in $\mathrm{pH}$ and increase in water soluble calcium in May 2009 was observed. As the total calcium of the curd and distribution of the calcium between the soluble and insoluble influences the firmness of cheese and 
hence the texture of cheese (Kindstedt et al., 2004), the $\mathrm{pH}$ of the finished cheese was increased above 5.45 from August 2009 to prevent the water soluble calcium from decreasing.

Table 13. Correlation between LMPS mozzarella compositions

\begin{tabular}{|c|c|c|c|c|c|c|c|c|}
\hline $\begin{array}{l}\text { Cheese } \\
\text { parameters }\end{array}$ & WSN & $\begin{array}{l}\text { Total } \\
\text { solids }\end{array}$ & Fat & FDM & $\begin{array}{c}\text { Total } \\
\text { Ca }\end{array}$ & WSC & Salt & $\mathbf{p H}$ \\
\hline \multirow{2}{*}{$\begin{array}{l}\text { Total } \\
\text { nitrogen }\end{array}$} & 0.299 & 0.071 & -0.364 & -0.335 & -0.088 & -0.169 & 0.145 & -0.062 \\
\hline & 0.091 & 0.696 & 0.041 & 0.041 & 0.639 & 0.364 & 0.419 & 0.733 \\
\hline \multirow[t]{2}{*}{ WSN } & & -0.528 & 0.090 & 0.294 & -0.063 & 0.025 & 0.239 & -0.093 \\
\hline & & 0.002 & 0.623 & 0.097 & 0.735 & 0.894 & 0.180 & 0.608 \\
\hline \multirow[t]{2}{*}{ Total solids } & & & -0.163 & -0.294 & -0.205 & -0.03 & -0.210 & 0.153 \\
\hline & & & 0.373 & 0.097 & 0.269 & 0.870 & 0.242 & 0.395 \\
\hline \multirow[t]{2}{*}{ Fat } & & & & 0.950 & -0.059 & 0.331 & -0.158 & 0.178 \\
\hline & & & & 0.000 & 0.756 & 0.069 & 0.380 & 0.322 \\
\hline \multirow[t]{2}{*}{ FDM } & & & & & -0.288 & 0.304 & -0.075 & 0.110 \\
\hline & & & & & 0.116 & 0.097 & 0.678 & 0.544 \\
\hline \multirow[t]{2}{*}{ Total Ca } & & & & & & -0.639 & -0.076 & -0.319 \\
\hline & & & & & & 0.000 & 0.683 & 0.080 \\
\hline \multirow[t]{2}{*}{ WSC } & & & & & & & -0.028 & -0.447 \\
\hline & & & & & & & 0.882 & 0.030 \\
\hline Salt & & & & & & & & -0.203 \\
\hline
\end{tabular}

Cell content: Pearson correlation coefficient on top and p-value on the bottom. The yellow markings indicate significant correlation.

\section{Textural Analysis of LMPS Mozzarella}

The LMPS Mozzarella samples were analyzed for un-melted textural properties such as textural profile analysis (hardness, cohesiveness, springiness, and chewiness), loss in shredder, and aggregation index for the 18-month period. The average textural data obtained during this study is given in Table 14. 
Table 14. Descriptive statistics for textural properties of mozzarella after five days of manufacture

\begin{tabular}{llllll}
\hline $\begin{array}{l}\text { Textural } \\
\text { Properties }\end{array}$ & $\begin{array}{l}\text { Sample } \\
\text { size }\end{array}$ & Mean & SD & Min. & Max. \\
\hline Hardness (g) & 33 & 4135 & 624 & 3088 & 5502 \\
Cohesiveness & 33 & 0.51 & 0.045 & 0.42 & 0.66 \\
Springiness & 33 & 0.67 & 0.049 & 0.58 & 0.75 \\
Chewiness (g) & 33 & 1445.5 & 344.4 & 852.4 & 2229.5 \\
$\begin{array}{l}\text { Loss in } \\
\text { shredder (\%) }\end{array}$ & 33 & 9.71 & 1.395 & 7.303 & 12.76 \\
$\begin{array}{l}\text { Aggregation } \\
\text { Index }\end{array}$ & 33 & 6.04 & 0.22 & 5.49 & 6.38 \\
\hline
\end{tabular}

The textural properties were plotted versus month (Figure 36, Figure 37), and correlation between cheese textural parameters and cheese composition (Table 15) and between cheeses' textural properties were done (Table 16). The curves in the graphs (Figure 36, Figure 37) just trace the trend and are not the fitted curve of the linear regression model used in analysis.

Table 15. Correlation between cheese composition and cheese texture

\begin{tabular}{lcccccccc}
\hline $\begin{array}{c}\text { Cheese } \\
\text { parameters }\end{array}$ & $\begin{array}{c}\text { Total } \\
\text { nitrogen }\end{array}$ & WSN & Moisture & FDM & $\begin{array}{c}\text { Total } \\
\text { Ca }\end{array}$ & WSC & Salt & pH \\
\hline Hardness & 0.876 & 0.211 & -0.189 & -0.363 & 0.369 & -0.250 & 0.083 & 0.274 \\
& 0.000 & 0.238 & 0.292 & 0.038 & 0.040 & 0.174 & 0.646 & 0.122 \\
Cohesiveness & 0.322 & -0.093 & -0.188 & -0.312 & 0.355 & -0.403 & -0.081 & 0.172 \\
& 0.067 & 0.608 & 0.295 & -0.079 & 0.049 & 0.025 & 0.654 & 0.340 \\
Springiness & 0.405 & -0.179 & -0.353 & -0.436 & 0.426 & -0.515 & -0.011 & 0.110 \\
& 0.019 & 0.318 & 0.044 & 0.011 & 0.017 & 0.003 & 0.950 & 0.541 \\
Chewiness & 0.782 & 0.060 & -0.313 & -0.496 & 0.470 & -0.475 & 0.020 & -0.280 \\
& 0.000 & 0.740 & 0.076 & 0.003 & 0.008 & 0.007 & 0.914 & 0.115 \\
AGI & -0.353 & 0.018 & 0.356 & 0.302 & -0.126 & 0.194 & 0.193 & -0.081 \\
& 0.044 & 0.920 & 0.042 & 0.088 & 0.501 & 0.295 & 0.281 & 0.653 \\
& -0.489 & 0.151 & 0.204 & 0.335 & -0.402 & 0.471 & -0.100 & -0.238 \\
Loss in & 0.003 & 0.418 & 0.272 & 0.057 & 0.025 & 0.007 & 0.593 & 0.197 \\
\hline shredder & &
\end{tabular}

Cell content: Pearson correlation coefficient on top and p-value on bottom. The yellow markings indicate significant correlation. 


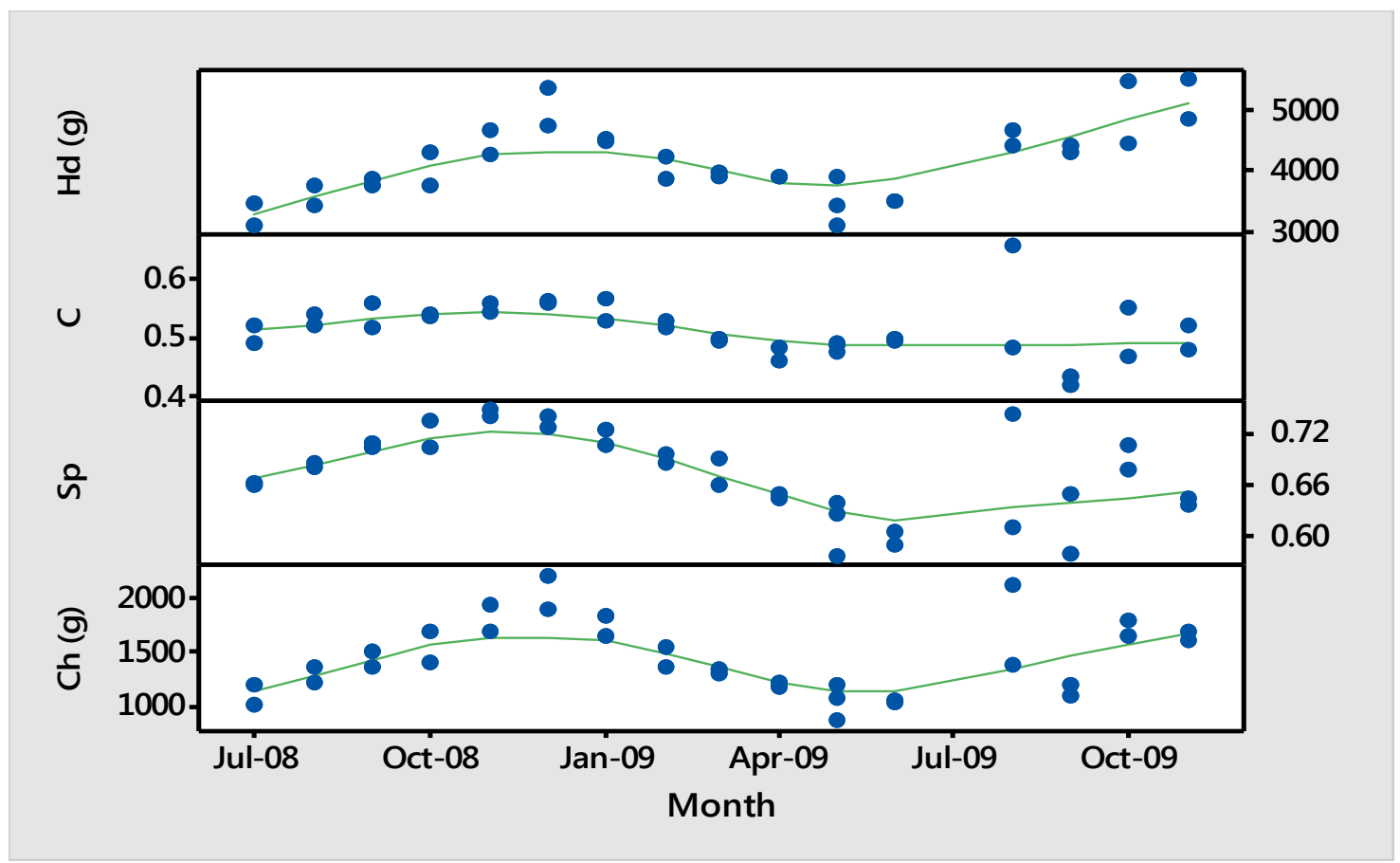

\section{Figure 36. Variation cheese TPA (hardness $(H(g))$, cohesiveness $(C)$, springiness} (Sp), and chewiness $(\mathrm{Ch}(\mathrm{g}))$

The TPA hardness, springiness, and chewiness were found to have a similar variation.

They had low values in summer months and high ones during winter (Figure 36). The mean \pm standard deviation of hardness, springiness, and chewiness is given in Table 14 . Cohesiveness was found to remain relatively constant (Figure 36). Hardness and chewiness had a significant strong positive correlation with total nitrogen content of cheese $(\mathrm{r}>0.7$ and $p$-value $<0.05)$ (Table 15). This indicates that with an increase in total protein content of cheese the firmness and chewiness of cheese were found to increase. During winter, the total nitrogen content in cheese was $0.45 \%$ higher than summer (Figure 36, Table 12) and also the hardness and chewiness of cheese was higher by $2414 \mathrm{~g}$ and $1337.1 \mathrm{~g}$, respectively (Figure 36, Table 14). Fat in dry matter (FDM) also had a significant weak negative correlation with hardness, springiness, and chewiness ($0.7<\mathrm{r}>-0.3$ and $p$-value $<0.05$ ) (Table 15), indicating that as fat content decreased the 
TPA hardness, springiness and chewiness increased. Though there was a variation of fat in dry matter by $6.14 \%$ (Table 12 ) during the sampling period, no seasonal variation was observed (Figure 34). Also, moisture had a weak negative correlation with springiness and chewiness $(-0.7<\mathrm{r}>-0.3$ and $p-$ value $<0.05)$ (Table 15). As moisture content in cheese decreased, the springiness and chewiness were found to increase. Though there was a variation of moisture content by $2.59 \%$ (Table 12) during the sampling period, no seasonal variation was observed (Figure 34). Total calcium had a significant positive weak correlation $(0.7<\mathrm{r}>0.3$ and $p$-value $<0.05)$ (Table 15) with hardness, cohesiveness, springiness and chewiness, as total calcium increased the hardness, springiness and chewiness increased. Though there was a variation of total calcium by 0.14\% (Table 12) during the sampling period, no seasonal variation was observed (Figure 35). Cohesiveness, springiness and chewiness were found to decrease with water soluble calcium. i.e., WSC had a significant weak negative correlation $(-0.7>\mathrm{r}>-0.3$ and $p$-value $<0.05$ ) (Table 15) with cohesiveness, springiness and chewiness. The hardness of cheese was not found to have any significant correlation with the WSC (\%). During the sampling period, the water soluble calcium varied by $0.08 \%$ (Table 12); higher values were observed during summer and low ones in winter (Figure 35). Therefore, most of the TPA characteristics of cheese were dependent on the cheese total nitrogen, total calcium, FDM, water soluble calcium, and moisture content. 


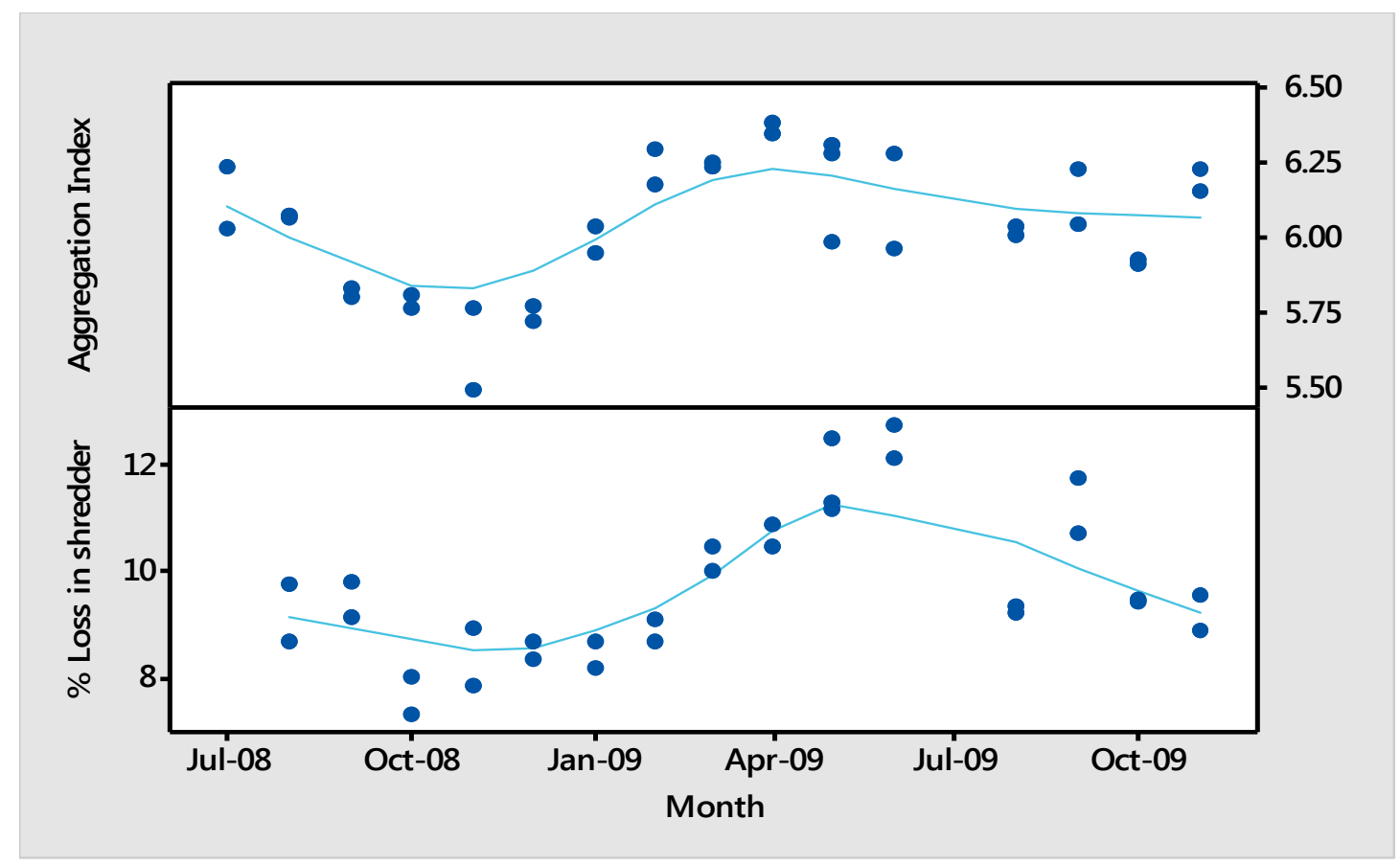

Figure 37. Variation of aggregation index (AGI) and \% loss in shredder

Aggregation index (AGI) is an empirical test to measure matting behavior based on the ability of the cheese to pass through a stack of sieves of decreasing mesh size. Sticky cheese that mats excessively is retained by larger sieves whereas the cheese particles that are free flowing may penetrate to the bottom of the stack. The larger the AGI, more the cheese aggregates (Kindstedt et al., 2004). From Figure 37, AGI and loss in shredder increased during summer months and decreased during winter months. This shows that in the summer months, cheese aggregated more than the winter months. From Table 15, there was a negative weak correlation $(-0.7<\mathrm{r}>-0.3$ and $p$-value $<0.05)$ between percent loss in shredder and total nitrogen, total calcium, and a weak positive correlation $(0.3>r>$ 0.7 and $p$-value $<0.05)$ between percentage loss in shredder and FDM, water soluble calcium. This indicates that as total nitrogen and total calcium increased the percentage loss in shredder decreased, and when FDM and water soluble calcium increased the percentage loss in shredder increased. Hence a variation of $0.45 \%$ of total nitrogen during 
the winter compared to summer months brought about a loss of 5.45\% (Table 14) during shredding of cheese between the different seasons. However total calcium had a variation of during of $0.13 \%$ during the sampling period, but the variation was not seasonal. Kindstedt et al. (2004) reported that in low moisture mozzarella, high moisture content and fat content (FDM of 45\%) cause cheese to clog in the shredder. In this study, we did find that higher FDM caused more loss during shredding. There was no significant correlation between moisture content and shredding loss. However, many researchers have reported that one of the reasons high moisture mozzarella cannot be shredded was due to the moisture content, which is greater than $52 \%$. In this study, there was no significant correlation between moisture and shredding loss because the maximum moisture content of $49.63 \%$ (Table 12) did not exceed the threshold moisture content of $52 \%$; therefore, it's the association between shredding and moisture content could not be observed. Hence, the loss in shredder was affected by the cheese composition, mainly the total nitrogen content, FDM, total calcium, and water soluble calcium. Like \% loss in shredder, total nitrogen and water soluble calcium varied seasonally. Total nitrogen was $0.45 \%$ higher in winter (Figure33, Table 12), and WSC was $0.14 \%$ (Figure 35, Table 12) higher in summer. Though during the sampling period FDM and moisture had a variation of $6.14 \%$ and $2.59 \%$ respectively (Table 12 ), their variation was found to be random and not seasonal (Figure 34).

From Table 15, there was a significant weak negative correlation $(-0.7<\mathrm{r}>-0.3$ and $\mathrm{p}-$ value $<0.05$ ) between AGI and total protein content, and a significant positive correlation between moisture and AGI. As the moisture increased, there was more aggregation, and also as the total protein content increased the cheese aggregated less. 
Therefore, the cheese aggregation was mostly affected by the total nitrogen and moisture.

The AGI was higher in winter by 0.8 than summer (Table 14, Figure 37).

Table 16. Correlation between cheese textural parameters

\begin{tabular}{lccccc}
\hline & Cohesiveness & Springiness & Chewiness & AGI & $\begin{array}{c}\text { Loss in } \\
\text { shredder }\end{array}$ \\
\hline Hardness & 0.141 & 0.369 & 0.777 & -0.365 & -0.516 \\
& 0.435 & 0.035 & 0.000 & 0.037 & 0.003 \\
Cohesiveness & & 0.718 & 0.703 & -0.501 & -0.590 \\
& & 0.000 & 0.000 & 0.003 & 0.000 \\
Springiness & & & 0.801 & -0.652 & -0.824 \\
& & & 0.000 & 0.000 & 0.000 \\
Chewiness & & & & -0.618 & -0.774 \\
& & & & 0.000 & 0.000 \\
AGI & & & & & 0.574 \\
& & & & & 0.001 \\
\hline
\end{tabular}

Cell content: Pearson correlation coefficient on top and p-value on the bottom. The yellow markings indicate significant correlation.

According to Chen (2003), mozzarella cheese to be shredded must be firm in texture and not adhesive. From Table 16, there was a weak significant negative correlation $(-0.7<\mathrm{r}>$ -0.3 and $\mathrm{p}-$ value $<0.05$ ) between TPA parameters (hardness, cohesiveness, springiness, and chewiness) and percentage loss in shredder. The same trend was observed for the AGI and TPA parameters, showing that firmer, more cohesive, springy, and chewy cheese aggregated less, and thus, the loss during shredding was less.

\section{Effect of Milk Composition on Cheese Composition and Cheese Texture}

Correlation analyses were done between milk composition and cheese composition and texture using Minitab version 17.0 from July 2008 to April 2009. The correlation analysis was done only for a ten- month period because from May 2009 changes in the production protocol of cheese were done to increase the firmness of cheese, thereby reducing the loss 
during shredding. The corresponding week milk and cheese samples were correlated for the ten- month period, and the results are summarized in Table 17 and Table 18.

Table 17. Correlation between cheese composition and milk composition

\begin{tabular}{|c|c|c|c|c|c|c|c|c|}
\hline \multirow[b]{2}{*}{$\begin{array}{c}\text { Milk } \\
\text { Components }\end{array}$} & \multicolumn{8}{|c|}{ Cheese Composition } \\
\hline & TN & WSN & Moisture & FDM & $\begin{array}{c}\text { Total } \\
\text { Ca }\end{array}$ & WSC & Salt & $\mathbf{p H}$ \\
\hline TN & $\begin{array}{l}0.725 \\
0.003\end{array}$ & $\begin{array}{l}0.263 \\
0.262\end{array}$ & $\begin{array}{c}-0.549 \\
0.012\end{array}$ & $\begin{array}{l}-0.552 \\
0.012\end{array}$ & $\begin{array}{l}0.050 \\
0.845\end{array}$ & $\begin{array}{l}-0.171 \\
0.498\end{array}$ & $\begin{array}{r}-0.048 \\
0.841\end{array}$ & $\begin{array}{r}-0.090 \\
0.707\end{array}$ \\
\hline True $\mathbf{N}$ & $\begin{array}{l}0.635 \\
0.003\end{array}$ & $\begin{array}{l}0.187 \\
0.431\end{array}$ & $\begin{array}{c}-0.531 \\
0.016\end{array}$ & $\begin{array}{r}-0.522 \\
0.018\end{array}$ & $\begin{array}{r}-0.012 \\
0.961\end{array}$ & $\begin{array}{l}-0.242 \\
0.333\end{array}$ & $\begin{array}{c}-0.056 \\
0.816\end{array}$ & $\begin{array}{r}-0.100 \\
0.675\end{array}$ \\
\hline NPN & $\begin{array}{l}0.728 \\
0.000\end{array}$ & $\begin{array}{l}0.400 \\
0.080\end{array}$ & $\begin{array}{l}-0.505 \\
0.023\end{array}$ & $\begin{array}{l}-0.499 \\
0.025\end{array}$ & $\begin{array}{l}0.306 \\
0.095\end{array}$ & $\begin{array}{l}0.073 \\
0.773\end{array}$ & $\begin{array}{r}-0.017 \\
0.944\end{array}$ & $\begin{array}{l}0.083 \\
0.727\end{array}$ \\
\hline NCN & $\begin{array}{l}0.056 \\
0.814\end{array}$ & $\begin{array}{l}0.014 \\
0.953\end{array}$ & $\begin{array}{l}-0.454 \\
0.045\end{array}$ & $\begin{array}{l}-0.296 \\
0.205\end{array}$ & $\begin{array}{l}0.590 \\
0.010\end{array}$ & $\begin{array}{l}0.327 \\
0.185\end{array}$ & $\begin{array}{l}0.103 \\
0.665\end{array}$ & $\begin{array}{l}0.397 \\
0.083\end{array}$ \\
\hline Casein & $\begin{array}{l}0.744 \\
0.000\end{array}$ & $\begin{array}{r}-0.308 \\
0.187\end{array}$ & $\begin{array}{l}-0.410 \\
0.072\end{array}$ & $\begin{array}{l}-0.464 \\
0.039\end{array}$ & $\begin{array}{r}-0.061 \\
0.809\end{array}$ & $\begin{array}{l}-0.262 \\
0.293\end{array}$ & $\begin{array}{c}-0.086 \\
0.718\end{array}$ & $\begin{array}{l}-0.186 \\
0.433\end{array}$ \\
\hline $\mathbf{C P t}$ & $\begin{array}{l}0.648 \\
0.002\end{array}$ & $\begin{array}{l}0.319 \\
0.171\end{array}$ & $\begin{array}{l}-0.125 \\
0.598\end{array}$ & $\begin{array}{l}-0.255 \\
0.277\end{array}$ & $\begin{array}{r}-0.217 \\
0.388\end{array}$ & $\begin{array}{l}-0.355 \\
0.148\end{array}$ & $\begin{array}{c}-0.136 \\
0.568\end{array}$ & $\begin{array}{r}-0.307 \\
0.188\end{array}$ \\
\hline $\mathbf{C P}$ & $\begin{array}{l}0.759 \\
0.000\end{array}$ & $\begin{array}{l}0.393 \\
0.086\end{array}$ & $\begin{array}{r}-0.217 \\
0.358\end{array}$ & $\begin{array}{r}-0.337 \\
0.146\end{array}$ & $\begin{array}{r}-0.109 \\
0.667\end{array}$ & $\begin{array}{c}-0.248 \\
0.321\end{array}$ & $\begin{array}{r}-0.113 \\
0.635\end{array}$ & $\begin{array}{c}-0.258 \\
0.272\end{array}$ \\
\hline Fat & $\begin{array}{c}-0.149 \\
0.543\end{array}$ & $\begin{array}{r}-0.115 \\
0.640\end{array}$ & $\begin{array}{l}0.166 \\
0.498\end{array}$ & $\begin{array}{l}0.411 \\
0.080\end{array}$ & $\begin{array}{r}-0.524 \\
0.031\end{array}$ & $\begin{array}{c}-0.229 \\
0.377\end{array}$ & $\begin{array}{r}-0.037 \\
0.881\end{array}$ & $\begin{array}{l}0.125 \\
0.610\end{array}$ \\
\hline TS & $\begin{array}{l}0.064 \\
0.394\end{array}$ & $\begin{array}{r}-0.005 \\
0.984\end{array}$ & $\begin{array}{l}0.088 \\
0.727\end{array}$ & $\begin{array}{l}0.261 \\
0.281\end{array}$ & $\begin{array}{l}-0.518 \\
0.033\end{array}$ & $\begin{array}{c}-0.290 \\
0.258\end{array}$ & $\begin{array}{l}0.009 \\
0.862\end{array}$ & $\begin{array}{r}-0.064 \\
0.794\end{array}$ \\
\hline Total Ca & $\begin{array}{l}0.624 \\
0.003\end{array}$ & $\begin{array}{l}0.577 \\
0.008\end{array}$ & $\begin{array}{l}-0.176 \\
0.450\end{array}$ & $\begin{array}{l}-0.219 \\
0.355\end{array}$ & $\begin{array}{l}0.430 \\
0.045\end{array}$ & $\begin{array}{l}0.252 \\
0.314\end{array}$ & $\begin{array}{l}0.246 \\
0.297\end{array}$ & $\begin{array}{c}-0.056 \\
0.81\end{array}$ \\
\hline $\begin{array}{l}\text { Somatic } \\
\text { cells } / \mu \mathrm{L}\end{array}$ & $\begin{array}{l}0.339 \\
0.144\end{array}$ & $\begin{array}{l}-0.098 \\
0.680\end{array}$ & $\begin{array}{l}-0.344 \\
0.137\end{array}$ & $\begin{array}{l}-0.231 \\
0.328\end{array}$ & $\begin{array}{r}-0.281 \\
0.258\end{array}$ & $\begin{array}{l}-0.191 \\
0.447\end{array}$ & $\begin{array}{l}0.007 \\
0.977\end{array}$ & $\begin{array}{l}0.252 \\
0.283\end{array}$ \\
\hline pH & $\begin{array}{r}-0.297 \\
0.213\end{array}$ & $\begin{array}{c}-0.411 \\
0.072\end{array}$ & $\begin{array}{r}-0.401 \\
0.080\end{array}$ & $\begin{array}{r}-0.047 \\
0.846\end{array}$ & $\begin{array}{l}0.189 \\
0.453\end{array}$ & $\begin{array}{l}0.112 \\
0.657\end{array}$ & $\begin{array}{l}0.056 \\
0.813\end{array}$ & $\begin{array}{l}0.331 \\
0.154\end{array}$ \\
\hline
\end{tabular}

Cell content: Pearson correlation coefficient (r) on top and $p-v a l u e$ on the bottom. The yellow -markings indicate significant correlation.

The raw milk quality, especially the casein, $\mathrm{pH}$, total calcium, fat, and somatic cells, has an important impact on the quality and yield of cheese (Barbano, 1987; Kindstedt et al., 2004). Cheese milk was standardized to a ratio of casein to fat of 1.2 to get a good yield and meet the standard of identity of LMPS Mozzarella (Rankin et al., 2006). In cheese making, casein plays an important role in cheese composition, texture, and yield. It forms 
the structural network in which fat and moisture are trapped. The formation and properties of the coagulum derived from casein network determines the efficiency of milk constituents' retention in cheese (Walstra et al., 2006). Therefore, a significant strong positive correlation $(\mathrm{r}>0.7$ and $p$-value $<0.05)$ (Table 17) was observed between total nitrogen, true nitrogen, casein, non-protein nitrogen content and casein to total protein (CP) of milk and total nitrogen content of cheese. Also, there was a moderate positive correlation between $(0.7<\mathrm{r}>0.3$ and $p$-value $<0.05)$ (Table 17$)$ between total calcium true nitrogen, and casein to true protein $(\mathrm{CPt})$ ratio and total nitrogen content of cheese. From Table 17, there was a moderate positive correlation between $(0.7<\mathrm{r}>0.3$ and $p$ value $<0.05$ ) between total calcium in milk and cheese. From Table 18, milk total nitrogen, true nitrogen NPN, casein, $\mathrm{CP}, \mathrm{CPt}$ and had a significant strong to moderate positive correlation with the TPA characteristics of cheese $(\mathrm{r}>0.6$ and $p$-value $<0.05)$. Also, a significant strong moderate negative correlation $(-0.8<\mathrm{r}>-0.4$ and $\mathrm{p}$ - value $<$ 0.05) between milk total nitrogen, true nitrogen NPN, casein, $\mathrm{CP}, \mathrm{CPt} N P N$, casein, $\mathrm{CP}$, and CPt with loss in shredder and AGI were observed. The total calcium content in milk correlated positively $(r>0.4$, p-value $>0.2)$ (Table 18) with hardness in cheese. As the total nitrogen content, true nitrogen, casein and non- protein content of milk varied by $0.06 \%, 0.066 \% 0.53 \%$ and $0.019 \%$ respectively (Table 9 ), there was variation of $0.45 \%$ of total nitrogen (Table 12), 5.45\% loss in shredder, 0.90 of AGI in cheese between seasons (Table 14), with higher values being in summer and lower ones in summer. In milk, the variation of NPN over different seasons was found to have an association on the total nitrogen content, casein, and true nitrogen, thereby influencing the $\mathrm{CP}$ and $\mathrm{CPt}$ ratios. 
As the fat in silo milk was reduced to $2 \%$ fat, there was no correlation between fat in silo milk and FDM in cheese. There was a significant moderate positive correlation $(0.7<\mathrm{r}>$ 0.3 and $p$-value $<0.05$ ) between total calcium in milk and total calcium, water soluble nitrogen, and total nitrogen in cheese.

Table 18. Correlation between milk composition and cheese texture

\begin{tabular}{|c|c|c|c|c|c|c|}
\hline \multirow[b]{2}{*}{$\begin{array}{l}\text { Milk } \\
\text { Components }\end{array}$} & \multicolumn{6}{|c|}{ Cheese Texture } \\
\hline & Hardness & Cohesiveness & Springiness & Chewiness & AGI & $\begin{array}{c}\text { Loss in } \\
\text { Shredder }\end{array}$ \\
\hline $\mathbf{T N}$ & $\begin{array}{l}0.805 \\
0.000\end{array}$ & $\begin{array}{l}0.664 \\
0.001\end{array}$ & $\begin{array}{l}0.734 \\
0.000\end{array}$ & $\begin{array}{l}0.840 \\
0.000\end{array}$ & $\begin{array}{r}-0.579 \\
0.007\end{array}$ & $\begin{array}{r}-0.525 \\
0.025\end{array}$ \\
\hline NPN & $\begin{array}{l}0.853 \\
0.025\end{array}$ & $\begin{array}{l}0.601 \\
0.005\end{array}$ & $\begin{array}{l}0.698 \\
0.001\end{array}$ & $\begin{array}{l}0.866 \\
0.000\end{array}$ & $\begin{array}{l}-0.613 \\
0.004\end{array}$ & $\begin{array}{c}-0.476 \\
0.046\end{array}$ \\
\hline NCN & $\begin{array}{l}0.252 \\
0.283\end{array}$ & $\begin{array}{l}-0.073 \\
0.761\end{array}$ & $\begin{array}{l}-0.054 \\
0.823\end{array}$ & $\begin{array}{l}-0.089 \\
0.621\end{array}$ & $\begin{array}{l}0.077 \\
0.748\end{array}$ & $\begin{array}{l}0.116 \\
0.647\end{array}$ \\
\hline True $\mathbf{N}$ & $\begin{array}{l}0.721 \\
0.000\end{array}$ & $\begin{array}{l}0.644 \\
0.002\end{array}$ & $\begin{array}{l}0.686 \\
0.001\end{array}$ & $\begin{array}{l}0.770 \\
0.000\end{array}$ & $\begin{array}{c}-0.561 \\
0.010\end{array}$ & $\begin{array}{l}-0.500 \\
0.034\end{array}$ \\
\hline Casein & $\begin{array}{l}0.781 \\
0.000\end{array}$ & $\begin{array}{l}0.741 \\
0.007\end{array}$ & $\begin{array}{l}0.808 \\
0.000\end{array}$ & $\begin{array}{l}0.857 \\
0.000\end{array}$ & $\begin{array}{c}-0.693 \\
0.000\end{array}$ & $\begin{array}{r}-0.611 \\
0.000\end{array}$ \\
\hline $\mathrm{CPt}$ & $\begin{array}{l}0.611 \\
0.004\end{array}$ & $\begin{array}{l}0.734 \\
0.003\end{array}$ & $\begin{array}{l}0.782 \\
0.000\end{array}$ & $\begin{array}{l}0.736 \\
0.000\end{array}$ & $\begin{array}{c}-0.757 \\
0.000\end{array}$ & $\begin{array}{r}-0.628 \\
0.005\end{array}$ \\
\hline $\mathbf{C P}$ & $\begin{array}{l}0.735 \\
0.000\end{array}$ & $\begin{array}{l}0.742 \\
0.000\end{array}$ & $\begin{array}{l}0.825 \\
0.000\end{array}$ & $\begin{array}{l}0.830 \\
0.000\end{array}$ & $\begin{array}{l}-0.745 \\
0.000\end{array}$ & $\begin{array}{l}-0.634 \\
0.005\end{array}$ \\
\hline Fat & $\begin{array}{r}-0.269 \\
0.265\end{array}$ & $\begin{array}{c}-0.030 \\
0.903\end{array}$ & $\begin{array}{l}0.027 \\
0.912\end{array}$ & $\begin{array}{c}-0.194 \\
0.426\end{array}$ & $\begin{array}{r}-0.035 \\
0.886\end{array}$ & $\begin{array}{r}-0.103 \\
0.695\end{array}$ \\
\hline Total Solids & $\begin{array}{c}-0.059 \\
0.811\end{array}$ & $\begin{array}{l}0.249 \\
0.305\end{array}$ & $\begin{array}{l}0.293 \\
0.223\end{array}$ & $\begin{array}{l}0.072 \\
0.771\end{array}$ & $\begin{array}{c}-0.285 \\
0.238\end{array}$ & $\begin{array}{c}-0.364 \\
0.049\end{array}$ \\
\hline Total Ca & $\begin{array}{l}0.605 \\
0.005\end{array}$ & $\begin{array}{l}0.188 \\
0.427\end{array}$ & $\begin{array}{l}0.276 \\
0.239\end{array}$ & $\begin{array}{l}0.494 \\
0.027\end{array}$ & $\begin{array}{l}-0.151 \\
0.525\end{array}$ & $\begin{array}{r}-0.122 \\
0.629\end{array}$ \\
\hline $\begin{array}{l}\text { Somatic } \\
\text { cells/ } \mu \mathrm{L}\end{array}$ & $\begin{array}{l}0.196 \\
0.408\end{array}$ & $\begin{array}{l}0.075 \\
0.753\end{array}$ & $\begin{array}{l}0.101 \\
0.671\end{array}$ & $\begin{array}{l}0.100 \\
0.578\end{array}$ & $\begin{array}{l}-0.129 \\
0.587\end{array}$ & $\begin{array}{l}-0.282 \\
0.258\end{array}$ \\
\hline pH & $\begin{array}{c}-0.214 \\
0.364\end{array}$ & $\begin{array}{c}-0.099 \\
0.677\end{array}$ & $\begin{array}{c}-0.083 \\
0.728\end{array}$ & $\begin{array}{c}-0.165 \\
0.490\end{array}$ & $\begin{array}{c}-0.016 \\
0.948\end{array}$ & $\begin{array}{c}-0.059 \\
0.816\end{array}$ \\
\hline
\end{tabular}

Cell content: Pearson correlation coefficient (r) on top and $p-v a l u e$ on the bottom. The yellow markings indicate significant correlation

Milk total solids were found to have a weak negative correlation with loss in shredder

(Table 18). Milk pH, fat, non-casein nitrogen, and somatic cells appeared to have no association with the textural aspects of cheese. 
Therefore, during the manufacture of cheese, the calcium, total protein, and casein content in cheese milk should be monitored closely as they are found to have a significant association with the texture and composition of LMPS mozzarella. But as the milk is only a representation and not the exact milk from which the weekly cheese was made, the conclusions that can be drawn from the study were limited.

\section{The Effect of Temperature on Ripening}

The ripening temperature influences the rate of proteolysis, the cheese composition, cheese texture, and micro flora. Most of the studies have concentrated on cheddar and Dutch varieties (Creamer, 1976; Kindstedt et al., 2004). In low moisture mozzarella, Feeney et al. observed that after 15 days of ripening, there was significant difference in $\mathrm{pH}$ 4.6 WSN between cheeses ripened at $10^{\circ} \mathrm{C}$ and $15^{\circ} \mathrm{C}$ and cheese ripened at $0^{0} \mathrm{C}$ and $4^{0} \mathrm{C}$. Also extensive degradation of $\alpha_{\mathrm{s} 1}$-casein was observed at $10^{0} \mathrm{C}$ and $15^{0} \mathrm{C}$. The study indicated that changing the ripening temperature provides a convenient means of controlling proteolysis without altering the type of proteolysis. A lot of researchers have reported that they saw a significant difference in proteolysis when cheeses were ripened above $10^{\circ} \mathrm{C}$, or if the cheese was ripened for more than 50 days at temperatures below $10^{0} \mathrm{C}$ (Jana \& Mandal, 2011).

A brief ripening period of LMPS mozzarella (usually less than a month) is required for the cheese to get the desired functional properties to be used as a pizza ingredient When cheese is maintained at cold temperatures for about two to three weeks, the caseins become more hydrated and swollen due to free water being absorbed back into the protein matrix, and the cheese protein matrix expands into the fat-serum channel giving the cheese the desired meltabilty and oiling off properties (Kindstedt et al., 2004). Newly 
manufactured cheese has excessive moisture at the surface and within the body of cheese, hence it will not shred well. Four to five days of ageing will allow the cheese to absorb the moisture back, and this will improve the shredding quality (McMahon \& Oberg, 2011). Thus, the cheese is shredded typically two to three weeks after manufacture. Therefore, in this study the main focus was to see if there was an association between temperature (below $10^{\circ} \mathrm{C}$ ) and the LMPS mozzarella unheated textural properties, $\mathrm{pH}$, and water soluble nitrogen when ripened for a short period of time (21 days). Thereby, two blocks of $10 \mathrm{lb}$ vacuum packed cheese samples shipped from the plant in Central Valley, California, were subjected to ripening, one block at $3.3^{0} \mathrm{C}$ and the other at $8.9^{0} \mathrm{C}$ for 21 days from the date of manufacture. After 21 days, both the cheese blocks ripened at different temperatures were brought to a core temperature of $3.3^{0} \mathrm{C}$ before carrying out the analysis. The results are summarized in Table 19. 
Table 19. Statistical analysis of fresh and ripened cheese

\begin{tabular}{|c|c|c|c|c|c|c|c|}
\hline $\begin{array}{l}\text { Cheese } \\
\text { paramet } \\
\text { ers }\end{array}$ & Age & $\overline{\mathbf{N}}$ & Mean & SD & Min. & Max. & $\begin{array}{l}* \mathrm{t}- \\
\text { value } \\
\text { p-value }\end{array}$ \\
\hline \multirow[t]{3}{*}{$\mathbf{H}(\mathrm{g})$} & 5 days & 33 & 4135 & 624 & 3088 & 5502 & \multirow[b]{3}{*}{$\begin{array}{c}5.73 \\
0.000\end{array}$} \\
\hline & 21 days $/ 3.3^{0} \mathrm{C}$ & 33 & 3760.1 & 545.5 & 2593.8 & 4820 & \\
\hline & 21 days $/ 8.9^{\circ} \mathrm{C}$ & 33 & 3557 & 598 & 2523 & 4620 & \\
\hline \multirow[t]{3}{*}{$\mathbf{C}$} & 5 days & 33 & 0.51 & 0.04 & 0.42 & 0.66 & \\
\hline & 21 days $/ 3.3^{0} \mathrm{C}$ & 33 & 0.48 & 0.029 & 0.42 & 0.55 & \multirow{2}{*}{$\begin{array}{c}1.60 \\
0.120\end{array}$} \\
\hline & 21 days $/ 8.9^{\circ} \mathrm{C}$ & 33 & 0.48 & 0.029 & 0.421 & 0.53 & \\
\hline \multirow[t]{3}{*}{ Sp } & 5 days & 33 & 0.67 & 0.0488 & 0.58 & 0.75 & \multirow{3}{*}{$\begin{array}{c}0.72 \\
0.475\end{array}$} \\
\hline & 21 days $/ 3.3^{0} \mathrm{C}$ & 33 & 0.63 & 0.04 & 0.56 & 0.70 & \\
\hline & 21 days $/ 8.9^{\circ} \mathrm{C}$ & 33 & 0.63 & 0.04 & 0.54 & 0.69 & \\
\hline \multirow[t]{3}{*}{ Ch (g) } & 5 days & 33 & 1445.5 & 344.4 & 852.4 & 2229.5 & \multirow{3}{*}{$\begin{array}{c}7.34 \\
0.000\end{array}$} \\
\hline & 21 days $/ 3.3^{0} \mathrm{C}$ & 33 & 1151.9 & 257.4 & 735.3 & 1677 & \\
\hline & 21 days $/ 8.9^{\circ} \mathrm{C}$ & 33 & 1068.3 & 246.2 & 663.3 & 1563.6 & \\
\hline \multirow{3}{*}{$\begin{array}{l}\text { Loss in } \\
\text { shredder } \\
(\%)\end{array}$} & 5 days & 33 & 9.71 & 1.40 & 7.30 & 12.76 & \multirow{3}{*}{$\begin{array}{l}-2.86 \\
0.008\end{array}$} \\
\hline & 21 days $/ 3.3^{0} \mathrm{C}$ & 32 & 12.66 & 2.13 & 9.52 & 16.74 & \\
\hline & 21 days $/ 8.9^{0} \mathrm{C}$ & 31 & 14.19 & 2.24 & 10.53 & 18.97 & \\
\hline \multirow[t]{3}{*}{ AGI } & 5 days & 33 & 6.04 & 0.22 & 5.49 & 6.38 & \multirow{3}{*}{$\begin{array}{l}-2.77 \\
0.009\end{array}$} \\
\hline & 21 days $/ 3.3^{0} \mathrm{C}$ & 32 & 6.14 & 0.17 & 5.81 & 6.39 & \\
\hline & 21 days $/ 8.9^{\circ} \mathrm{C}$ & 32 & 6.18 & 0.16 & 5.81 & 6.45 & \\
\hline \multirow[t]{3}{*}{ WSN (\%) } & 5 days & 33 & 0.32 & 0.0401 & 0.27 & 0.45 & \multirow{3}{*}{$\begin{array}{l}-7.60 \\
0.008\end{array}$} \\
\hline & 21 days $/ 3.3^{0} \mathrm{C}$ & 30 & 0.38 & 0.0352 & 0.31 & 0.45 & \\
\hline & 21 days $/ 8.9^{\circ} \mathrm{C}$ & 29 & 0.41 & 0.038 & 0.34 & 0.498 & \\
\hline \multirow[t]{3}{*}{ pH } & 5 days & 33 & 5.47 & 0.0381 & 5.41 & 5.53 & \multirow[b]{2}{*}{0.380} \\
\hline & 21 days $/ 3.3^{0} \mathrm{C}$ & 33 & 5.53 & 0.053 & 5.44 & 5.66 & \\
\hline & 21 days $/ 8.9^{\circ} \mathrm{C}$ & 30 & 5.52 & 0.044 & 5.43 & 5.60 & 0.708 \\
\hline
\end{tabular}

\footnotetext{
*- the $t$-value and p-value were from the paired t test done only for the cheese ripened at $3.3^{\circ} \mathrm{C}$ and $8.9^{\circ}$ $C$ for 21 days. The t-value is above and p-value is below in that column. In the table $\mathrm{N}$-Sample size, $\mathrm{H}$ Hardness, C-Cohesiveness, Sp-Springiness, Ch-Chewiness, AGI-Aggregation Index, WSN-Water soluble nitrogen
}

The mean hardness, cohesiveness, springiness, chewiness decreased, and the average percentage loss in shredder, aggregation index, WSN, and $\mathrm{pH}$ increased after 21 days of 
manufacture in comparison to the five day old cheese. Yun et al. (1993c) reported a decrease in textural characteristics namely hardness, cohesiveness, and springiness when cheese was ripened for 50 days at $4^{0} \mathrm{C}$. As LMPS mozzarella ripened, Jana \& Mandal (2011) reported that there was a significant decrease in the concentration of intact casein and firmness. Kindstedt et al. (1994) observed that for low moisture mozzarella the water soluble nitrogen increased significantly during seven weeks of ripening, but the rate of increase depended on the different coagulants. The increase in water soluble nitrogen can cause an increase in $\mathrm{pH}$ (Jana \& Mandal, 2011). Hence, the decrease in intact casein during proteolysis would be the contributing factor for a decrease in hardness, cohesiveness, springiness, chewiness, and an increase in WSN and pH during the 21-day ripening period. In commercial shredders, where centrifugal force is used for shredding, a firm textured cheese has less deformation, and blades are able to make cleaner cut. In addition, a firm textured cheese cube maintains a uniform speed, and blades can cut shreds the length of the cube. On the other hand, a soft textured cheese bends and deforms around the blade, slowing the portion of the cheese cube in contact with the blade (Rankin et al., 2006). Hence, the decrease in firmness would have attributed to the increase in percentage loss of shredder. There was an increase in aggregation index, which indicates that the shredded cheese clumped and aggregated more in the 21-day ripened cheese than the 5-day old cheese. However, the increase in aggregation index (AGI) was very minimal (approximately $2 \%$ ), and this could be overcome by application of anti-caking agents (Jana \& Mandal, 2011). 
From Table 19 the average hardness, cohesiveness, springiness and chewiness were greater in cheese ripened at $3.3^{0} \mathrm{C}$ than the cheese ripened at $8.9^{\circ} \mathrm{C}$. The mean loss in shredder, AGI, and water soluble nitrogen was less in cheese ripened at $3 \cdot 3^{\circ} \mathrm{C}$. The mean aggregation index (AGI) and $\mathrm{pH}$ were similar in cheese ripened at different temperatures. Paired t- test analyses were done using Minitab Version 17.0 to analyze whether there was any significant difference (at $\alpha=0.05)$ between the hardness, cohesiveness, springiness, chewiness, aggregation index, percentage loss in shredder, $\mathrm{pH}$, and WSN. The data was independent and the $p$-values were all greater than 0.05 in the normality plots indicating that the data was normally distributed (Appendix 8). There was a significant difference in the water soluble nitrogen (WSN), hardness, chewiness, aggregation index, and percent loss in shredder with a $p$-value $<0.05$ when ripened at different temperatures $\left(3.3^{0} \mathrm{C}\right.$ and $\left.8.9^{\circ} \mathrm{C}\right)$ (Table 19). At 95\% confidence limit there was no significant difference in the $\mathrm{pH}$, cohesiveness, and springiness of cheese. 


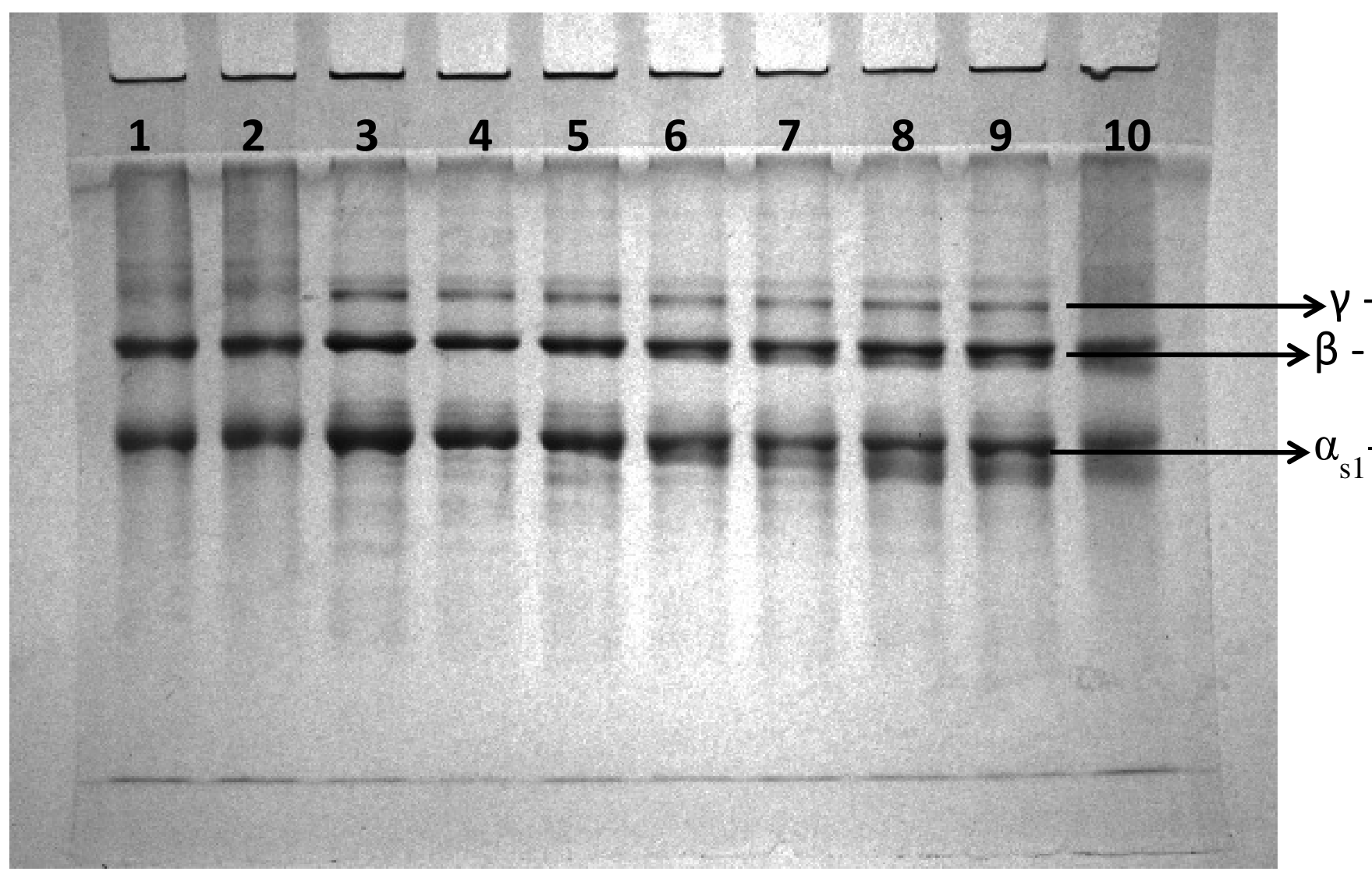

Figure 38. Urea- PAGE of sodium caseinate and LMPS mozzarella ripened at different temperatures. Lane $1 \& 2$ - Sodium caseinate standard. Lane 3, 4, and 5 Fresh cheese. Lane 6 and 7 - Cheese Ripened at $3.3^{\circ}$ C. Lane 8 and 9 - Cheese ripened at $8.9^{0} \mathrm{C}$

Urea-polyacrylamide gel electrophoretogram of the fresh and cheese ripened at different temperatures are shown in. Overall, the trends observed with PAGE are consistent with those of water soluble nitrogen $(p$-value $<0.05$ (Table 19)), which showed that proteolysis was significantly affected by ripening temperature. Increasing the ripening temperature resulted in an increase in the rate of degradation of $\alpha_{\mathrm{s} 1}$-casein where most of the degradation was observed at $8.9^{0} \mathrm{C}$. In agreement with previous studies on Mozzarella (Yun et al., 1993a; Yun et al., 1993b; Fox P.F., 1989), there was very little hydrolysis of $\beta$-casein over the 21 - day period. The relatively low degree of age-related degradation of $\beta$-casein, compared to as $\alpha_{\mathrm{s} 1}$-casein, has also been observed for other cheese varieties 
such as Cheddar, Gouda, and Blue-cheese (Creamer, 1976). Hence, in this study we can conclude that there was an increase in the rate of proteolysis at $8.9^{0} \mathrm{C}$ than at $3.3^{0} \mathrm{C}$. This rate of proteolysis affected the water soluble nitrogen and the textural properties mainly hardness, chewiness, aggregation index, and percentage loss during shredding of LMPS Mozzarella 


\section{CONCLUSIONS}

In this study, seasonal observations for total nitrogen, casein nitrogen, non-protein nitrogen, true nitrogen, casein to total nitrogen ratio, casein to true nitrogen ratio, and total calcium were measured and analyzed in the silo milk collected from a plant in Central Valley, California, from July 2008 to December 2009. The seasonal changes showed that all the above constituents had highest values during winter months and low ones in summer months. In addition, 2008 and 2009 had very less precipitation (Appendix 4), and the hottest months were in June to September with temperatures crossing over $100^{\circ} \mathrm{F}$ (Appendix 3). Hence, the variation of total nitrogen, casein nitrogen, non-protein nitrogen and total calcium can be attributed to the high temperatures (above $100^{0} \mathrm{~F}$ ), less food intake due to heat stress, and longer photoperiods during the summer months compared to the winter months.

Therefore, the accuracy of fixed casein to total protein ratio often used in dairy plants to estimate casein content of milk throughout different seasons is questionable. Thus, it may be concluded that estimating casein from true protein or casein from total protein while accounting for monthly variations of total nitrogen and non-protein nitrogen should be more accurate. As there was a seasonal variation for casein and total calcium, a close monitor of these components may be beneficial to improve the quality and consistency of cheese throughout the year.

The total nitrogen and $\mathrm{pH}$ of low moisture part skim (LMPS) mozzarella was found to have higher values in winter months and decrease during summer. The water soluble calcium of the LMPS mozzarella was found to be less in winter months than summer months. As the $\mathrm{pH}$ of cheese was found to decrease, the water soluble calcium levels increased and vice versa. The hardness, chewiness and springiness of cheese were found 
to have high values in winter and low ones in summer. The loss during shredding and aggregation of LMPS Mozzarella were more in summer than winter months.

The total nitrogen, total calcium, and water soluble calcium of the cheese were found to have significant correlation with the hardness, chewiness, aggregation index and loss in the shredder. Also, the total calcium, total protein, casein, and non-protein nitrogen content in cheese milk were found to have a significant association on the texture and composition of LMPS mozzarella. As the total nitrogen content, true nitrogen, casein, non-protein content, and total calcium of milk varied by $0.06 \%, 0.066 \% 0.53 \%, 0.019 \%$, and $0.03 \%$ respectively (Table 9 ), there was a variation of $0.45 \%$ of total nitrogen, $0.13 \%$ total calcium $0.088 \%$ water soluble calcium, (Table 12), $2414 \mathrm{~g}$ of hardness, $5.45 \%$ loss in shredder, and 0.90 of AGI (Table 14) in LMPS Mozzarella between seasons. The pH of the cheese did not significantly correlate with the textural characteristics of the cheese. However, as $\mathrm{pH}$ of cheese had a moderate negative with water soluble calcium and loss in shredder correlated positively with the water soluble calcium. $\mathrm{pH}$ of cheese was increased to above 5.45 during summer months to prevent the water soluble calcium levels from increasing, and hence the loss in shredder was minimized. The total nitrogen content of cheese during the summer months was also increased by changing the manufacturing protocol. Hence, the firmness of cheese was increased, and the aggregation index and percentage losses in shredder were minimized during the summer months.

Therefore, higher total nitrogen content, mainly the casein content and total calcium of milk, brought about higher total nitrogen content of LMPS Mozzarella and firmer cheese, which in turn contributed to less loss in shredder and less aggregation in LMPS 
Mozzarella. Since the milk samples were only a representation and not the exact milk from which the cheese was made, the conclusions that can be drawn from this study are limited.

Also, there was a significant difference $(\alpha=0.05)$ in the water soluble nitrogen (WSN), hardness, chewiness, aggregation index, and percent loss in shredder with a $p$-value $<$ 0.05 when LMPS Mozzarella was ripened at different temperatures $\left(3.3^{0} \mathrm{C}\right.$ and $\left.8.9^{0} \mathrm{C}\right)$ for 21 days (Table 19). At 95\% confidence limit, there was no significant difference in the $\mathrm{pH}$, cohesiveness, and springiness of cheese when the cheese was ripened at different temperatures. Increasing the ripening temperature resulted in an increase in the rate of degradation of $\alpha_{s 1}$-casein where most of the degradation was observed at $8.9^{0} \mathrm{C}$. There was relatively low degree of age-related degradation of $\beta$-casein, compared to as $\alpha_{\mathrm{s} 1}-$ casein. Hence, in this study we can conclude that there was an increase in the rate of proteolysis at $8.9^{0} \mathrm{C}$ than at $3.3^{0} \mathrm{C}$. This rate of proteolysis affected water soluble nitrogen content of cheese and the textural properties of LMPS Mozzarella mainly the hardness, chewiness, aggregation index, and percentage loss during shredding. 


\section{RECOMMENDATIONS FOR FUTURE WORK}

- In this study, the seasonal variation of milk components was analyzed by collecting milk samples from only one plant in the Central valley, California. To eliminate limitations', milk samples should be taken from different plants and different areas in California to give us more information on the seasonal variation of milk composition.

- Also, the milk used for making cheese should be analyzed to study the association of milk composition on cheese composition and texture. In this study the milk from silo was only a representation and not the exact milk from which the cheese was made, hence the conclusions that can be drawn from the study were limited.

- As this was an observational study, no cause and effect conclusions can be drawn. Hence a well-designed experimental study would give more substantial conclusions 


\section{REFERENCES}

AOAC (1995) Official Methods of Analysis. Dairy Products. 16th ed. Association of Official Analytical Chemists. Arlington, VA. pp: 11-13.

AOAC (2000) Official Methods of Analysis. Dairy Products 17th ed. Association of Official Analytical Chemists. Arlington, VA. pp: 1- 57.

Arnold R.M., (2008a). Lab Procedures Compiled by Arnold - Analysis of Salt in Cheese, Samples Dairy Products Technology Center, California Polytechnic State University, San Luis Obispo, CA.

Arnold R.M., (2008b). Lab Procedures Compiled by Arnold - Texture Profile Analysis of Cheese Samples. Dairy Products Technology Center, California Polytechnic State University, San Luis Obispo, CA.

Arnold R.M., (2008c). Lab Procedures Compiled by Arnold - UREA Page for Cheese Samples Dairy Products Technology Center, California Polytechnic State University, San Luis Obispo, CA.

Banks, J.M., (2007) How is Cheese Yield Defined? In: Cheese Problems Solved edited by McSweeney, P.L.H., CRC press, Boca Raton, FL, USA. pp $102-105$. Retrieved from http://books.google.com/books?id=gKijAgAAQBAJ\&pg= PA107\&lpg=PA107\&dq\#v=onepage \&q\&f=false May 2014

Banville, V., Morin, P., Pouliot, Y., and Britten, M., (2013) Physical Properties of Pizza Mozzarella Cheese Manufactured under Different Cheese Making Conditions. J. Dairy Sci. 96: 4804-4815.

Barbano D.M., (1987) Impact of Seasonal Variation in Milk Composition on Cheese Yields and Composition. Dairy Field October: 46 - 50. 
Barbano, D., and Wojciechowski, K., (2012) Issues Related to Sampling and Analysis of Milk. Tri-State Dairy Nutrition Conference, 33-41.

Barbano, D.M., (1994) Reference and Routine Methods for Measurement of Nitrogen Fractions. In Protein Definition. International Dairy Federation Publication S.1.19403, Brussels, Belgium, pp 50 -54.

Barbano, D.M., Verdi, R., and Rasmusse, R., (1987a). Milk Quality Influences Cheese Yields. Dairy Field November: 22-25.

Bernabucci, U., Lacetera, N., Ronchi, B., and Nardone A., (2002) Effects of the Hot Season on Milk Protein Fractions in Holstein Cows. Anim. Res. 51: 25-33.

Bertocchi, L., Vitali, A.,. Lacetera ,N.,. Nardone, A., Varisco, G., and Bernabucci, U., (2014) Seasonal Variations in the Composition of Holstein Cow's Milk and Temperature-Humidity Index Relationship. Animal 8(4): 667-674.

Bruhn, J. C., and Franke, A. A., (1977) Monthly Variations in Gross Composition in California Herd Milks. J. Dairy Sci. 60: 696-700.

Bruhn, J. C., and Franke, A. A., (1991) Raw Milk Composition and Cheese Yields in California: 1987 and 1988. J. Dairy Sci. 74(3): 1108-1114.

Callaghan, D.J.O. and Guinee, T.P., (2004) Rheology and Texture of Cheese. In: Chemistry, Physics and Microbiology (Volume 1) edited by Fox P.F., McSweeney P.L.H, Cogan T.M and Guinee T.P., 3rd edition. Elsevier Academic Press, California, USA. pp: 205 - 259 .

CFR 133.155 to 133.158. Retrieved from http://www.access.gpo.gov/nara/cfr /waisidx_06/21cfr133_06.html from May 2014 
Chen, C.M., (2003) Final report: Development and Application of Cheese Shred/Texture Map Delineated by Cheese Rheological, Sensory and Chemical Analysis.

Wisconsin Center for Dairy Research Annual Report FY 2003.

Childs, J.L., Daubertr, C.R., Stefanski, L., and Foegeding, E.A., (2007) Factors

Regulating Cheese Shreddability. J. Dairy Sci. 90: 2163-2174.

Creamer L.K., (1976) Casein Proteolysis in Mozzarella Type Cheese, N.Z.J. Dairy Sci. Technol. 11: 131-132.

DeLaval Cell Counter DCC Manual. Retrieved from http://www.delaval.com/en/-

/Product-Information1/Milking/Products/Milk-test--treatment/DeLaval-CellCounter-DCC/DCC/ September 2014.

DePeters, E.J., and Ferguson, J.D., (1992) Non-protein Nitrogen and Protein Distribution in the Milk of Cows. J. Dairy Sci. 75: 3192-3209.

Dohoo, I.R., and Meek, A.H., (1982) Somatic Cell Counts in Bovine milk. Can. vet. J. 23: $119-125$.

Feeney, E.P., Foe, P.F., Guinee, T.P., (2001) Effect of Ripening Temperature of the Quality of Low Moisture Mozzarella Cheese: 1. Composition and Proteolysis, Lait 81: 463-474.

Fox P.F. and Cogan T.M., (2004) Factors that Affect Cheese Quality. In: Cheese: Chemistry, Physics and Microbiology (Volume 1) edited by Fox P.F., McSweeney P.L.H, Cogan T.M and Guinee T.P. 3rd edition. Elsevier Academic Press. pp: $583-609$.

Fox P.F., (1989) Proteolysis during Cheese Manufacture and Ripening. J. Dairy Sci. 72: 1389-1410. 
Fox, P.F., and McSweeneyP.L.H. (1998) Dairy Chemistry and Biochemistry. In:

Chemistry and Biochemistry of Cheese and Fermented Milks. Academic and Professional Press, London, UK. pp: $379-424$.

Fox, P.F., and McSweeneyP.L.H., (1998) Dairy Chemistry and Biochemistry. Production and Utilization. Composition and Variability of Milk. Blackie Academic and Professional Press, London, UK. pp: 1-20.

Fox, P.F., Guinee, T.P., Cogan, T.M., andMcSweeney, P.L.H., (2000) Cheese Rheology and Texture. In Fundamentals of Cheese Science. Aspen Publishers, Maryland, USA. pp: $305-340$.

Franke, A. A., Bruhn, J. C., and Lawerence, C.M., (1988) Distribution of Protein in California in 1983. J. of Dairy Sci. 71: 2373-2383.

Frost, J., (2013) How to Interpret Regression Analysis Results: P-values and Coefficients. http://blog.minitab.com/blog/adventures-in-statistics/how-to-interpret-regressionanalysis-results-p-values-and-coefficients. Retrieved on May 2014.

Glantz , M., Lindmark Månsson H.,. Stålhammar, H., Bårström, L.O., Fröjelin, M., Knutsson, A., Telu , C., and Paulsson M., (2009) Effects of Animal Selection on Milk Composition and Processability J. Dairy Sci. 92: 4589-4603. A

Goff, H.D., (2009) Factors Affecting Milk Composition. Retrieved from www.uoguelph.ca/foodscience/ cheese-making-technology/section-c-milk/rawmilk-quality/factors-affecting-gross-milk-composition, May 2014.

Guinee, T. P., Kennedy, B. T. O. and Kelly, P. M., (2006) Effect of Milk Protein Standardization Using Different Methods on the Composition and Yields of Cheddar Cheese. J. Dairy Sci. 89:468-482. 
Guinee, T.P. (2002) The Functionality of Cheese as an Ingredient: A review. Aust. J. Dairy Technol. 57: 79-91.

Guinee, T.P., and Fox, P.F., (2004) Salt in Cheese: Physical, Chemical and Biological Aspects. In: Cheese: Chemistry, Physics and Microbiology (Volume 1) edited by Fox P.F., McSweeney P.L.H, Cogan T.M and Guinee T.P. 3rd edition. Elsevier Academic Press. pp: $207-269$.

Guinee, T.P., Feeney, E.P., Auty M.A.E., and Fox P.F., (2002) Effect of pH and Calcium Concentration on Some Texture Properties of Mozzarella Cheese. J. Dairy Sci. $85,1655-1669$.

Gunasekeran, S. and Ak, M.M. (2000) Cheese Rheology and Texture. CRC Public Press, USA. pp. $308-328$.

Gunasekeran, S. and Ak, M.M. (2000a) Cheese Rheology and Texture. CRC Public Press, USA. pp. $388-405$.

Halmos, A.L., (2000) Relationships Between Instrumental Texture Measurements and Sensory Attributes in Hydrocolloids-Part 2,edited by Nishinari, K., Elseiver Press, Amsterdam. pp: 431-444.

Heck, J. M. L., van Valenberg, H. J. F., Dijkstra, J., and van Hooijdonk, A. C. M., (2009) Seasonal variation in the Dutch Bovine Raw Milk Composition. J. Dairy Sci. 92: $4745-4755$.

Heinrichs, J., Jones, C., and Bailey, K., (2005). Retrieved from http://extension.psu.edu/ animals/dairy/ nutrition/nutrition-and-feeding/diet-formulation-andevaluation/milk-components -understanding-the-causes-and-importance-of-milkfat-and-protein-variation-in-your-dairy-herd May, 2014. 
http://www.ilri.org/InfoServ/Webpub/fulldocs/ilca_manual4/Factors.htm. Data retrieved from this website May 2014

Huppertz, T. and Kelly, A.L., (2009) Properties and Constituents of Cows Milk. In: Milk Processing and Quality Management edited by Tamime A.Y., John Wiley \& Sons., UK. pp: $23-44$.

Jana, A.H. and Mandal, P.K., (2011) Manufacturing and Quality of Mozzarella Cheese: A review. Int. J. Dairy Sci. 6(4):199-226.

Jones G.M., (2011) US Recovery Helps Mozzarella Make-up Lost Ground. Retrieved from http://www. dairyreporter.com/arkets/US-recovery-helps-Mozzarella-makeup-lost-ground. May 2014

Joshi, N.S., Muthukumarappan, K., and Dave, R.I., (2004) Effect of Calcium on Microstructure and Meltability of Part Skim Mozzarella Cheese. J. Dairy Sci. 87, (7): 1975-1985.

Kelly, A.L., (2007b) What are Milk Salts and How Do They Affect the Properties of Cheese? In: Cheese Problems Solved edited by McSweeney, P.L.H., CRC press, Boca Raton, FL. pp: 7-8. Retrieved from http://books.google.com/books?id= gKijAgAAQBAJ\&pg= PA107\&lpg= PA107\&dq\#v=onepage\&q\&f=false, May 2014

Kelly, A.L., (2007a) What is Typical Composition of Cow's Milk and What Milk Constituents Favor Cheesemaking? In: Cheese Problems Solved edited by McSweeney, P.L.H., CRC press, Boca Raton, FL. pp: 3-4. Retrieved from http://books.google.com/books?id= gKijAgAAQBAJ\&pg= PA107\&lpg= PA107\&dq\#v=onepage \&q\&f=false, May 2014 
Kimura, T., Sagara, Y., Fukushima, M., and Taneya, S., (1992) Effect of pH on Submicroscopic Structure of String Cheese. Milchwissenschaft. 47:547-552.

Kindstedt, P. S., M. Rowney, and P. Roupas. (1999) Technology, Biochemistry and Functionality of Pasta Filata/Pizza Cheese. In: Technology of Cheesemaking, Sheffield Press, Shielflied. pp: $193-221$.

Kindstedt, P.S., (1999) Mozzarella and Pizza Cheese. In: Cheese: Chemistry Physics and Microbiology (Volume 2) edited by Fox, P.F., Aspen Publishers, Maryland, USA. pp: 259-271.

Kindstedt, P.S., Caric, M., Milanovic, S., (2004) Pasta-Filata cheese. In: Cheese: Chemistry, Physics and Microbiology (Volume2) edited by Fox P.F., McSweeney P.L.H, Cogan T.M. and Guinee T.P., 3rd edition. Elsevier Academic Press, USA. pp: $251-277$.

Kindstedt, P.S., Guo, M.R., (1997) Recent Developments in the Science and Technology of Pizza Cheese. Review Aust. J. Dairy Technol. 52: 41 -43.

Kuchroo C.N., Fox P.F. (1982). Fractionation of the Water-Soluble-Nitrogen from Cheddar Cheese: Chemical Methods. Milchwissenschaft, 37: 651-653

Laben, R.C., (1963) Factors Responsible for Variation in Milk Composition. J.Dairy Sci. 46, (11) : 1293-1301.

Lacroix, C., Verret, P., and Paquin, P., (1996) Regional and Seasonal variations of Nitrogen fractions in commingled Milk. Int. Dairy Journal 6: 947-961.

Larsen, M. K., Nielsen, J. H., Butler, G., Leifert, C., Slots, T., Kristiansen, G. H., and A. H Gustafsson,A A. H., (2010) Milk Quality as Affected by Feeding Regimens in a Country with Climatic Variation. J. Dairy Sci. 93: 2863-2873. 
Looper, M., Factors Affecting Milk Composition of Lactating Cows. Agriculture and Natural Resources, Divison of Agriculture Research \& Extension, University of Arkansas. Retrieved from http://www.uaex.edu/publications/pdf/fsa-4014.pdf September 2014.

Lucey, J.A., Johnson, M. E., and Horne, D. S., (2003) Invited Review: Perspectives on the Basis of the Rheology and Texture Properties of Cheese. J. Dairy Sci. 86: 2725-2743.

McMahon, D.J., Oberg, C.J. (2011) Pasta-Filata Cheeses: Low-Moisture Part-Skim Mozzarella (Pizza Cheese)Encyclopedia of Dairy Sciences, pp 737-744.

Metzger, L.E., Barbano, D.M., Rudan, M. A. and Kindstedt, P.S., (2000a). Effect of Milk Pre-acidification on Low Fat Mozzarella Cheese: I. Composition and Yield. J. Dairy Sci. 83:648-658.

Metzger, L.E., Barbano, D.M., Rudan, M. A. and Kindstedt, P.S., (2000b). Effect of Milk Pre-acidification on Low Fat Mozzarella Cheese: III. Composition and Yield. J. Dairy Sci. 84:1357-1366.

Neil (2010) N.E.M Business Solutions. Retrieved from http://www.cip.ukcentre .com/cheese.htm. May, 2014.

Nelson James Cholride Analyser M 925 Manual. Taken from the California Polyetechnic State University- Dairy Center Lab.

Nickerson, S.C., (1999) Milk production: Factors Affecting Milk Composition. In: Milk Quality by Frank Harding. Aspen publishers, USA, pp $16-20$.

Nickerson, T.A. (1960). Chemical Composition of Milk. J. Dairy Sci. 43:598-606 
O’Mahony, F., (1998) Rural Dairy Technology, Experience in Ethiopia. Retrieved from http://www.ilri.org/InfoServ/Webpub/fulldocs/ilca_manual4/Factors.htm\#TopOfP age May, 2014.

Ozrenk, E., and Selcuk, S., (2008) The Effect of Seasonal Variation on the Composition of Cow Milk in Van Province. Pakistan J. Nutrition 7 (1): 161-164.

Pavel, E. R., Gavan, C., (2011) Seasonal changes in Bulk Tank Milk Composition of Dairy Cows. Animal Science and Biotechnologies, 44 (2): 444-449.

Peck, R., and Devore, J., (2008) Simple Linear regression and Correlation: Inferential Methods In: Statistics-The Exploration and Analysis of Data. Duxbury, an imprint of Thomson Brooks/Cole.USA. pp 571-580.

Peck, R., and Devore, J., (2008) Summarizing Bivaraite Data - Correlation. In: StatisticsThe Exploration and Analysis of Data. Duxbury, an imprint of Thomson Brooks/Cole.USA. pp 190-201.

R.J. FitzGerald, R.J., Walsh, D., Guinee, T.P., Murphy, J.J., Mehra, R., Harrington D., Connoly, J.F., (2004) Genetic Variants of Milk Proteins and Their Association with Milk Production and Processing Properties. The Dairy Products Research Centre, Morrepark, Cork. pp $1-11$.

Rankin, S.A., Chen, C.M., and Sommer, D., (2006) Mozzarella and Scamorza Chesse. Handbook of Food Science, Technology and Engineering, Volume 4 edited by Hui, Y.H., CRC Press, Taylor and Francis Group, Boca Raton, FL. pp: 150-1 to $150-11$. 
Ratner, B., The Coefficient Correlation: Determination Retrieved from http://www.dmstat1.com/res/TheCorrelationCoefficientDefined.html September 2014.

Schroeder, J.W., (2012) Dairy Cow Nutrition Affects Milk Composition. NDSU Extension Service.

Taneya, S., Izutsu, T., Kimura, T., and Shioya, T., (1991). Structure and Rheology of String Cheese. Food Structure. 11: 61-71.

Tremblay, L., Laporte, F.M., Leonil, J., Dupont, D. and Paquin P. (2003) Quantification of Protein in Milk Products. Fox, P.F. and McSweeney P.L.H. (eds) Advanced dairy chemistry -I. proteins, 3rd Edition, Kluwer Academic Publishers, New York. pp: $49-119$.

TTC Texture technologies website (2009) http://128.121.92.221/texture_profile _analysis.html. Accessed May, 2014.

Verdi, R.J., Barbano, D.M., Dellavalle, M.E., and Senyk, G.F., (1987) Variability in True Protein, Casein, Non-protein Nitrogen, and Proteolysis in High and Low Somatic Cell Milks. J. Dairy Sci. 70: $230-242$.

Walstra, P., Geurts, T.J., Noomen, A., Jellema, A., Van Boekel, M.A.J.S., (1999) Composition, Structure and Properties. In: Dairy Technology: Principles of Milk Properties. CRC Press, Boca Raton, FL. pp: 3 - 27.

Walstra, P., Wouters, J.T.M, and Geurts, T.J., (2006a) Milk: Main Characteristics. In: Dairy Science and Technology 2nd edition CRC Press, Boca Raton, FL. pp 1 13. 
Walstra, P., Wouters, J.T.M, and Geurts, T.J., (2006b) Principles of Cheese making. In: Dairy Science and Technology 2nd edition CRC Press, Boca Raton, FL.pp 571 582.

Walstra, P., Wouters, J.T.M, and Geurts, T.J., (2006c) Proteins. In: Dairy Science and Technology 2nd edition CRC Press, Boca Raton, FL. pp 63 - 83.

Weather data for 2008 and 2009 is taken from www. weathersource.com.. Data retrieved from August $21^{\text {st }} 2014$ to obtain weather report .

Wedholm, A., (2008) Variation in Milk Protein Composition and its Importance for the Quality of Cheese Milk - Doctoral Thesis in Swedish University of Agricultural Sciences, Uppsala. Retrieved from http://pub.epsilon.slu.se/1701/1/ AWKappa.pdf, May 2014

Wehr, H.M. and Frank, J.F. (2004) Standard Methods for the Examination of Dairy Products, 17th ed. American Public Health Association. Washington, D.C. pp: $414-418$.

Wendorff, B., and Paulus. K., (2011) Impact of Breed on the Cheese Making Potential of Milk; Volume vs Content. Dairy Pipeline. 23(1): 1-8

Yun J.J., Barbano D.M., Kindstedt P.S., (1993a). Mozzarella cheese: Impact of milling pH on chemical composition and proteolysis, J. Dairy Sci. 76: 3629-3638.

Yun J.J., Kiely L.J., Barbano D.M., Kindstedt P.S., (1993b). Mozzarella cheese: Impact of cooking temperature on chemical composition, proteolysis and functional properties, J. Dairy Sci. 76: 3664-3673. 
Yun J.J., Kiely L.J., Barbano D.M., Kindstedt P.S., (1993c). Mozzarella cheese: Impact of coagulant type on chemical composition, proteolysis, J. Dairy Sci. 76: 36483654. 


\section{APPENDICES}

\section{Appendix 1. Milk Raw Data}

\begin{tabular}{|c|c|c|c|c|c|c|c|}
\hline Month & $\begin{array}{c}\text { Sample } \\
\text { No. }\end{array}$ & $\begin{array}{c}\text { Number } \\
\text { of week } \\
\text { in a year }\end{array}$ & $\begin{array}{c}\text { Total } \\
\text { Nitrogen } \\
\%\end{array}$ & $\begin{array}{c}\text { True } \\
\text { Nitrog } \\
\text { en } \%\end{array}$ & $\begin{array}{c}\text { Non- } \\
\text { Protein } \\
\text { Nitrogen } \\
\%\end{array}$ & $\begin{array}{c}\text { Casein } \\
\text { Nitrogen } \\
\%\end{array}$ & $\begin{array}{c}\text { Non- } \\
\text { Casein } \\
\text { Nitrogen } \\
\%\end{array}$ \\
\hline \multirow[t]{4}{*}{ Jul-08 } & MO5 & 27 & 0.5017 & 0.4794 & 0.0223 & 0.3796 & 0.1221 \\
\hline & MO6 & 28 & 0.4921 & 0.4707 & 0.0214 & 0.3884 & 0.1037 \\
\hline & MO7 & 29 & 0.4982 & 0.4767 & 0.0214 & 0.3962 & 0.1020 \\
\hline & MO8 & 30 & 0.4920 & 0.4706 & 0.0213 & 0.3881 & 0.1038 \\
\hline \multirow[t]{4}{*}{ Aug-08 } & MO9 & 31 & 0.4981 & 0.4777 & 0.0204 & 0.3913 & 0.1068 \\
\hline & MO10 & 32 & 0.4983 & 0.4780 & 0.0203 & 0.3902 & 0.1081 \\
\hline & MO11 & 33 & 0.5032 & 0.4821 & 0.0211 & 0.4068 & 0.0964 \\
\hline & MO12 & 34 & 0.5209 & 0.4970 & 0.0239 & 0.4180 & 0.1029 \\
\hline \multirow[t]{8}{*}{ Sep-08 } & MO13 & 35 & 0.5071 & 0.4828 & 0.0243 & 0.4152 & 0.0920 \\
\hline & MO14 & 36 & 0.5137 & 0.4922 & 0.0215 & 0.4154 & 0.0983 \\
\hline & MO15 & 37 & 0.5050 & 0.4814 & 0.0236 & 0.4093 & 0.0957 \\
\hline & MO16 & 38 & 0.5056 & 0.4824 & 0.0232 & 0.4068 & 0.0988 \\
\hline & MO17 & 39 & 0.5154 & 0.4926 & 0.0228 & 0.4045 & 0.1108 \\
\hline & MO18 & 40 & 0.5022 & 0.4802 & 0.0220 & 0.4052 & 0.0970 \\
\hline & MO19 & 41 & 0.5083 & 0.4886 & 0.0197 & 0.4142 & 0.0940 \\
\hline & MO20 & 42 & 0.5312 & 0.5053 & 0.0259 & 0.4402 & 0.0910 \\
\hline \multirow[t]{6}{*}{ Nov-08 } & MO21 & 43 & 0.5264 & 0.5004 & 0.0260 & 0.4364 & 0.0900 \\
\hline & MO22 & 44 & 0.5275 & 0.4969 & 0.0305 & 0.4366 & 0.0909 \\
\hline & MO23 & 45 & 0.5335 & 0.5019 & 0.0316 & 0.4302 & 0.1267 \\
\hline & MO24 & 46 & 0.5354 & 0.5041 & 0.0313 & 0.4372 & 0.1248 \\
\hline & MO25 & 47 & 0.5375 & 0.5061 & 0.0314 & 0.4302 & 0.1280 \\
\hline & MO26 & 48 & 0.5393 & 0.5071 & 0.0323 & 0.4447 & 0.1140 \\
\hline \multirow[t]{4}{*}{ Dec-08 } & MO27 & 49 & 0.5435 & 0.5115 & 0.0320 & 0.4441 & 0.1144 \\
\hline & MO28 & 50 & 0.5402 & 0.5069 & 0.0333 & 0.4465 & 0.1037 \\
\hline & MO29 & 51 & 0.5423 & 0.5105 & 0.0318 & 0.4438 & 0.1132 \\
\hline & MO30 & 52 & 0.5424 & 0.5078 & 0.0346 & 0.4443 & 0.1201 \\
\hline \multirow[t]{4}{*}{ Jan-09 } & MO31 & 1 & 0.5441 & 0.5136 & 0.0305 & 0.4418 & 0.1023 \\
\hline & MO32 & 2 & 0.5405 & 0.5117 & 0.0287 & 0.4392 & 0.1079 \\
\hline & MO33 & 3 & 0.5454 & 0.5142 & 0.0312 & 0.4441 & 0.1153 \\
\hline & MO34 & 4 & 0.5247 & 0.4950 & 0.0297 & 0.4241 & 0.1002 \\
\hline \multirow[t]{3}{*}{ Feb-09 } & MO35 & 5 & 0.5182 & 0.4870 & 0.0312 & 0.4185 & 0.0997 \\
\hline & MO36 & 6 & 0.5258 & 0.4964 & 0.0294 & 0.4295 & 0.0963 \\
\hline & MO37 & 7 & 0.4853 & 0.4603 & 0.0250 & 0.3719 & 0.1134 \\
\hline
\end{tabular}




\begin{tabular}{|c|c|c|c|c|c|c|c|}
\hline Month & $\begin{array}{c}\text { Sample } \\
\text { No. }\end{array}$ & $\begin{array}{c}\text { Number } \\
\text { of week } \\
\text { in a year }\end{array}$ & $\begin{array}{c}\text { Total } \\
\text { Nitrogen } \\
\%\end{array}$ & $\begin{array}{c}\text { True } \\
\text { Nitrogen } \\
\%\end{array}$ & $\begin{array}{c}\text { Non- } \\
\text { Protein } \\
\text { Nitrogen } \\
\%\end{array}$ & $\begin{array}{c}\text { Casein } \\
\text { Nitrogen } \\
\%\end{array}$ & $\begin{array}{c}\text { Non - } \\
\text { Casein } \\
\text { Nitrogen } \\
\%\end{array}$ \\
\hline & MO38 & 8 & 0.4767 & 0.4526 & 0.0241 & 0.3637 & 0.1130 \\
\hline \multirow[t]{4}{*}{ Mar-09 } & MO39 & 9 & 0.5061 & 0.4772 & 0.0289 & 0.3970 & 0.1091 \\
\hline & MO40 & 10 & 0.5100 & 0.4859 & 0.0241 & 0.4009 & 0.1091 \\
\hline & MO41 & 11 & 0.5003 & 0.4759 & 0.0243 & 0.4068 & 0.0934 \\
\hline & MO42 & 12 & 0.4882 & 0.4654 & 0.0228 & 0.3938 & 0.0944 \\
\hline \multirow[t]{4}{*}{ Apr-09 } & MO43 & 13 & 0.5147 & 0.4907 & 0.0240 & 0.4105 & 0.1041 \\
\hline & MO44 & 14 & 0.5089 & 0.4847 & 0.0242 & 0.3927 & 0.1162 \\
\hline & MO45 & 15 & 0.5092 & 0.4844 & 0.0248 & 0.3948 & 0.1144 \\
\hline & MO46 & 16 & 0.5087 & 0.4867 & 0.0220 & 0.3937 & 0.1150 \\
\hline \multirow[t]{4}{*}{ Мay-09 } & MO47 & 17 & 0.5034 & 0.4795 & 0.0239 & 0.3870 & 0.1163 \\
\hline & MO48 & 18 & 0.5074 & 0.4826 & 0.0248 & 0.3932 & 0.1142 \\
\hline & MO49 & 19 & 0.4995 & 0.4743 & 0.0252 & 0.3868 & 0.1127 \\
\hline & MO50 & 20 & 0.5030 & 0.4768 & 0.0262 & 0.3940 & 0.1090 \\
\hline \multirow[t]{6}{*}{ Jun-09 } & MO51 & 21 & 0.5021 & 0.4786 & 0.0235 & 0.3906 & 0.1115 \\
\hline & MO52 & 22 & 0.4876 & 0.4620 & 0.0256 & 0.3790 & 0.1086 \\
\hline & MO53 & 23 & 0.4850 & 0.4598 & 0.0252 & 0.3825 & 0.1025 \\
\hline & MO54 & 24 & 0.5087 & 0.4832 & 0.0255 & 0.3940 & 0.1147 \\
\hline & MO55 & 25 & 0.5158 & 0.4892 & 0.0267 & 0.4038 & 0.1120 \\
\hline & MO56 & 26 & 0.5068 & 0.4793 & 0.0275 & 0.3996 & 0.1072 \\
\hline \multirow[t]{4}{*}{ Jul-09 } & MO57 & 27 & 0.5015 & 0.4768 & 0.0247 & 0.3999 & 0.1016 \\
\hline & MO58 & 28 & 0.4959 & 0.4719 & 0.0240 & 0.3915 & 0.1045 \\
\hline & MO59 & 29 & 0.4947 & 0.4730 & 0.0216 & 0.3893 & 0.1053 \\
\hline & MO60 & 30 & 0.5041 & 0.4839 & 0.0201 & 0.4027 & 0.1014 \\
\hline \multirow[t]{4}{*}{ Aug-09 } & MO61 & 31 & 0.5142 & 0.4875 & 0.0267 & 0.4083 & 0.1060 \\
\hline & MO62 & 32 & 0.5009 & 0.4802 & 0.0208 & 0.3929 & 0.1080 \\
\hline & MO63 & 33 & 0.5025 & 0.4810 & 0.0215 & 0.4067 & 0.0958 \\
\hline & MO64 & 34 & 0.5025 & 0.4861 & 0.0164 & 0.4050 & 0.0975 \\
\hline \multirow[t]{4}{*}{ Sep-09 } & MO65 & 35 & 0.5063 & 0.4884 & 0.0178 & 0.4060 & 0.1003 \\
\hline & MO66 & 36 & 0.5066 & 0.4849 & 0.0217 & 0.4089 & 0.0977 \\
\hline & MO67 & 37 & 0.5196 & 0.4991 & 0.0205 & 0.4064 & 0.1132 \\
\hline & MO68 & 38 & 0.5298 & 0.5086 & 0.0212 & 0.4197 & 0.1101 \\
\hline \multirow[t]{6}{*}{ Oct-09 } & MO69 & 39 & 0.5227 & 0.5007 & 0.0220 & 0.4125 & 0.1102 \\
\hline & MO70 & 40 & 0.5243 & 0.5023 & 0.0220 & 0.4167 & 0.1076 \\
\hline & MO71 & 41 & na & na & na & na & na \\
\hline & MO72 & 42 & na & na & na & na & na \\
\hline & MO73 & 43 & 0.5211 & 0.4969 & 0.0242 & 0.4110 & 0.1101 \\
\hline & MO74 & 44 & 0.5235 & 0.5014 & 0.0221 & 0.4225 & 0.1010 \\
\hline Nov -09 & MO75 & 45 & 0.5376 & 0.5193 & 0.0183 & 0.4355 & 0.1021 \\
\hline
\end{tabular}




\begin{tabular}{|c|c|c|c|c|c|c|c|}
\hline Month & $\begin{array}{c}\text { Sample } \\
\text { No. }\end{array}$ & $\begin{array}{c}\text { Number } \\
\text { of week } \\
\text { in a } \\
\text { year }\end{array}$ & $\begin{array}{c}\text { Total } \\
\text { Nitrogen } \\
\mathbf{\%}\end{array}$ & $\begin{array}{c}\text { True } \\
\text { Nitrogen } \\
\mathbf{\%}\end{array}$ & $\begin{array}{c}\text { Non- } \\
\text { Protein } \\
\text { Nitrogen } \\
\mathbf{\%}\end{array}$ & $\begin{array}{c}\text { Casein } \\
\text { Nitrogen } \\
\text { \% }\end{array}$ & $\begin{array}{c}\text { Non- } \\
\text { Casein } \\
\text { Nitrogen } \\
\text { \% }\end{array}$ \\
\hline & MO76 & 46 & 0.5345 & 0.5144 & 0.0201 & 0.4303 & 0.1042 \\
\hline & MO77 & 47 & 0.5365 & 0.5044 & 0.0321 & 0.4352 & 0.1013 \\
\hline & MO78 & 48 & 0.5371 & 0.5039 & 0.0332 & 0.4370 & 0.1001 \\
\hline Dec-09 & MO79 & 49 & 0.5323 & 0.5036 & 0.0287 & 0.4342 & 0.0981 \\
\hline & MO80 & 50 & 0.5321 & 0.5087 & 0.0234 & 0.4401 & 0.0920 \\
\hline & MO81 & 51 & 0.5381 & 0.5083 & 0.0298 & 0.4458 & 0.0923 \\
\hline & MO82 & 52 & 0.5398 & 0.5127 & 0.0271 & 0.4397 & 0.1001 \\
\hline
\end{tabular}




\begin{tabular}{|c|c|c|c|c|c|}
\hline Month & $\begin{array}{c}\text { Sample } \\
\text { No. }\end{array}$ & $\begin{array}{c}\text { Number } \\
\text { of week } \\
\text { in a year }\end{array}$ & $\begin{array}{l}\text { Casein/ Total } \\
\text { Nitrogen }\end{array}$ & $\begin{array}{l}\text { Casein/True } \\
\text { Nitrogen }\end{array}$ & Fat $\%$ \\
\hline \multirow[t]{4}{*}{ Jul-08 } & MO5 & 27 & 0.7566 & 0.7918 & 3.18 \\
\hline & MO6 & 28 & 0.7893 & 0.8251 & 3.215 \\
\hline & MO7 & 29 & 0.7953 & 0.8311 & 3.225 \\
\hline & MO8 & 30 & 0.7890 & 0.8247 & 2.545 \\
\hline \multirow[t]{4}{*}{ Aug-08 } & MO9 & 31 & 0.7856 & 0.8191 & 2.41 \\
\hline & MO10 & 32 & 0.7831 & 0.8163 & 3.085 \\
\hline & MO11 & 33 & 0.8084 & 0.8438 & 2.855 \\
\hline & MO12 & 34 & 0.8025 & 0.8410 & 3.275 \\
\hline \multirow[t]{8}{*}{ Sep-08 } & MO13 & 35 & 0.8186 & 0.8599 & 3.305 \\
\hline & MO14 & 36 & 0.8087 & 0.8440 & 3.16 \\
\hline & MO15 & 37 & 0.8104 & 0.8501 & 3.215 \\
\hline & MO16 & 38 & 0.8046 & 0.8432 & 3.38 \\
\hline & MO17 & 39 & 0.7849 & 0.8213 & 3.215 \\
\hline & MO18 & 40 & 0.8068 & 0.8438 & 3.425 \\
\hline & MO19 & 41 & 0.8150 & 0.8478 & 2.645 \\
\hline & MO20 & 42 & 0.8287 & 0.8711 & 3.425 \\
\hline \multirow[t]{6}{*}{ Nov-08 } & MO21 & 43 & 0.8291 & 0.8722 & 1.97 \\
\hline & MO22 & 44 & 0.8277 & 0.8785 & 3.245 \\
\hline & $\mathrm{MO} 23$ & 45 & 0.8064 & 0.8571 & 2.91 \\
\hline & MO24 & 46 & 0.8166 & 0.8673 & 2.345 \\
\hline & MO25 & 47 & 0.8005 & 0.8502 & 1.56 \\
\hline & MO26 & 48 & 0.8245 & 0.8770 & 2.6 \\
\hline \multirow[t]{4}{*}{ Dec-08 } & MO27 & 49 & 0.8171 & 0.8682 & 2.38 \\
\hline & $\mathrm{MO} 28$ & 50 & 0.8266 & 0.8809 & 3.3 \\
\hline & MO29 & 51 & 0.8184 & 0.8694 & 1.45 \\
\hline & MO30 & 52 & 0.8193 & 0.8751 & 2.73 \\
\hline \multirow[t]{4}{*}{ Jan-09 } & MO31 & 1 & 0.8120 & 0.8603 & 1.61 \\
\hline & MO32 & 2 & 0.8125 & 0.8582 & 1.985 \\
\hline & MO33 & 3 & 0.8143 & 0.8637 & 1.995 \\
\hline & MO34 & 4 & 0.8084 & 0.8569 & 3.03 \\
\hline \multirow[t]{4}{*}{ Feb-09 } & MO35 & 5 & 0.8076 & 0.8594 & 3.485 \\
\hline & MO36 & 6 & 0.8169 & 0.8653 & 3.39 \\
\hline & MO37 & 7 & 0.7663 & 0.8079 & 3.46 \\
\hline & $\mathrm{MO} 38$ & 8 & 0.7629 & 0.8034 & 3.375 \\
\hline \multirow[t]{2}{*}{ Mar-09 } & MO39 & 9 & 0.7845 & 0.8319 & 1.83 \\
\hline & MO40 & 10 & 0.7861 & 0.8251 & na \\
\hline
\end{tabular}




\begin{tabular}{|c|c|c|c|c|c|}
\hline Month & $\begin{array}{c}\text { Sample } \\
\text { No. }\end{array}$ & $\begin{array}{c}\text { Number } \\
\text { of week } \\
\text { in a year }\end{array}$ & $\begin{array}{l}\text { Casein/Total } \\
\text { Nitrogen }\end{array}$ & $\begin{array}{l}\text { Casein/True } \\
\text { Nitrogen }\end{array}$ & Fat \% \\
\hline \multirow[t]{2}{*}{ Mar 09} & MO41 & 11 & 0.8132 & 0.8548 & 1.98 \\
\hline & MO42 & 12 & 0.8066 & 0.8461 & 2.875 \\
\hline \multirow[t]{4}{*}{ Apr-09 } & MO43 & 13 & 0.7977 & 0.8366 & 1.415 \\
\hline & MO44 & 14 & 0.7716 & 0.8102 & 2.425 \\
\hline & MO45 & 15 & 0.7753 & 0.8150 & 2.3 \\
\hline & MO46 & 16 & 0.7738 & 0.8089 & 2.885 \\
\hline \multirow[t]{4}{*}{ May-09 } & MO47 & 17 & 0.7689 & 0.8071 & 1.87 \\
\hline & MO48 & 18 & 0.7750 & 0.8148 & 2.42 \\
\hline & MO49 & 19 & 0.7743 & 0.8154 & 2.29 \\
\hline & MO50 & 20 & 0.7833 & 0.8263 & 2.95 \\
\hline \multirow[t]{6}{*}{ Jun-09 } & MO51 & 21 & 0.7779 & 0.8162 & 1.435 \\
\hline & MO52 & 22 & 0.7773 & 0.8204 & 2.43 \\
\hline & MO53 & 23 & 0.7886 & 0.8318 & 2.18 \\
\hline & MO54 & 24 & 0.7745 & 0.8153 & 2.405 \\
\hline & MO55 & 25 & 0.7828 & 0.8255 & 2.02 \\
\hline & MO56 & 26 & 0.7885 & 0.8337 & 2.675 \\
\hline \multirow[t]{4}{*}{ Jul-09 } & MO57 & 27 & 0.7974 & 0.8386 & 1.87 \\
\hline & MO58 & 28 & 0.7894 & 0.8296 & 1.99 \\
\hline & MO59 & 29 & 0.7871 & 0.8231 & 1.66 \\
\hline & MO60 & 30 & 0.7989 & 0.8322 & 2.815 \\
\hline \multirow[t]{4}{*}{ Aug-09 } & MO61 & 31 & 0.7940 & 0.8374 & 2.23 \\
\hline & MO62 & 32 & 0.7844 & 0.8183 & 2.49 \\
\hline & MO63 & 33 & 0.8093 & 0.8455 & 1.64 \\
\hline & MO64 & 34 & 0.8060 & 0.8332 & 3.295 \\
\hline \multirow[t]{4}{*}{ Sep-09 } & MO65 & 35 & 0.8019 & 0.8312 & 1.85 \\
\hline & MO66 & 36 & 0.8071 & 0.8432 & 2.535 \\
\hline & MO67 & 37 & 0.7821 & 0.8143 & 2.165 \\
\hline & MO68 & 38 & 0.7922 & 0.8252 & 2.43 \\
\hline \multirow[t]{6}{*}{ Oct-09 } & MO69 & 39 & 0.7892 & 0.8239 & 2.17 \\
\hline & MO70 & 40 & 0.7948 & 0.8296 & 3.01 \\
\hline & MO71 & 41 & na & na & na \\
\hline & MO72 & 42 & na & na & na \\
\hline & MO73 & 43 & 0.7887 & 0.8271 & 4.07 \\
\hline & MO74 & 44 & 0.8071 & 0.8427 & 3.87 \\
\hline \multirow[t]{2}{*}{ Nov-09 } & MO75 & 45 & 0.8101 & 0.8387 & 2.165 \\
\hline & MO76 & 46 & 0.8050 & 0.8365 & 2.43 \\
\hline
\end{tabular}




\begin{tabular}{|c|c|c|c|c|c|}
\hline Month & $\begin{array}{c}\text { Sample } \\
\text { No. }\end{array}$ & $\begin{array}{c}\text { Number } \\
\text { of week } \\
\text { in a year }\end{array}$ & $\begin{array}{c}\text { Casein/Total } \\
\text { Nitrogen }\end{array}$ & $\begin{array}{c}\text { Casein/True } \\
\text { Nitrogen }\end{array}$ & Fat \% \\
\hline & MO77 & 47 & 0.8112 & 0.8628 & 2.17 \\
\hline & MO78 & 48 & 0.8136 & 0.8672 & 3.01 \\
\hline Dec-09 & MO79 & 49 & 0.8157 & 0.8622 & 1.41 \\
\hline & MO80 & 50 & 0.8271 & 0.8651 & 2.315 \\
\hline & MO81 & 51 & 0.8285 & 0.8770 & 1.15 \\
\hline & MO82 & 52 & 0.8146 & 0.8576 & 2.525 \\
\hline
\end{tabular}




\begin{tabular}{|c|c|c|c|c|c|c|}
\hline Month & $\begin{array}{c}\text { Sample } \\
\text { No. }\end{array}$ & $\begin{array}{c}\text { Number } \\
\text { of week } \\
\text { in a year }\end{array}$ & $\begin{array}{c}\text { Total } \\
\text { Solids\% }\end{array}$ & $\begin{array}{c}\text { Total } \\
\text { calcium \% }\end{array}$ & pH & $\begin{array}{c}\text { Somatic } \\
\text { Cells/ } \mu \\
\text { L }\end{array}$ \\
\hline \multirow[t]{4}{*}{ Jul-08 } & MO5 & 27 & 12.3800 & 0.1013 & 6.6 & 271.7 \\
\hline & MO6 & 28 & 12.2500 & 0.1025 & 6.69 & 238.3 \\
\hline & MO7 & 29 & 12.3450 & 0.1054 & 6.69 & 242.7 \\
\hline & MO8 & 30 & 11.8450 & 0.1059 & 6.71 & 190.7 \\
\hline \multirow[t]{4}{*}{ Aug-08 } & MO9 & 31 & 11.3100 & 0.1040 & 6.66 & 224.0 \\
\hline & MO10 & 32 & 11.9250 & 0.1052 & 6.66 & 241.3 \\
\hline & MO11 & 33 & 11.7750 & 0.1045 & 6.68 & 424.7 \\
\hline & MO12 & 34 & 12.1100 & 0.1055 & 6.68 & 281.7 \\
\hline \multirow[t]{8}{*}{ Sep-08 } & MO13 & 35 & 12.1550 & 0.1068 & 6.64 & 264.7 \\
\hline & MO14 & 36 & 12.1000 & 0.1066 & 6.64 & 241.0 \\
\hline & MO15 & 37 & 12.0900 & 0.1110 & 6.71 & 262.7 \\
\hline & MO16 & 38 & 12.3800 & 0.1104 & 6.71 & 122.0 \\
\hline & MO17 & 39 & 12.2950 & 0.1101 & 6.64 & 155.7 \\
\hline & MO18 & 40 & 12.3950 & 0.1078 & 6.71 & 317.7 \\
\hline & MO19 & 41 & 11.8450 & 0.1110 & 6.53 & 508.7 \\
\hline & MO20 & 42 & 12.5600 & 0.1090 & 6.6 & 258.7 \\
\hline \multirow[t]{6}{*}{ Nov-08 } & MO21 & 43 & 11.1800 & 0.1070 & 6.67 & 243.0 \\
\hline & MO22 & 44 & 12.4300 & 0.0970 & 6.69 & 244.7 \\
\hline & $\mathrm{MO} 23$ & 45 & 12.1350 & 0.0982 & 6.7 & 210.3 \\
\hline & MO24 & 46 & 11.5550 & 0.1164 & 6.68 & 219.7 \\
\hline & MO25 & 47 & 10.8300 & 0.1146 & 6.66 & 223.3 \\
\hline & MO26 & 48 & 11.8800 & 0.1148 & 6.67 & 370.3 \\
\hline \multirow[t]{4}{*}{ Dec-08 } & MO27 & 49 & 11.6450 & 0.1133 & 6.68 & 324.3 \\
\hline & $\mathrm{MO} 28$ & 50 & 12.5400 & 0.1116 & 6.65 & 266.3 \\
\hline & MO29 & 51 & 10.7350 & 0.1116 & 6.63 & 255.0 \\
\hline & MO30 & 52 & 11.9200 & 0.1200 & 6.69 & 260.3 \\
\hline \multirow[t]{4}{*}{ Jan-09 } & MO31 & 1 & 10.9300 & 0.1160 & 6.71 & 162.0 \\
\hline & MO32 & 2 & 11.2650 & 0.1134 & 6.66 & 155.0 \\
\hline & MO33 & 3 & 11.1550 & 0.1153 & 6.68 & 257.7 \\
\hline & MO34 & 4 & 12.1750 & 0.1163 & 6.65 & 435.0 \\
\hline \multirow[t]{4}{*}{ Feb-09 } & MO35 & 5 & 12.4900 & 0.1121 & 6.65 & 342.7 \\
\hline & MO36 & 6 & 12.3950 & 0.1092 & 6.63 & 260.0 \\
\hline & MO37 & 7 & 12.3750 & 0.1110 & 6.69 & 238.3 \\
\hline & MO38 & 8 & 12.2750 & 0.1126 & 6.71 & 229.7 \\
\hline \multirow[t]{2}{*}{ Mar-09 } & MO39 & 9 & 10.7900 & 0.1139 & 6.66 & 207.0 \\
\hline & MO40 & 10 & na & 0.1139 & 6.68 & 224.0 \\
\hline
\end{tabular}




\begin{tabular}{|c|c|c|c|c|c|c|}
\hline Month & $\begin{array}{c}\text { Sample } \\
\text { No. }\end{array}$ & $\begin{array}{l}\text { Number } \\
\text { of week } \\
\text { in a year }\end{array}$ & $\begin{array}{c}\text { Total } \\
\text { Solids\% }\end{array}$ & $\begin{array}{c}\text { Total } \\
\text { calcium \% }\end{array}$ & pH & $\begin{array}{c}\text { Somatic } \\
\text { Cells/ } \mu \\
\mathrm{L}\end{array}$ \\
\hline \multirow[t]{2}{*}{ Mar 09} & MO41 & 11 & 10.9750 & 0.1179 & 6.6 & 241.3 \\
\hline & MO42 & 12 & 11.7750 & 0.1163 & 6.57 & 264.7 \\
\hline \multirow[t]{4}{*}{ Apr-09 } & MO43 & 13 & 10.3550 & 0.1106 & 6.64 & 241.0 \\
\hline & MO44 & 14 & 11.0750 & 0.1108 & 6.69 & 262.7 \\
\hline & MO45 & 15 & 9.6450 & 0.1107 & 6.7 & 122.0 \\
\hline & MO46 & 16 & 11.8050 & 0.1032 & 6.69 & 155.7 \\
\hline \multirow[t]{4}{*}{ May-09 } & MO47 & 17 & 10.8150 & 0.1105 & 6.66 & 317.7 \\
\hline & MO48 & 18 & 11.3400 & 0.1125 & 6.67 & 508.7 \\
\hline & MO49 & 19 & 11.2150 & 0.1115 & 6.68 & 258.7 \\
\hline & MO50 & 20 & 11.8400 & 0.1069 & 6.66 & 243.0 \\
\hline \multirow[t]{6}{*}{ Jun-09 } & MO51 & 21 & 10.3800 & 0.0924 & 6.65 & 244.7 \\
\hline & MO52 & 22 & 11.3200 & 0.0937 & 6.66 & 210.3 \\
\hline & MO53 & 23 & 10.9750 & 0.1056 & 6.65 & 219.7 \\
\hline & MO54 & 24 & 11.2650 & 0.1046 & 6.63 & 223.3 \\
\hline & MO55 & 25 & 10.9400 & 0.1056 & 6.69 & 370.3 \\
\hline & MO56 & 26 & 11.4450 & 0.1032 & 6.71 & 324.3 \\
\hline \multirow[t]{4}{*}{ Jul-09 } & MO57 & 27 & 10.7600 & 0.1021 & 6.66 & 266.3 \\
\hline & MO58 & 28 & 10.8800 & 0.1045 & 6.68 & 255.0 \\
\hline & MO59 & 29 & 10.5500 & 0.1048 & 6.65 & 260.3 \\
\hline & MO60 & 30 & 11.6400 & 0.1050 & 6.65 & 162.0 \\
\hline \multirow[t]{4}{*}{ Aug-09 } & MO61 & 31 & 11.1000 & 0.1057 & 6.63 & 155.0 \\
\hline & MO62 & 32 & 11.3650 & 0.1081 & 6.69 & 257.7 \\
\hline & MO63 & 33 & 10.6050 & 0.1057 & 6.71 & 435.0 \\
\hline & MO64 & 34 & 12.1200 & 0.1067 & 6.66 & 342.7 \\
\hline \multirow[t]{4}{*}{ Sep-09 } & MO65 & 35 & 10.8050 & 0.0959 & 6.68 & 260.0 \\
\hline & MO66 & 36 & 11.4000 & 0.0965 & 6.6 & 238.3 \\
\hline & MO67 & 37 & 11.1000 & 0.1127 & 6.57 & 229.7 \\
\hline & MO68 & 38 & 11.3750 & 0.1152 & 6.64 & 223.3 \\
\hline \multirow[t]{6}{*}{ Oct-09 } & MO69 & 39 & 11.2100 & 0.1114 & 6.69 & 370.3 \\
\hline & MO70 & 40 & 12.0500 & 0.1091 & 6.7 & 324.3 \\
\hline & MO71 & 41 & na & na & na & na \\
\hline & MO72 & 42 & na & na & na & na \\
\hline & MO73 & 43 & 12.7000 & 0.1150 & 6.69 & 255.0 \\
\hline & MO74 & 44 & 12.8700 & 0.1142 & 6.66 & 260.3 \\
\hline \multirow[t]{2}{*}{ Nov-09 } & MO75 & 45 & 11.1000 & 0.1169 & 6.67 & 162.0 \\
\hline & MO76 & 46 & 11.3750 & 0.1072 & 6.64 & 155.0 \\
\hline
\end{tabular}




\begin{tabular}{|c|c|c|c|c|c|c|}
\hline Month & $\begin{array}{c}\text { Sample } \\
\text { No. }\end{array}$ & $\begin{array}{c}\text { Number } \\
\text { of week } \\
\text { in a year }\end{array}$ & $\begin{array}{c}\text { Total } \\
\text { Solids\% }\end{array}$ & $\begin{array}{c}\text { Total } \\
\text { calcium \% }\end{array}$ & pH & $\begin{array}{c}\text { Somatic } \\
\text { Cells/ } \boldsymbol{\mu L}\end{array}$ \\
\hline & MO77 & 47 & 11.2100 & 0.1056 & 6.71 & 257.7 \\
\hline & MO78 & 48 & 12.0500 & 0.1112 & 6.53 & 435.0 \\
\hline Dec-09 & MO79 & 49 & 10.5500 & 0.1132 & 6.6 & 342.7 \\
\hline & MO80 & 50 & 11.4150 & 0.1168 & 6.67 & 260.0 \\
\hline & MO81 & 51 & 10.2950 & 0.1124 & 6.68 & 238.3 \\
\hline & MO82 & 52 & 11.6100 & 0.1123 & 6.65 & 229.7 \\
\hline
\end{tabular}




\section{Appendix 2. Milk Statistics (analyzed in Minitab 17.0)}

\section{Descriptive Statistics of Milk Composition}

Variable
Total Protein\%
Total Nitrogen\%
True Protein \%
True Nitrogen\%
Non-Protein Nitrogen\%
Casein \%
Casein Nitrogen
Non-Casein Nitrogen\%
Casein/Total Protein
Casein/True Protein
Fat \%
Total Solids\%
Total calcium $\%$
pH
Somatic Cells/ $\mu l$

Total
Count
76
76
76
76
76
76
76
76
76
76
76
76
76
76
76

$\begin{array}{cccc}\text { Mean } & \text { StDev } & \text { Minimum } & \text { Maximum } \\ 3.2861 & 0.1105 & 3.0414 & 3.4799 \\ 0.51507 & 0.01733 & 0.47671 & 0.54544 \\ 3.1259 & 0.0968 & 2.8878 & 3.3131 \\ 0.48995 & 0.01517 & 0.45263 & 0.51929 \\ 0.025117 & 0.004225 & 0.016426 & 0.034592 \\ 2.6271 & 0.1339 & 2.3202 & 2.8488 \\ 0.41177 & 0.02099 & 0.36367 & 0.44652 \\ 0.10556 & 0.00876 & 0.08999 & 0.12804 \\ 0.79908 & 0.01773 & 0.75660 & 0.82906 \\ 0.84003 & 0.02141 & 0.79177 & 0.88089 \\ 2.5604 & 0.6553 & 1.1500 & 4.0700 \\ 11.543 & 0.680 & 9.645 & 12.870 \\ 0.10881 & 0.00582 & 0.09239 & 0.12002 \\ 6.6612 & 0.0394 & 6.5300 & 6.7100 \\ 262.61 & 79.22 & 122.00 & 508.67\end{array}$

\section{Regression Analysis of Milk for Total Nitrogen}

Total Nitrogen( \%) of milk versus Sine(week), Cosine(week)

$\begin{array}{lrrrrr}\text { Analysis of Variance } \\ \begin{array}{l}\text { Source } \\ \text { Regression }\end{array} & \text { DF } & \text { Adj SS } & \text { Adj MS } & \text { F-Value } & \text { P-Value } \\ \quad \text { Sine(week) } & 1 & 0.014289 & 0.007144 & 63.40 & 0.000 \\ \quad \text { Cosine(week) } & 1 & 0.012871 & 0.001571 & 13.94 & 0.000 \\ \text { Error } & 73 & 0.008226 & 0.000113 & & \\ \quad \text { Lack-of-Fit } & 49 & 0.006999 & 0.000143 & 2.79 & 0.004 \\ \quad \text { Pure Error } & 24 & 0.001227 & 0.000051 & & \\ \text { Total } & 75 & 0.022515 & & & \end{array}$

Model Summary

$\begin{array}{rrrr}S & R-s q & R-s q(\text { adj) } & R-s q(\text { pred) } \\ 0.0106153 & 63.46 \% & 62.46 \% & 60.01 \%\end{array}$

Coefficients

$\begin{array}{lrrrrr}\text { Term } & \text { Coef } & \text { SE Coef } & \text { T-Value } & \text { P-Value } & \text { VIF } \\ \text { Constant } & 0.51367 & 0.00127 & 405.54 & 0.000 & \\ \text { Sine(week) } & -0.00676 & 0.00181 & -3.73 & 0.000 & 1.00 \\ \text { Cosine(week) } & 0.01821 & 0.00170 & 10.69 & 0.000 & 1.00\end{array}$




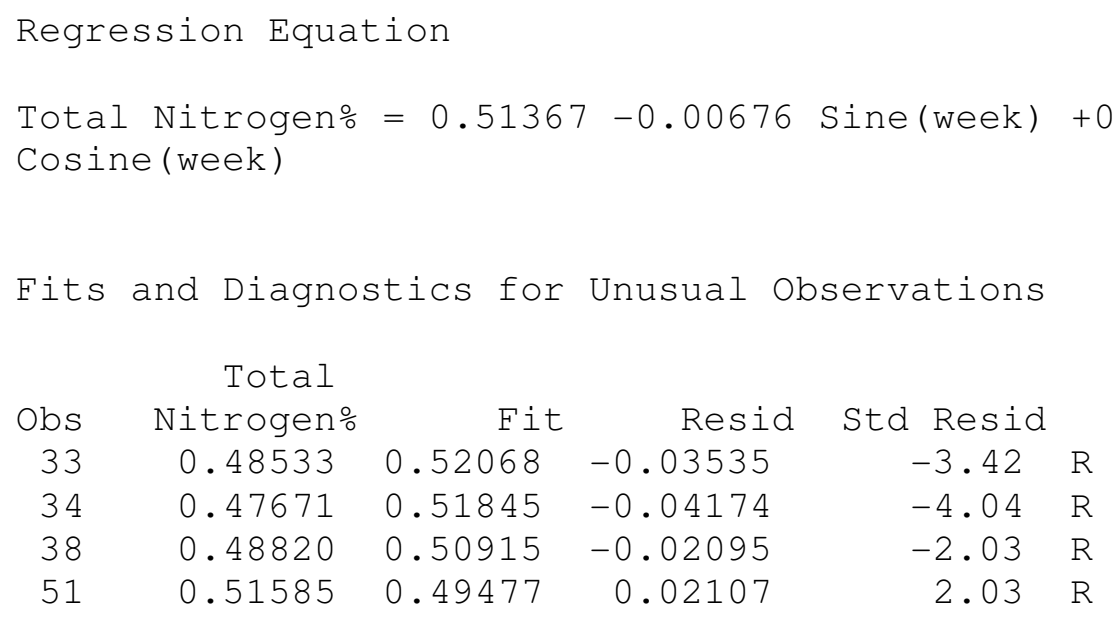

R Large residual

Normal Probability plot of Residuals for Total Nitrogen\%

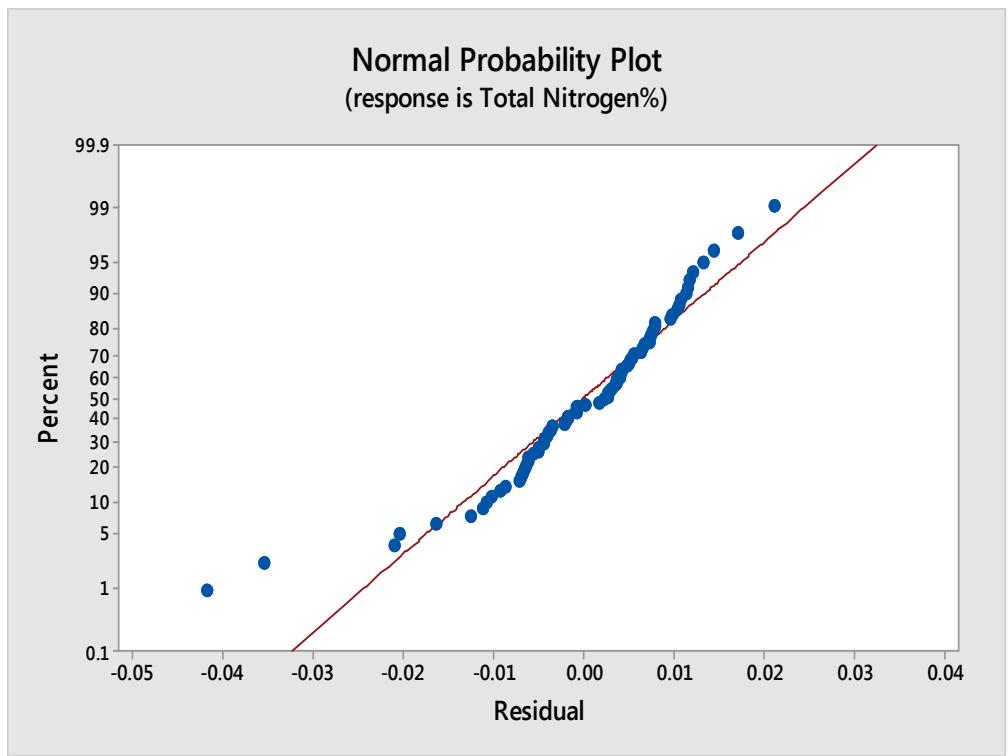


Residuals vs Fits for Total Nitrogen\%

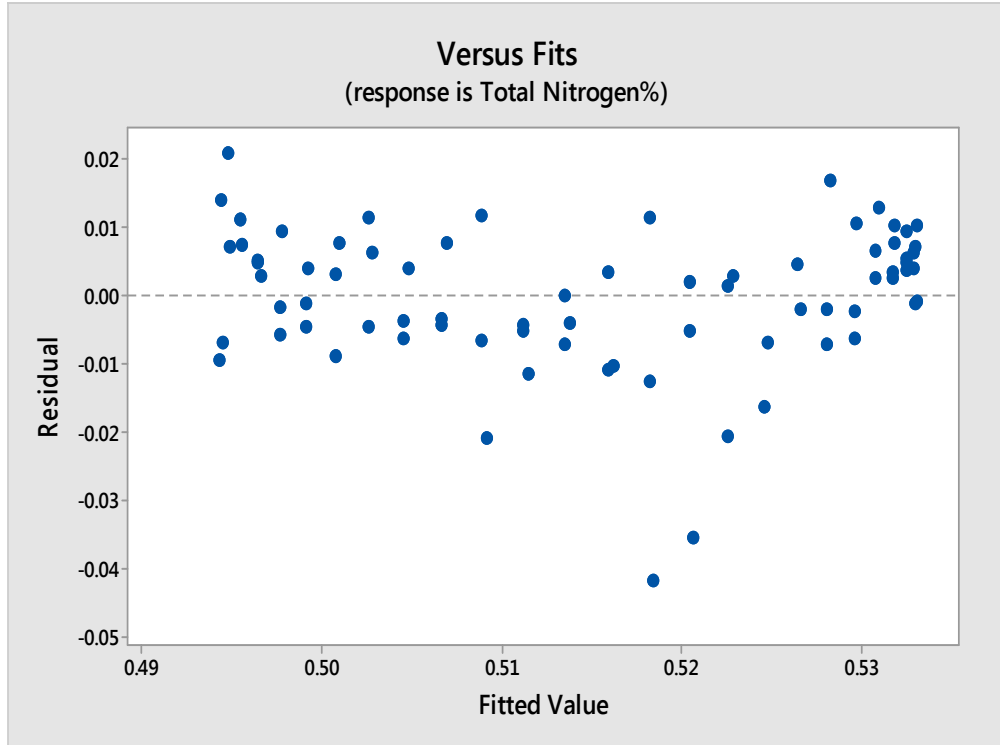

True Nitrogen\% versus Sine(week), Cosine(week)

$\begin{array}{lrrrrr}\text { Analysis of Variance } \\ \begin{array}{l}\text { Source } \\ \text { Regression }\end{array} & \text { Adj SS } & \text { Adj MS } & \text { F-Value } & \text { P-Value } \\ \text { Regre(week) } & 1 & 0.010488 & 0.005244 & 56.60 & 0.000 \\ \quad \text { Sine } & 0.002316 & 0.002316 & 25.00 & 0.000 \\ \quad \text { Cosine(week) } & 1 & 0.008323 & 0.008323 & 89.84 & 0.000 \\ \text { Error } & 73 & 0.006763 & 0.000093 & & \\ \quad \text { Lack-of-Fit } & 49 & 0.005461 & 0.000111 & 2.05 & 0.029 \\ \quad \text { Pure Error } & 24 & 0.001302 & 0.000054 & & \\ \text { Total } & 75 & 0.017251 & & & \end{array}$

Model Summary

$\begin{array}{rrrr}S & R-s q & R-s q(a d j) & R-s q(\text { pred) } \\ 0.0096252 & 60.80 \% & 59.72 \% & 57.08 \%\end{array}$

Coefficients

$\begin{array}{lrrrrr}\text { Term } & \text { Coef } & \text { SE Coef } & \text { T-Value } & \text { P-Value } & \text { VIF } \\ \text { Constant } & 0.48829 & 0.00115 & 425.16 & 0.000 & \\ \text { Sine (week) } & -0.00821 & 0.00164 & -5.00 & 0.000 & 1.00 \\ \text { Cosine(week) } & 0.01465 & 0.00155 & 9.48 & 0.000 & 1.00\end{array}$




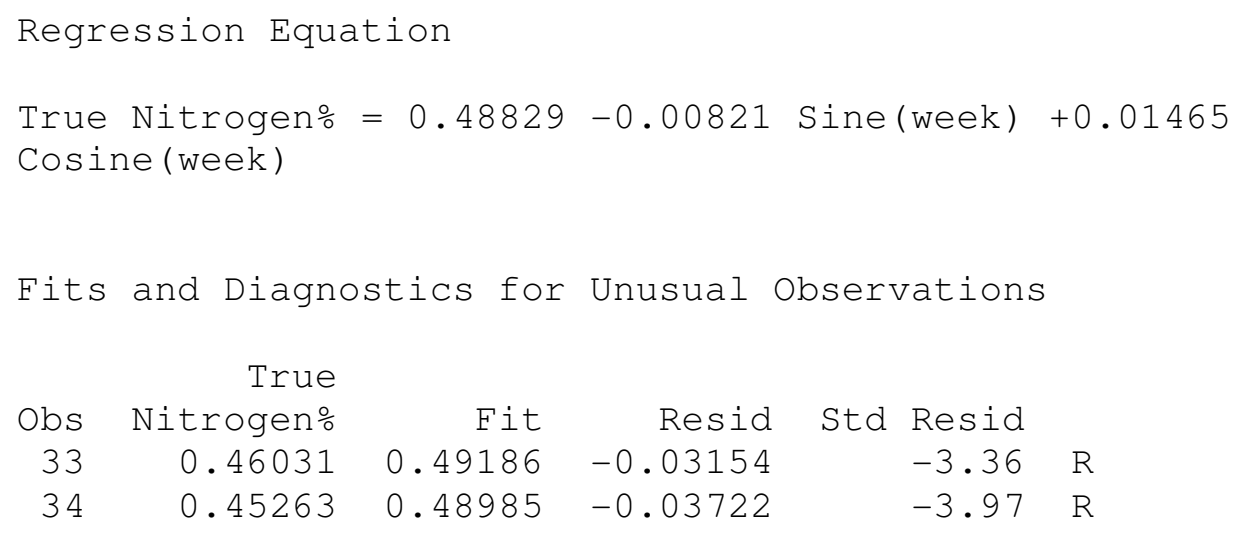

\begin{tabular}{rrrrrr}
\multicolumn{7}{c}{ True } & & & & \\
Obs & Nitrogen\% & Fit & Resid & Std Resid & \\
33 & 0.46031 & 0.49186 & -0.03154 & -3.36 & R \\
34 & 0.45263 & 0.48985 & -0.03722 & -3.97 & R
\end{tabular}

R Large residual

Normal probability plot of Residuals for True Nitrogen\%

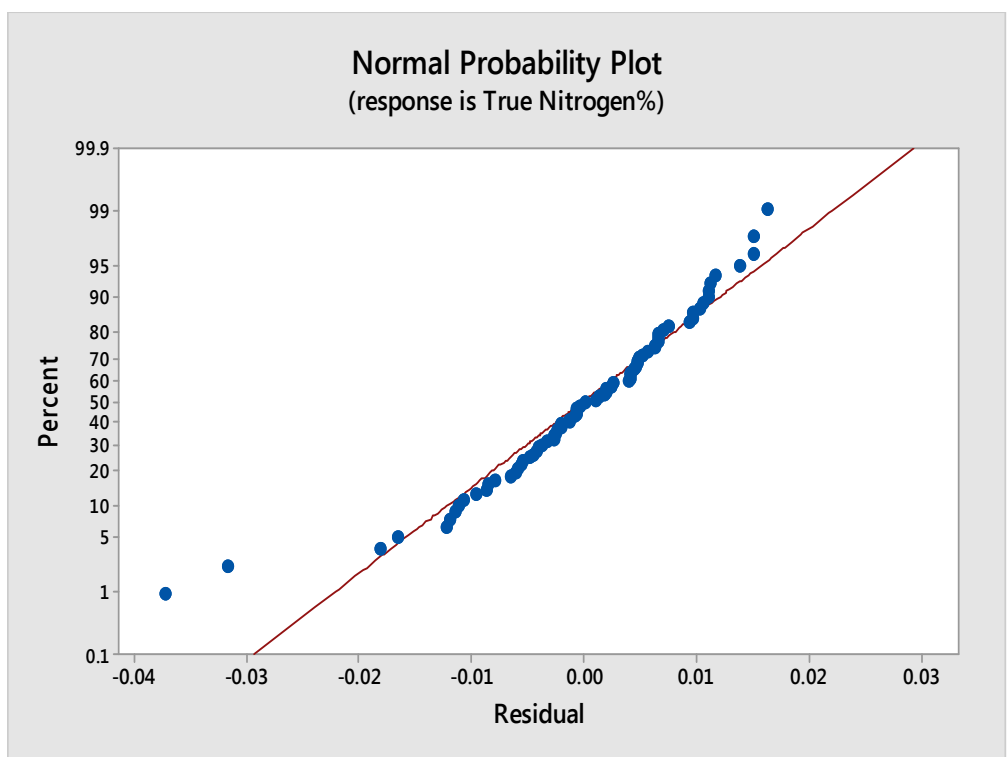


Residuals vs Fits for True Nitrogen\%

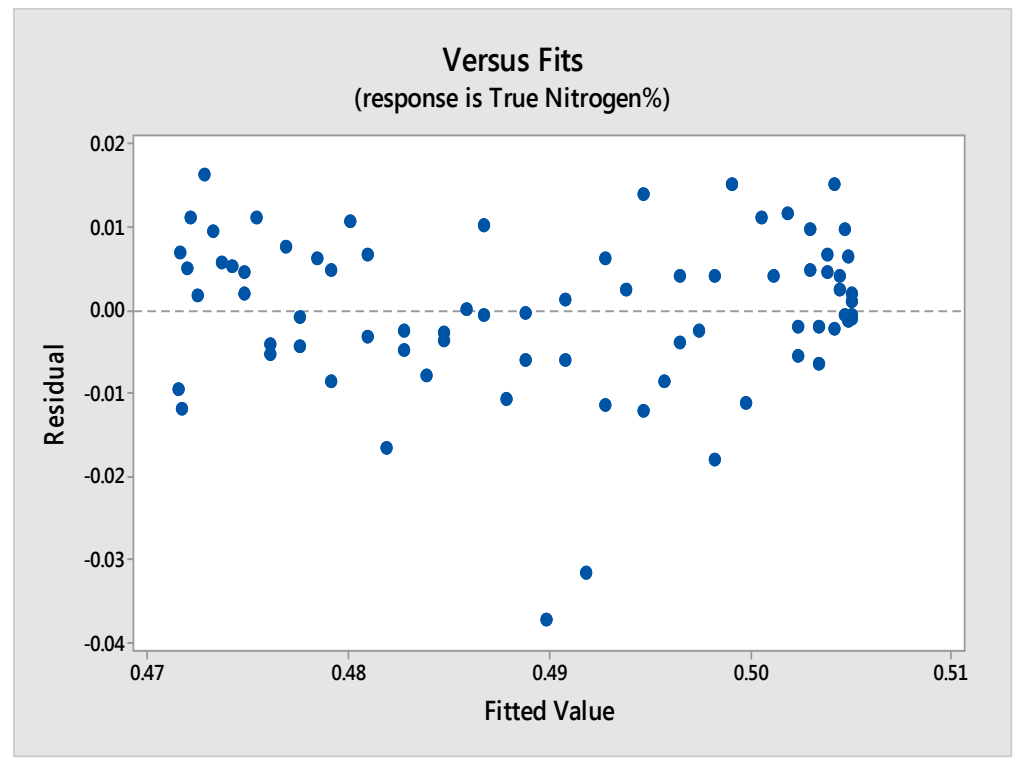

Casein Nitrogen \% versus Sine(week), Cosine(week)

$\begin{array}{lrrrrr}\text { Analysis of Variance } \\ \begin{array}{l}\text { Source } \\ \text { RF }\end{array} & \text { Adj SS } & \text { Adj MS } & \text { F-Value } & \text { P-Value } \\ \text { Regression } & 2 & 0.023255 & 0.011628 & 86.71 & 0.000 \\ \quad \text { Sine(week) } & 1 & 0.004134 & 0.004134 & 30.83 & 0.000 \\ \quad \text { Cosine(week) } & 1 & 0.019429 & 0.019429 & 144.88 & 0.000 \\ \text { Error } & 73 & 0.009789 & 0.000134 & & \\ \quad \text { Lack-of-Fit } & 49 & 0.008384 & 0.000171 & 2.92 & 0.003 \\ \quad \text { Pure Error } & 24 & 0.001406 & 0.000059 & & \\ \text { Total } & 75 & 0.033045 & & & \end{array}$

Model Summary

$\begin{array}{rrrr}S & R-s q & R-s q(a d j) & R-s q(p r e d) \\ 0.0115803 & 70.38 \% & 69.56 \% & 67.60 \%\end{array}$

Coefficients

$\begin{array}{lrrrrr}\text { Term } & \text { Coef } & \text { SE Coef } & \text { T-Value } & \text { P-Value } & \text { VIF } \\ \text { Constant } & 0.40954 & 0.00138 & 296.39 & 0.000 & \\ \text { Sine (week) } & -0.01097 & 0.00198 & -5.55 & 0.000 & 1.00 \\ \text { Cosine (week) } & 0.02238 & 0.00186 & 12.04 & 0.000 & 1.00\end{array}$



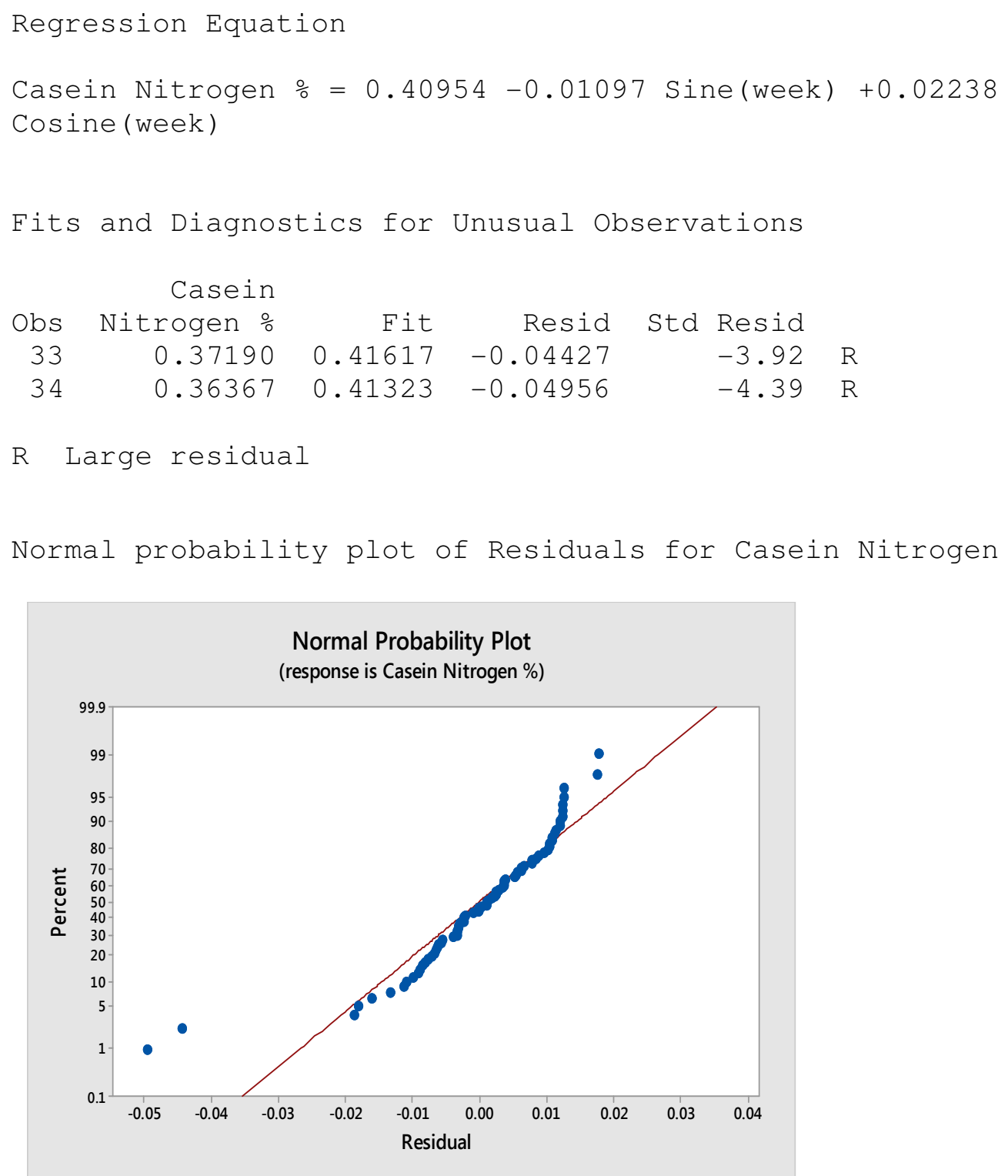
Residuals vs Fits for Casein Nitrogen \%

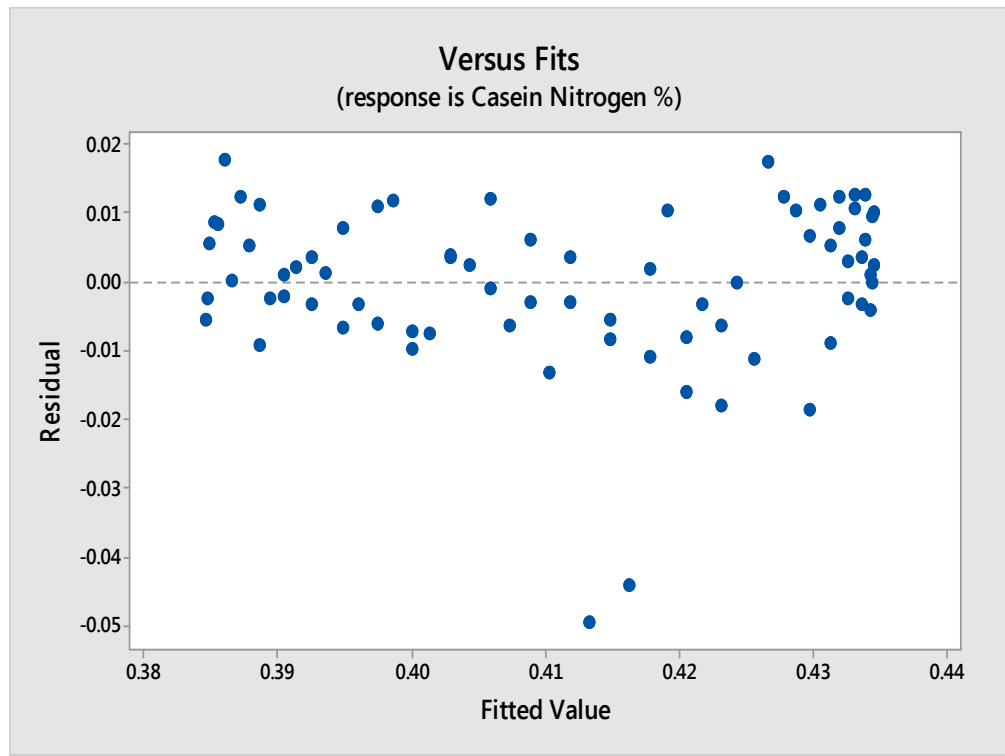

Casein to Total Nitrogen Ratio versus Sine(week), Cosine(week)

$\begin{array}{lrrrrr}\text { Analysis of Variance } \\ \begin{array}{l}\text { Source } \\ \text { Regression }\end{array} & \text { D } & \text { Adj SS } & \text { Adj MS } & \text { F-Value } & \text { P-Value } \\ \quad \text { Sine(week) } & 1 & 0.0042633 & 0.006316 & 42.12 & 0.000 \\ \quad \text { Cosine(week) } & 1 & 0.008650 & 0.004191 & 27.95 & 0.000 \\ \text { Error } & 73 & 0.010946 & 0.000150 & 57.69 & 0.000 \\ \quad \text { Lack-of-Fit } & 49 & 0.008013 & 0.000164 & 1.34 & 0.222 \\ \quad \text { Pure Error } & 24 & 0.002933 & 0.000122 & & \\ \text { Total } & 75 & 0.023579 & & & \end{array}$

Model Summary

$\begin{array}{rrrr}S & R-s q & R-s q(a d j) & R-s q(p r e d) \\ 0.0122455 & 53.58 \% & 52.30 \% & 49.52 \%\end{array}$

Coefficients

$\begin{array}{lrrrrr}\text { Term } & \text { Coef } & \text { SE Coef } & \text { T-Value } & \text { P-Value } & \text { VIF } \\ \text { Constant } & 0.79687 & 0.00146 & 545.37 & 0.000 & \\ \text { Sine (week) } & -0.01104 & 0.00209 & -5.29 & 0.000 & 1.00 \\ \text { Cosine(week) } & 0.01493 & 0.00197 & 7.60 & 0.000 & 1.00\end{array}$




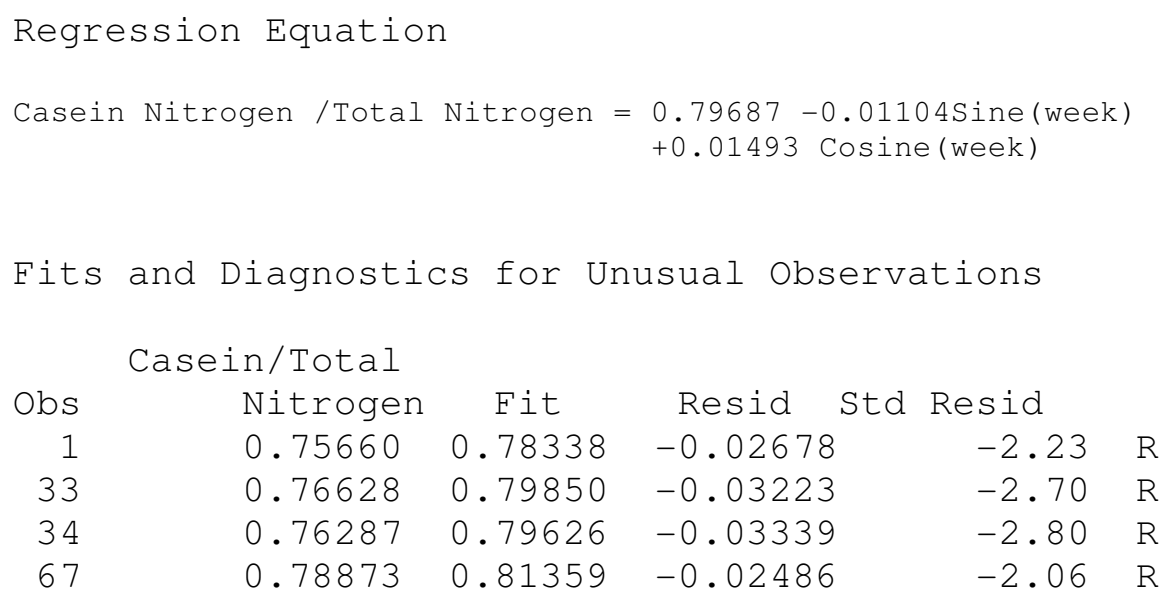

$\mathrm{R} \quad$ Large residual

Normal probability plot of Residuals for Casein to Total Protein ratio

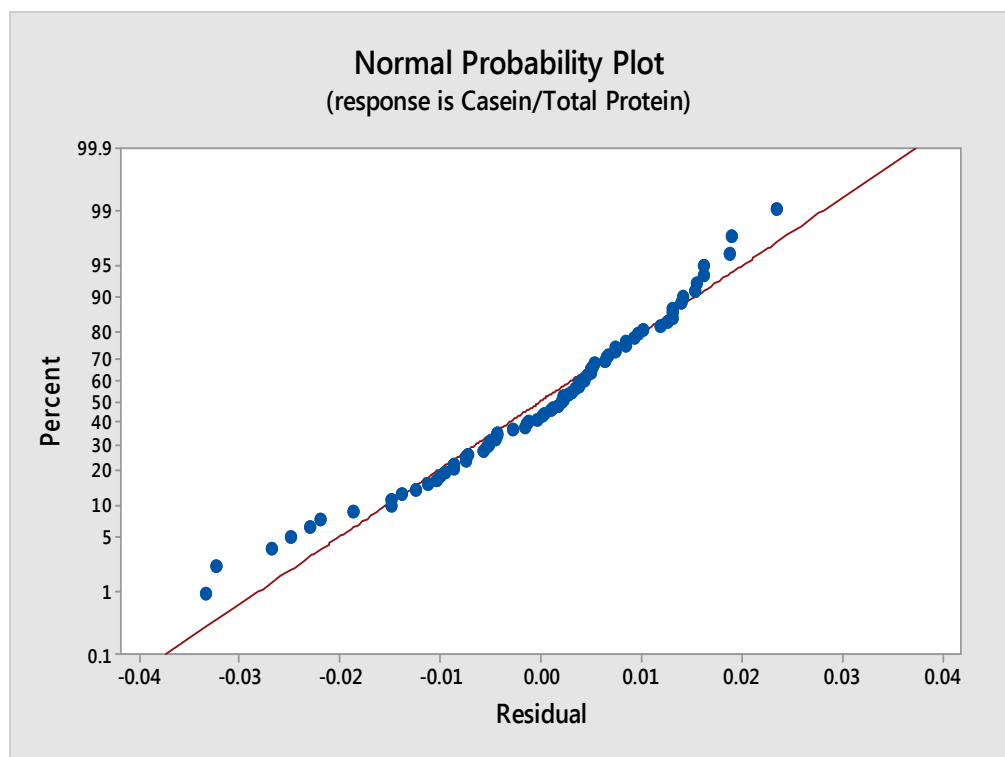


Residuals vs Fits for Casein to Total Protein ratio

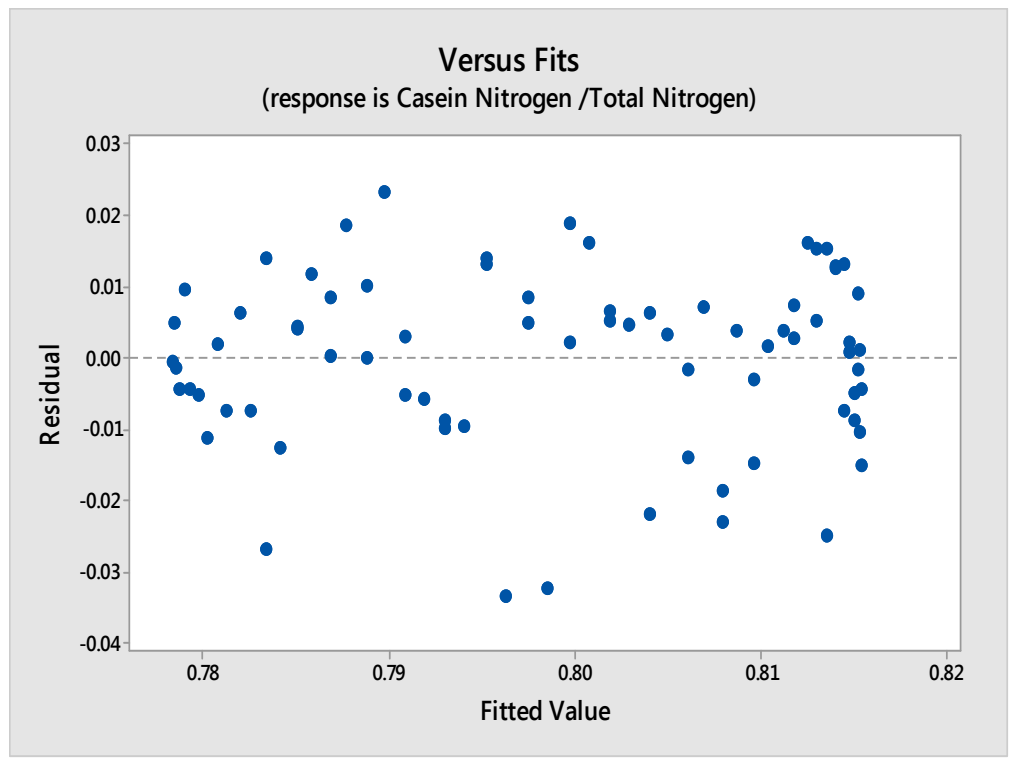

Casein to True Nitrogen ratio versus Sine(week), Cosine(week)

$\begin{array}{lrrrrr}\text { Analysis of Variance } \\ \begin{array}{l}\text { Source } \\ \text { DF }\end{array} & \text { Adj SS } & \text { Adj MS } & \text { F-Value } & \text { P-Value } \\ \text { Regression } & 2 & 0.018274 & 0.009137 & 41.38 & 0.000 \\ \quad \text { Sine(week) } & 1 & 0.002519 & 0.002519 & 11.41 & 0.001 \\ \quad \text { Cosine(week) } & 1 & 0.015972 & 0.015972 & 72.34 & 0.000 \\ \text { Error } & 73 & 0.016118 & 0.000221 & & \\ \quad \text { Lack-of-Fit } & 49 & 0.010674 & 0.000218 & 0.96 & 0.562 \\ \quad \text { Pure Error } & 24 & 0.005444 & 0.000227 & & \\ \text { Total } & 75 & 0.034392 & & & \end{array}$

Model Summary

$\begin{array}{rrrr}S & R-s q & R-s q(\operatorname{adj}) & R-s q(p r e d) \\ 0.0148593 & 53.13 \% & 51.85 \% & 49.13 \%\end{array}$

Coefficients

$\begin{array}{lrrrrr}\text { Term } & \text { Coef } & \text { SE Coef } & \text { T-Value } & \text { P-Value } & \text { VIF } \\ \text { Constant } & 0.83828 & 0.00177 & 472.79 & 0.000 & \\ \text { Sine(week) } & -0.00856 & 0.00254 & -3.38 & 0.001 & 1.00 \\ \text { Cosine(week) } & 0.02029 & 0.00239 & 8.51 & 0.000 & 1.00\end{array}$

Regression Equation 


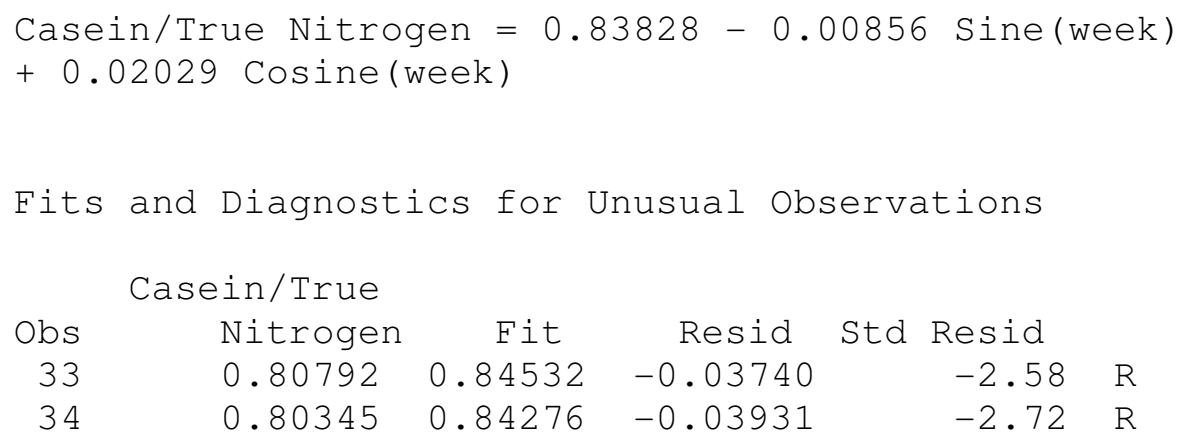

$\mathrm{R}$ Large residual

Normal Probability plot of Residuals for Casein/True Nitrogen

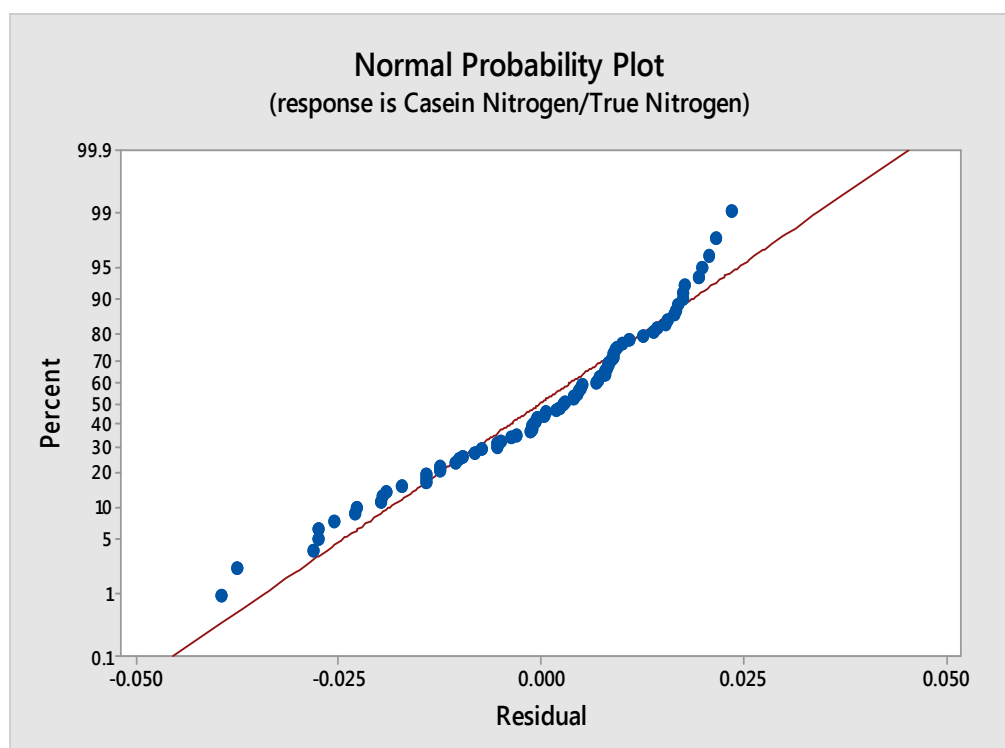


Residuals vs Fits for Casein/True Nitrogen

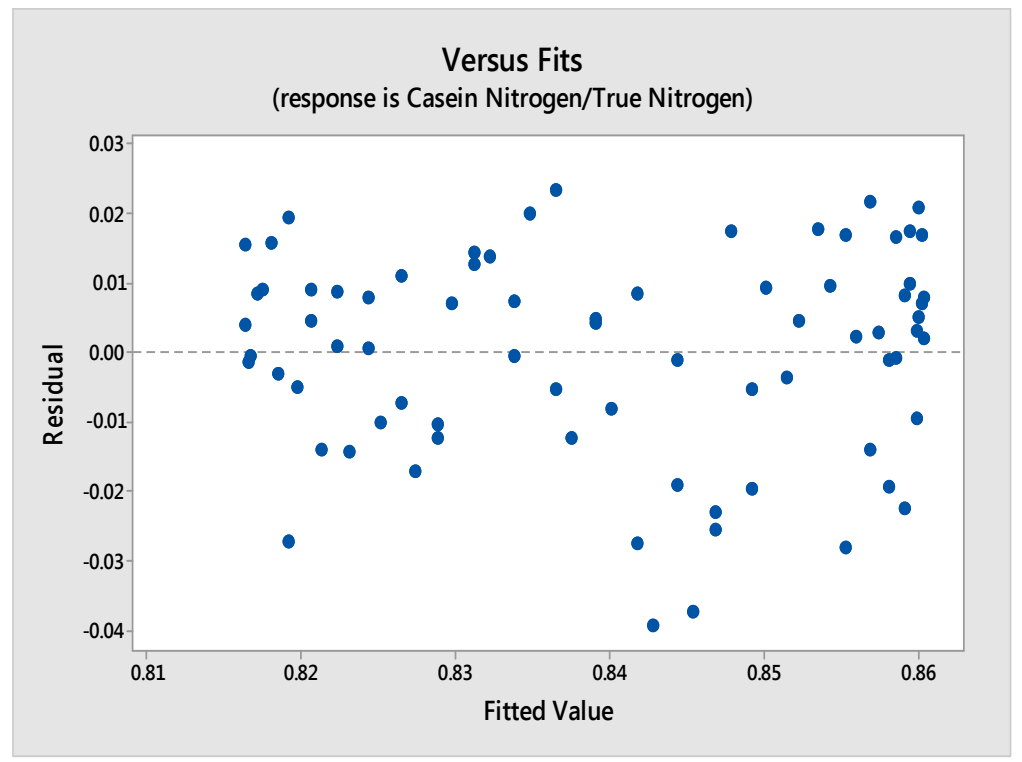

Total calcium \% versus Sine(week), Cosine(week)

\begin{tabular}{|c|c|c|c|c|c|}
\hline Source & $\mathrm{DF}$ & Adj $S S$ & Adj MS & F-Value & P-Value \\
\hline Regression & 2 & 0.000821 & 0.000411 & 48.86 & 0.000 \\
\hline Sine (week) & 1 & 0.000028 & 0.000028 & 3.32 & 0.088 \\
\hline Cosine (week) & 1 & 0.000774 & 0.000774 & 92.04 & 0.000 \\
\hline Error & 73 & 0.001501 & 0.000021 & & \\
\hline Lack-of-Fit & 49 & 0.000877 & 0.000018 & 0.69 & 0.868 \\
\hline Pure Error & 24 & 0.000625 & 0.000026 & & \\
\hline Total & 75 & 0.002542 & & & \\
\hline
\end{tabular}

Model Summary

$\begin{array}{rrrr}S & R-s q & R-s q(\text { adj) } & R-s q(\text { pred }) \\ 0.0028994 & 59.32 \% & 58.11 \% & 55.51 \%\end{array}$

Coefficients

$\begin{array}{lrrrrr}\text { Term } & \text { Coef } & \text { SE Coef } & \text { T-Value } & \text { P-Value } & \text { VIF } \\ \text { Constant } & 0.109990 & 0.000359 & 306.77 & 0.000 & \\ \text { Sine (week) } & 0.000941 & 0.000517 & 2.01 & 0.048 & 1.00 \\ \text { Cosine(week) } & 0.004630 & 0.000483 & 9.59 & 0.000 & 1.00\end{array}$

Regression Equation

Total calcium $\frac{\circ}{0}=0.109990+0.000941$ Sine (week)

+0.004630 Cosine (week) 


\begin{tabular}{lrrrrr} 
Fits and Diagnostics for Unusual Observations & \\
\multicolumn{7}{c}{ Total } & Fit & Resid & Std Resid & \\
Obs & Calcium & & & \\
37 & 0.117902 & 0.112012 & 0.005890 & 2.09 & R \\
42 & 0.103170 & 0.109228 & -0.006058 & -2.15 & R \\
64 & 0.115250 & 0.108497 & 0.006752 & 2.37 & R \\
71 & 0.105581 & 0.113266 & -0.007685 & -2.70 & R
\end{tabular}

Normal Probability plot of Residuals for Total calcium \%

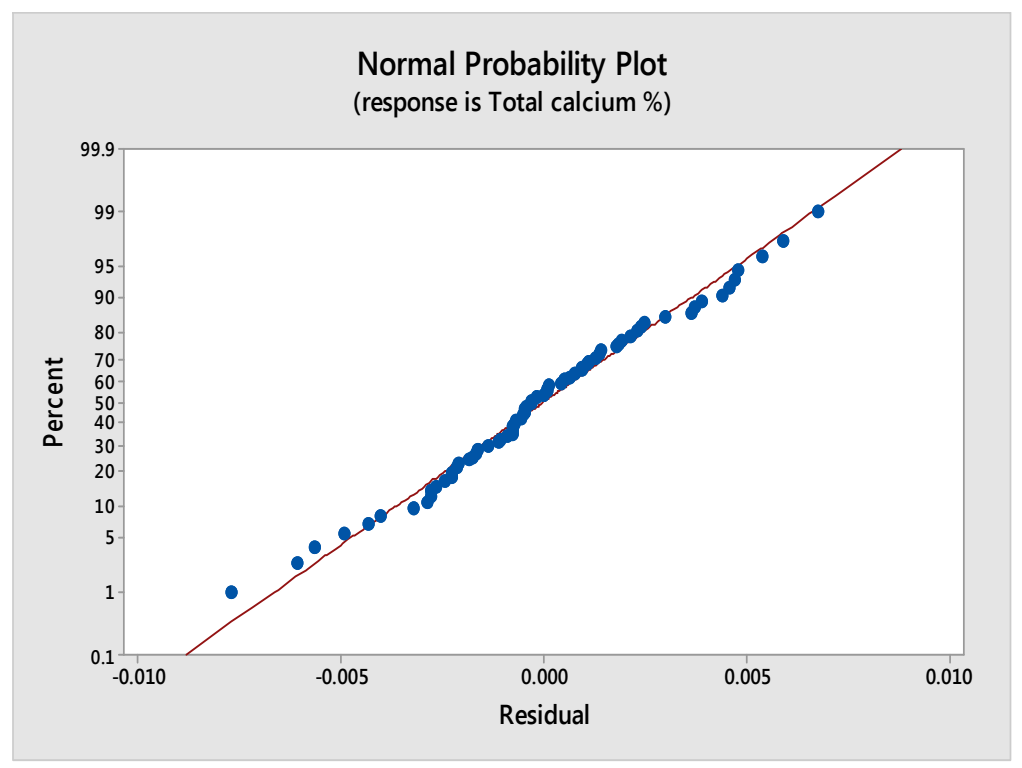

Residuals vs Fits for Total calcium 응

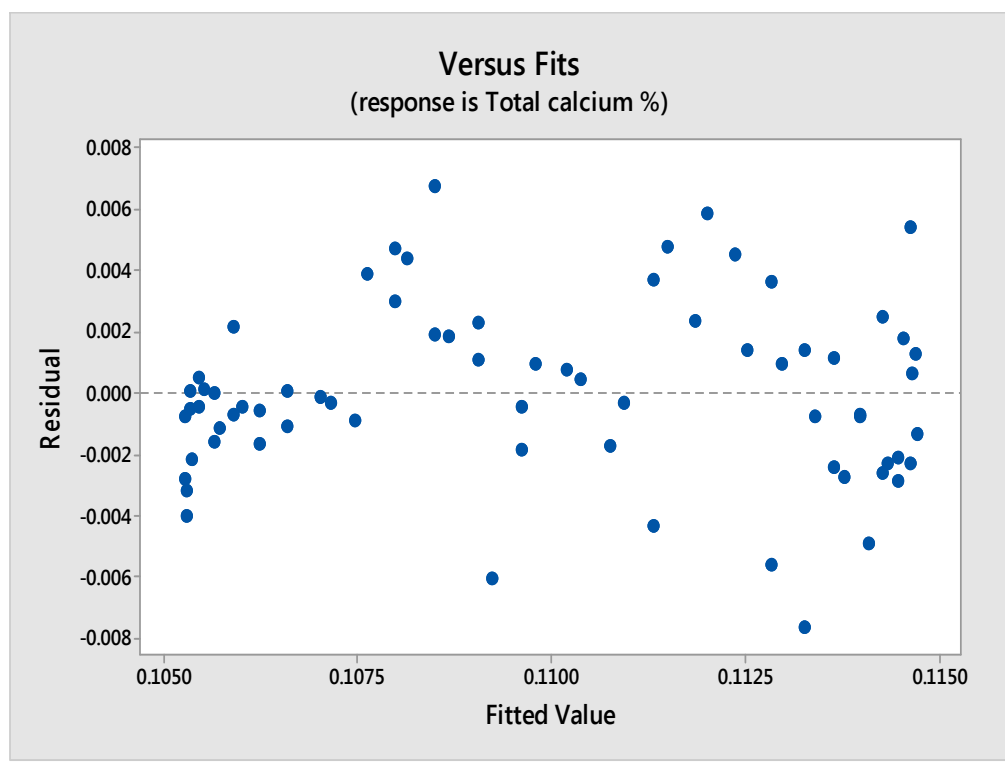




\section{Non-Casein Nitrogen\% versus Sine(week), Cosine(week)}

$\begin{array}{lrrrrr}\text { Analysis of Variance } \\ \begin{array}{l}\text { Source } \\ \text { Regression }\end{array} \quad 2 & 0.000396 & 0.000198 & 2.70 & 0.074 \\ \quad \text { Sine(week) } & 1 & 0.000393 & 0.000393 & 5.35 & 0.023 \\ \quad \text { Cosine(week) } & 1 & 0.000004 & 0.000004 & 0.06 & 0.813 \\ \text { Error } & 73 & 0.005362 & 0.000073 & & \\ \quad \text { Lack-of-Fit } & 49 & 0.002978 & 0.000061 & 0.61 & 0.927 \\ \quad \text { Pure Error } & 24 & 0.002383 & 0.000099 & & \\ \text { Total } & 75 & 0.005758 & & & \end{array}$

Model Summary

$\begin{array}{rrrr}S & R-s q & R-s q(a d j) & R-s q(\text { pred }) \\ 0.0085701 & 6.88 \% & 4.33 \% & 0.00 \%\end{array}$

Coefficients

$\begin{array}{lrrrrr}\text { Term } & \text { Coef } & \text { SE Coef } & \text { T-Value } & \text { P-Value } & \text { VIF } \\ \text { Constant } & 0.10621 & 0.00102 & 103.87 & 0.000 & \\ \text { Sine(week) } & 0.00338 & 0.00146 & 2.31 & 0.023 & 1.00 \\ \text { Cosine(week) } & -0.00033 & 0.00138 & -0.24 & 0.813 & 1.00\end{array}$

Regression Equation

Non-Casein Nitrogen\% $=0.10621+0.00338$ Sine (week) -0.00033

Cosine (week)

Normal Probability plot of Residuals for Non-Casein Nitrogen\%

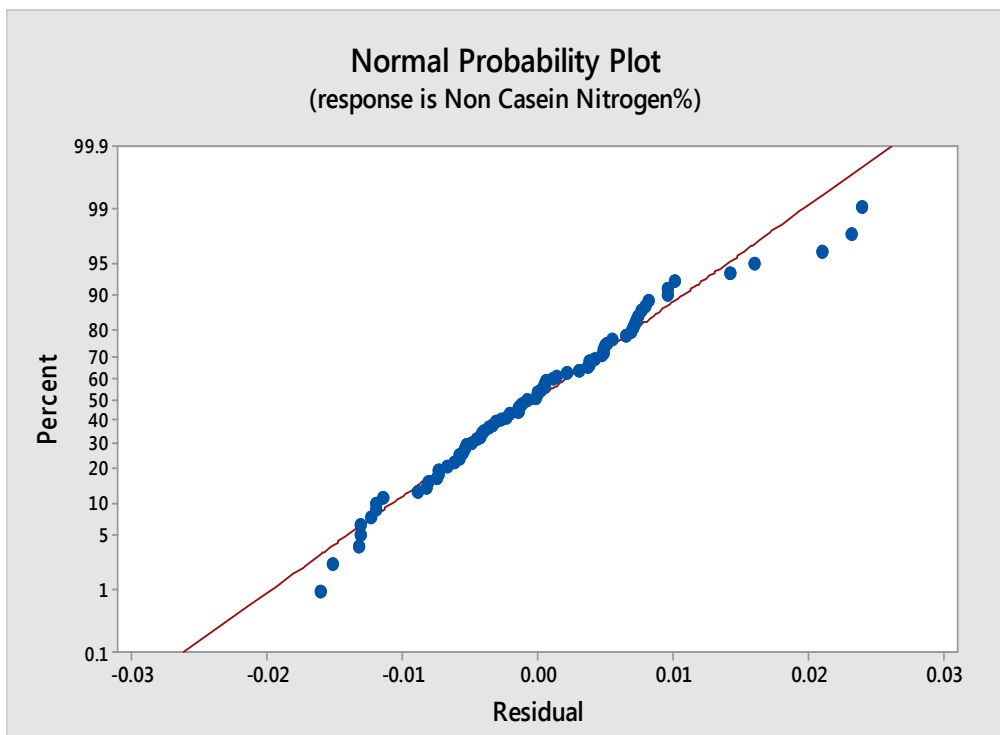


Residuals vs Fits for Non-Casein Nitrogen\%

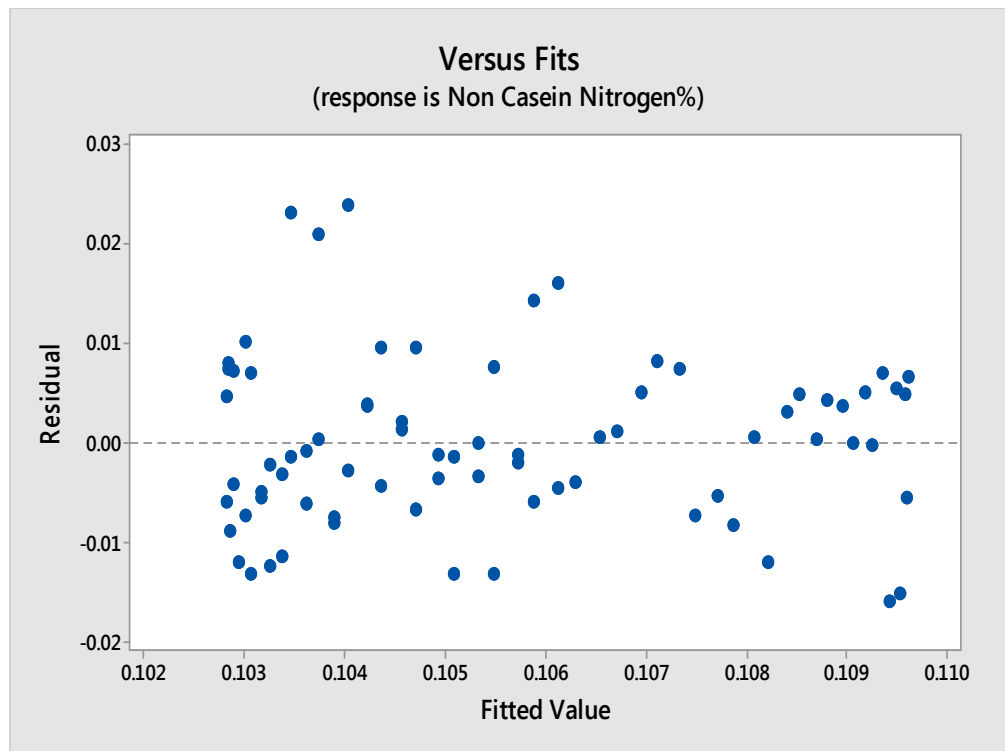

Non-Protein Nitrogen\% versus Sine(week), Cosine(week)

$\begin{array}{lrrrrr}\text { Analysis of Variance } \\ \begin{array}{l}\text { Source } \\ \text { Regression }\end{array} \quad 2 & 0.000573 & 0.000286 & 27.29 & 0.000 \\ \quad \text { Sine(week) } & 1 & 0.000072 & 0.000072 & 6.87 & 0.011 \\ \quad \text { Cosine(week) } & 1 & 0.000494 & 0.000494 & 47.06 & 0.000 \\ \text { Error } & 73 & 0.000766 & 0.000010 & & \\ \quad \text { Lack-of-Fit } & 49 & 0.000410 & 0.000008 & 0.56 & 0.955 \\ \quad \text { Pure Error } & 24 & 0.000356 & 0.000015 & & \\ \text { Total } & 75 & 0.001339 & & & \end{array}$

Model Summary

$\begin{array}{rrrr}S & R-s q & R-s q(\text { adj) } & \text { R-sq(pred) } \\ 0.0032392 & 42.78 \% & 41.21 \% & 38.12 \%\end{array}$

Coefficients

$\begin{array}{lrrrrr}\text { Term } & \text { Coef } & \text { SE Coef } & \text { T-Value } & \text { P-Value } & \text { VIF } \\ \text { Constant } & 0.025377 & 0.000387 & 65.66 & 0.000 & \\ \text { Sine(week) } & 0.001448 & 0.000553 & 2.62 & 0.011 & 1.00 \\ \text { Cosine(week) } & 0.003567 & 0.000520 & 6.86 & 0.000 & 1.00\end{array}$

Regression Equation

Non-Protein Nitrogen\% $=0.025377+0.001448$ Sine(week) +0.003567 Cosine (week) 
Normal Probability plot of Residuals for Non-Protein Nitrogen\%

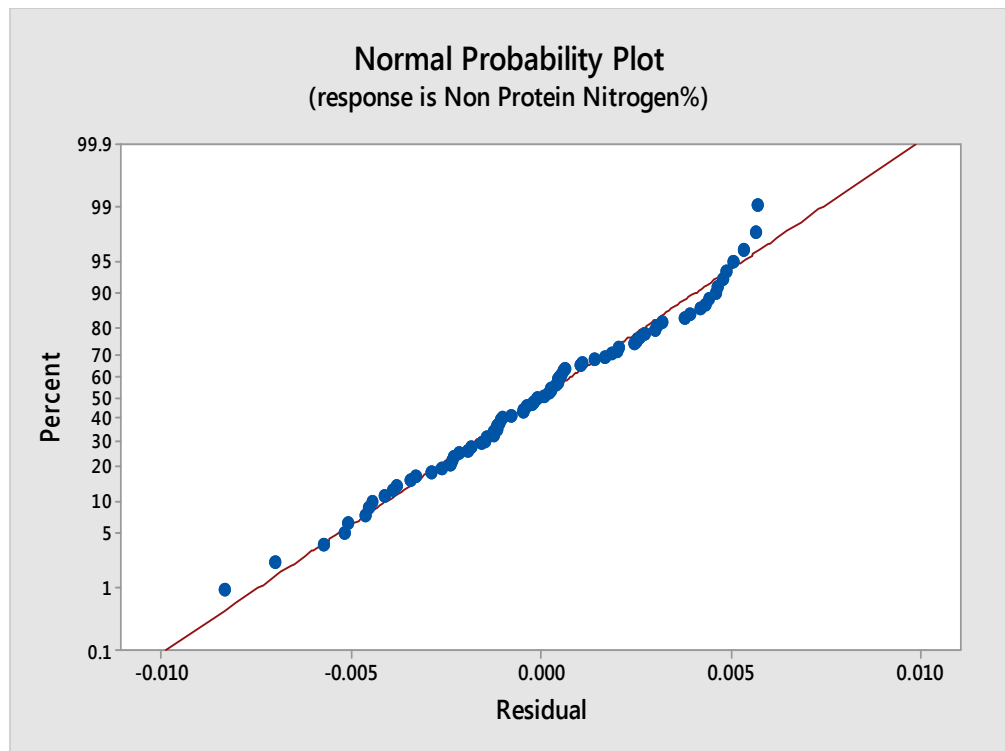

Residuals vs Fits for Non-Protein Nitrogen\%

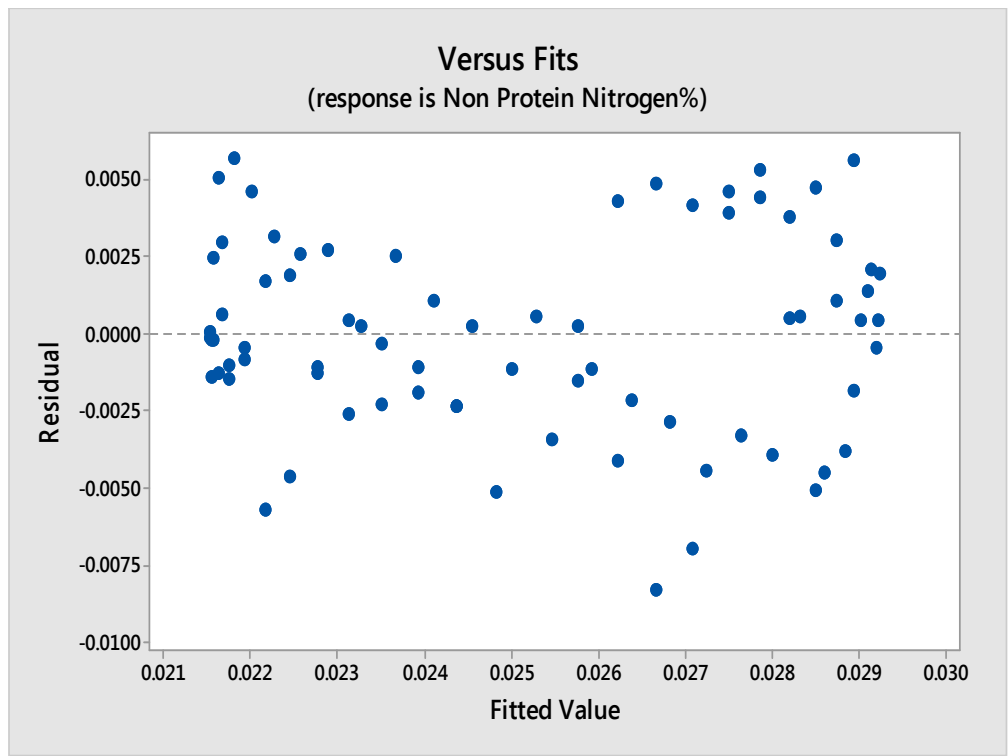

Fat \% versus Sine(week), Cosine(week)

Analysis of Variance
$\begin{array}{lrrrrr}\text { Source } & \text { DF } & \text { Adj SS } & \text { Adj MS } & \text { F-Value } & \text { P-Value } \\ \text { Regression } & 2 & 1.6008 & 0.80039 & 1.91 & 0.156 \\ \quad \text { Sine(week) } & 1 & 1.5998 & 1.59975 & 3.82 & 0.055 \\ \quad \text { Cosine(week) } & 1 & 0.0006 & 0.00056 & 0.00 & 0.971 \\ \text { Error } & 72 & 30.1730 & 0.41907 & & \end{array}$




$\begin{array}{cccccc}\text { Lack-of-Fit } & 48 & 19.5105 & 0.40647 & 0.91 & 0.614 \\ \text { Pure Error } & 24 & 10.6625 & 0.44427 & & \\ \text { Total } & 74 & 31.7738 & & & \end{array}$

Model Summary

$\begin{array}{rrrr}S & R-s q & R-s q(a d j) & R-s q(\text { pred }) \\ 0.647356 & 5.04 \% & 2.40 \% & 0.00 \%\end{array}$

Coefficients

$\begin{array}{lrrrrr}\text { Term } & \text { Coef } & \text { SE Coef } & \text { T-Value } & \text { P-Value } & \text { VIF } \\ \text { Constant } & 2.5148 & 0.0783 & 32.11 & 0.000 & \\ \text { Sine (week) } & -0.220 & 0.113 & -1.95 & 0.055 & 1.00 \\ \text { Cosine(week) } & -0.004 & 0.104 & -0.04 & 0.971 & 1.00\end{array}$

Regression Equation

Fat $\%=2.5148-0.220$ Sine (week) - 0.004 Cosine (week)

Normal Probability plot of Residuals for Fat \%

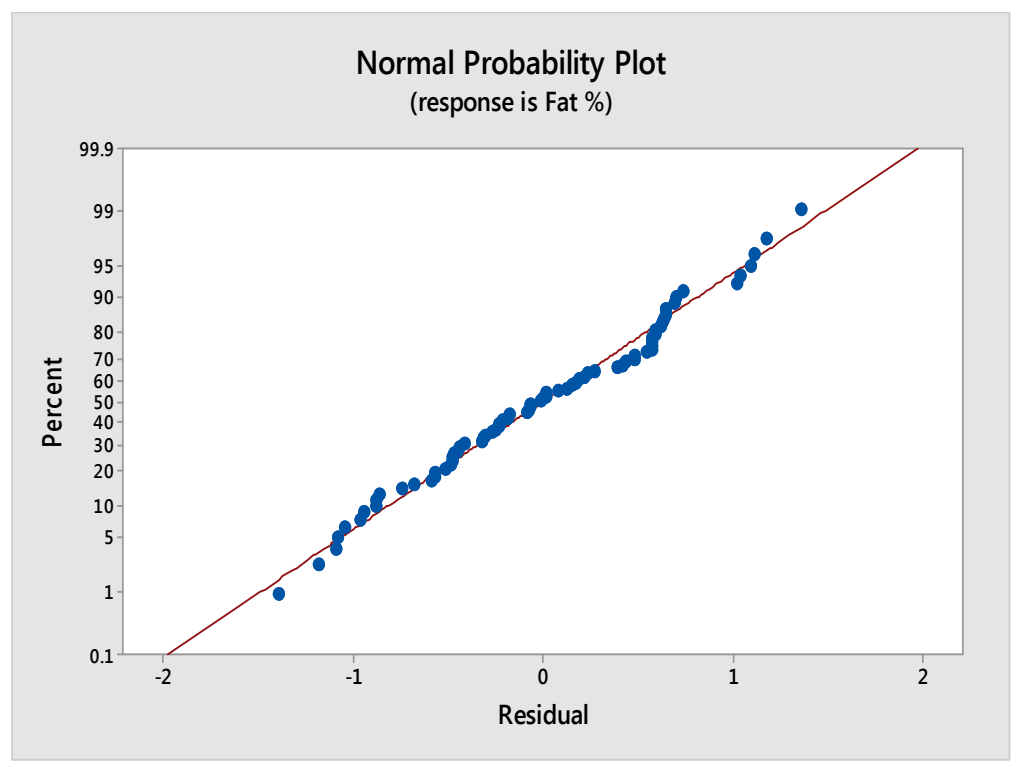


Residuals vs Fits for Fat 은

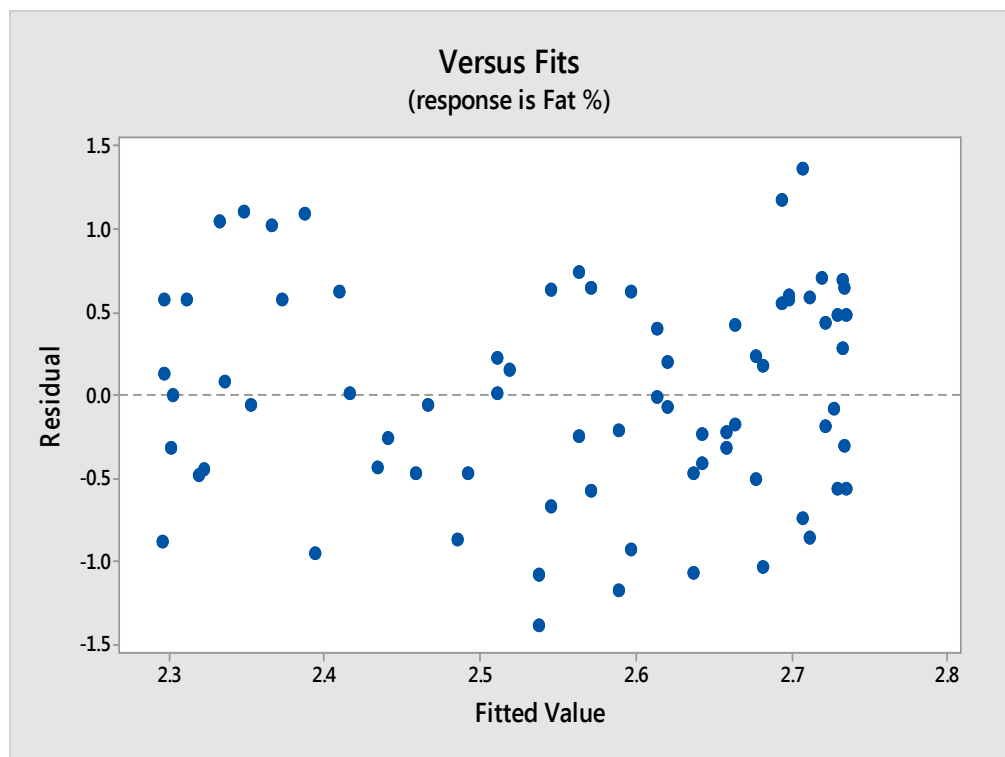

Total Solids\% versus Sine(week), Cosine(week)

\begin{tabular}{|c|c|c|c|c|c|}
\hline Source & $\mathrm{DF}$ & Adj SS & Adj MS & F-Value & P-Value \\
\hline Regression & 2 & 3.8053 & 1.9026 & 4.50 & 0.014 \\
\hline Sine (week) & 1 & 3.1523 & 3.1523 & 7.46 & 0.008 \\
\hline Cosine (week) & 1 & 0.6726 & 0.6726 & 1.59 & 0.211 \\
\hline Error & 72 & 30.4408 & 0.4228 & & \\
\hline Lack-of-Fit & 48 & 19.6277 & 0.4089 & 0.91 & 0.623 \\
\hline Pure Error & 24 & 10.8131 & 0.4505 & & \\
\hline Total & 74 & 34.2461 & & & \\
\hline
\end{tabular}

Model Summary

$\begin{array}{rrrr}S & R-s q & R-s q(\text { adj }) & R-s q(\text { pred }) \\ 0.650222 & 11.11 \% & 8.64 \% & 3.24 \%\end{array}$

Coefficients

$\begin{array}{lrrrrr}\text { Term } & \text { Coef } & \text { SE Coef } & \text { T-Value } & \text { P-Value } & \text { VIF } \\ \text { Constant } & 11.4793 & 0.0787 & 145.94 & 0.000 & \\ \text { Sine(week) } & -0.309 & 0.113 & -2.73 & 0.008 & 1.00 \\ \text { Cosine(week) } & 0.132 & 0.105 & 1.26 & 0.211 & 1.00\end{array}$

Regression Equation

Total Solids\% $=11.4793-0.309$ Sine(week) +0.132 Cosine(week) 
Normal Probability plot of Residuals for Total Solids\%

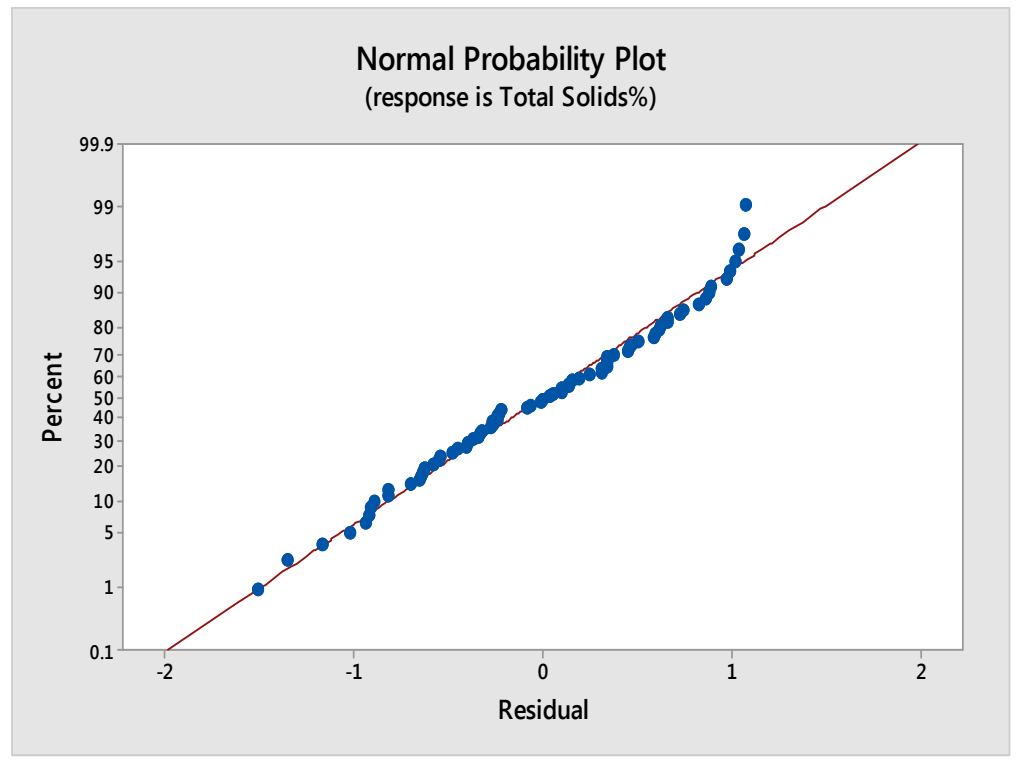

Residuals vs Fits for Total Solids\%

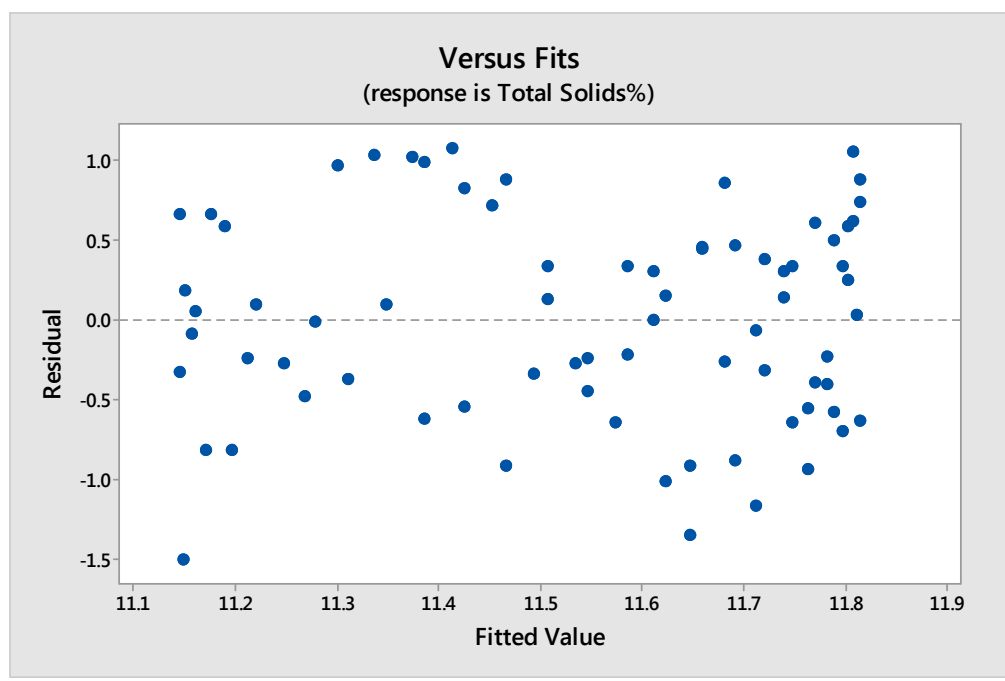

pH versus Sine(week), Cosine(week)

\begin{tabular}{|c|c|c|c|c|c|}
\hline Source & $\mathrm{DF}$ & Adj $S S$ & Adj MS & F-Value & P-Value \\
\hline Regression & 2 & 0.000590 & 0.000295 & 0.19 & 0.831 \\
\hline Sine (week) & 1 & 0.000034 & 0.000034 & 0.02 & 0.883 \\
\hline Cosine (week) & 1 & 0.000560 & 0.000560 & 0.35 & 0.554 \\
\hline Error & 73 & 0.115803 & 0.001586 & & \\
\hline Lack-of-Fit & 49 & 0.076253 & 0.001556 & 0.94 & 0.580 \\
\hline Pure Error & 24 & 0.039550 & 0.001648 & & \\
\hline
\end{tabular}


Total $\quad 75 \quad 0.116393$

Model Summary

\begin{tabular}{|c|c|c|c|c|c|c|}
\hline S & $R-s q$ & $R-s q$ & adj ) & I (pred) & & \\
\hline 0.0398290 & $0.51 \%$ & & $00 \%$ & $0.00 \%$ & & \\
\hline Coefficient. & & & & & & \\
\hline Term & & Coef & SE Coef & T-Value & P-Value & VIF \\
\hline Constant & & 5.66140 & 0.00475 & 1401.68 & 0.000 & \\
\hline Sine (week) & & .00100 & 0.00679 & 0.15 & 0.883 & 1.00 \\
\hline Cosine (week & & .00380 & 0.00639 & -0.59 & 0.554 & 1.00 \\
\hline
\end{tabular}

Regression Equation

$\mathrm{pH}=6.66140+0.00100 \operatorname{Sine}($ week $)-0.00380$ Cosine $($ week $)$

Normal Probability plot of Residuals for $\mathrm{pH}$

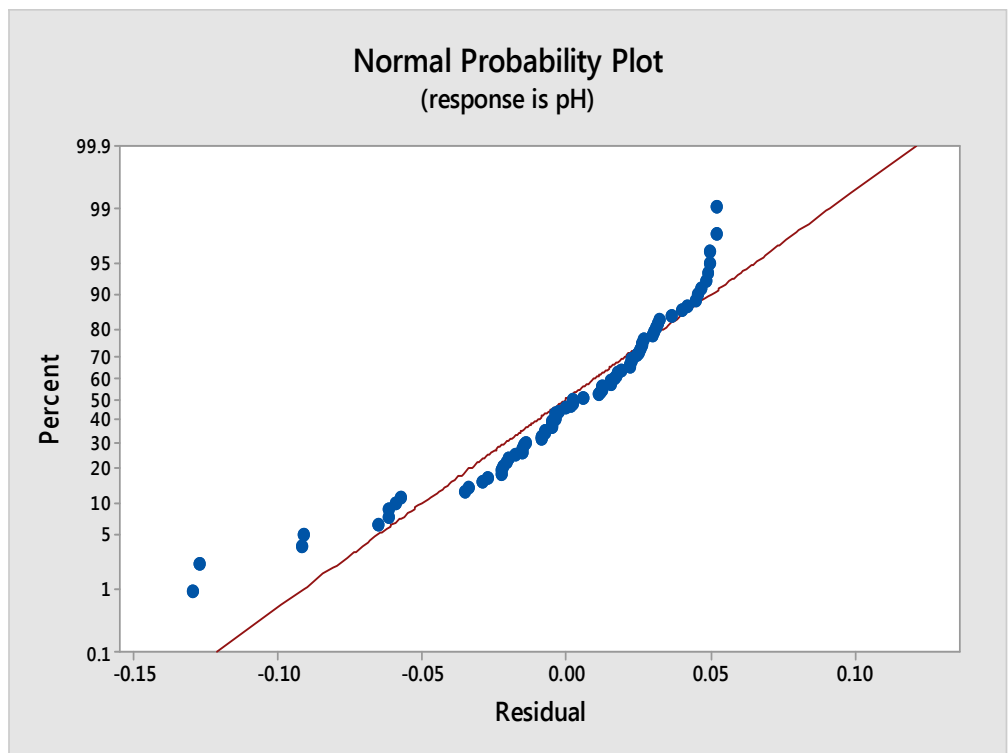


Residuals vs Fits for $\mathrm{pH}$

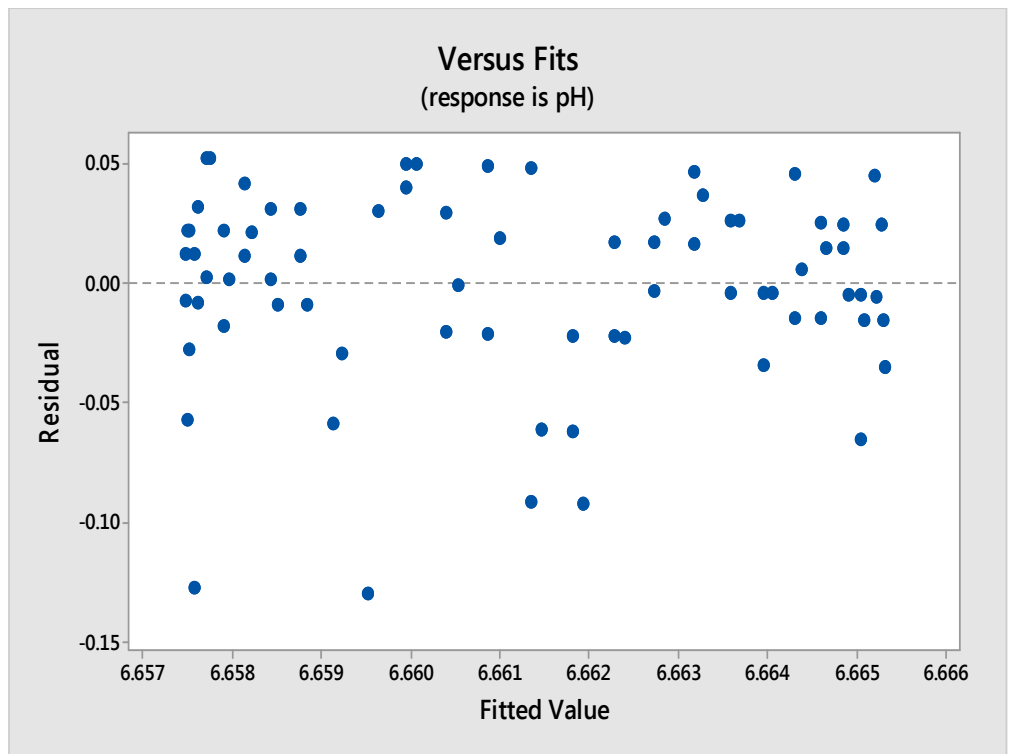

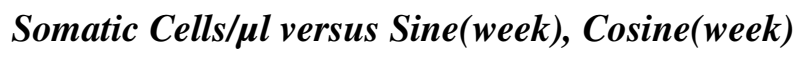

\begin{tabular}{|c|c|c|c|c|c|}
\hline Source & $\mathrm{DF}$ & Adj $S S$ & Adj MS & F-Value & P-Value \\
\hline Regression & 2 & 2098 & 1049.00 & 0.16 & 0.850 \\
\hline Sine (week) & 1 & 2068 & 2067.96 & 0.32 & 0.572 \\
\hline Cosine (week) & 1 & 39 & 39.43 & 0.01 & 0.938 \\
\hline Error & 73 & 468553 & 6418.53 & & \\
\hline Lack-of-Fit & 49 & 427717 & 8728.92 & 5.13 & 0.000 \\
\hline Pure Error & 24 & 40835 & 1701.47 & & \\
\hline Total & 75 & 470651 & & & \\
\hline
\end{tabular}

Model Summary

$\begin{array}{rrrr}S & R-s q & R-s q(a d j) & R-s q(\text { pred }) \\ 80.1157 & 0.45 \% & 0.00 \% & 0.00 \%\end{array}$

Coefficients

$\begin{array}{lrrrrr}\text { Term } & \text { Coef } & \text { SE Coef } & \text { T-Value } & \text { P-Value } & \text { VIF } \\ \text { Constant } & 261.11 & 9.56 & 27.31 & 0.000 & \\ \text { Sine (week) } & -7.8 & 13.7 & -0.57 & 0.572 & 1.00 \\ \text { Cosine(week) } & 1.0 & 12.9 & 0.08 & 0.938 & 1.00\end{array}$

Regression Equation

Somatic Cells/mic L $=261.11-7.8$ Sine(week) + 1.0 Cosine(week) 
Normal Probability plot of Residuals for Somatic Cells/ $\mu l$

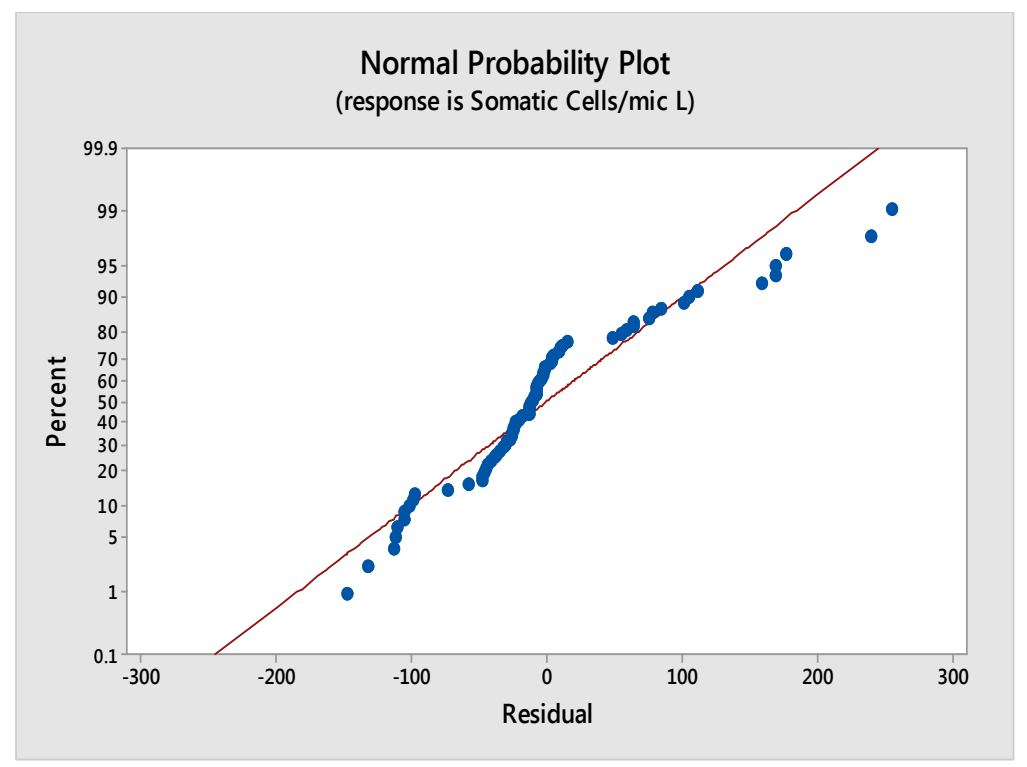

Residuals vs Fits for Somatic Cells/ul

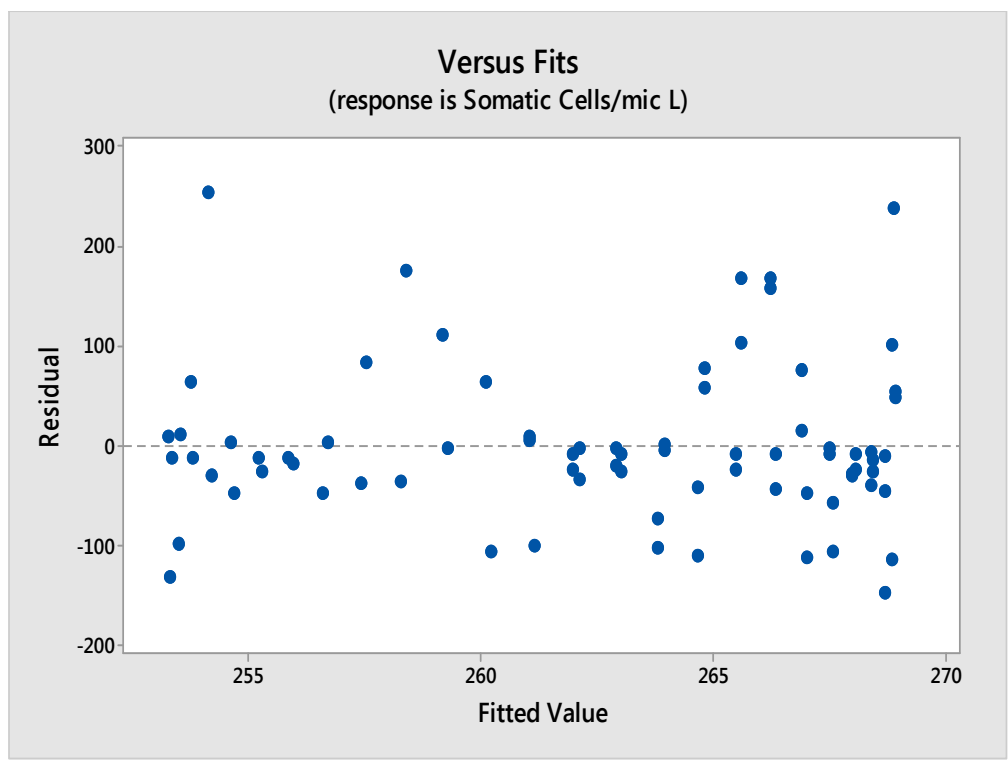




\section{Appendix 3. Temperature Profile in Visalia and Fresno (Central Valley}

California) from 2008 -2009 (Obtained from www.weathersource.com)
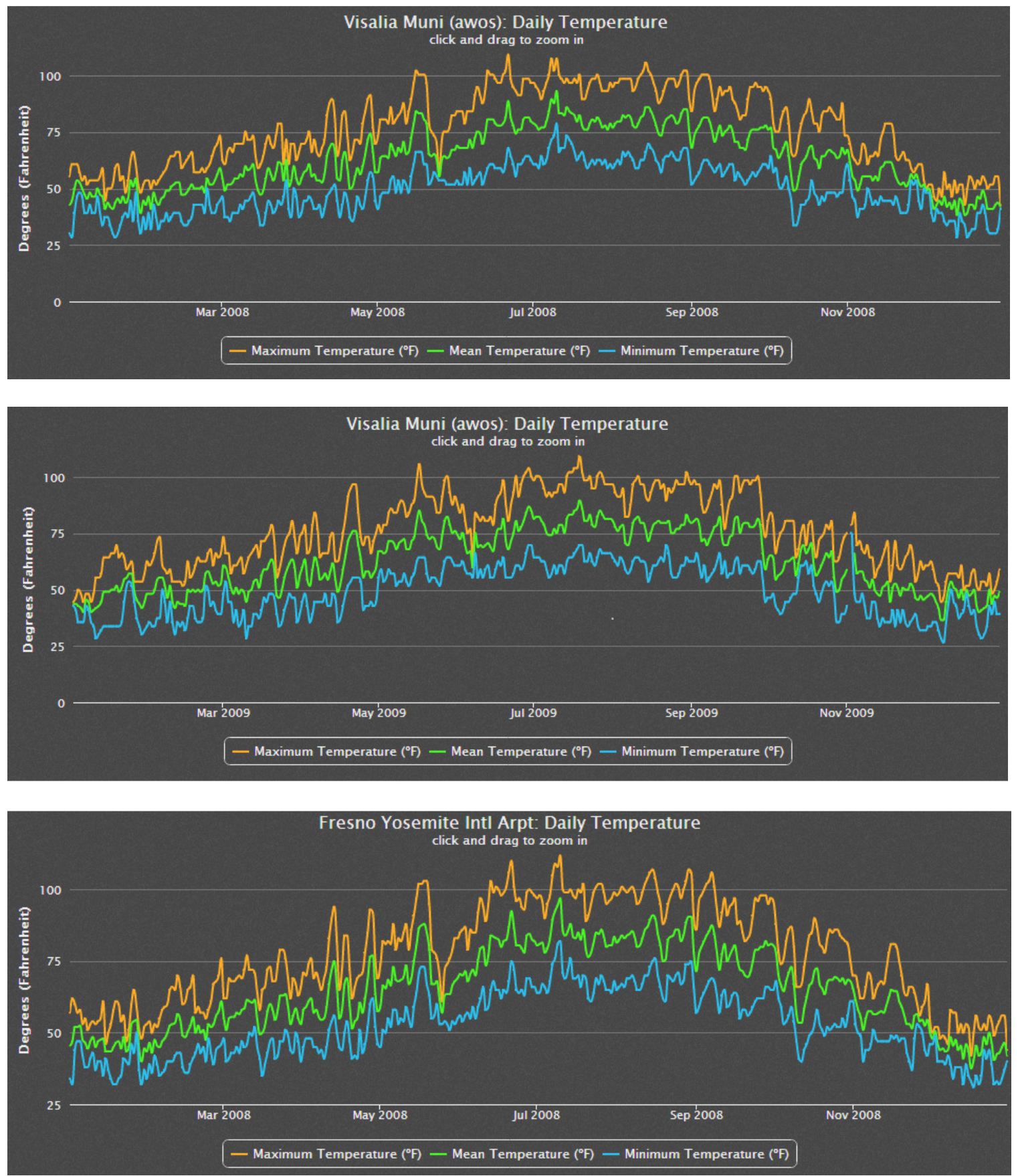


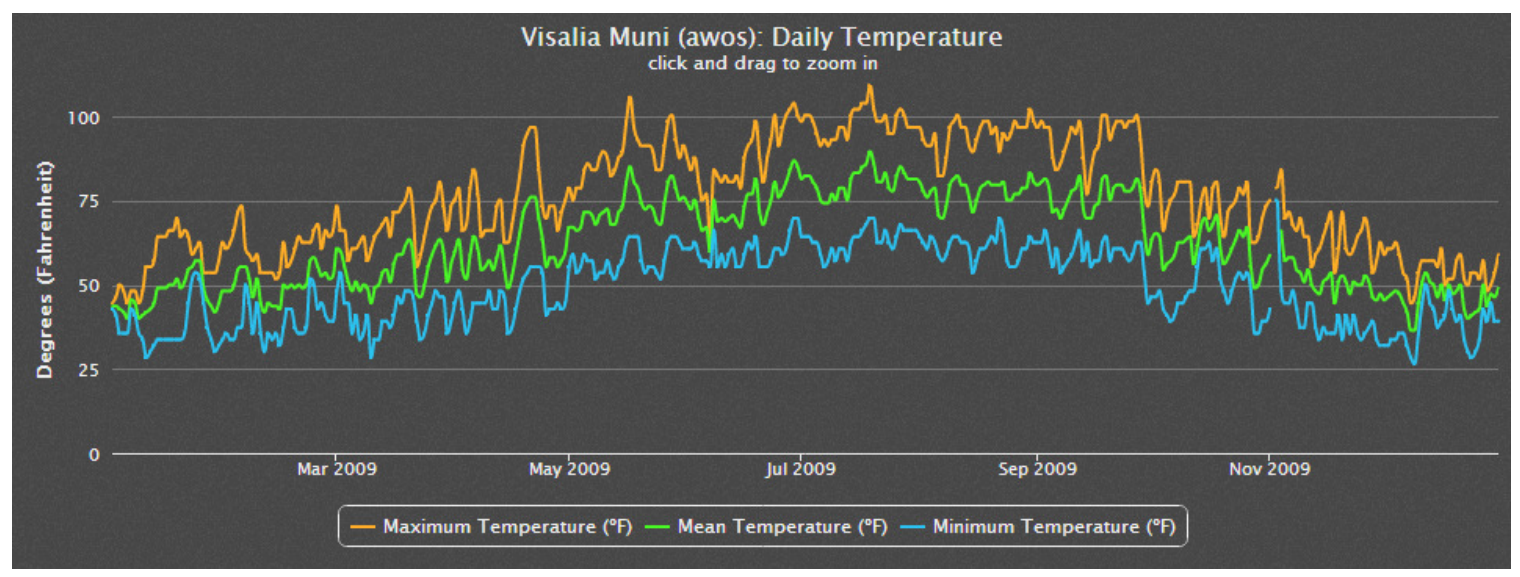


Appendix 4. The precipitation in Visalia and Fresno (Central Valley California) from 2008 -2009 (Obtained from www.weathersource.com)
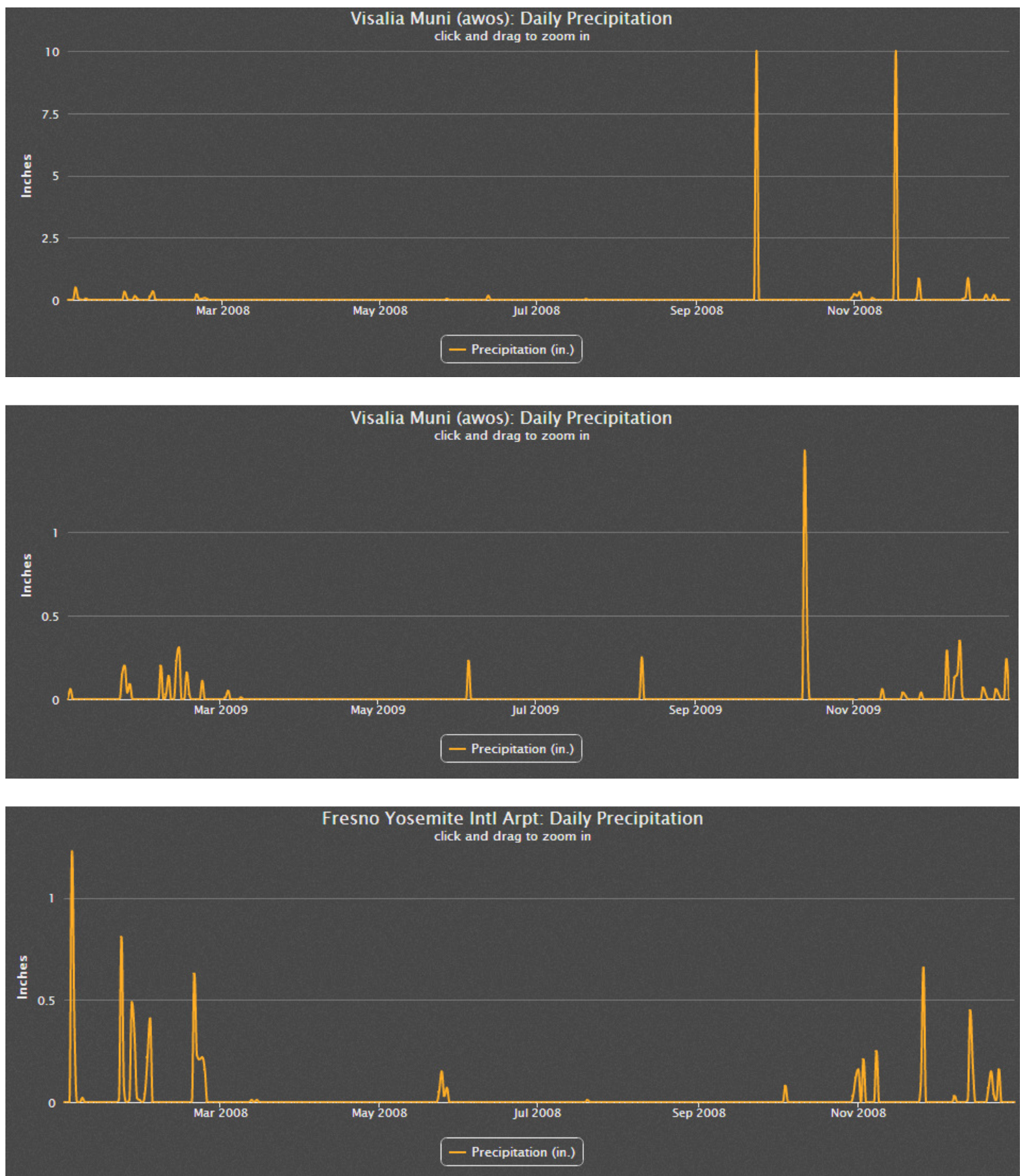


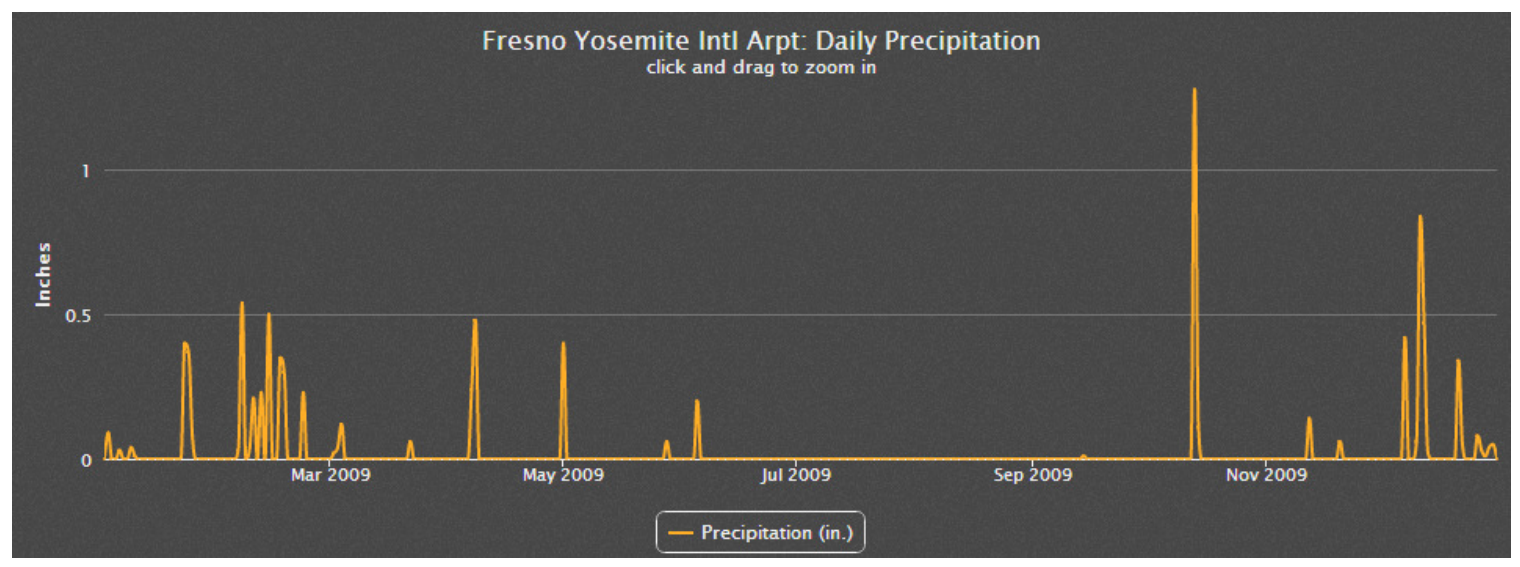


Appendix 5. LMPS Mozzarella Composition after 5 Days of Manufacture (raw data)

\begin{tabular}{|c|c|c|c|c|c|c|c|}
\hline Month & $\begin{array}{l}\text { Sample } \\
\text { Code }\end{array}$ & $\begin{array}{c}\text { Total } \\
\text { Nitrogen } \\
\%\end{array}$ & $\begin{array}{c}\text { Water } \\
\text { Soluble } \\
\text { Nitrogen } \\
\%\end{array}$ & $\begin{array}{c}\text { Total solids } \\
\%\end{array}$ & $\begin{array}{c}\text { Moisture } \\
\%\end{array}$ & Fat \% & $\begin{array}{l}\text { Fat in Dry } \\
\text { Matter \% }\end{array}$ \\
\hline Jul-08 & C080712 & 3.44 & 0.27 & 51.76 & 48.24 & 21.25 & 41.05 \\
\hline Jul-08 & C080726 & 3.49 & 0.27 & 52.02 & 47.98 & 20.50 & 39.41 \\
\hline Aug-08 & C080809 & 3.49 & 0.28 & 51.77 & 48.23 & 21.25 & 41.05 \\
\hline Aug-08 & C080823 & 3.55 & 0.27 & 52.32 & 47.68 & 20.75 & 39.66 \\
\hline Sep-08 & C080906 & 3.61 & 0.32 & 52.03 & 47.97 & 21.65 & 41.61 \\
\hline Sep-08 & C080920 & 3.58 & 0.33 & 51.73 & 48.27 & 22.00 & 42.53 \\
\hline Oct-08 & C0801004 & 3.59 & 0.28 & 52.22 & 47.78 & 22.25 & 42.61 \\
\hline Oct-08 & C0801018 & 3.62 & 0.33 & 52.23 & 47.77 & 21.85 & 41.83 \\
\hline Nov-08 & C0801101 & 3.68 & 0.33 & 52.03 & 47.97 & 21.55 & 41.42 \\
\hline Nov-08 & C0801115 & 3.73 & 0.33 & 52.74 & 47.26 & 21.50 & 40.76 \\
\hline Dec-08 & $\mathrm{C} 0801213$ & 3.73 & 0.33 & 52.59 & 47.41 & 21.48 & 40.84 \\
\hline Dec-08 & C0801227 & 3.79 & 0.33 & 52.99 & 47.01 & 19.58 & 36.94 \\
\hline Jan-09 & C090110 & 3.72 & 0.33 & 51.76 & 48.24 & 20.50 & 39.61 \\
\hline Jan-09 & C090124 & 3.78 & 0.32 & 52.93 & 47.07 & 20.50 & 38.73 \\
\hline Feb-09 & C090207 & 3.71 & 0.31 & 51.62 & 48.38 & 20.25 & 39.23 \\
\hline Feb-09 & C090221 & 3.61 & 0.34 & 51.76 & 48.24 & 22.25 & 42.99 \\
\hline Mar-09 & C090307 & 3.63 & 0.34 & 52.03 & 47.97 & 22.25 & 42.76 \\
\hline Mar-09 & C090321 & 3.63 & 0.36 & 50.37 & 49.63 & 21.50 & 42.68 \\
\hline Apr-09 & C090404 & 3.54 & 0.30 & 52.91 & 47.09 & 21.50 & 40.64 \\
\hline Apr-09 & C090418 & 3.53 & 0.30 & 52.05 & 47.95 & 21.25 & 40.83 \\
\hline May-09 & C090502 & 3.65 & 0.33 & 51.84 & 48.16 & 21.50 & 41.48 \\
\hline Мay-09 & C090516 & 3.50 & 0.38 & 51.73 & 48.27 & 21.80 & 42.14 \\
\hline May-09 & C090530 & 3.45 & 0.38 & 51.25 & 48.75 & 21.89 & 42.71 \\
\hline Jun-09 & C090613 & 3.50 & 0.29 & 52.64 & 47.36 & 22.00 & 41.79 \\
\hline Jun-09 & C090627 & 3.51 & 0.27 & 52.40 & 47.60 & 21.65 & 41.32 \\
\hline Jul-09 & C090711 & 4.30 & 0.30 & 52.59 & 47.41 & 21.25 & 40.41 \\
\hline Jul-09 & C090725 & 4.32 & 0.32 & 52.99 & 47.01 & 21.50 & 40.58 \\
\hline Aug-09 & C090808 & 3.67 & 0.45 & 50.76 & 49.24 & 21.58 & 42.51 \\
\hline Aug-09 & C090823 & 3.88 & 0.35 & 51.93 & 48.07 & 20.75 & 39.96 \\
\hline Sep-09 & C090905 & 3.72 & 0.39 & 51.70 & 48.30 & 22.28 & 43.08 \\
\hline Sep-09 & C090919 & 3.73 & 0.34 & 51.73 & 48.27 & 20.50 & 39.63 \\
\hline Oct-09 & C091005 & 3.82 & 0.36 & 51.76 & 48.24 & 20.50 & 39.61 \\
\hline Oct-09 & C0901031 & 3.78 & 0.31 & 52.30 & 47.70 & 20.25 & 38.72 \\
\hline Nov-09 & C090114 & 3.84 & 0.29 & 52.49 & 47.51 & 22.25 & 42.39 \\
\hline Nov-09 & C0901128 & 3.78 & 0.33 & 50.86 & 49.14 & 21.50 & 42.28 \\
\hline
\end{tabular}




\begin{tabular}{|c|c|c|c|c|c|}
\hline Month & $\begin{array}{c}\text { Sample } \\
\text { Code }\end{array}$ & $\begin{array}{c}\text { Cheese Filtrate } \\
\text { Calcium \% }\end{array}$ & $\begin{array}{c}\text { Total calcium } \\
\text { \% }\end{array}$ & Salt \% & pH \\
\hline Jul-08 & C080712 & na & na & 2.19 & 5.47 \\
\hline Jul-08 & C080726 & na & na & 2.05 & 5.43 \\
\hline Aug-08 & C080809 & 0.283 & 0.57 & 2.235 & 5.43 \\
\hline Aug-08 & C080823 & 0.277 & 0.58 & 2.07 & 5.45 \\
\hline Sep-08 & C080906 & 0.286 & 0.59 & 2.145 & 5.45 \\
\hline Sep-08 & C080920 & 0.255 & 0.61 & 2.235 & 5.41 \\
\hline Oct-08 & C0801004 & 0.286 & 0.58 & 2.095 & 5.54 \\
\hline Oct-08 & C0801018 & 0.270 & 0.59 & 2.06 & 5.49 \\
\hline Nov-08 & C0801101 & 0.266 & 0.59 & 2.005 & 5.43 \\
\hline Nov-08 & C0801115 & 0.249 & 0.62 & 2.125 & 5.50 \\
\hline Dec-08 & C0801213 & 0.241 & 0.60 & 2.03 & 5.51 \\
\hline Dec-08 & C0801227 & 0.256 & 0.63 & 2.135 & 5.47 \\
\hline Jan-09 & C090110 & 0.268 & 0.60 & 2.305 & 5.51 \\
\hline Jan-09 & C090124 & 0.251 & 0.59 & 2.33 & 5.43 \\
\hline Feb-09 & C090207 & 0.248 & 0.58 & 2.19 & 5.51 \\
\hline Feb-09 & C090221 & 0.261 & 0.60 & 2.25 & 5.49 \\
\hline Mar-09 & C090307 & 0.272 & 0.59 & 2.085 & 5.47 \\
\hline Mar-09 & C090321 & 0.246 & 0.61 & 2.055 & 5.51 \\
\hline Apr-09 & C090404 & 0.278 & 0.63 & 1.98 & 5.43 \\
\hline Apr-09 & C090418 & 0.248 & 0.63 & 2.135 & 5.46 \\
\hline May-09 & C090502 & 0.302 & 0.62 & 2.095 & 5.42 \\
\hline May-09 & C090516 & 0.285 & 0.55 & 2.185 & 5.43 \\
\hline May-09 & C090530 & 0.282 & 0.54 & 2.355 & 5.54 \\
\hline Jun-09 & C090613 & 0.289 & 0.53 & 1.88 & 5.48 \\
\hline Jun-09 & C090627 & 0.271 & 0.61 & 2.12 & 5.44 \\
\hline Jul-09 & C090711 & na & 0.59 & 2.235 & 5.45 \\
\hline Jul-09 & C090725 & na & 0.60 & 2.235 & 5.49 \\
\hline Aug-09 & C090808 & 0.260 & 0.61 & 2.15 & 5.45 \\
\hline Aug-09 & C090823 & 0.267 & 0.63 & 2.16 & 5.48 \\
\hline Sep-09 & C090905 & 0.328 & 0.50 & 2.18 & 5.55 \\
\hline Sep-09 & C090919 & 0.279 & 0.58 & 2.215 & 5.51 \\
\hline Oct-09 & C091005 & 0.270 & 0.58 & 2.095 & 5.51 \\
\hline Oct-09 & C0901031 & 0.278 & 0.59 & 2.225 & 5.48 \\
\hline Nov-09 & C090114 & 0.275 & 0.272 & 2.22 & 5.47 \\
\hline Nov-09 & C0901128 & & & 5.43 \\
\hline
\end{tabular}


Appendix 6. LMPS Mozzarella Textural Analysis after 5 Days of Manufacture (raw data)

\begin{tabular}{|c|c|c|c|c|c|}
\hline Month & $\begin{array}{c}\text { Sample } \\
\text { Code }\end{array}$ & $\begin{array}{c}\text { Hardness } \\
\text { (g) }\end{array}$ & Cohesiveness & Springiness & $\begin{array}{c}\text { Chewiness } \\
\text { (g) }\end{array}$ \\
\hline Jul-08 & C080712 & 3088.37 & 0.49 & 0.66 & 1001.54 \\
\hline Jul-08 & C080726 & 3467.30 & 0.52 & 0.66 & 1192.26 \\
\hline Aug-08 & C080809 & 3409.97 & 0.52 & 0.69 & 1213.72 \\
\hline Aug-08 & C080823 & 3741.80 & 0.54 & 0.68 & 1369.04 \\
\hline Sep-08 & C080906 & 3854.83 & 0.56 & 0.70 & 1515.13 \\
\hline Sep-08 & C080920 & 3741.03 & 0.52 & 0.71 & 1366.58 \\
\hline Oct-08 & C0801004 & 3737.33 & 0.53 & 0.70 & 1405.31 \\
\hline Oct-08 & C0801018 & 4299.93 & 0.54 & 0.73 & 1697.88 \\
\hline Nov-08 & C0801101 & 4264.63 & 0.54 & 0.74 & 1707.63 \\
\hline Nov-08 & C0801115 & 4656.63 & 0.56 & 0.75 & 1942.61 \\
\hline Dec-08 & $\mathrm{C} 0801213$ & 4725.17 & 0.56 & 0.73 & 1913.76 \\
\hline Dec-08 & C0801227 & 5353.40 & 0.56 & 0.74 & 2229.54 \\
\hline Jan-09 & C090110 & 4514.60 & 0.57 & 0.72 & 1845.81 \\
\hline Jan-09 & C090124 & 4474.73 & 0.53 & 0.71 & 1663.97 \\
\hline Feb-09 & C090207 & 4212.87 & 0.53 & 0.70 & 1541.58 \\
\hline Feb-09 & C090221 & 3868.03 & 0.51 & 0.69 & 1367.06 \\
\hline Mar-09 & C090307 & 3887.07 & 0.50 & 0.69 & 1342.52 \\
\hline Mar-09 & C090321 & 3973.27 & 0.49 & 0.66 & 1298.46 \\
\hline Apr-09 & C090404 & 3889.67 & 0.46 & 0.65 & 1164.65 \\
\hline Apr-09 & C090418 & 3878.63 & 0.48 & 0.64 & 1208.81 \\
\hline May-09 & C090502 & 3900.53 & 0.48 & 0.63 & 1182.01 \\
\hline Мay-09 & C090516 & 3414.10 & 0.49 & 0.64 & 1066.17 \\
\hline May-09 & C090530 & 3100.07 & 0.48 & 0.58 & 852.41 \\
\hline Jun-09 & C090613 & 3485.43 & 0.50 & 0.61 & 1055.01 \\
\hline Jun-09 & C090627 & 3491.20 & 0.49 & 0.59 & 1014.55 \\
\hline Jul-09 & C090711 & 6354.03 & 0.56 & 0.76 & 2698.35 \\
\hline Jul-09 & C090725 & 4804.40 & 0.50 & 0.73 & 1752.31 \\
\hline Aug-09 & C090808 & 4671.87 & 0.48 & 0.61 & 1373.51 \\
\hline Aug-09 & C090823 & 4394.93 & 0.66 & 0.74 & 2148.13 \\
\hline Sep-09 & C090905 & 4305.70 & 0.43 & 0.58 & 1076.63 \\
\hline Sep-09 & C090919 & 4387.10 & 0.42 & 0.65 & 1193.98 \\
\hline Oct-09 & C091005 & 4449.87 & 0.55 & 0.68 & 1654.94 \\
\hline Oct-09 & C0901031 & 5452.63 & 0.47 & 0.71 & 1801.58 \\
\hline Nov-09 & C090114 & 5502.37 & 0.48 & 0.64 & 1690.39 \\
\hline Nov-09 & C0901128 & 4845.97 & 0.52 & 0.64 & 1605.07 \\
\hline
\end{tabular}




\begin{tabular}{|c|c|c|c|}
\hline Month & $\begin{array}{c}\text { Sample } \\
\text { Code }\end{array}$ & $\begin{array}{c}\text { Aggregation } \\
\text { Index }\end{array}$ & $\begin{array}{c}\text { \% Loss in } \\
\text { shredder }\end{array}$ \\
\hline Jul-08 & C080712 & 6.23 & na \\
\hline Jul-08 & C080726 & 6.02 & na \\
\hline Aug-08 & C080809 & 6.06 & 9.78 \\
\hline Aug-08 & C080823 & 6.07 & 8.66 \\
\hline Sep-08 & C080906 & 5.80 & 9.15 \\
\hline Sep-08 & C080920 & 5.83 & 9.79 \\
\hline Oct-08 & C0801004 & 5.76 & 7.30 \\
\hline Oct-08 & C0801018 & 5.80 & 8.02 \\
\hline Nov-08 & C0801101 & 5.76 & 8.95 \\
\hline Nov-08 & C0801115 & 5.49 & 7.84 \\
\hline Dec-08 & C0801213 & 5.76 & 8.68 \\
\hline Dec-08 & C0801227 & 5.72 & 8.33 \\
\hline Jan-09 & C090110 & 6.04 & 8.18 \\
\hline Jan-09 & C090124 & 5.94 & 8.70 \\
\hline Feb-09 & C090207 & 6.18 & 8.70 \\
\hline Feb-09 & C090221 & 6.29 & 9.09 \\
\hline Mar-09 & C090307 & 6.25 & 10.00 \\
\hline Mar-09 & C090321 & 6.23 & 10.45 \\
\hline Apr-09 & C090404 & 6.35 & 10.87 \\
\hline Apr-09 & C090418 & 6.38 & 10.45 \\
\hline May-09 & C090502 & 5.98 & 11.29 \\
\hline May-09 & C090516 & 6.28 & 11.16 \\
\hline May-09 & C090530 & 6.31 & 12.50 \\
\hline Jun-09 & C090613 & 5.96 & 12.76 \\
\hline Jun-09 & C090627 & 6.28 & 12.12 \\
\hline Jul-09 & C090711 & 6.11 & 8.05 \\
\hline Jul-09 & C090725 & 5.96 & 8.13 \\
\hline Aug-09 & C090808 & 6.01 & 9.33 \\
\hline Aug-09 & C090823 & 6.04 & 9.20 \\
\hline Sep-09 & C090905 & 6.22 & 11.76 \\
\hline Sep-09 & C090919 & 6.04 & 10.71 \\
\hline Oct-09 & C091005 & 5.91 & 9.48 \\
\hline Oct-09 & C0901031 & 5.92 & 9.42 \\
\hline Nov-09 & C090114 & 6.23 & 8.90 \\
\hline Nov-09 & C0901128 & 6.15 & 9.54 \\
\hline
\end{tabular}




\section{Appendix 7. LMPS Mozzarella Textural Analysis after 5 Days of Manufacture}

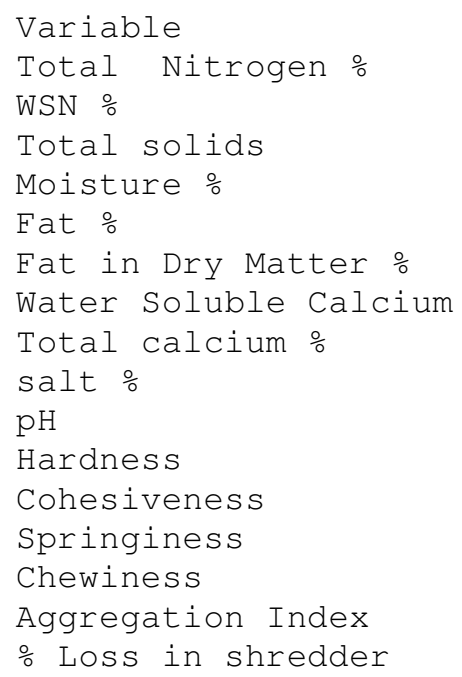

Total
Count
33
33
33
33
33
33
33
33
33
33
33
33
33
33
33
33

StDev
0.1207
0.04006
0.599
0.599
0.707
1.508
0.01814
0.03014
0.1011
0.0381
624
0.04481
0.04877
344.4
0.2192
1.395

Minimum

3.4362

0.26776

50.370

47.012

19.575

36.943

0.24103

0.49764

1.8800

5.4067

3088

0.41887

0.57697

852.4

5.4860

7.303
Maximum

$$
3.8822
$$

0.45318

52.988

49.630

22.275

43.084

0.32846

0.63113

2.3550

5.5533

5502

0.65763

0.74777

2229.5

6.3814

12.759 
Appendix 8. LMPS Mozzarella Ripened at $3.3^{0} \mathrm{C}$ for 21 Days (raw data)

\begin{tabular}{|c|c|c|c|c|c|}
\hline Month & $\begin{array}{c}\text { Sample } \\
\text { Code. }\end{array}$ & $\begin{array}{c}\text { Hardness } \\
\text { (g) }\end{array}$ & Cohesiveness & Springiness & Chewiness (g) \\
\hline Jul-08 & C080712 & 2671.27 & 0.46 & 0.61 & 741.97 \\
\hline Jul-08 & C080726 & 3271.43 & 0.49 & 0.61 & 972.23 \\
\hline Aug-08 & C080809 & 3254.07 & 0.46 & 0.61 & 919.85 \\
\hline Aug-08 & C080823 & 3686.37 & 0.49 & 0.64 & 1157.54 \\
\hline Sep-08 & C080906 & 3756.47 & 0.51 & 0.67 & 1293.32 \\
\hline Sep-08 & C080920 & 3604.07 & 0.47 & 0.67 & 1148.78 \\
\hline Oct-08 & C0801004 & 3566.23 & 0.49 & 0.67 & 1171.34 \\
\hline Oct-08 & C0801018 & 3996.97 & 0.52 & 0.68 & 1408.84 \\
\hline Nov-08 & C0801101 & 3762.07 & 0.51 & 0.68 & 1295.19 \\
\hline Nov-08 & C0801115 & 4329.30 & 0.52 & 0.70 & 1595.41 \\
\hline Dec-08 & $\mathrm{C} 0801213$ & 4687.43 & 0.52 & 0.68 & 1676.98 \\
\hline Dec-08 & $\mathrm{C} 0801227$ & 4820.00 & 0.53 & 0.65 & 1645.23 \\
\hline Jan-09 & C090110 & 4472.33 & 0.52 & 0.66 & 1553.94 \\
\hline Jan-09 & C090124 & 3925.07 & 0.51 & 0.65 & 1304.44 \\
\hline Feb-09 & C090207 & 4038.00 & 0.50 & 0.63 & 1266.62 \\
\hline Feb-09 & C090221 & 3652.17 & 0.49 & 0.65 & 1167.38 \\
\hline Mar-09 & C090307 & 3510.13 & 0.48 & 0.64 & 1066.60 \\
\hline Mar-09 & C090321 & 3706.70 & 0.47 & 0.62 & 1083.97 \\
\hline Apr-09 & C090404 & 3657.10 & 0.46 & 0.61 & 1023.16 \\
\hline Apr-09 & C090418 & 3638.47 & 0.45 & 0.61 & 1008.85 \\
\hline May-09 & C090502 & 3584.07 & 0.46 & 0.58 & 958.77 \\
\hline May-09 & C090516 & 3182.30 & 0.47 & 0.61 & 900.63 \\
\hline May-09 & C090530 & 2770.57 & 0.46 & 0.57 & 735.26 \\
\hline Jun-09 & C090613 & 3270.23 & 0.49 & 0.56 & 900.84 \\
\hline Jun-09 & C090627 & 3016.77 & 0.46 & 0.56 & 773.76 \\
\hline Jul-09 & C090711 & 5355.60 & 0.47 & 0.69 & 1736.13 \\
\hline Jul-09 & C090725 & 4600.87 & 0.46 & 0.68 & 1439.11 \\
\hline Aug-09 & C090808 & 4257.33 & 0.46 & 0.61 & 1205.20 \\
\hline Aug-09 & C090823 & 3790.33 & 0.42 & 0.58 & 926.94 \\
\hline Sep-09 & C090905 & 3627.80 & 0.47 & 0.61 & 1029.67 \\
\hline Sep-09 & C090919 & 3193.73 & 0.45 & 0.59 & 839.16 \\
\hline Oct-09 & C091005 & 3902.07 & 0.48 & 0.64 & 1186.32 \\
\hline Oct-09 & C0901031 & 4490.97 & 0.55 & 0.61 & 1487.22 \\
\hline Nov-09 & C090114 & 4489.00 & 0.45 & 0.63 & 1258.65 \\
\hline Nov-09 & C0901128 & 4589.00 & 0.46 & 0.63 & 1309.71 \\
\hline
\end{tabular}




\begin{tabular}{|c|c|c|c|c|c|}
\hline Month & $\begin{array}{l}\text { Sample } \\
\text { Code }\end{array}$ & WSN \% & $\begin{array}{l}\text { Aggregation } \\
\text { index }\end{array}$ & $\begin{array}{l}\% \text { Loss in } \\
\text { shredder }\end{array}$ & pH \\
\hline Jul-08 & C080712 & 0.31 & 6.39 & na & 5.58 \\
\hline Jul-08 & $\mathrm{C} 080726$ & 0.35 & 6.17 & 14.89 & 5.65 \\
\hline Aug-08 & C080809 & 0.38 & 6.17 & 10.37 & 5.66 \\
\hline Aug-08 & $\mathrm{C} 080823$ & 0.33 & 6.11 & 11.85 & 5.47 \\
\hline Sep-08 & C080906 & 0.41 & 5.81 & 11.26 & 5.51 \\
\hline Sep-08 & $\mathrm{C} 080920$ & 0.36 & 6.15 & 16.73 & 5.44 \\
\hline Oct-08 & C0801004 & 0.45 & 5.92 & 9.91 & 5.56 \\
\hline Oct-08 & $\mathrm{C} 0801018$ & 0.37 & 5.91 & 10.68 & 5.49 \\
\hline Nov-08 & $\mathrm{C} 0801101$ & 0.45 & 5.84 & 10.08 & 5.55 \\
\hline Nov-08 & $\mathrm{C} 0801115$ & 0.40 & 5.95 & 10.05 & 5.55 \\
\hline Dec-08 & $\mathrm{C} 0801213$ & 0.42 & 5.91 & 10.00 & 5.51 \\
\hline Dec-08 & C0801227 & 0.42 & 5.84 & 10.48 & 5.51 \\
\hline Jan-09 & C090110 & 0.40 & 6.11 & 9.52 & 5.44 \\
\hline Jan-09 & C090124 & 0.34 & 6.20 & 10.00 & 5.51 \\
\hline Feb-09 & C090207 & 0.34 & 6.22 & 11.36 & 5.55 \\
\hline Feb-09 & C090221 & 0.36 & 6.33 & 12.40 & 5.48 \\
\hline Mar-09 & C090307 & 0.37 & 6.39 & 13.50 & 5.52 \\
\hline Mar-09 & C090321 & 0.39 & 6.35 & 13.04 & 5.44 \\
\hline Apr-09 & C090404 & 0.37 & 6.33 & 12.30 & 5.54 \\
\hline Apr-09 & C090418 & 0.41 & 6.41 & 12.50 & 5.49 \\
\hline May-09 & C090502 & na & 6.22 & 13.18 & 5.54 \\
\hline Мay-09 & C090516 & na & 6.32 & 13.16 & 5.54 \\
\hline May-09 & C090530 & 0.51 & 6.12 & 16.00 & 5.55 \\
\hline Jun-09 & C090613 & 0.39 & 6.19 & 14.44 & 5.63 \\
\hline Jun-09 & C090627 & 0.39 & 6.01 & 14.29 & 5.53 \\
\hline Jul-09 & C090711 & 0.33 & 6.12 & 12.12 & 5.48 \\
\hline Jul-09 & C090725 & 0.42 & 6.19 & 12.90 & 5.49 \\
\hline Aug-09 & C090808 & na & 6.18 & 15.46 & 5.55 \\
\hline Aug-09 & C090823 & 0.43 & 6.13 & 13.04 & 5.49 \\
\hline Sep-09 & C090905 & 0.43 & 6.28 & 16.67 & 5.54 \\
\hline Sep-09 & C090919 & 0.38 & 6.25 & 15.49 & 5.55 \\
\hline Oct-09 & $\mathrm{C} 091005$ & 0.39 & 6.09 & 13.85 & 5.57 \\
\hline Oct-09 & C0901031 & 0.35 & 6.29 & 12.31 & 5.49 \\
\hline Nov-09 & C090114 & 0.34 & 6.22 & 12.50 & 5.54 \\
\hline Nov-09 & C0901128 & 0.35 & 6.21 & 14.29 & 5.52 \\
\hline
\end{tabular}


Appendix 9. LMPS Mozzarella Ripened at $8.9^{\circ} \mathrm{C}$ for 21 Days (raw data)

\begin{tabular}{|c|c|c|c|c|c|}
\hline Month & $\begin{array}{c}\text { Sample } \\
\text { code. }\end{array}$ & $\begin{array}{c}\text { Hardness } \\
\text { (g) }\end{array}$ & Cohesiveness & Springiness & $\begin{array}{c}\text { Chewiness } \\
\text { (g) }\end{array}$ \\
\hline Jul-08 & C080712 & 2593.83 & 0.47 & 0.60 & 730.10 \\
\hline Jul-08 & $\mathrm{C} 080726$ & 3183.17 & 0.49 & 0.61 & 937.90 \\
\hline Aug-08 & C080809 & 3160.07 & 0.46 & 0.61 & 897.06 \\
\hline Aug-08 & C080823 & 3593.87 & 0.47 & 0.64 & 1094.41 \\
\hline Sep-08 & C080906 & 3534.53 & 0.50 & 0.66 & 1176.51 \\
\hline Sep-08 & $\mathrm{C} 080920$ & 3570.10 & 0.46 & 0.66 & 1084.51 \\
\hline Oct-08 & C0801004 & 3470.80 & 0.49 & 0.67 & 1145.13 \\
\hline Oct-08 & $\mathrm{C} 0801018$ & 3753.67 & 0.52 & 0.67 & 1320.81 \\
\hline Nov-08 & C0801101 & 3570.57 & 0.49 & 0.67 & 1188.87 \\
\hline Nov-08 & $\mathrm{C} 0801115$ & 4210.83 & 0.52 & 0.69 & 1520.96 \\
\hline Dec-08 & C0801213 & 4477.47 & 0.52 & 0.67 & 1563.59 \\
\hline Dec-08 & C0801227 & 4449.43 & 0.51 & 0.66 & 1496.23 \\
\hline Jan-09 & C090110 & 4330.53 & 0.53 & 0.65 & 1483.13 \\
\hline Jan-09 & C090124 & 3777.23 & 0.50 & 0.65 & 1223.81 \\
\hline Feb-09 & C090207 & 3734.13 & 0.48 & 0.64 & 1149.22 \\
\hline Feb-09 & C090221 & 3563.63 & 0.51 & 0.65 & 1166.79 \\
\hline Mar-09 & C090307 & 3421.73 & 0.46 & 0.63 & 994.77 \\
\hline Mar-09 & C090321 & 3448.57 & 0.46 & 0.62 & 994.24 \\
\hline Apr-09 & C090404 & 3447.20 & 0.42 & 0.61 & 886.07 \\
\hline Apr-09 & C090418 & 3549.43 & 0.46 & 0.62 & 1011.90 \\
\hline Мay-09 & C090502 & 3275.10 & 0.45 & 0.58 & 854.92 \\
\hline May-09 & C090516 & 2860.30 & 0.46 & 0.60 & 801.32 \\
\hline Мay-09 & C090530 & 2522.60 & 0.46 & 0.57 & 663.30 \\
\hline Jun-09 & C090613 & 2887.67 & 0.47 & 0.56 & 761.33 \\
\hline Jun-09 & C090627 & 2849.77 & 0.46 & 0.54 & 711.81 \\
\hline Jul-09 & C090711 & 5135.37 & 0.47 & 0.65 & 1559.93 \\
\hline Jul-09 & C090725 & 4352.30 & 0.46 & 0.65 & 1296.96 \\
\hline Aug-09 & C090808 & 4083.50 & 0.44 & 0.60 & 1078.40 \\
\hline Aug-09 & C090823 & 3600.67 & 0.44 & 0.59 & 944.43 \\
\hline Sep-09 & C090905 & 2585.87 & 0.49 & 0.60 & 751.24 \\
\hline Sep-09 & C090919 & 2888.70 & 0.46 & 0.61 & 821.89 \\
\hline Oct-09 & C091005 & 3290.07 & 0.50 & 0.62 & 1023.53 \\
\hline Oct-09 & C0901031 & 4496.63 & 0.42 & 0.66 & 1253.72 \\
\hline Nov-09 & C090114 & 4620.19 & 0.44 & 0.62 & 1261.15 \\
\hline Nov-09 & $\mathrm{C} 0901128$ & 4586.85 & 0.45 & 0.61 & 1260.58 \\
\hline
\end{tabular}




\begin{tabular}{|c|c|c|c|c|c|}
\hline Month & $\begin{array}{c}\text { Sample } \\
\text { Code. }\end{array}$ & WSN \% & $\begin{array}{l}\text { Aggregation } \\
\text { index }\end{array}$ & $\begin{array}{l}\% \text { Loss } \\
\text { in } \\
\text { shredder }\end{array}$ & pH \\
\hline Jul-08 & C080712 & 0.37 & 6.32 & 15.24 & na \\
\hline Jul-08 & C080726 & 0.41 & 6.20 & 11.32 & 5.52 \\
\hline Aug-08 & C080809 & 0.38 & 6.21 & 14.33 & na \\
\hline Aug-08 & $\mathrm{C} 080823$ & 0.36 & 6.12 & 13.65 & 5.52 \\
\hline Sep-08 & C080906 & 0.41 & 5.88 & 17.05 & 5.49 \\
\hline Sep-08 & $\mathrm{C} 080920$ & 0.38 & 6.19 & 11.59 & na \\
\hline Oct-08 & $\mathrm{C} 0801004$ & 0.50 & 6.07 & 12.99 & 5.60 \\
\hline Oct-08 & $\mathrm{C} 0801018$ & 0.44 & 6.00 & 12.62 & 5.49 \\
\hline Nov-08 & $\mathrm{C} 0801101$ & 0.47 & 5.81 & 12.62 & 5.52 \\
\hline Nov-08 & $\mathrm{C} 0801115$ & 0.43 & 6.04 & na & 5.58 \\
\hline Dec-08 & $\mathrm{C} 0801213$ & 0.45 & 5.92 & 11.30 & 5.52 \\
\hline Dec-08 & $\mathrm{C} 0801227$ & 0.44 & 5.88 & 12.50 & 5.49 \\
\hline Jan-09 & $\mathrm{C} 090110$ & 0.42 & 6.14 & 12.27 & 5.43 \\
\hline Jan-09 & C090124 & 0.37 & 6.06 & 13.18 & 5.52 \\
\hline Feb-09 & C090207 & 0.39 & 6.23 & 14.29 & 5.57 \\
\hline Feb-09 & C090221 & 0.37 & 6.25 & 15.50 & 5.50 \\
\hline Mar-09 & C090307 & 0.42 & 6.43 & 12.50 & 5.50 \\
\hline Mar-09 & C090321 & 0.42 & 6.42 & 14.47 & 5.43 \\
\hline Apr-09 & C090404 & 0.38 & 6.38 & 17.86 & 5.53 \\
\hline Apr-09 & C090418 & 0.43 & 6.46 & 15.42 & 5.52 \\
\hline May-09 & C090502 & na & 6.26 & 15.95 & 5.43 \\
\hline May-09 & C090516 & na & 6.34 & 17.91 & 5.55 \\
\hline May-09 & C090530 & 0.52 & 6.23 & 17.24 & 5.60 \\
\hline Jun-09 & C090613 & 0.41 & 6.23 & 15.15 & 5.57 \\
\hline Jun-09 & C090627 & 0.42 & 6.12 & 12.60 & 5.51 \\
\hline Jul-09 & C090711 & 0.40 & 6.23 & 13.79 & 5.49 \\
\hline Jul-09 & $\mathrm{C} 090725$ & 0.51 & 6.23 & 17.91 & 5.48 \\
\hline Aug-09 & C090808 & na & 6.18 & 14.53 & 5.56 \\
\hline Aug-09 & C090823 & 0.44 & 6.27 & 18.97 & 5.50 \\
\hline Sep-09 & C090905 & 0.47 & 6.30 & 13.51 & 5.56 \\
\hline Sep-09 & C090919 & 0.39 & 6.25 & 17.65 & 5.57 \\
\hline Oct-09 & $\mathrm{C} 091005$ & 0.39 & 6.19 & 12.68 & 5.57 \\
\hline Oct-09 & $\mathrm{C} 0901031$ & 0.37 & 6.24 & 10.53 & 5.51 \\
\hline Nov-09 & C090114 & 0.34 & 6.17 & 12.50 & 5.52 \\
\hline Nov-09 & $\mathrm{C} 0901128$ & na & 6.27 & na & 5.53 \\
\hline
\end{tabular}




\section{Appendix 10. Statistical Analysis of 21 days Ripened LMPS Mozzarella}

\section{Descriptive Statistics of Cheese Parameters when Ripened at $3.3^{\circ} \mathrm{C}$}

\begin{tabular}{|c|c|c|c|c|c|c|c|}
\hline Variable & $\mathrm{N}$ & $\mathrm{N}^{*}$ & Mean & SE Mean & StDev & Minimum & Q1 \\
\hline Hardness 38 F & 33 & 0 & 3760.1 & 95.0 & 545.5 & 2593.8 & 3390.8 \\
\hline Cohesiveness $38 \mathrm{~F}$ & 33 & 0 & 0.48254 & 0.00514 & 0.02953 & 0.41835 & 0.45943 \\
\hline Springiness $38 \mathrm{~F}$ & 33 & 0 & 0.62767 & 0.00636 & 0.03655 & 0.56313 & 0.60702 \\
\hline Chewiness $38 \mathrm{~F}$ & 33 & 0 & 1151.9 & 44.8 & 257.4 & 735.3 & 942.9 \\
\hline$\%$ Loss in shredder $38 \mathrm{~F}$ & 32 & 1 & 12.675 & 0.375 & 2.123 & 9.524 & 10.527 \\
\hline Aggregation index 38 F & 32 & 1 & 6.1444 & 0.0294 & 0.1663 & 5.8124 & 6.0324 \\
\hline WSN $\div 38 \mathrm{~F}$ & 30 & 3 & 0.38052 & 0.00644 & 0.03526 & 0.31320 & 0.35134 \\
\hline $\mathrm{pH} 38 \mathrm{~F}$ & 33 & 0 & 5.5294 & 0.00924 & 0.0531 & 5.4367 & 5.4883 \\
\hline Variable & & dian & 23 & Maximum & & & \\
\hline Hardness $38 \mathrm{~F}$ & & 86.4 & 4147.7 & 4820.0 & & & \\
\hline Cohesiveness $38 \mathrm{~F}$ & & 47625 & 0.51014 & 0.54631 & & & \\
\hline Springiness $38 \mathrm{~F}$ & & 62533 & 0.65735 & 0.70273 & & & \\
\hline Chewiness $38 \mathrm{~F}$ & & 57.5 & 1299.8 & 1677.0 & & & \\
\hline \% Loss in shredder $38 \mathrm{~F}$ & & .500 & 14.286 & 16.735 & & & \\
\hline Aggregation index $38 \mathrm{~F}$ & & 1768 & 6.2705 & 6.3893 & & & \\
\hline WSN $\div 38 \mathrm{~F}$ & & 37722 & 0.40792 & 0.45073 & & & \\
\hline $\mathrm{pH} \quad 38 \quad \mathrm{~F}$ & 5. & 5367 & 5.5533 & 5.6600 & & & \\
\hline
\end{tabular}

\section{Descriptive Statistics of Cheese Parameters when Ripened at $8.9^{\circ} \mathrm{C}$}

\begin{tabular}{|c|c|c|c|c|c|c|c|}
\hline Variable & $\mathrm{N}$ & $\mathrm{N}^{\star}$ & Mean & SE Mean & StDev & Minimum & Q1 \\
\hline Hardness 48 F & 33 & 0 & 3557 & 104 & 598 & 2523 & 3172 \\
\hline Cohesiveness $48 \mathrm{~F}$ & 33 & 0 & 0.47558 & 0.00505 & 0.02898 & 0.42096 & 0.45897 \\
\hline Chewiness $48 \mathrm{~F}$ & 33 & 0 & 1068.3 & 42.9 & 246.2 & 663.3 & 870.5 \\
\hline Springiness $48 \mathrm{~F}$ & 33 & 0 & 0.62596 & 0.00622 & 0.03572 & 0.54463 & 0.60365 \\
\hline$\circ$ Loss in shredder $48 \mathrm{~F}$ & 31 & 2 & 14.191 & 0.402 & 2.236 & 10.526 & 12.500 \\
\hline Aggregation index 48 F & 33 & 0 & 6.1838 & 0.0277 & 0.1591 & 5.8126 & 6.0948 \\
\hline WSN $\frac{\circ}{0} 48 \mathrm{~F}$ & 29 & 4 & 0.40944 & 0.00706 & 0.03802 & 0.33658 & 0.37660 \\
\hline $\mathrm{pH} \quad 48 \mathrm{~F}$ & 30 & 3 & 5.5238 & 0.00808 & 0.0443 & 5.4300 & 5.5025 \\
\hline Variable & $\mathrm{Me}$ & dian & Q3 & Maximum & & & \\
\hline Hardness $48 \mathrm{~F}$ & 35 & & 3930 & 4620 & & & \\
\hline Cohesiveness $48 \mathrm{~F}$ & & 6725 & 0.49824 & 0.52528 & & & \\
\hline Chewiness $48 \mathrm{~F}$ & & 78.4 & 1238.8 & 1563.6 & & & \\
\hline Springiness $48 \mathrm{~F}$ & & 2337 & 0.65620 & 0.69350 & & & \\
\hline Loss in shredder $48 \mathrm{~F}$ & & 650 & 15.500 & 18.966 & & & \\
\hline Aggregation index $48 \mathrm{~F}$ & & 113 & 6.2695 & 6.4564 & & & \\
\hline WSN $\div 48 \mathrm{~F}$ & & 1392 & 0.43298 & 0.49821 & & & \\
\hline $\mathrm{pH} \quad 48 \quad \mathrm{~F}$ & & 200 & 5.5617 & 5.6033 & & & \\
\hline
\end{tabular}




\section{Paired t-tests between Cheese Parameters when Ripened at $3.3^{\circ} \mathrm{C}(38 \mathrm{~F})$ and $8.9^{\circ} \mathrm{C}(48 \mathrm{~F})$}

\section{Water Soluble Nitrogen(WSN \%) when Ripened at $3.3^{\circ} \mathrm{C}(38 F)$ and $8.9^{\circ} \mathrm{C}(48 F)$}
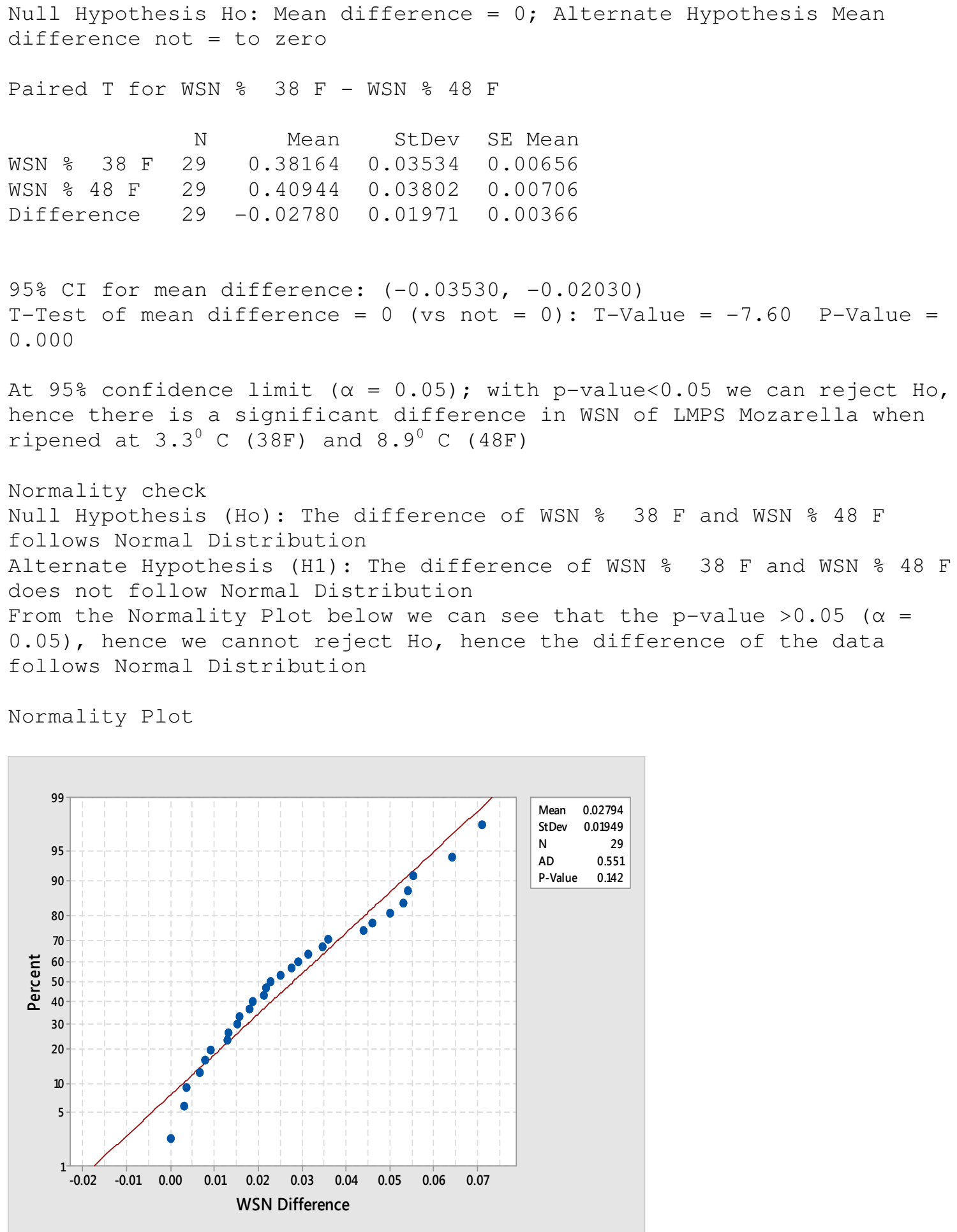


\section{Hardness when Ripened at $3.3^{\circ} \mathrm{C}(38 F)$ and $8.9^{\circ} \mathrm{C}(48 F)$}

Null Hypothesis Ho: Mean difference $=0$; Alternate Hypothesis Mean difference not $=$ to zero

$\begin{array}{lrrrrr} & & N & \text { Mean } & \text { StDev } & \text { SE } \\ \text { Hardness } 38 \text { F } & 33 & 3760 & 545 & 95 \\ \text { Hardness 48 F } & 33 & 3557 & 598 & 104 \\ \text { Difference } & & 33 & 202.8 & 203.2 & 35.4\end{array}$

95\% CI for mean difference: (130.8, 274.9)

$\mathrm{T}$-Test of mean difference $=0(\mathrm{vs}$ not $=0): \mathrm{T}$-Value $=5.73 \quad \mathrm{P}$-Value $=$ 0.000

At 95\% confidence limit ( $\alpha=0.05)$; with $p$-value<0.05 we can reject Ho, hence there is a significant difference in hardenss of LMPS Mozarella when ripened at $3.3^{\circ} \mathrm{C}(38 \mathrm{~F})$ and $8.9^{\circ} \mathrm{C}(48 \mathrm{~F})$

Normality Check

Null Hypothesis (Ho): The difference of Hardness 38 F and Hardness 48 F follows Normal Distribution

Alternate Hypothesis (H1): The difference of WSN $\% 38$ F and WSN 48 F does not follow Normal Distribution

From the Normality Plot below we can see that the p-value $>0.05(\alpha=$ $0.05)$, hence we cannot reject Ho, hence the difference of the data

follows Normal Distribution

Normality Plot

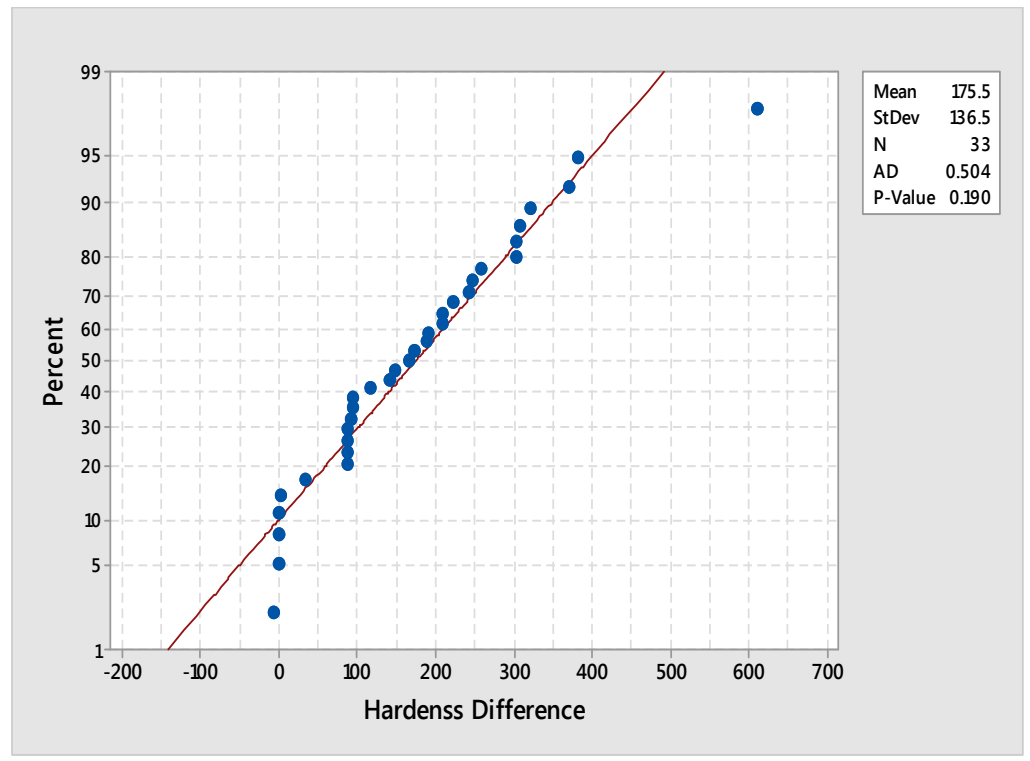




\section{Cohesiveness when Ripened at $3.3^{\circ} \mathrm{C}(38 \mathrm{~F})$ and $8.9^{\circ} \mathrm{C}(48 \mathrm{~F})$}
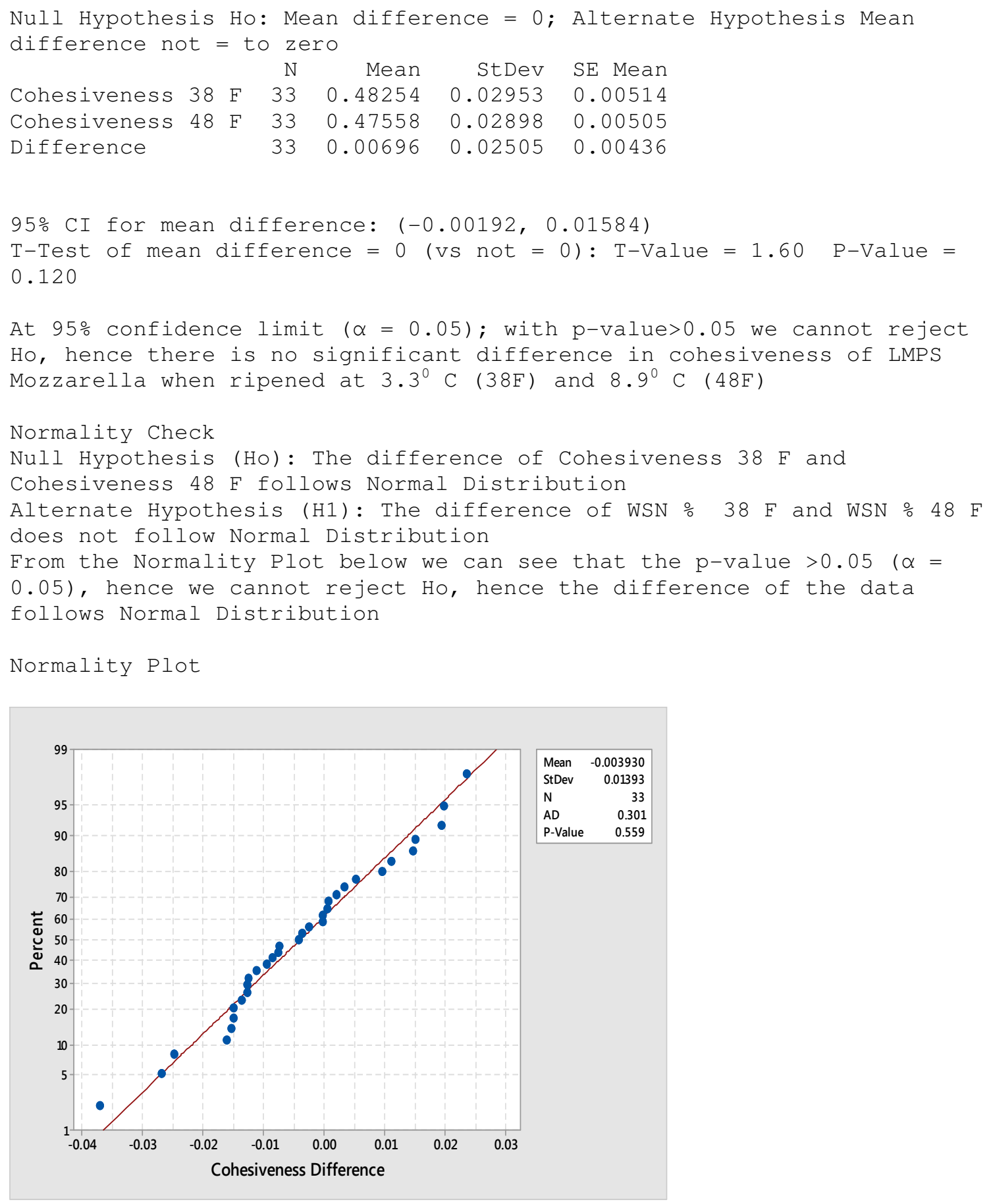


\section{Springiness when Ripened at $3.3^{\circ} \mathrm{C}(38 \mathrm{~F})$ and $8.9^{\circ} \mathrm{C}(48 \mathrm{~F})$}

Null Hypothesis Ho: Mean difference $=0$; Alternate Hypothesis Mean difference not $=$ to zero
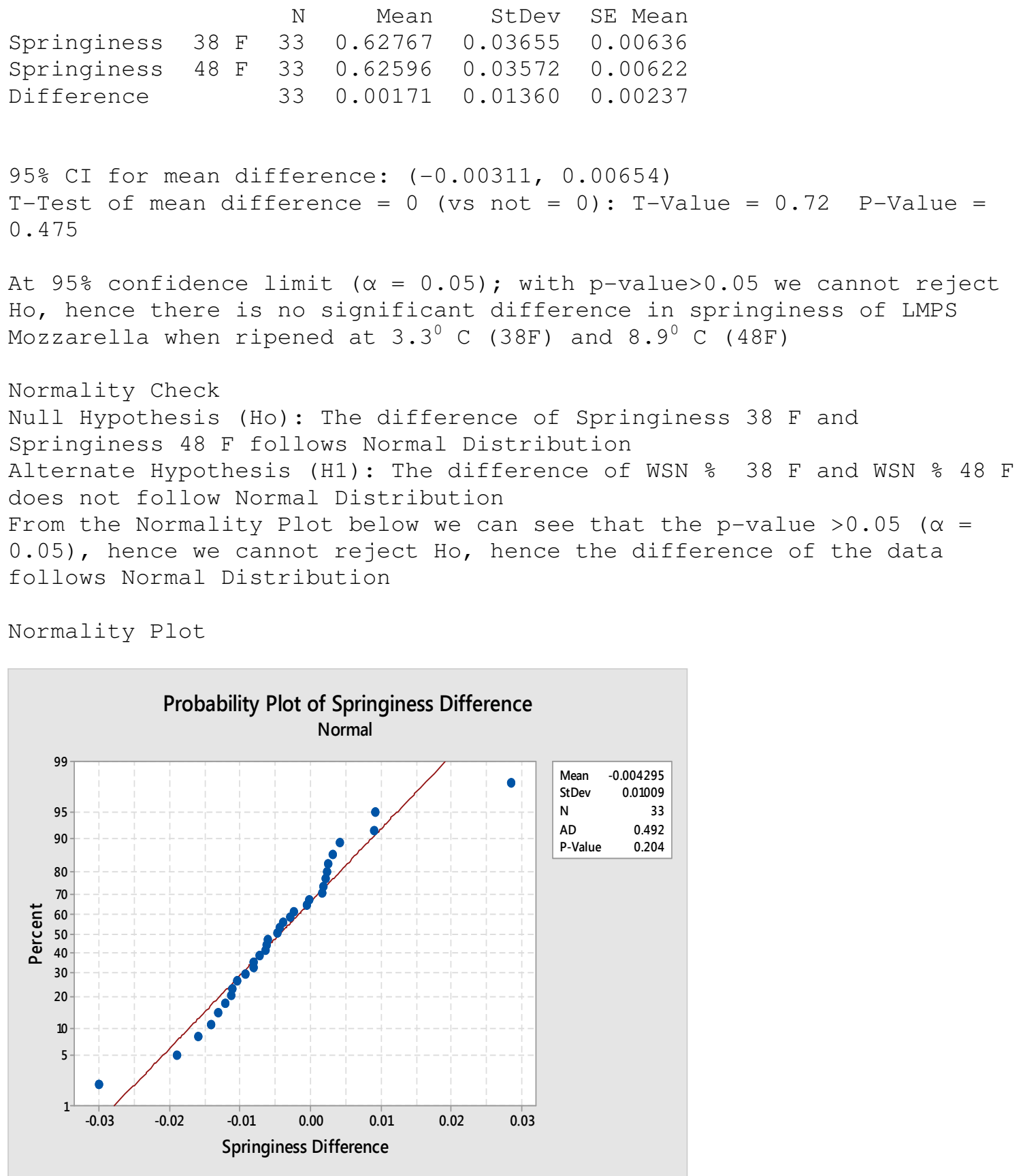


\section{Chewiness when Ripened at $3.3^{\circ} \mathrm{C}(38 \mathrm{~F})$ and $8.9^{\circ} \mathrm{C}(48 \mathrm{~F})$}

Null Hypothesis Ho: Mean difference $=0$; Alternate Hypothesis Mean difference not $=$ to zero

\begin{tabular}{|c|c|c|c|c|c|c|c|}
\hline & & & $\mathrm{N}$ & Mean & StDev & $\mathrm{SE}$ & Mean \\
\hline Chewiness & 38 & F & 33 & 1151.9 & 257.4 & & \\
\hline Chewiness & 48 & $\mathrm{~F}$ & 33 & 1068.3 & 246.2 & & \\
\hline ifferenc & & & 33 & 83.6 & 65.5 & & \\
\hline
\end{tabular}

95 CI for mean difference: (60.4, 106.9)

$\mathrm{T}$-Test of mean difference $=0$ (vs not $=0): \mathrm{T}$-Value $=7.34$ P-Value $=$ 0.000

At 95\% confidence limit $(\alpha=0.05)$; with p-value<0.05 we can reject Ho, hence there is a significant difference in chewiness of LMPS Mozzarella when ripened at $3.3^{\circ} \mathrm{C}(38 \mathrm{~F})$ and $8.9^{\circ} \mathrm{C}(48 \mathrm{~F})$

Normality Check

Null Hypothesis (Ho): The difference of Chewiness 38 F and Chewiness 48 F follows Normal Distribution

Alternate Hypothesis (H1): The difference of WSN $\div 38$ F and WSN $\div 8$ F does not follow Normal Distribution

From the Normality Plot below we can see that the p-value $>0.05(\alpha=$ $0.05)$, hence we cannot reject Ho, hence the difference of the data follows Normal Distribution

Normality Plot

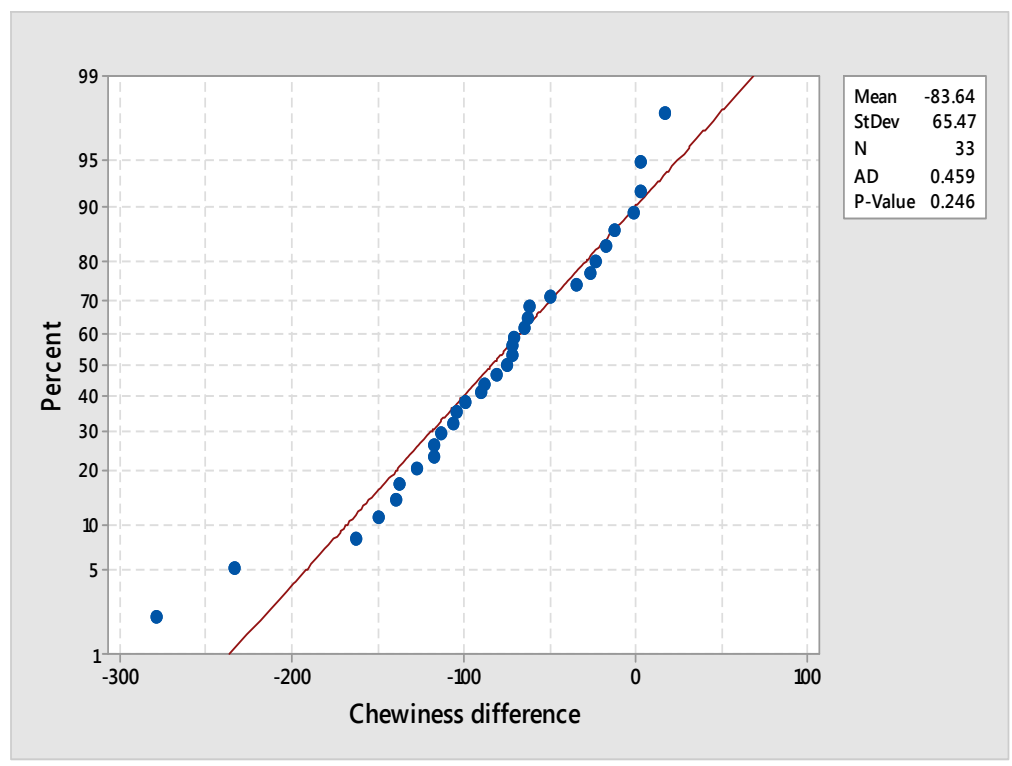




\section{Aggregation index when Ripened at $3.3^{\circ} \mathrm{C}(38 \mathrm{~F})$ and $8.9^{\circ} \mathrm{C}(48 \mathrm{~F})$}

Null Hypothesis Ho: Mean difference $=0$; Alternate Hypothesis Mean difference not $=$ to zero

$\begin{array}{lllrrrr} & & & & \text { Mean } & \text { StDev } & \text { SE Mean } \\ \text { Aggregation index } & 38 & \mathrm{~F} & 32 & 6.1444 & 0.1663 & 0.0294 \\ \text { Aggregation index } 48 & \mathrm{~F} & 32 & 6.1753 & 0.1538 & 0.0272 \\ \text { Difference } & & & 32 & -0.0309 & 0.0632 & 0.0112\end{array}$

95\% CI for mean difference: (-0.0537, -0.0081)

$\mathrm{T}$-Test of mean difference $=0$ (vs not $=0$ ): $\mathrm{T}$-Value $=-2.77$ P-Value $=$ 0.009

At 95\% confidence limit $(\alpha=0.05)$; with $p-v a l u e<0.05$ we can reject Ho, hence there is a significant difference in aggregation of LMPS

Mozzarella when ripened at $3.3^{\circ} \mathrm{C}(38 \mathrm{~F})$ and $8.9^{\circ} \mathrm{C}(48 \mathrm{~F})$

Normality Check

Null Hypothesis (Ho): The difference of Aggregation index $38 \mathrm{~F}$ and Aggregation index $48 \mathrm{~F}$ follows Normal Distribution Alternate Hypothesis (H1): The difference of WSN $\% 38$ F and WSN 48 F does not follow Normal Distribution

From the Normality Plot below we can see that the p-value $>0.05$ ( $\alpha=$ 0.05), hence we cannot reject Ho, hence the difference of the data follows Normal Distribution

Normality Plot

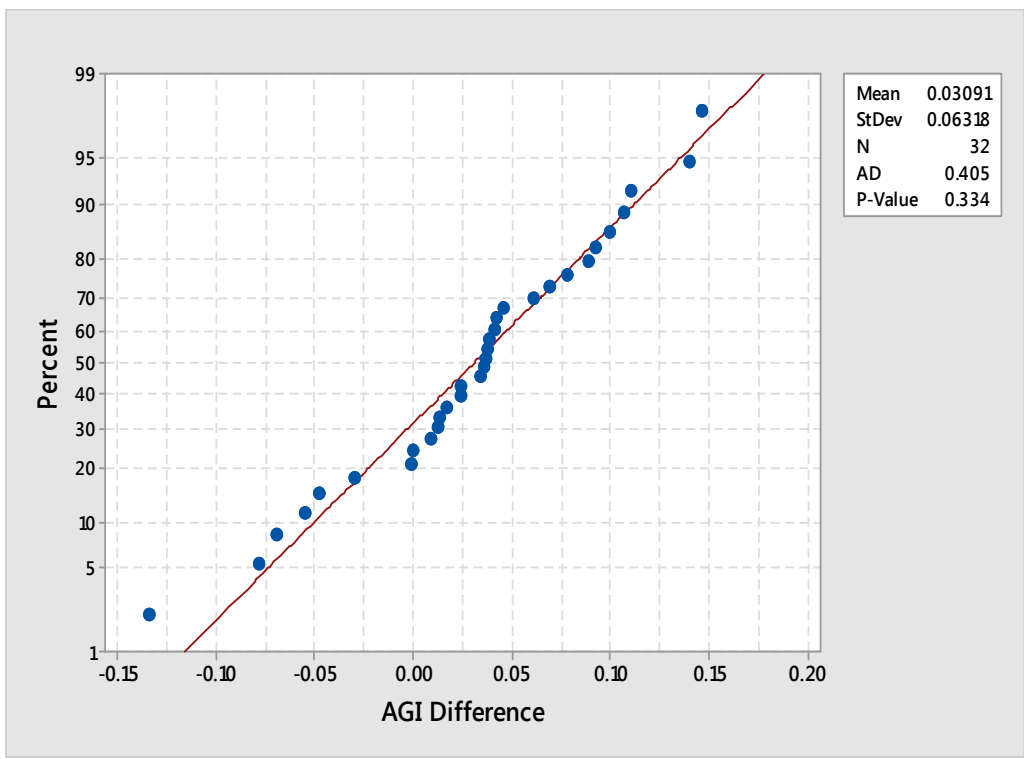




\section{Percentage Loss in Shredder when Ripened at $3.3^{\circ} \mathrm{C}(38 \mathrm{~F})$ and $8.9^{\circ} \mathrm{C}(48 \mathrm{~F})$}
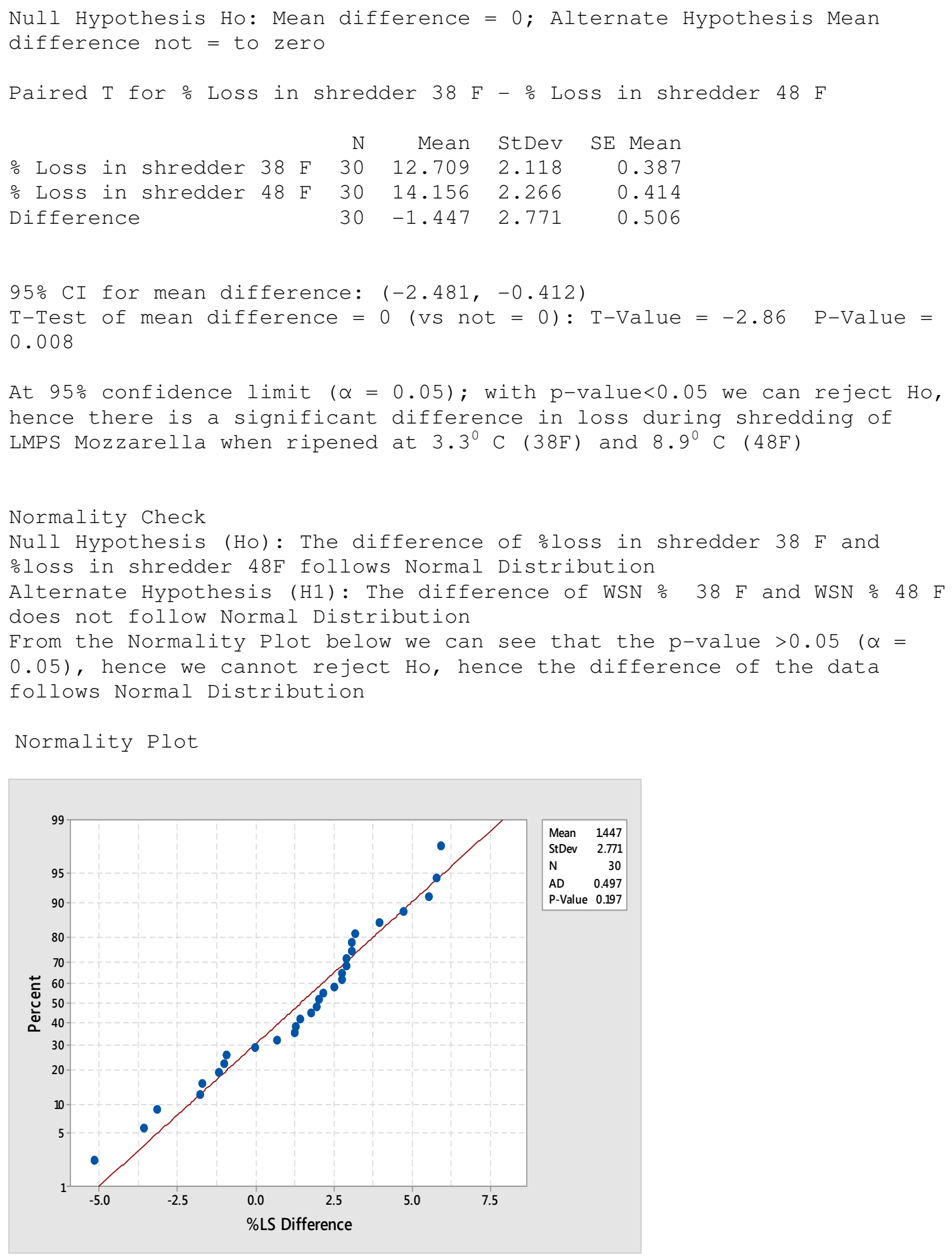
pH when Ripened at $3.3^{\circ} \mathrm{C}(38 \mathrm{~F})$ and $8.9^{\circ} \mathrm{C}(48 \mathrm{~F})$

Null Hypothesis Ho: Mean difference $=0$; Alternate Hypothesis Mean difference not $=$ to zero

$\begin{array}{lrrrrr} & \mathrm{N} & \text { Mean } & \text { StDev } & \text { SE Mean } \\ \text { pH } 38 \mathrm{~F} & 30 & 5.52656 & 0.04626 & 0.00845 \\ \text { pH } 48 \mathrm{~F} & 30 & 5.52378 & 0.04426 & 0.00808 \\ \text { Difference } & 30 & 0.00278 & 0.04027 & 0.00735\end{array}$

95\% CI for mean difference: (-0.01226, 0.01781)

$\mathrm{T}$-Test of mean difference $=0$ (vs not $=0): \mathrm{T}-$ Value $=0.38$ P-Value $=$ 0.708

At 95\% confidence limit $(\alpha=0.05)$; with p-value>0.05 we can reject Ho, hence there is no significant difference in pH of LMPS Mozzarella when ripened at $3.3^{\circ} \mathrm{C}(38 \mathrm{~F})$ and $8.9^{\circ} \mathrm{C}(48 \mathrm{~F})$

Normality Check

Null Hypothesis (Ho): The difference of oloss in shredder $38 \mathrm{~F}$ and oloss in shredder 48F follows Normal Distribution

Alternate Hypothesis (H1): The difference of WSN $\% 38$ F and WSN 48 F does not follow Normal Distribution

From the Normality Plot below we can see that the p-value $>0.05$ ( $\alpha=$ 0.05), hence we cannot reject Ho, hence the difference of the data follows Normal Distribution

Normality Plot

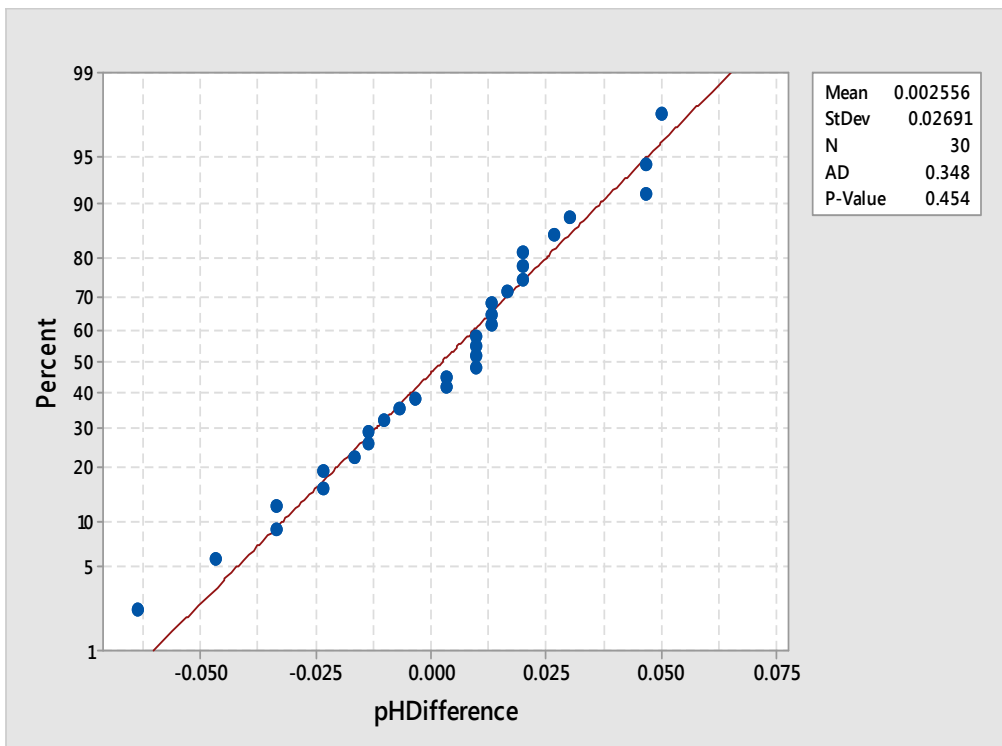

